\title{
15. LATE NEOGENE PALEOCEANOGRAPHY AND PALEOCLIMATOLOGY OF THE NORTHEAST INDIAN OCEAN (SITE 758) ${ }^{1}$
}

\author{
John W. Farrell ${ }^{2}$ and Thomas R. Janecek ${ }^{3}$
}

\begin{abstract}
The evolution of oceanic and climatic conditions the northeast Indian Ocean during the last $7 \mathrm{~m} . \mathrm{y}$. is revealed in the sediments from Site 758. We present detailed and continuous records of $\delta^{18} \mathrm{O}$ and $\delta^{13} \mathrm{C}$ from planktonic foraminifers, weight percent calcium carbonate, weight percent coarse fraction, magnetic susceptibility, and geomagnetic reversals. Sample spacing of the records ranges from 3 to $10 \mathrm{~cm}$ and is equivalent to an average time interval of 2000 to $6000 \mathrm{yr}$. Despite the fact that core recovery ranged between $100 \%$ and $105 \%$, recovery gaps as large as $2.7 \mathrm{~m}$ occurred at nearly every break between advanced hydraulic piston cores. Approximately $12 \%$ of the late Neogene sequence was not recovered in each of the two holes drilled at Site 758 . To circumvent the discontinuity introduced by the gaps, a composite depth section was constructed from multiple cores taken from offset holes at Site 758. The resulting composite depth section extends continuously from 0 to $116 \mathrm{mbsf}$, from the Holocene to the upper Miocene.

A detailed chronostratigraphy is based on geomagnetic reversals which extend from the Brunhes Chron to Chron 6 , and on $\delta^{i 8} \mathrm{O}$ stages 1 through 105 , which span from 0 to $2.5 \mathrm{Ma}$. The $\delta^{18} \mathrm{O}$ record is dominated by a $\sim 40-\mathrm{k} . \mathrm{y}$. cycle in the late Pliocene and early Pleistocene, and is followed by a change to a 100-k.y. cycle in the late Pleistocene. The mid-Pleistocene transition between these two modes of variability occurs between $\delta^{18} \mathrm{O}$ stages 25 and 22 (between 860 and $800 \mathrm{Ka}$ ). Thirteen major volcanic ash horizons from the Indonesian arc are observed throughout the sedimentary section and are dated by their relative position within the geomagnetic reversals and the $\delta^{18} \mathrm{O}$ chronostratigraphy.

Since $5 \mathrm{Ma}$, there has been a long-term decline in weight percent $\mathrm{CaCO}_{3}$ and $\mathrm{CaCO}_{3}$ mass accumulation rates, and an associated rise in non- $\mathrm{CaCO}_{3}$ mass accumulation rates. We attribute these changes to a decrease in $\mathrm{CaCO}_{3}$ productivity and an increase in terrigenous sedimentation through enhanced riverine input. Such input may be linked to rapid tectonic uplift of the Himalayas and the Tibetan Plateau via mechanisms such as the intensification of the monsoonal rains, increased fluvial erosion, and regional glaciation. The long-term increase in percent coarse fraction since $5 \mathrm{Ma}$ suggests a gradual increase in $\mathrm{CaCO}_{3}$ preservation. Higher frequency fluctuations in $\mathrm{CaCO}_{3}$ preservation are superimposed on the long-term trend and are related to climate fluctuations. The abrupt drop $(-50 \%)$ in $\mathrm{CaCO}_{3}$ accumulation at $3.4 \mathrm{Ma}$ signals a dramatic decrease in $\mathrm{CaCO}_{3}$ production that occurred over much of the Indian Ocean.
\end{abstract}

\section{INTRODUCTION}

One of the principal objectives of Ocean Drilling Program (ODP) Leg 121 was to recover a complete late Neogene sediment sequence to address fundamental questions regarding the paleoenvironment of the northeastern Indian Ocean. A continuous record of predominantly undisturbed late Neogene sediments, with moderate to high accumulation rates, is provided by the multiple advanced hydraulic piston cores (APC) from three offset holes at Site 758, atop the northern end of the Ninetyeast Ridge (Fig. 1). The geomagnetic reversal record from this site is excellent. All major magnetic events from the Brunhes Chron through Chron 6 are present, and reversal boundaries are sharp and well-defined (Shipboard Scientific Party, 1989).

The sedimentary records from Site 758 provide a rare opportunity for the simultaneous evaluation of (1) the oceanic and climatic evolution of the northeast Indian Ocean; (2) the periodic nature of climate change attributed to the Milankovitch mechanism; (3) the effects of tectonic uplift of the Himalayas and the Tibetan Plateau; and (4) the history of volcanic activity in the nearby Indonesian arc. To address these objectives, a database of long, continuous, and detailed paleoenvironmental indices must be constructed and synthesized. Our focus in this study is to

\footnotetext{
${ }^{1}$ Weissel, J., Peirce, J., Taylor, E., Alt, J., et al., 1991. Proc, ODP, Sci. Results, 121: College Station, TX (Ocean Drilling Program).

${ }^{2}$ Department of Geological Sciences, Brown University, Providence, RI 02912 1846, U.S.A.

${ }^{3}$ Ocean Drilling Program, Texas A\&M University, 1000 Discovery Drive, College Station TX 77845, U.S.A.
}

generate and provide preliminary analysis of weight percent (wt \%) $\mathrm{CaCO}_{3}$ and $\mathrm{wt} \%$ coarse fraction records spanning the last $5.2 \mathrm{~m} . \mathrm{y}$., and $\delta^{13} \mathrm{C}$ and $\delta^{18} \mathrm{O}$ records from planktonic foraminifers extending from 0 to $2.5 \mathrm{Ma}$. $\mathrm{CaCO}_{3}$ is examined because it is the dominant component and because it provides information about biological productivity in the surface ocean and $\mathrm{CaCO}_{3}$ dissolution on the seafloor. Percent coarse fraction is an independent index of $\mathrm{CaCO}_{3}$ preservation. The stable isotope record provides a chronostratigraphy and information about fluctuations in ice volume, surface water temperature, and salinity. Because preliminary investigation suggests that the sedimentary concentrations of biogenic opal and organic carbon (D. Murray, pers. comm., 1990) are low at Site 758, the terrigenous percentage of the sediment can be approximated as $100-w t \% \mathrm{CaCO}_{3}$. This estimate is slightly higher than the true percentage of terrigenous sediments. The volcanic ash at Site 758 provides a tephrochronology of Indonesian arc volcanism. A complete description of the ash layers referred to in this study by alphabetic nomenclature (e.g. "ash A"), is presented by Dehn et al. (this volume). The records generated in this study are examined in the context of geomagnetic reversal and magnetic susceptibility (MS) records of the last 7.3 m.y. By constructing a composite depth section from Holes $758 \mathrm{~A}$ and $758 \mathrm{~B}$, which splices across recovery gaps, it is possible to produce an undisturbed, continuous sedimentary section that extends from 0 to 116 meters below seafloor (mbsf) which is equivalent in time to the past $7.3 \mathrm{~m} . \mathrm{y}$.

The sediment at Site 758 is primarily biogenic pelagic $\mathrm{CaCO}_{3}$, but terrigenous silts and clays and volcanic tephra are also important components. The modern eolian contribution to the eastern equatorial Indian Ocean is negligible, as shown by the low concentration of soil (mineral) aerosol particles in the marine atmos- 


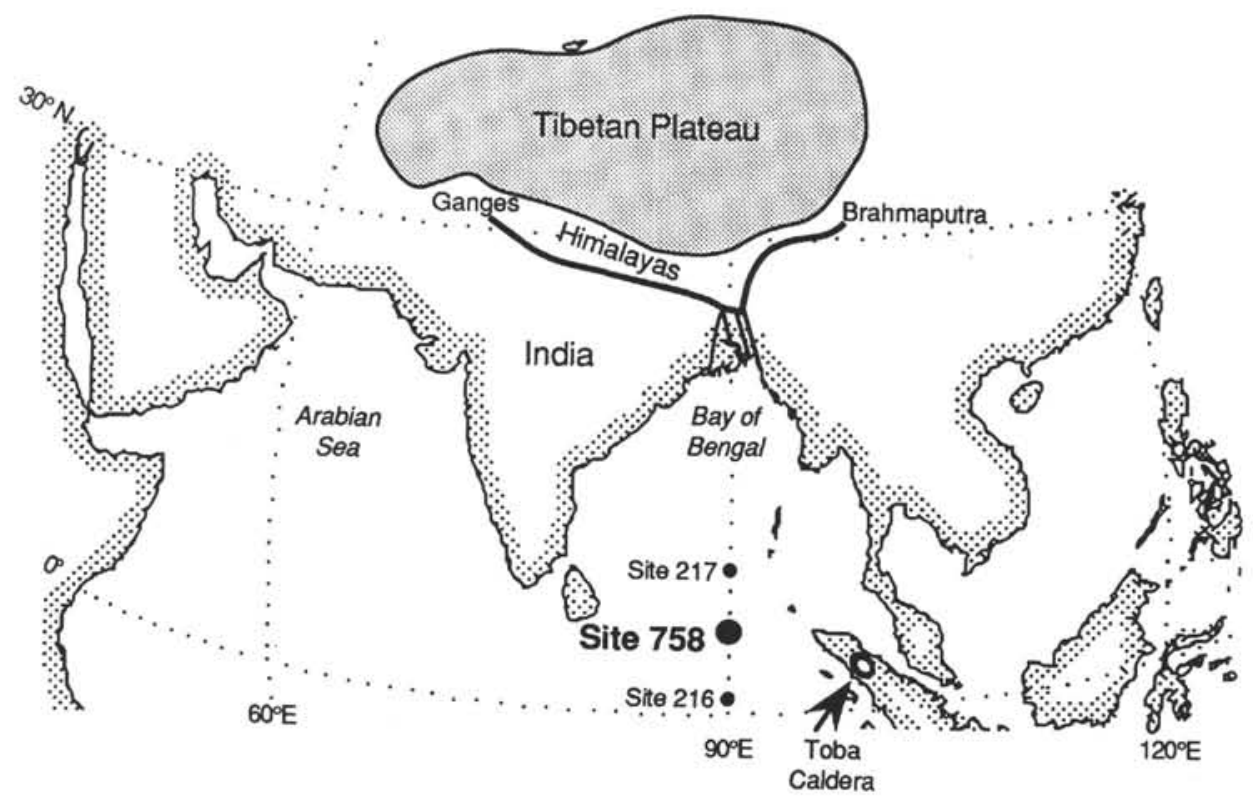

Figure 1. Location of Site 758. Also shown are DSDP Sites 216 and 217.

phere (Prospero, 1981). Rivers contribute most of the terrigenous sediment, which is predominantly allochthonous $\mathrm{Si}-\mathrm{Fe}$ smectites and illites (Bouquillon et al., 1989). The Ganges and the Brahmaputra rivers drain the Himalayas and the Indian subcontinent and contribute $1.7 \times 10^{9}$ tons of sediment to the ocean per year (Milliman and Meade, 1983), more than any other river system in the world. These sediments have built the Bengal Fan, one of the world's largest fans. Coarse-grained materials are confined to the fan but the finer silts and clays are transported to Site 758 which lies about $1000 \mathrm{~m}$ above the Bengal Fan. Silt and clay are most likely transported by turbidity currents and within nepheloid layers (Kolla et al., 1976; Stow et al., 1990).

\section{DATA AND METHODS}

Site $758\left(5^{\circ} 23^{\prime} \mathrm{N}, 90^{\circ} 21^{\prime} \mathrm{E} ; 2925 \mathrm{~m}\right.$ water depth) is on the southeast side of a large en echelon block of the Ninetyeast Ridge approximately halfway between Deep Sea Drilling Project (DSDP) Sites 216 and 217 (Fig. 1). For Site 758, we report here late Neogene records of $w t \% \mathrm{CaCO}_{3}$, wt \% coarse fraction $(>150$ $\mu \mathrm{m})$, and planktonic foraminifer $\delta^{13} \mathrm{C}$ and $\delta^{18} \mathrm{O}$. Specifically, a total of $92210-\mathrm{cm}^{3}$ samples were analyzed at $10-\mathrm{cm}$ intervals in Cores $121-758 \mathrm{~A}-1 \mathrm{H}$ through $121-758 \mathrm{~A}-8 \mathrm{H}$ ( 00.01 to $73.55 \mathrm{mbsf})$ and at $10-\mathrm{cm}$ intervals in various sections within Hole $758 \mathrm{~B}$. These records are compared to shipboard wt $\% \mathrm{CaCO}_{3}$ data and to records of the whole-core volume MS and geomagnetic reversals. All records are displayed as a composite depth section (see below) based primarily on samples from Hole $758 \mathrm{~A}$ and secondarily on samples from Hole 758B.

\section{Sample Preparation}

All samples were subsampled, retaining approximately $1 \mathrm{~cm}^{3}$ for $w t \% \mathrm{CaCO}_{3}$ analysis. The remainder of the sample was freeze-dried, weighed, diggregated in tap water, wet-sieved through a $150-\mu \mathrm{m}$ sieve, and dried at $50^{\circ} \mathrm{C}$. Percent coarse fraction is the weight percentage of the sample $>150 \mu \mathrm{m}$. The fine fraction $(<150 \mu \mathrm{m})$ was allowed to settle for $24 \mathrm{hr}$, the water siphoned off to within about $1 \mathrm{~cm}$ of the sediment-water interface, and the fine residue dried, weighed, and saved for future studies. The coarse fraction $(>150 \mu \mathrm{m})$ was divided into two aliquots, one for faunal analysis and the other for stable isotope analysis. Seven samples (identified in Appendix F) consisting primarily of volcanic ash were subsampled and analyzed for wt $\% \mathrm{CaCO}_{3}$ only, the remainder was not processed further.

\section{$\mathrm{Wt} \% \mathrm{CaCO}_{3}$ Analysis}

The wt $\% \mathrm{CaCO}_{3}$ of the bulk dry sediment was determined on the Brown University $\mathrm{CaCO}_{3}$ system. This is a modified version of the Jones and Kaiteris (1983) gasometric technique with a differential pressure gauge used in place of a vacuum gauge and with carbonate reactions measured at atmospheric pressure. Replicate analyses of both samples and standards give an analytical precision better than $1 \%$ by weight.

To determine whether the results of shipboard wt $\% \mathrm{CaCO}_{3}$ analyses were similar to those obtained in this study, such that the two databases could be combined without offset in future studies, we analyzed aliquots of 38 shipboard samples that had been measured for both wt $\% \mathrm{CaCO}_{3}$ and physical properties. Shipboard wt $\% \mathrm{CaCO}_{3}$ analyses were made on a Coulometrics 5010 Coulometer coupled with the 5030 Carbonate Carboñ apparatus described elsewhere (Peirce, Weissel, et al. 1989). Our analyses of the shipboard samples show that the results of the two laboratories are nearly identical (Appendix A, Fig. 2). On average, the shipboard wt $\% \mathrm{CaCO}_{3}$ data are only $1 \%$ greater than our data. Because this difference is well within the combined analytical precision of the two laboratories, no adjustments to either database are required before merging the two.

\section{Stable Isotope Analysis}

The $\delta^{13} \mathrm{C}$ and $\delta^{18} \mathrm{O}$ of planktonic foraminifers were measured in the Brown University Benedum Stable Isotope Laboratory on 6 to 15 individuals of Globigerinoides sacculifera, predominantly without sacs, and picked from the 300 - to $355-\mathrm{mm}$ size range. The restricted size range and preference of specimens without sacs minimizes the noise from ontogenetic variation on the isotopic composition (Berger et al., 1978; Curry and Matthews, 1981). Since we observed no large difference in the isotopic composition of G. sacculifera with sacs vs. those without, all were included when calculating the mean isotopic value for a given sample depth.

Picked foraminifer samples were cleaned ultrasonically for about $10 \mathrm{~s}$ to remove adhering fine-grained material. Dry samples were transferred into stainless steel boats filled with ethyl alcohol. 


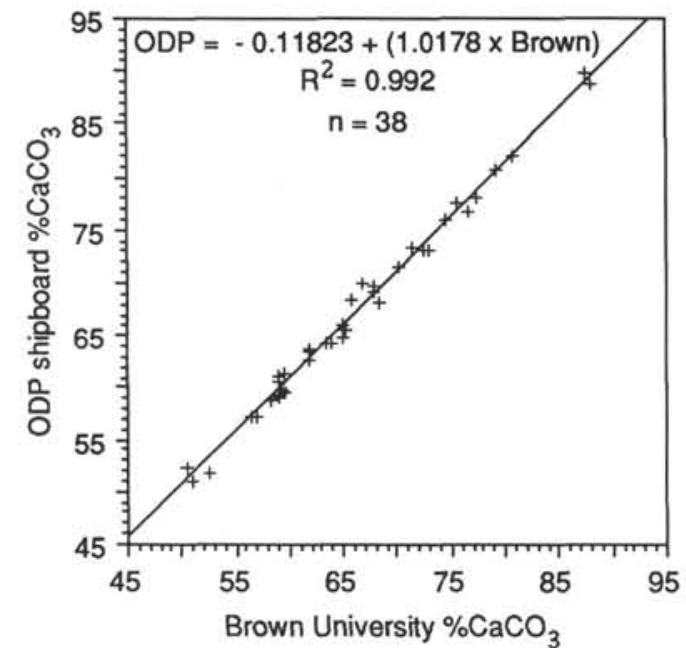

Figure 2. Comparison of $w t \% \mathrm{CaCO}_{3}$ data from the Brown University and the ODP shipboard laboratories. Although ODP values average $1 \%$ greater than those from Brown, the difference is insignificant given the combined precision of the two laboratories.

The alcohol facilitates the transfer to the boats and prevents sample loss. The samples were crushed with a glass pestle to prevent sample loss and to enhance the reaction with the acid. The boats were placed in a drying oven at $75^{\circ} \mathrm{C}$ for at least one hr. Dry samples were roasted in vacuo at $300^{\circ} \mathrm{C}$ for $1 \mathrm{hr}$ to remove possible organic contaminants. The samples were then either analyzed or returned to the drying oven. In the extraction line, each $\mathrm{CaCO}_{3}$ sample was reacted with phosphoric acid at $90^{\circ} \mathrm{C}$ for $14 \mathrm{~min}$. During this reaction, water and carbon dioxide were extracted by continuous trapping with liquid nitrogen. The carbon dioxide was analyzed on a fully automated online VG Sira 24 Micromass mass spectrometer. Isotopic composition is expressed as a deviation per mil from the Pee Dee belemnite (PDB) standard (Craig, 1957).

The Benedum Stable Isotope Laboratory's mass spectrometry reference gas (BIG-5) is calibrated to PDB by analysis of National Bureau of Standards (NBS) 19 and 20. The Benedum Laboratory values for NBS-19 are $-2.09 \%\left(\delta^{18} \mathrm{O}\right)$ and $1.88 \% o\left(\delta^{13} \mathrm{C}\right)$, which compares to values reported by the NBS (I. L. Barnes, pers. comm., 1985$)$ of $-2.19 \%$ o $\left(\delta^{18} \mathrm{O}\right)$ and $1.92 \%\left(\delta^{13} \mathrm{C}\right)$. The Benedum Laboratory values for NBS-20 are $-4.20 \%\left(\delta^{18} \mathrm{O}\right)$ and $-1.04 \%$ o $\left(\delta^{13} \mathrm{C}\right)$, which compares to NBS values of $-4.14 \%$ $\left(\delta^{18} \mathrm{O}\right)$ and $-1.06 \%$ \%o $\left(8^{13} \mathrm{C}\right)$ (I. L. Barnes, pers. comm., 1985).

Analytical precision $(1 \sigma)$, indicated by the first acceptable analysis of the in-house working carbonate standard (BP-4) before each analytical session (36 days), is $\pm 0.07 \%$ for oxygen and $\pm 0.05 \%$ for carbon. Analytical precision ( $1 \sigma$ ) based on 359 duplicate analyses, almost always run on separate days, is $\pm 0.09 \%$ for oxygen and $\pm 0.08 \%$ for carbon.

\section{Dry-Bulk Density Estimates}

Dry-bulk density values, which are required to calculate mass accumulation rates (MAR), were estimated from shipboard data. The data consists of wet-bulk density estimates from gamma-ray attenuation (GRAPE) data measured at an average interval of 1.8 $\mathrm{cm}$, and discrete wet-bulk density (WBD) and dry-bulk density (DBD) values (table 18, pp. 425-426 in Pierce, Weissel, et al., 1989) measured at an average interval of $80 \mathrm{~cm}$ in the APC cores from Holes 758A and 758B. The GRAPE WBD estimates from
Hole 758A were smoothed with a 3-point Gaussian filter and were sampled at depths corresponding to the discrete WBD and DBD measurements using a linear interpolation between adjacent measurements. A linear regression of the resulting GRAPE WBD and the discrete WBD,

$$
\begin{gathered}
\text { discrete WBD }=0.077+(0.924 \cdot \text { GRAPE WBD }), \\
r^{2}=0.87, n=130,
\end{gathered}
$$

was used to transform GRAPE values into discrete WBD estimates. The transformed WBD estimates were then converted to DBD estimates by the linear regression of the discrete WBD against the discrete DBD:

$$
\begin{aligned}
\text { discrete } \mathrm{DBD}= & -1.570+(1.541 \cdot \text { discrete WBD }), \\
& r^{2}=0.98, n=130 .
\end{aligned}
$$

With these relationships established, the smoothed GRAPE values were sampled at depths corresponding to samples used in our study by linear interpolation. Where GRAPE data were not available for intervals in Hole 758A (as for section 7 and corecatcher samples from every core), the GRAPE data from the equivalent section (based on the correlation of MS records) from Hole $758 \mathrm{~B}$ were substituted. The dry-bulk density estimates (in units of grams of dry sediment per wet volume, in $\mathrm{cm}^{3}$ ) are listed in Appendixes B and C.

\section{Mass Accumulation Rates}

MAR is the mass of a sedimentary material preserved per unit area and unit of time, commonly expressed in units of grams, per square centimeter, per $1000 \mathrm{yr}\left(\mathrm{g} / \mathrm{cm}^{2} / \mathrm{k}\right.$.y.). MAR can be thought of as either the flux of material onto a substrate, or the flux across the water/sediment interface. We calculated the MAR of $\mathrm{CaCO}_{3}$ from the linear sedimentation rate (LSR, in m/m.y.), the DBD (in $\mathrm{g} / \mathrm{cm}^{3}$ ), and the $\mathrm{wt} \% \mathrm{CaCO}_{3} \cdot \mathrm{CaCO}_{3} \mathrm{MAR}$ was calculated as:

$$
\begin{gathered}
\mathrm{CaCO}_{3} \operatorname{MAR}\left(\mathrm{g} / \mathrm{cm}^{2} / \mathrm{k} . \mathrm{y} .\right)=\left[\mathrm{LSR}(\mathrm{m} / \mathrm{m} . \mathrm{y} .) \cdot \mathrm{DBD}\left(\mathrm{g} / \mathrm{cm}^{3}\right) \cdot w \mathrm{t} \%\right. \\
\left.\mathrm{CaCO}_{3}\right] / 1000 .
\end{gathered}
$$

It is worth stressing that MAR estimates are only as accurate and detailed as the chronostratigraphy upon which they are based. This stems from the fact that the magnitude of the variations in $\mathrm{CaCO}_{3} \mathrm{MAR}$ at Site 758 are strongly controlled by LSR changes, and less so by changes in wt $\mathrm{CaCO}_{3}$ and DBD. In absolute values, the variations in LSR are almost always greater than those in $w t \% \mathrm{CaCO}_{3}$ and DBD. A detailed chronostratigraphy from an $\delta^{18} \mathrm{O}$ record will enable us to determine LSR changes, and thus $\mathrm{CaCO}_{3} \mathrm{MAR}$ changes on the order of $10^{4} \mathrm{yr}$. A chronostratigraphy based on linear interpolation between age estimates separated by a long time interval, such as between the sediment/water interface and the Brunhes/Matuyama geomagnetic reversal, cannot resolve high-frequency fluctuations in LSR. As a result, $\mathrm{CaCO}_{3} \mathrm{MAR}$ variations based on a low-resolution chronostratigraphy are controlled by variations in wt $\mathrm{CaCO}_{3}$ and $\mathrm{DBD}$, which do not necessarily reveal the dynamics of oceanographic change at high frequencies.

\section{Magnetic Susceptibility and Declination Data}

Shipboard MS provides the fundamental lithostratigraphy for this study. The MS data shown in Figure 3 (back pocket) were measured at 3- to 5-cm intervals. Measurements of whole-core low-field MS are rapid, simple, and nondestructive. MS is gaining recognition as an invaluable lithostratigraphy in a variety of 
sedimentary regimes (see Robinson, 1990, for an excellent review of MS methodology and application). MS is primarily a measure of the concentration (per unit volume) of magnetizable material such as the ferromagnetic minerals and paramagnetic materials including clays (smectite, in particular). In the absence of complicating factors, such as suboxic diagenesis and rust flakes in the core pipes, MS variations in pelagic sediments primarily reflect the ratio of biogenic to lithogenic components (Thompson and Oldfield, 1986; Robinson, 1990; deMenocal and Bloemendal, 1990). A significant exception to this generalization is mafic volcanic ash. At Site 758 , the ferromagnetic minerals, such as titanomagnetite, in some ash layers are easily identified by the extremely high $\left(\sim 100 \cdot 10^{-6} \mathrm{cgs}\right)$ MS values. The MS values in ash-free sediments from Site 758 range between 0 and $\sim 20 \cdot 10^{-6}$ cgs. The high-resolution MS records are used in this study (1) to construct detailed lithostratigraphic correlations among the holes; (2) to identify sediments disturbed by the coring process; (3) to determine coring gaps of unrecovered sediment; (4) to identify volcanic ash layers; and (5) to construct a composite depth section for the past $7.3 \mathrm{~m} . y$. Future work will help establish the degree to which the MS data can be used to interpret paleoceanographic and paleoclimatic conditions at Site 758. MS values corresponding to the sample depths in our composite record are listed in Appendix F. These values were obtained by linear interpolation of adjacent shipboard MS values.

Magnetic declination data and the interpreted geomagnetic reversal stratigraphy are shown along with the raw shipboard MS data in Figure 3 (back pocket). The magnetic reversal record is the primary chronostratigraphy for this study. The natural remanent magnetization of whole-round sections of all APC cores from Holes $758 \mathrm{~A}$ and $758 \mathrm{~B}$ was measured at $10-\mathrm{cm}$ (and occasionally $5-\mathrm{cm}$ ) intervals using the shipboard cryogenic magnetometer (Pierce, Weissel, et al., 1989). The resulting declination-based magnetostratigraphies are of exceptionally high quality. The magnetic reversal boundaries are generally sharp and well-defined. All chrons and subchrons (except perhaps the two Reunion Subchrons) from the Brunhes Chron to Chron 6 were recovered in Hole 758A and/or Hole 758B.

\section{COMPOSITE DEPTH SECTION}

Because our objectives include detailed examination of a highresolution sedimentary section and, eventually, time-series analysis, continuity of the records from Site 758 is critical. With considerable effort, we have constructed a continuous depth section for Site 758 and ensured its continuity with several independent stratigraphies.

At Site 758 , three holes were drilled within $26 \mathrm{~m}$ of each other to recover the late Neogene sedimentary sequence. The cores from Holes $758 \mathrm{~A}$ and $758 \mathrm{~B}$ were drilled at staggered depths in order to overlap core breaks. Although APC core recovery was excellent, ranging from $100 \%$ to $105 \%$, interhole correlation of the highresolution MS and other stratigraphies shows sediment recovery gaps as large as $2.7 \mathrm{~m}$ at nearly every core break (Fig. 3, back pocket) (table 12, pp. 416-417, in Shipboard Scientific Party, 1989). An average of $1 \mathrm{~m}$ of sediment is missing between each successive APC core in Holes 758 A and 758B. This suggests that $12 \%$ of the APC-cored sequence was not recovered in each hole. This percentage translates into about $13 \mathrm{~m}$ of unrecovered sediment in the top 110 mbsf. Similar occurrences of missing sediment at APC core breaks have been reported for several DSDP/ODP legs, including Leg 94 (Ruddiman et al., 1987; Ruddiman et al., 1989; Raymo et al., 1989), Leg 111 (Alexandrovich and Hays, 1989), Leg 115 (Robinson, 1990), and Leg 117 (deMenocal and Bloemendal, 1991; Murray and Prell, 1991). Precise identification of the sediment gaps, unaccounted for by the normal process of sub-bottom depth assignment, would have been impossible had Site 758 not been double-cored and measured for magnetic susceptibility.

Analysis of the sedimentary sequence at Site 758 was complicated by these gaps. To circumvent this problem, a composite section for Site 758 was constructed by splicing the missing sedimentary intervals at the core breaks in Hole 758 A with the equivalent intervals from Hole 758B. Identification of equivalent intervals was based on interhole correlation of MS and geomagnetic reversals. These intervals were independently verified by stratigraphic correlation of $\mathrm{wt} \% \mathrm{CaCO}_{3}$, wt $\%$ coarse fraction, and $\delta^{18} \mathrm{O}$ records where possible. An example is shown in Figure 4. The splices are accurate to within 3 to $10 \mathrm{~cm}$ (the respective sample spacing of the MS and other stratigraphies), which is equivalent to an average time interval of 2 to $6 \mathrm{k}$.y. Sub-bottom depths were calculated for the composite section by assigning the sediment-water interface a depth of $0.00 \mathrm{~m}$ and progressively adding the length of each successive Hole 758 A interval and Hole $758 \mathrm{~B}$ splice down through the sedimentary sequence (Table 1). The addition of the splices results in composite depths which grow progressively deeper than the depths assigned by the nominal ODP method, which does not recognize, and therefore account for, the gaps. For example, Section 121-758A-11H-7, at $65 \mathrm{~cm}$, has a composite depth of 116.19 mbsf, which is $13.74 \mathrm{~m}$ greater than the ODP depth of $102.45 \mathrm{mbsf}$. This implies that shipboard sub-bottom depths are too shallow (e.g., $\sim 14 \mathrm{~m}$ at the bottom of Core $121-758 \mathrm{~A}-11 \mathrm{H}$, more than the length of an entire drill pipe). The apparent discrepancy between shipboard sub-bottom depths and those assigned here could be resolved if distinct lithostratigraphic markers in the recovered cores are correlated to the downhole logging results. Preliminary attempts to correlate the cores to the logs have proven unsuccessful. This is attributed to the fact that the top $42 \mathrm{~m}$ of Hole $758 \mathrm{~A}$ were logged through the drill string such that the distinct ash layers in the cores could not be identified in the logs. Improvements in the resolution of logging tools will undoubtedly aid in future attempts to correlate cores and logs.

Why is sediment missing at the core breaks and why is it missing if core recovery exceeded $100 \%$ ? In a review of sediment disturbance due to the coring process, Ruddiman et al. (1987) examined several ways in which "under-recovery" of sediment can occur. The most likely explanation for the gaps between cores at Site 758 involves sediment loss, accompanied by expansion and/or stretching of sediment. Sediment loss may occur in the drill hole due to ship heave. APC-coring is not heave-compensated. Heave of the ship, even in calm seas, can easily move the drill string up and down by a meter or two. Downheaval of the drill string between the times when cores are taken would disturb or displace an interval of the sedimentary sequence. If this occurred, the top of the interval recovered by the subsequent core would be deeper in the sedimentary sequence than anticipated. The uppermost sediments intended for recovery would have been pushed aside and not recovered. Since under-recovery occurred at almost every core break, it would appear that downheaval and sediment displacement occurred before every core was taken. However, it seems unlikely that the ship consistently heaved downward before each APC core was taken. The chances of upheaval just prior to APC-coring are just as likely as downheaval.

Upheaval of the ship just before shooting the APC would result in the retrieval of a short sedimentary section with an interval of water at the top. The uppermost sediments in such a core could be disturbed by sloshing of the water during core retrieval or they could absorb the water resulting in core expansion and a decrease in bulk density. This may explain why low GRAPE values are 

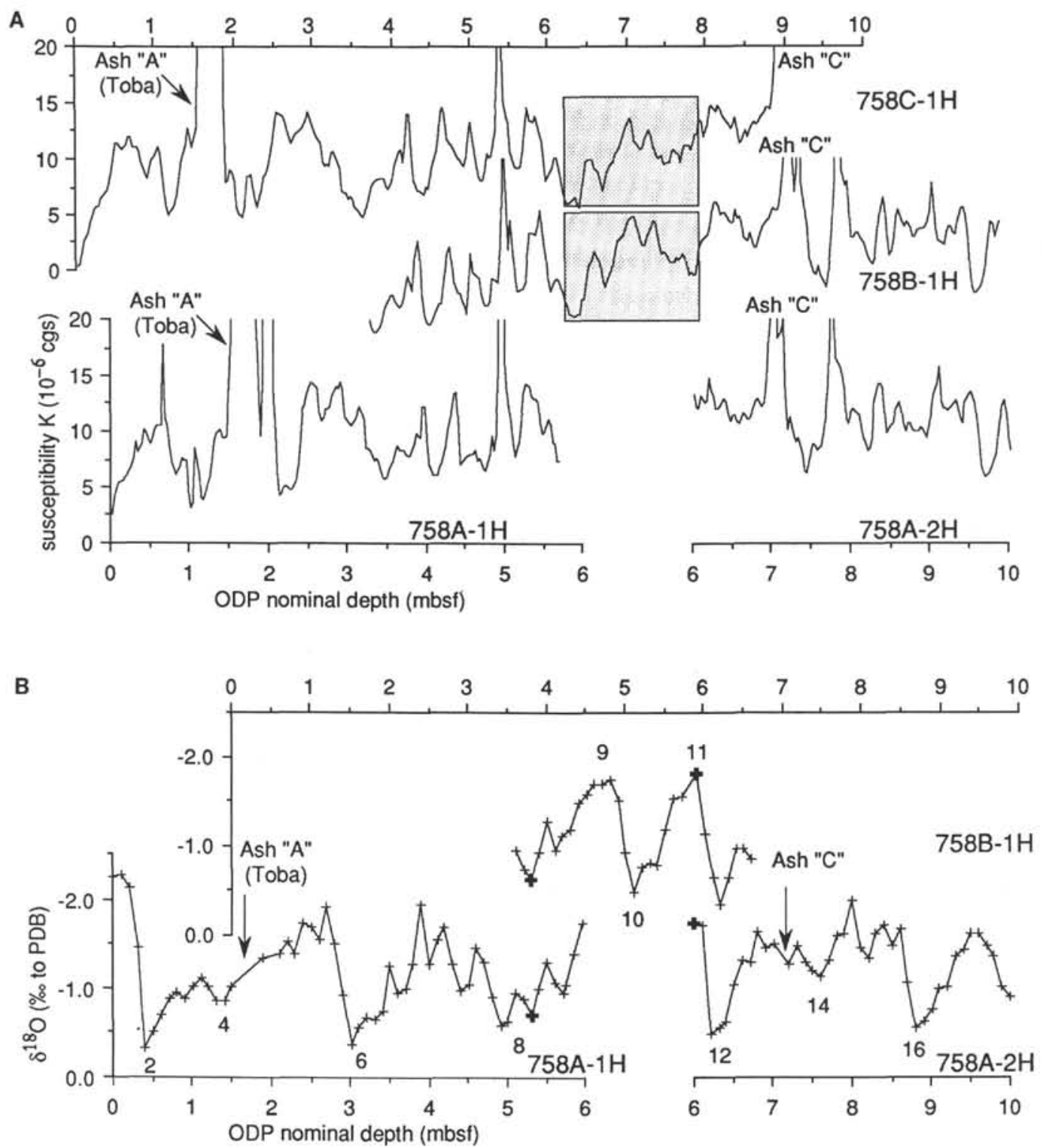

Figure 4. Example of a recovery gap and splices based on magnetic susceptibility and $\delta^{18} \mathrm{O}$ records. A. High-resolution (3-cm interval) magnetic susceptibility records show a recovery gap at the break between Cores 121-758 A-1H and 121-758 A-2H and a core splice (shaded region) from both Cores $121-758 \mathrm{~B}-1 \mathrm{H}$ and $121-758 \mathrm{C}-1 \mathrm{H}$ to fill the approximately $1.36-\mathrm{m}$ gap. B. Core splice from Core $121-758 \mathrm{~B}-1 \mathrm{H}$ demonstrates that half of interglacial $\delta^{18} \mathrm{O}$ stages 9 and 11 and the entire glacial stage 10 (nearly $100 \mathrm{k} . y$. .) were lost in the break between Cores 121-758A-1H and 121-758A-2H despite core recovery of between $102 \%$ to $104 \%$. Heavy crosses identify the tie points used to splice between holes in the construction of the composite depth section.

often observed at the tops of cores. Nevertheless, under-recovery due to upheaval seems unlikely because the core tops of almost every APC core from Site 758 appear pristine, and because the GRAPE values in the tops of cores from Site 758 were not anomalously low.

Lateral drift of the ship may also result in under-recovery (Ruddiman et al., 1987). Drift toward the positioning beacon would bury the drill pipe down into the sediment prior to APC coring. The sediments intended for recovery would be displaced by the drill string and the core actually retrieved would be from a sub-bottom depth interval deeper than expected. The dynamic positioning system of the JOIDES Resolution is much improved over that of the Glomar Challenger. Nevertheless, some drift occurs and it may contribute to under-recovery. Dynamic positioning of the Resolution apparently keeps the ship at a surface location within $2 \%$ of the water depth. If this is true, then in 2925 $\mathrm{m}$ of water (the depth of Site 758) $0.6 \mathrm{~m}$ of sediment at Site 758 could have been displaced by one drift of the ship toward the beacon. Drift toward the beacon during the shooting of all 22 APC cores at Site 758 is highly unlikely. Drift away from the beacon would result in recovery of less than $100 \%$.

Expansion and stretching of the sedimentary section can occur in several ways. A minor amount of sediment expansion may result from the decrease in hydrostatic pressure during retrieval of the core from the seafloor to the sea surface. The relatively high silt and clay content of the sediments ( $15 \%$ to $45 \%)$ may have 
Table 1. Composite depth section for Site 758.

\begin{tabular}{|c|c|c|c|c|c|c|}
\hline \multirow[b]{2}{*}{ Hole } & \multicolumn{2}{|c|}{$\begin{array}{l}\text { Core, section, } \\
\text { interval }(\mathrm{cm})\end{array}$} & \multicolumn{2}{|c|}{$\begin{array}{l}\text { ODP Depth } \\
\text { (mbsf) }\end{array}$} & \multicolumn{2}{|c|}{$\begin{array}{l}\text { Composite depth } \\
\text { (m) }\end{array}$} \\
\hline & Top & Bottom & Top & Bottom & Top & Bottom \\
\hline $758 \mathrm{~A}$ & $1 \mathrm{H}-1,1$ & $1 \mathrm{H}-4,8 \mathrm{I}$ & .00 & 5.31 & .00 & 5.31 \\
\hline $758 \mathrm{~B}$ & $1 \mathrm{H}-3,81$ & $1 \mathrm{H}-4,141$ & 3.81 & 5.91 & 5.32 & 7.42 \\
\hline $758 \mathrm{~A}$ & $2 \mathrm{H}-1,01$ & $2 \mathrm{H}-\mathrm{CC}, 1$ & 6.01 & 15.78 & 7.43 & 17.20 \\
\hline $758 \mathrm{~B}$ & $2 \mathrm{H}-5,21$ & $2 \mathrm{H}-5,71$ & 15.71 & 16.21 & 17.21 & 17.71 \\
\hline $758 \mathrm{~A}$ & $3 \mathrm{H}-1,21$ & $3 \mathrm{H}-7,61$ & 15.81 & 25.21 & 17.72 & 27.12 \\
\hline $758 \mathrm{~B}$ & $3 \mathrm{H}-3,141$ & $3 \mathrm{H}-5,81$ & 23.31 & 25.71 & 27.13 & 29.53 \\
\hline $758 \mathrm{~A}$ & $4 \mathrm{H}-1,01$ & $4 \mathrm{H}-7,71$ & 25.21 & 34.91 & 29.54 & 39.24 \\
\hline $758 \mathrm{~B}$ & $4 \mathrm{H}-5,101$ & $4 \mathrm{H}-6,41$ & 35.41 & 36.31 & 39.25 & 40.15 \\
\hline $758 \mathrm{~A}$ & $5 \mathrm{H}-1,21$ & $5 \mathrm{H}-7,51$ & 35.01 & 44.31 & 40.16 & 49.46 \\
\hline $758 \mathrm{~B}$ & $5 \mathrm{H}-4,131$ & $5 \mathrm{H}-6,91$ & 43.81 & 46.41 & 49.47 & 52.07 \\
\hline $758 \mathrm{~A}$ & $6 \mathrm{H}-1,31$ & $6 \mathrm{H}-7,71$ & 44.71 & 54.11 & 52.08 & 61.48 \\
\hline $758 \mathrm{~B}$ & $6 \mathrm{H}-4,61$ & $6 \mathrm{H}-5,81$ & 52.81 & 54.51 & 61.49 & 63.19 \\
\hline $758 \mathrm{~A}$ & $7 \mathrm{H}-1,01$ & $7 \mathrm{H}-7,61$ & 54.01 & 63.61 & 63.20 & 72.80 \\
\hline $758 \mathrm{~B}$ & $7 \mathrm{H}-4,121$ & $7 \mathrm{H}-5,91$ & 63.01 & 64.21 & 72.81 & 74.01 \\
\hline $758 \mathrm{~A}$ & $8 \mathrm{H}-1,01$ & $8 \mathrm{H}-7,41$ & 63.71 & 73.11 & 74.02 & 83.42 \\
\hline $758 \mathrm{~B}$ & $8 \mathrm{H}-5,11$ & $8 \mathrm{H}-5,8 \mathrm{I}$ & 73.11 & 73.81 & 83.43 & 84.13 \\
\hline $758 \mathrm{~A}$ & $9 \mathrm{H}-1,11$ & $9 \mathrm{H}-7,63$ & 73.51 & 83.03 & 84.14 & 93.66 \\
\hline $758 \mathrm{~B}$ & $9 \mathrm{H}-4,138$ & $9 \mathrm{H}-6,90$ & 82.58 & 85.10 & 93.67 & 96.19 \\
\hline $758 \mathrm{~A}$ & $10 \mathrm{H}-1,84$ & $10 \mathrm{H}-7,63$ & 83.94 & 92.73 & 96.20 & 104.99 \\
\hline $758 \mathrm{~B}$ & $10 \mathrm{H}-4,78$ & $10 \mathrm{H}-5,96$ & 91.58 & 93.26 & 105.00 & 106.68 \\
\hline $758 \mathrm{~A}$ & $11 \mathrm{H}-1,15$ & $11 \mathrm{H}-7,65$ & 92.95 & 102.45 & 106.60 & 116.19 \\
\hline
\end{tabular}

contributed to sediment expansion. The sediments did not contain gas which would have led to sediment expansion. No propane was found, ethane was observed in only one sample, and the concentration of methane never exceeded 9 ppm (Shipboard Scientific Party, 1989). Shipboard handling of the core may be responsible for stretching the sediments. During the extraction of the core from the core barrel and during the transfer of the core from the rig floor to the catwalk, the core liner and the sedimentary section within may stretch. The stretching could produce a sedimentary section that is longer than the section which was cored in situ, i.e., at the seafloor. Post-coring expansion/stretching from one or more of these processes probably accounts for core recovery exceeding $100 \%$ and helps explain some portion of the sub-bottom depth discrepancy between the composite depth section and the standard ODP section.

In summary, a composite depth section was constructed for Site 758 because the detailed lithostratigraphy from MS documents sediment recovery gaps between nearly every APC core in Holes $758 \mathrm{~A}$ and $758 \mathrm{~B}$. The exact cause of the gaps remains unclear but is definitely related to the drilling process. At present, the best explanation for the gaps is downheaval of the ship, which displaces a portion of the sedimentary section, and post-coring expansion/stretching of the sedimentary section which results in core recovery that exceeds $100 \%$.

\section{TIME SCALE AND SEDIMENTATION RATES}

The primary chronostratigraphy for this study is provided by the 25 chron and subchron boundaries in the geomagnetic reversal record of the past $7 \mathrm{~m}$.y. at Site 758 . The magnetic reversals are assigned the ages of Berggren et al. (1985). The magnetic reversals in the composite depth section (Table 2) were taken directly from the particular interval in Hole 758A or splice from Hole $758 \mathrm{~B}$ used to construct the composite. Linear sedimentation rates were calculated for each interval between paleomagnetic datums and are listed in Table 2 . Instantaneous sedimentation rates were calculated for each sample in the Site 758 composite record (Appendix F). The average sedimentation rate over the entire composite section is $1.6 \mathrm{~cm} / \mathrm{k} . \mathrm{y}$. This rate is equivalent to an average sample spacing of $2 \mathrm{k} . \mathrm{y}$. in the shipboard MS database and a spacing of $6 \mathrm{k} . \mathrm{y}$. in our wt $\% \mathrm{CaCO}_{3}$, wt $\%$ coarse fraction, and stable isotope database.
Table 2. Depths and ages of chron and subchron boundaries and linear sedimentation rates in the Site 758 composite depth section.

\begin{tabular}{|c|c|c|c|c|}
\hline Hole & $\begin{array}{c}\text { Composite } \\
\text { depth } \\
\text { (m) }\end{array}$ & $\begin{array}{l}\text { Age } \\
\text { (Ma) }\end{array}$ & Time zone & $\begin{array}{c}\text { Linear } \\
\text { sedimentation } \\
\text { rate } \\
(\mathrm{cm} / \mathrm{k} . \mathbf{y} .)\end{array}$ \\
\hline $758 \mathrm{~A}$ & 0.00 & 0.00 & (core top) & \\
\hline $758 \mathrm{~A}$ & 12.17 & 0.73 & Brunhes/Matuyama & 1.67 \\
\hline $758 \mathrm{~A}$ & 15.57 & 0.91 & Jaramillo (upper) & 1.89 \\
\hline $758 \mathrm{~A}$ & 16.77 & 0.98 & Jaramillo (lower) & 1.71 \\
\hline $758 \mathrm{~B}$ & 28.07 & 1.66 & Olduvai (upper) & 1.66 \\
\hline $758 \mathrm{~A}$ & 30.33 & 1.88 & Olduvai (lower) & 1.03 \\
\hline $758 \mathrm{~A}$ & 38.53 & 2.47 & Matuyama/Gauss & 1.39 \\
\hline $758 \mathrm{~A}$ & 44.65 & 2.92 & Kaena (upper) & 1.36 \\
\hline $758 \mathrm{~A}$ & 45.65 & 2.99 & Kaena (lower) & 1.43 \\
\hline $758 \mathrm{~A}$ & 47.05 & 3.08 & Mammoth (upper) & 1.56 \\
\hline $758 \mathrm{~A}$ & 48.10 & 3.18 & Mammoth (lower) & 1.05 \\
\hline $758 \mathrm{~B}$ & 51.31 & 3.40 & Gauss/Gilbert & 1.46 \\
\hline $758 \mathrm{~B}$ & 61.63 & 3.88 & Cochiti (upper) & 2.15 \\
\hline $758 \mathrm{~A}$ & 63.24 & 3.97 & Cochiti (lower) & 1.79 \\
\hline $758 \mathrm{~A}$ & 65.39 & 4.10 & Nunivak (upper) & 1.65 \\
\hline $758 \mathrm{~A}$ & 67.84 & 4.24 & Nunivak (lower) & 1.75 \\
\hline $758 \mathrm{~A}$ & 70.69 & 4.40 & Sidufjall (upper) & 1.78 \\
\hline $758 \mathrm{~A}$ & 72.24 & 4.47 & Sidufjall (lower) & 2.21 \\
\hline $758 \mathrm{~B}$ & 73.00 & 4.57 & Thvera (upper) & 0.76 \\
\hline $758 \mathrm{~A}$ & 77.11 & 4.77 & Thvera (lower) & 2.06 \\
\hline $758 \mathrm{~A}$ & 86.98 & 5.35 & Gilbert/Chron 5 & 1.70 \\
\hline $758 \mathrm{~A}$ & 91.08 & 5.53 & Chron 5 event 1 (upper) & 2.28 \\
\hline $758 \mathrm{~A}$ & 93.28 & 5.68 & Chron 5 event 1 (lower) & 1.47 \\
\hline $758 \mathrm{~A}$ & 96.61 & 5.89 & Chron $5 /$ Chron 6 & 1.59 \\
\hline $758 \mathrm{~A}$ & 102.41 & 6.37 & Chron 6 event 1 (upper) & 1.21 \\
\hline $758 \mathrm{~A}$ & 104.31 & 6.50 & Chron 6 event 1 (lower) & 1.46 \\
\hline
\end{tabular}

Note: Ages are from Berggren et al. (1985).

Sedimentation rates over last 7.3 m.y. can be divided into four general intervals: (1) 6.50 to $5.89 \mathrm{Ma}$, (2) 5.89 to $3.40 \mathrm{Ma}$, (3) 3.40 to $1.66 \mathrm{Ma}$, and (4) 1.66 to $0.00 \mathrm{Ma}$. (Fig. 5). In interval 1, the sedimentation rates were moderate $(\sim 1.3 \mathrm{~cm} / \mathrm{k} . \mathrm{y}$.$) . Rates in-$ creased at the Chron 5/Chron 6 boundary which marks the transition from interval 1 to 2 . Rates remained high $(\sim 1.8 \mathrm{~cm} / \mathrm{k} . \mathrm{y}$.) during interval 2 until $3.4 \mathrm{Ma}$ when they returned to the moderate levels $(\sim 1.3 \mathrm{~cm} / \mathrm{k} . \mathrm{y}$.) observed during interval 3. Sedimentation rates during the interval 4 return to nearly the same level $(\sim 1.7$ $\mathrm{cm} / \mathrm{k} . \mathrm{y}$.) as in interval 2.

Exceptions to this general pattern are observed within the Olduvai (1.66 to $1.88 \mathrm{Ma}$ ) and Mammoth (3.08 to $3.18 \mathrm{Ma}$ ) Subchrons and between the subchron boundaries marking the lower Sidufjall (4.47 Ma) and the upper Thvera (4.57 Ma). Sedimentation rates during these intervals were significantly lower than during the immediately preceding or following intervals. Low sedimentation rates during the Mammoth Subchron are observed in both holes at Site 758, within Cores 121-758A-5H and 121-758B-5H. It is unlikely that missing sediment and/or a poor splice at the core break between Cores 121-758A-7H and 121$758 \mathrm{~A}-8 \mathrm{H}$, which separates the lower Sidufjall and the upper Thvera, can explain the low sedimentation rate of $0.76 \mathrm{~cm} / \mathrm{k} . \mathrm{y}$. between these reversals because the same low rate (of 0.75 $\mathrm{cm} / \mathrm{k} . \mathrm{y}$.) is observed in Core 121-758B-7H, which contains both reversals.

The dramatic drops in sedimentation rate at these reversal boundaries are curious. They most likely result from (1) a true decrease in sedimentation rate, (2) unrecognized hiatuses, (3) difficulties in reversal boundary identification, (4) unrecovered sediments, or (5) compression of the sedimentary section during the coring process. Although less likely, we cannot exclude the possibility that the age estimates for these magnetic reversal boundaries are in error. If the age estimates are erroneous, then so are the sedimentation rates. As an example, we consider different age estimates for the Olduvai Subchron and the resulting 

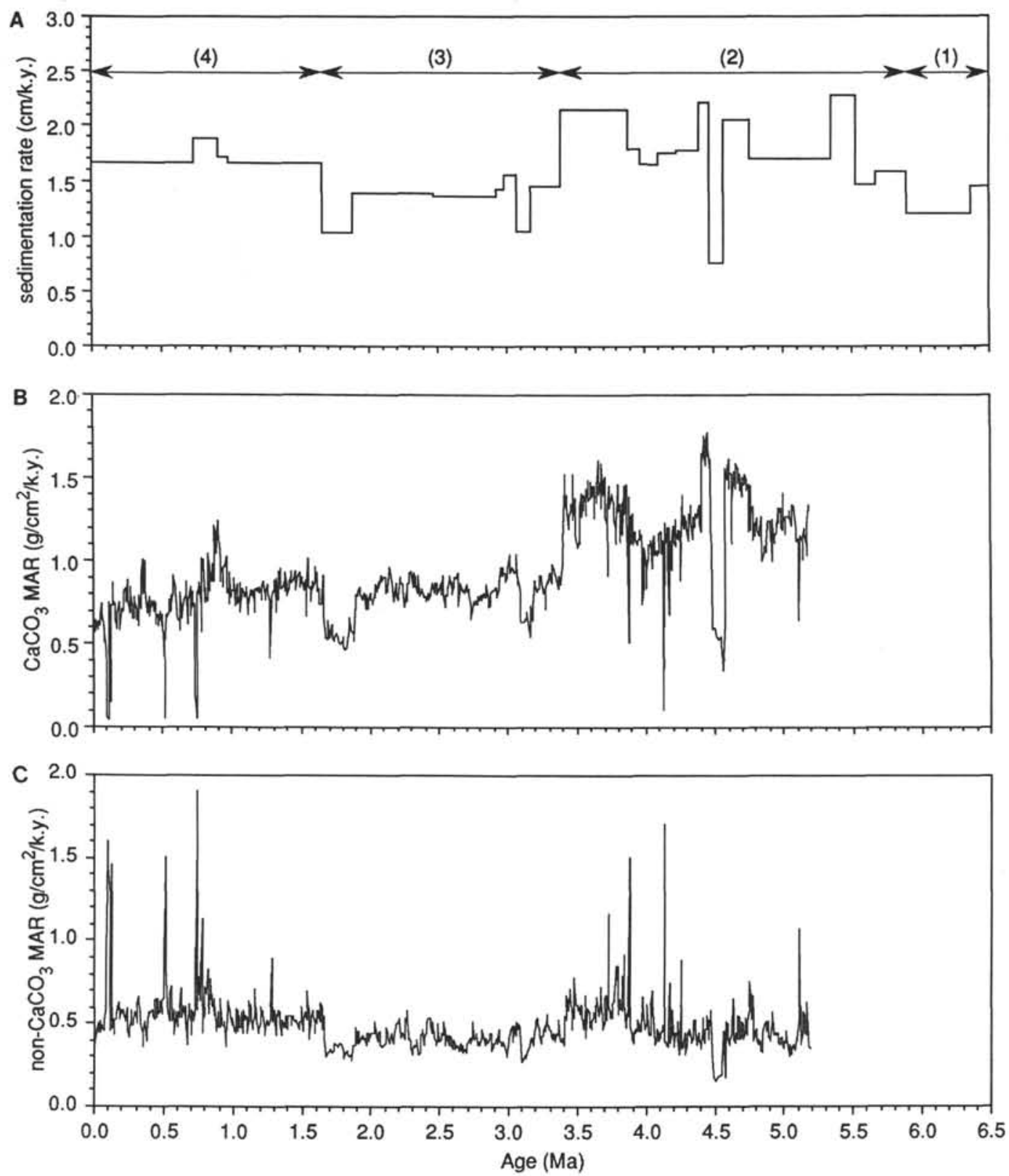

Figure 5. Comparison of Site 758 linear sedimentation rates (A) with mass accumulation rates of $\mathrm{CaCO}_{3}(\mathbf{B})$ and non- $\mathrm{CaCO}_{3}$ (C). Age is based on the geomagnetic reversal record (Table 2). Time intervals 1 through 4 in (A) are discussed in text. Spikes in (B) and (C) show intervals of high ash concentration.

sedimentation rates. The Berggren et al. (1985) ages for the top and bottom of the Olduvai are 1.66 and $1.88 \mathrm{Ma}$, respectively. These age estimates are slightly older than those recently proposed by Raymo et al. (1989) of 1.65 and $1.82 \mathrm{Ma}$ for the top and bottom of the Olduvai. In addition, the duration of the Olduvai Subchron based on the Raymo et al. (1989) ages is shorter than the duration based on the Berggren et al. (1985) ages. The Raymo et al. (1989) ages give an Olduvai sedimentation rate of 1.33 $\mathrm{cm} / \mathrm{k} . \mathrm{y}$., which is $22 \%$ higher than the $1.03 \mathrm{~cm} / \mathrm{k}$.y. rate based on the Berggren et al. (1985) ages. The higher sedimentation rates from the Raymo et al. (1989) ages results in a less dramatic decrease in sedimentation rates during the Olduvai compared to the time intervals preceding and following the Olduvai.

A preliminary time scale for the past $1 \mathrm{~m} . \mathrm{y}$. was constructed (Table 3; Fig. 6) by visual correlation of the Site 758 composite $\delta^{18} \mathrm{O}$ record to the SPECMAP stack global average oxygen isotope record (Imbrie et al., 1984; Prell et al., 1986), and to the Atlantic Site 607 benthic $\delta^{18} \mathrm{O}$ record (Ruddiman et al., 1989). The ages assigned to $\delta^{18} \mathrm{O}$ events 1 through 20 are from Imbrie et al. (1984) and the ages for events 21 through 35 are from Ruddiman et al. (1989). Linear sedimentation rates (Table 3) are calculated between each depth interval assigned an age. Tentative identification of $\delta^{18} \mathrm{O}$ events 23 to 105 in the Site 758 record (Fig. 7 ) is based on the correlation to the Site 607 record (Ruddiman et al., 1989; Raymo et al., 1989) and is supported by comparison with the planktonic and benthic $\delta^{18} \mathrm{O}$ stratigraphies from equatorial Pacific Site 677 (Shackleton and Hall, 1989; Shackleton et al., in press). The identification of $\delta^{18} \mathrm{O}$ events and the resulting age model for Site 758 (discussed below) is preliminary and will likely be adjusted in future work. The late Quaternary sedimenta- 
Table 3. $\delta^{18} \mathrm{O}$ chronostratigraphy and sedimentation rates for the Site $\mathbf{7 5 8}$ composite record.

\begin{tabular}{|c|c|c|c|}
\hline $\begin{array}{l}\text { Composite } \\
\text { depth } \\
\text { (m) }\end{array}$ & $\begin{array}{l}\text { Age } \\
(\mathrm{Ka})\end{array}$ & $\begin{array}{c}\text { Sedimentation } \\
\text { rate } \\
(\mathrm{cm} / \mathrm{k} . \mathrm{y} .)\end{array}$ & $\begin{array}{c}\delta^{18} \mathrm{O} \\
\text { stages }\end{array}$ \\
\hline 0.00 & 0 & & (core top) \\
\hline 0.11 & 6 & 1.8 & 1.1 \\
\hline 0.41 & 19 & 2.3 & 2.2 \\
\hline 1.11 & 53 & 2.1 & 3.3 \\
\hline 1.36 & 65 & 2.1 & 4.2 \\
\hline 1.51 & 71 & 2.5 & 5.0 \\
\hline 2.21 & 80 & 7.8 & .5 .1 \\
\hline 2.41 & 99 & 1.1 & 5.3 \\
\hline 2.71 & 122 & 1.3 & 5.5 \\
\hline 3.01 & 135 & 2.3 & 6.2 \\
\hline 3.51 & 171 & 1.6 & 6.5 \\
\hline 3.71 & 183 & 1.7 & 6.6 \\
\hline 3.91 & 194 & 1.8 & 7.1 \\
\hline 4.01 & 205 & 0.9 & 7.2 \\
\hline 4.18 & 216 & 1.5 & 7.3 \\
\hline 4.41 & 228 & 1.9 & 7.4 \\
\hline 4.64 & 238 & 2.3 & 7.5 \\
\hline 4.96 & 249 & 2.9 & 8.2 \\
\hline 5.11 & 257 & 1.9 & 8.3 \\
\hline 5.32 & 269 & 1.8 & 8.4 \\
\hline 5.52 & 287 & 1.1 & 8.5 \\
\hline 5.67 & 299 & 1.3 & 8.6 \\
\hline 6.32 & 331 & 2.0 & 9.3 \\
\hline 6.62 & 341 & 3.0 & 10.2 \\
\hline 7.43 & 405 & 1.3 & 11.3 \\
\hline 7.63 & 434 & 0.7 & 12.2 \\
\hline 8.13 & 478 & 1.1 & 13.0 \\
\hline 8.23 & 491 & 0.8 & 13.12 \\
\hline 8.33 & 513 & 0.5 & 13.2 \\
\hline 8.43 & 525 & 0.8 & 13.3 \\
\hline 8.63 & 538 & 1.5 & 14.2 \\
\hline 8.73 & 552 & 0.7 & 14.3 \\
\hline 9.03 & 563 & 2.7 & 14.4 \\
\hline 9.38 & 574 & 3.2 & 15.1 \\
\hline 9.63 & 585 & 2.3 & 15.2 \\
\hline 9.83 & 596 & 1.8 & 15.3 \\
\hline 9.93 & 607 & 0.9 & 15.4 \\
\hline 10.03 & 617 & 1.0 & 15.5 \\
\hline 10.28 & 631 & 1.8 & 16.23 \\
\hline 10.98 & 679 & 1.5 & 17.2 \\
\hline 11.38 & 700 & 1.9 & 18.23 \\
\hline 11.58 & 711 & 1.8 & 18.3 \\
\hline 11.78 & 721 & 2.0 & 18.4 \\
\hline 12.03 & 731 & 2.5 & 19.1 \\
\hline 12.58 & 750 & 2.9 & 20.23 \\
\hline 13.18 & 775 & 2.4 & 21 \\
\hline 13.73 & 799 & 2.3 & 22 \\
\hline 14.03 & 819 & 1.5 & 23 \\
\hline 14.28 & 838 & 1.3 & 24 \\
\hline 14.58 & 859 & 1.4 & 25 \\
\hline 15.18 & 881 & 2.7 & 26 \\
\hline 15.53 & 906 & 1.4 & 27 \\
\hline 15.73 & 922 & 1.3 & 28 \\
\hline 15.93 & 946 & 0.8 & 29 \\
\hline 16.33 & 965 & 2.1 & 30 \\
\hline 16.83 & 985 & 2.5 & 31 \\
\hline 17.92 & 1068 & 1.3 & 35 \\
\hline
\end{tabular}

Note: $\delta^{18} \mathrm{O}$ stages 1 through 20 are from Imbrie et al. (1984) and stages 21 through 35 are from Ruddiman et al. (1989).

tion rates based on $\delta^{18} \mathrm{O}$ show much greater variations in amplitude and timing than the rates based on magnetic reversals (Fig. 6 ). This difference demonstrates that variations in sedimentation rate and thus ocean and climate change is inadequately captured by the geomagnetic reversal record which gives a constant sedimentation rate for the Brunhes Chron (Figs. 5 and 6). High-resolution age models are required for high-resolution paleoenvironmental analysis.

\section{RESULTS}

\section{Isotope Stratigraphy}

The $\delta^{13} \mathrm{C}$ and $\delta^{18} \mathrm{O}$ data are plotted vs. depth in Figure 8 , plotted vs. age in Figures 9 and 10, and are listed in Appendixes $\mathrm{D}, \mathrm{E}$, and $\mathrm{F}$. The d180 record can be divided into two distinct intervals at approximately $14 \mathrm{~m}\left(\delta^{18} \mathrm{O}\right.$ stage 23 ; Fig. 7$)$. The Holocene and the upper Pleistocene ( 0 to $14 \mathrm{~m})$ contains $\delta^{18} \mathrm{O}$ stages 1 to 22 and is characterized by high-amplitude (1\%o$2 \%$ ), 100-k.y. $(100-150 \mathrm{~cm})$ cycles. The most depleted (interglacial) $\delta^{18} \mathrm{O}$ value is $-2.26 \%$ and the most enriched (glacial) value is $-0.33 \%$. This interval has more enriched $\delta^{18} \mathrm{O}$ values $(\overline{\mathrm{x}}$ $=-1.21 \% o$ ) and higher variability $(\sigma=0.43)$ than the interval below $14 \mathrm{~m}$. The $\delta^{18} \mathrm{O}$ record in the upper $14 \mathrm{~m}$ from Site 758 is quite similar to the SPECMAP-stacked $\delta^{18} \mathrm{O}$ record (Imbrie et al., 1984; Prell et al., 1986) (Fig. 6). Compared to the SPECMAP $\delta^{18} \mathrm{O}$ record, the record from Site 758 shows relatively enriched substages 5.5 and 18.4, and depleted substages 15.1 and 13.2.

The lower interval ( 14 to $39 \mathrm{~m}$ ) lies within the upper Pliocene and lower Pleistocene, and contains $\delta^{18} \mathrm{O}$ stages 23 to 105 . Compared to the overlying interval, the $\delta^{18} \mathrm{O}$ record in the lower interval is characterized by higher frequency ( $40 \mathrm{k} . \mathrm{y}$.$) and lower$ amplitude $(<1 \%$ ) fluctuations. The values are also more depleted $(\overline{\mathrm{x}}=-1.50 \%)$ and have a lower variability $(\sigma=0.24)$. While $\delta^{18} \mathrm{O}$ events with depleted values reach $-2.21 \%$, similar to those in the overlying interval, events with enriched values reach only $-0.73 \%$ much less than in the overlying interval. In other words, the interglacial stages of the upper and lower intervals were similar while the glacial stages of the late Pleistocene were more severe, indicating some combination of greater ice volume, colder sea surface temperatures, or higher salinity during the late Pleistocene. The periodicities of $\sim 40 \mathrm{k} . \mathrm{y}$. in the late Pleistocene and $\sim 100$ k.y. in the late Pliocene and early Pleistocene are clearly evident, even without spectral analysis. These periodicities can be estimated by simply dividing time intervals, determined by magnetic reversal ages, by the number of $\delta^{18} \mathrm{O}$ cycles. The $\delta^{13} \mathrm{C}$ record also shows long- and short-term variability but the change at $14 \mathrm{~m}$ is not as distinct as in $\delta^{18} \mathrm{O}$. The mean $\delta^{13} \mathrm{C}$ value increases from $1.13 \%$ in the overlying interval, to $1.34 \%$ o below, but the standard deviation is nearly the same, increasing from 0.18 to only 0.21 .

Using the nomenclature of Ruddiman et al. (1989) and Raymo et al. (1989), isotope stages 23 through 105 have been identified in the Site 758 record (Fig. 7). Support for stage identification is based on the comparison to the Site 677 record (Shackleton and Hall, 1989; Shackleton et al., in press). Although we are confident in the completeness of our composite depth section and in the magnetic age control, correlation of the Site 758 record to that in Site 607 (Ruddiman et al., 1989; Raymo et al., 1989) is difficult and perhaps tenuous for several reasons. First, we are comparing significantly different $\delta^{18} \mathrm{O}$ records. The Site 758 record is from the equatorial Indian Ocean and is based on planktonic foraminifers. The Site 607 record is from the North Atlantic and is based on benthic foraminifers. Fluctuations in global ice volume will have an identical impact on the $\delta^{18} \mathrm{O}$ from both records. Nevertheless, water temperature and salinity also effect $\delta^{18} \mathrm{O}$. The history of temperature and salinity fluctuations in the abyssal waters of the North Atlantic is undoubtedly different than the history in the surface waters of the equatorial Indian Ocean. Since ice volume fluctuations are the primary control of $\delta^{18} \mathrm{O}$ in these records, the timing of the $\delta^{18} \mathrm{O}$ fluctuations is generally similar at Sites 758 and 607 . The major difference between the records is in the amplitude of the $\delta^{18} \mathrm{O}$ variations due to differences in temperature and salinity. The second is the difference in temporal resolution of the records from Sites 758 and 607 . Site 758 was 


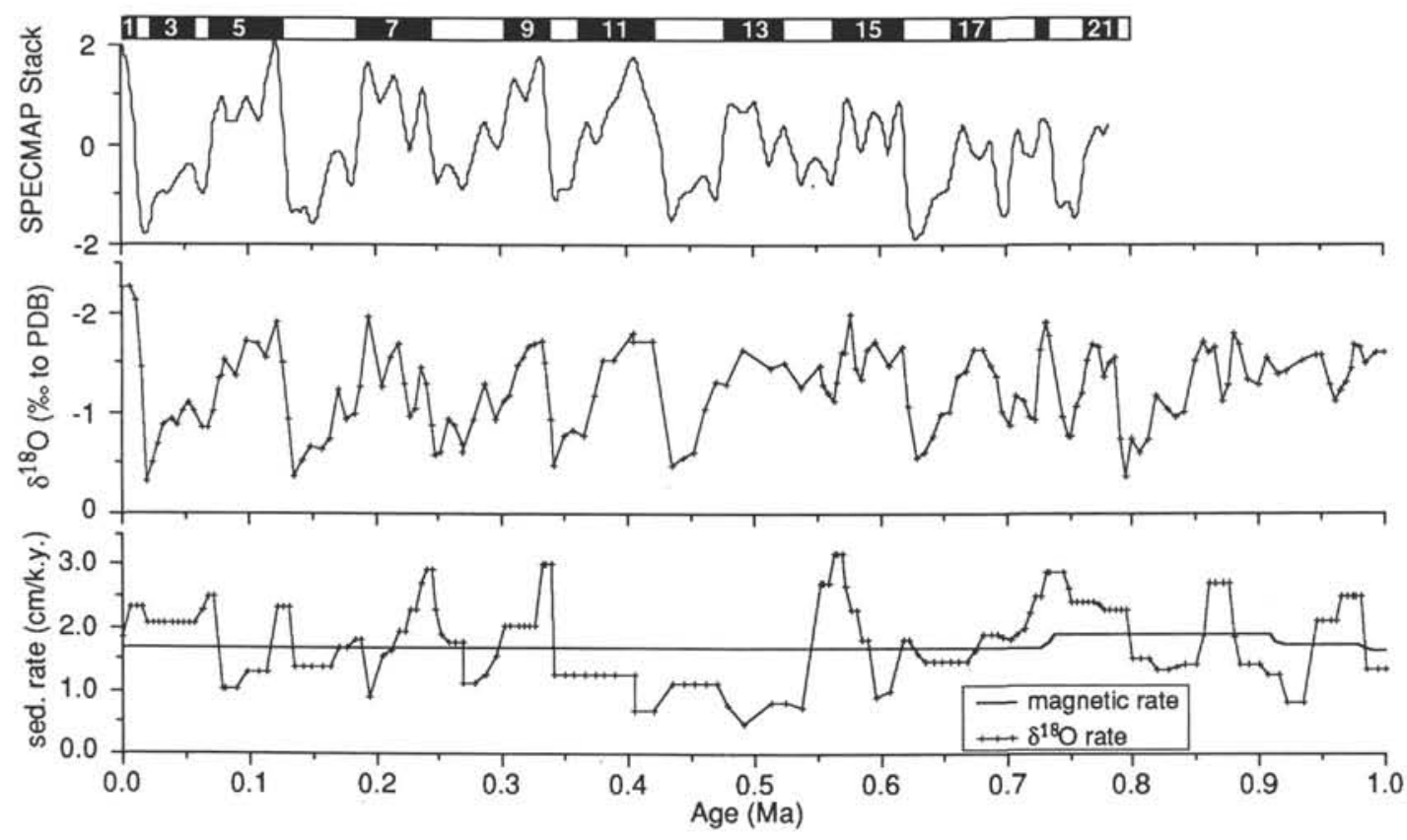

Figure 6. Oxygen isotope records from the SPECMAP stack (Imbrie et al., 1984) and from Site 758 plotted vs. age. The SPECMAP stack is plotted in standard deviation units. Odd-numbered intervals in legend refer to interglacial stages. Estimates of sedimentation rate are plotted vs. age and are based on the geomagnetic reversal record (Table 2) and on the $\delta^{18} \mathrm{O}$ age model (Table 3 ).
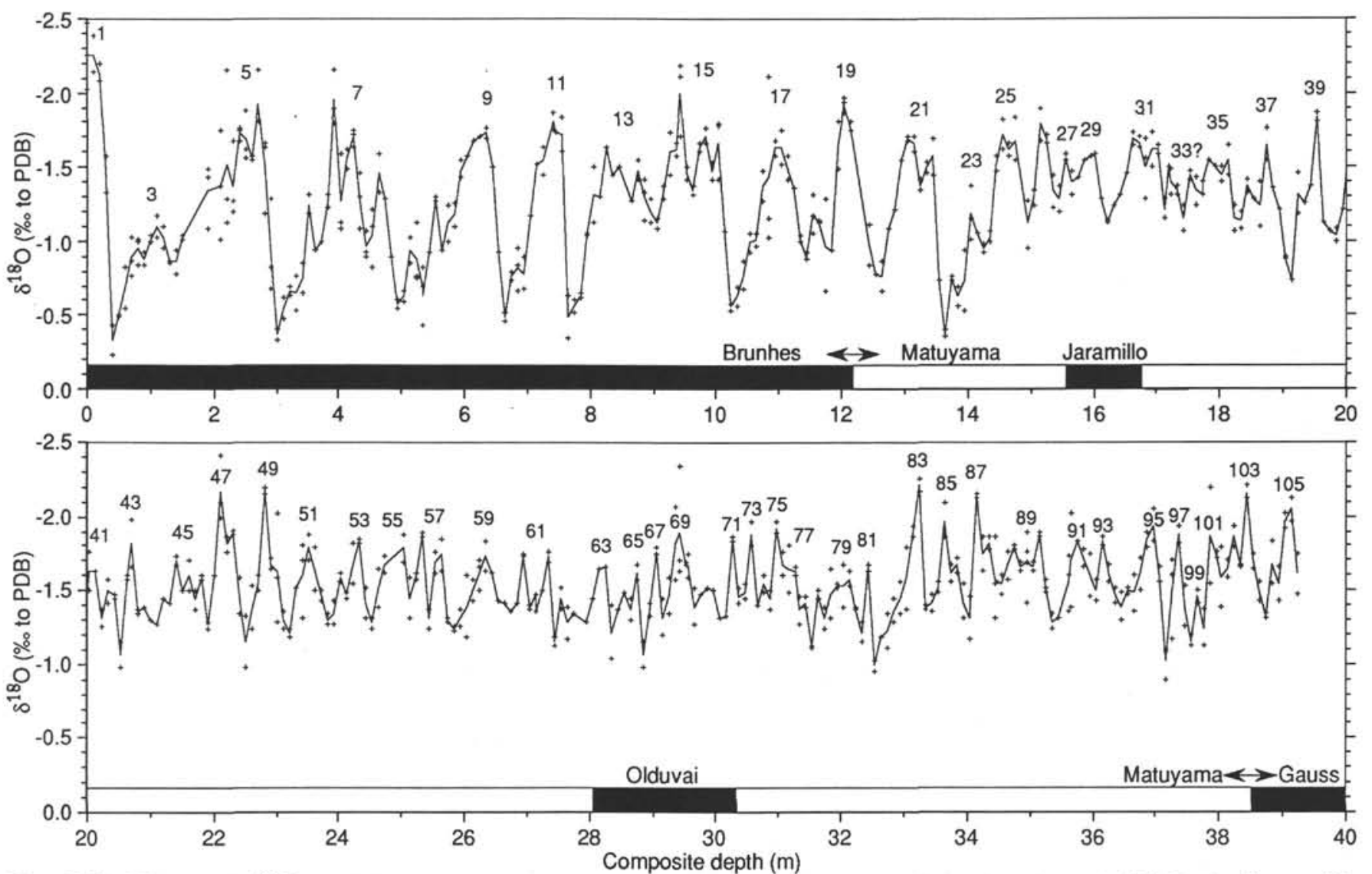

Figure 7. Site 758 composite $\delta^{18} \mathrm{O}$ record plotted to composite depth. Solid line connects the mean of individual analyses (crosses) of Globigerinoides sacculifera at each depth. Odd numbers refer to interglacial stages. Stages 1 to 20 are correlated to the SPECMAP stack (Imbrie et al., 1984). Preliminary identification of stages 21 to 105 is based on correlation to the Site 607 record (Ruddiman et al., 1989; Raymo et al., 1989). 


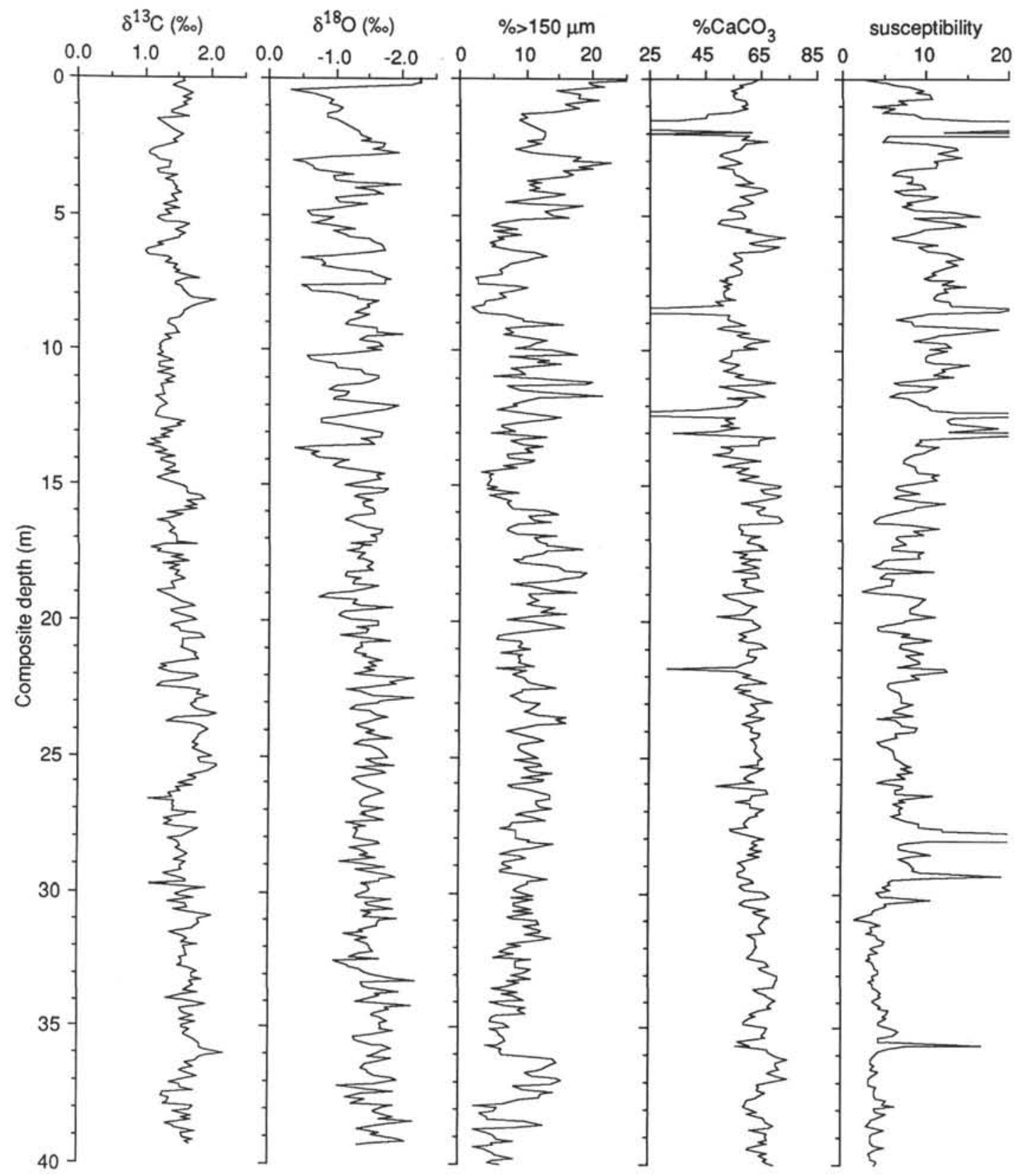

Figure 8. Site 758 composite $\delta^{13} \mathrm{C}$ and $\delta^{18} \mathrm{O}$ (G. sacculifera), wt $\% \mathrm{CaCO}_{3}$, wt $\%$ coarse fraction $(>150 \mu \mathrm{m})$, and magnetic susceptibility $\left(10^{-6} \mathrm{cgs}\right)$ records vs. composite depth.

sampled at $10 \mathrm{~cm}$ vs. $16 \mathrm{~cm}$ for Site 607 (Ruddiman et al., 1989; Raymo et al, 1989). However, during the past 2.7 m.y., the average sedimentation rate at Site 607 is $\sim 4.4 \mathrm{~cm} / \mathrm{k} . \mathrm{y}$., which is three times greater than the average rate of $1.5 \mathrm{~cm} / \mathrm{k} . \mathrm{y}$. at Site 758 . Because the differences in sedimentation rate are much greater than the differences in sample spacing, the average sample resolution of the Site 607 record is $3.6 \mathrm{k} . \mathrm{y}$., which is nearly twice the resolution of the 6.4-k.y. spacing in the Site 758 record. Due to the lower sedimentation rate at Site 758 , the isotopic variations are more likely to be blurred compared to those in the Site 607 record. Finally, detailed biostratigraphic information that would provide additional points of correlation is not yet available.

Despite the difficulties in correlation, the general agreement between the structure and timing of the two isotope records suggests that isotope stages 21 through 105 can be correlated from
Site 607 to Site 758. Particularly favorable comparisons between the two records are as follows: (1) the Brunhes/Matuyama boundary is found in stage $19 ;(2)$ the Jaramillo top occurs in stage 27 and the bottom in stage 31 ; (3) stages 57 and 61 are split peaks; (4) stages 78 and 82 are relatively enriched in ${ }^{18} \mathrm{O}$ compared to other glacial stages; (5) stages 96,98 , and 100 are moderately strong glacials associated with the initiation of significant Northern Hemisphere glaciation (Raymo et al., 1989); and (6) the Matuyama/Gauss boundary occurs in stage 104. Minor differences between the isotope records occur near the Olduvai Subchron. The top of the Olduvai falls within stage 63 at Site 758 but in stage 64 at Site 607. If the deepest end of the uncertainty range in Site 758 is used, the reversal occurs near the transition from stage 63 to 64 . The bottom of the Olduvai falls within stage 74 at Site 758 but is found in stage 72 at Site 607 . Because stage 73 is 


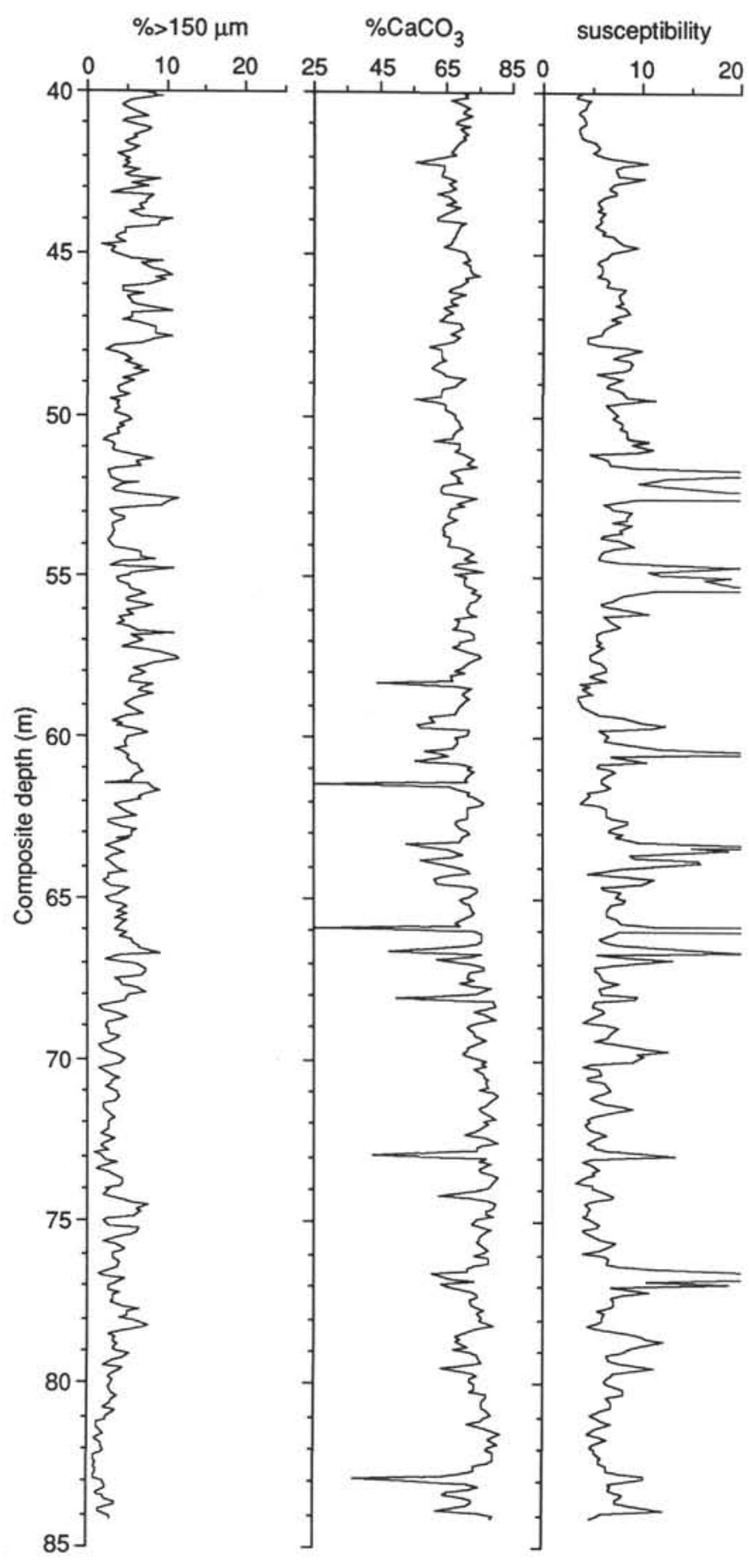

Figure 8 (continued).

poorly defined by only one point (although duplicated) in the Site 758 record, we have less confidence in our correlation to Site 607 at this interval.

\section{$\mathrm{Wt} \% \mathrm{CaCO}_{3}$ Stratigraphy}

The wt $\% \mathrm{CaCO}_{3}$ data are plotted vs. depth in Figure 8, plotted vs. age in Figures 9, 10, and 11, and are listed in Appendixes B, $\mathrm{C}$, and $\mathrm{F}$. $\mathrm{CaCO}_{3}$ is the dominant sedimentary component and accounts for an average of $66.3 \%$ of the bulk sediment over the past $5.2 \mathrm{~m} . \mathrm{y}$. The $\mathrm{CaCO}_{3}$ content ranges from $2.7 \%$ (in volcanic ash horizons) to $81.1 \%$ and generally increases downhole (Fig.
11). This long-term downhole trend is punctuated by low wt $\%$ $\mathrm{CaCO}_{3}$ intervals which mark the locations of ash layers. Excluding these layers, the mean $\mathrm{wt} \% \mathrm{CaCO}_{3}$ value increases gradually from $58.3 \%$ during the interval $0-1 \mathrm{Ma}$ to $73.7 \%$ during 4-5 Ma. This downhole increase is accompanied by a progressive lightening of sediment color (Shipboard Scientific Party, 1989), generally lower MS values, and lower wt $\%$ coarse fraction (Fig. 11). Higher frequency $\mathrm{CaCO}_{3}$ variations, on the order of $10 \%$ to $15 \%$, are superimposed on the long-term trend.

The late Pleistocene wt $\% \mathrm{CaCO}_{3}$ record is characterized by generally higher values during interglacial intervals than during glacials (Fig. 9). The $\mathrm{CaCO}_{3} \mathrm{MAR}$, however, occasionally moves the peak $\mathrm{CaCO}_{3}$ events from the middle of interglacial intervals toward the glacial to interglacial transition, a result of increased sedimentation rates at transitions between $\delta^{18} \mathrm{O}$ stages (Fig. 6 and 9).

A shift toward higher wt $\% \mathrm{CaCO}_{3}$ occurs near $0.8 \mathrm{Ma}$, at about $14 \mathrm{~m}$ in the composite depth record (Fig. 8). Excluding obvious ash horizons, the wt $\% \mathrm{CaCO}_{3}$ values of the top $14 \mathrm{~m}(\overline{\mathrm{x}}=57 \%)$ are lower than those in the next $14 \mathrm{~m}(\overline{\mathrm{x}}=62 \%)$. The wt $\% \mathrm{CaCO}_{3}$ shift coincides with the $\delta^{18} \mathrm{O}$ shift described above, a lightening of sediment color, a decrease in MS, and the distinct change in the mode of variability in the $\delta^{18} \mathrm{O}$ record

\section{Coarse Fraction Stratigraphy}

The wt $\%$ coarse fraction $(>150 \mu \mathrm{m})$ data, which range from $0.79 \%$ to $28.49 \%$ and average $7.22 \%$, are plotted vs. depth in Figure 8, plotted vs. age in Figures 9, 10, and 11, and are listed in Appendixes B, C, and F. The sediment in this fraction is almost exclusively biogenic $\mathrm{CaCO}_{3}$, primarily consisting of whole and fragmented foraminifers. Volcanic ash is rarely a component. No portion of the coarse fraction is composed of nonvolcanic terrigenous sediment. The most apparent trend to the data is the longterm, downhole decrease. Superimposed on this trend are fluctuations at both high and low frequencies.

Coarse fraction percent is generally considered a reliable index of $\mathrm{CaCO}_{3}$ dissolution (Berger, 1970; Berger et al., 1982). If winnowing and bottom-water turbulence are minimal, the systematic decrease in wt\% coarse fraction with increasing water depth can be attributed to dissolution-induced fragmentation of foraminifer tests. Increased fragmentation of fossil assemblages and decreased wt $\%$ coarse fraction from core top and downhole samples from the Ninetyeast Ridge (near $6^{\circ} \mathrm{S}$ ) have been directly related to dissolution (Peterson and Prell, 1985a, 1985b). The increase in dissolution with depth is attributed to a progressive increase in the corrosiveness (lower carbonate ion concentration) of the Indian Deep and Bottom Waters. Preliminary analysis of the preservation state of the foraminifer faunal assemblages at Site 758 (Chen and Farrell, this volume) shows a generally good agreement between the wt $\%$ coarse fraction and foraminifer preservation over the interval from 0 to $800 \mathrm{Ka}$. Until quantitative analysis of the assemblages is completed for the entire late Neogene interval, the wt $\%$ coarse fraction serves as the best estimate of relative dissolution at Site 758 .

\section{Magnetic Susceptibility Stratigraphy and Volcanic Ash}

The MS data are plotted vs. ODP depth in Figure 3 (back pocket), plotted vs. composite depth in Figure 8, and plotted vs. age in Figures 9, 10, and 11. MS values interpolated at the depth of the samples in our wt $\% \mathrm{CaCO}_{3}$ and isotope database are listed in Appendix F. MS values in Site 758 sediments have increased since $7.3 \mathrm{Ma}$, but not monotonically. The low MS values in the uppermost Miocene suggest only minor input of terrigenous sediment and little to no volcanic ash; no discrete ash layers are found in the Miocene. High wt $\% \mathrm{CaCO}_{3}$ values in this same section support this contention. Spikes in the MS stratigraphy denote ash 


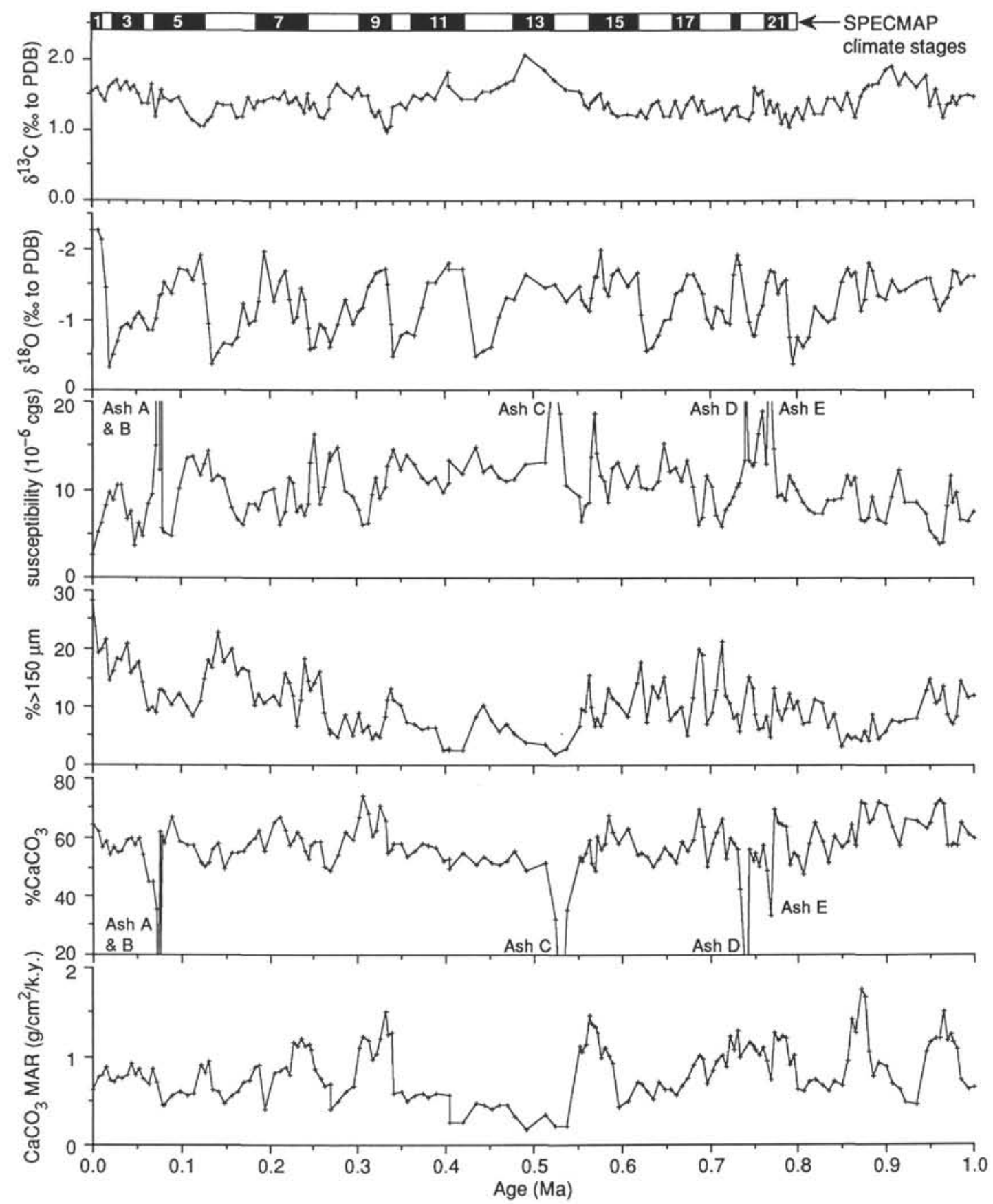

Figure 9. Site 758 composite records of $\delta^{13} \mathrm{C}, \delta^{18} \mathrm{O}$, magnetic susceptibility $(10-6 \mathrm{cgs})$, wt $\%$ coarse fraction ( $>150 \mathrm{~mm}$ ), wt $\%$ $\mathrm{CaCO}_{3}$, and $\mathrm{CaCO}_{3} \mathrm{MAR}$ vs. age based on the $\delta^{18} \mathrm{O}$ age model (Table 3). Depths of major ash layers are labeled. Odd-numbered intervals in the legend refer to interglacial stages.

blebs and layers which begin to appear in the early Pliocene. The increase in average MS values within the lower Pliocene (Fig. 3, back pocket) indicates the presence of disseminated ash and/or an increase in nonvolcanic terrigenous sediment (clay) input. A sharp reduction in average MS values occurs within the section between 2.7 and $1.9 \mathrm{Ma}$ (Fig. 11). Since sedimentation rates are also reduced in this interval, part of the reduction in average MS values may be due to a decrease in the accumulation rate of magnetizable material. Following $1.9 \mathrm{Ma}$, the MS values increase as terrigenous sedimentation and the input of volcanic ash increased. The highest average MS values occurs within the upper
Pleistocene where wt $\% \mathrm{CaCO}_{3}$ is lowest, the sediment color is darkest, and terrigenous sedimentation is relatively high.

Thirteen major volcanic ash layers are observed in the uppermost $116 \mathrm{~m}$ from Site 758 . These layers appear as low wt $\% \mathrm{CaCO}_{3}$ spikes in Figures 5, 8, 9, 10, and 11 and as high MS spikes in Figures $3,4,8,9,10$, and 11 . The magnetic material in the ash is largely responsible for the high quality of the MS and magnetic declination signals. The concentration of ash in the sediments ranges from minor amounts disseminated through much of the section, to major ash layers such as the youngest Toba ash $(\sim 75$ $\mathrm{Ka}$ ), which is $34 \mathrm{~cm}$ thick in Hole $758 \mathrm{~A}$. If ages are determined 
for these ash layers by independent means, such as the ${ }^{40} \mathrm{Ar} /{ }^{39} \mathrm{Ar}$ method (McDougall and Harrison, 1988), these layers will become chronostratigraphic markers with the potential to test the veracity of the geomagnetic reversal and $\delta^{18} \mathrm{O}$ chronostratigraphies.

\section{DISCUSSION}

We focus this discussion on two time scales and two time slices during which important changes are observed in one or more of the oceanic and climatic indices. We consider long-term change on the time scale from 0 to $5 \mathrm{Ma}$, and short-term change from 0 to $1 \mathrm{Ma}$. The two time slices examined are the $2.4 \mathrm{Ma}$ initiation of significant Northern Hemisphere glaciation, and the mid-Pleistocene climate shift near $0.85 \mathrm{Ma}$.

\section{Long-Term Change in the Northeastern Indian Ocean}

$\mathrm{CaCO}_{3}$ preservation appears to have increased since at least 5 $\mathrm{Ma}$. This is based on the long-term and rather monotonic increase in wt\% coarse fraction (Fig. 11). Clearly superimposed on this trend are higher frequency fluctuations at a variety of periodicities. The interpretation of enhanced preservation is based on the assumption that wt $\%$ coarse fraction measures dissolution intensity. Alternatively, the increase in wt $\%$ coarse fraction over time may reflect an increase in winnowing intensity due to faster flow of deep water. Evidence of winnowing was found at Site 707, located in intermediate-depth waters $(1500 \mathrm{~m})$ in the western equatorial Indian Ocean (Peterson and Backman, 1990). Beginning at $3.5 \mathrm{Ma}$, the sediments at this site show an a dramatic increase in foraminifer sand content. Most of the fine fraction, which is typical in deep-sea ooze, is not present. An abrupt increase in wt\% coarse fraction did not occur at 3.5 Ma nor at any other time in the Site 758 record. Although we cannot completely discount the possibility of enhanced winnowing at Site 758 , we present the following evidence to support our contention that the wt\% coarse fraction record from the Ninetyeast Ridge reflects $\mathrm{CaCO}_{3}$ preservation. In the late Pleistocene, $\mathrm{CaCO}_{3}$ preservation is clearly correlated to wt $\%$ coarse fraction since it covaries with dissolution indices that are based on planktonic foraminifers (Chen and Farrell, this volume). Detailed analysis of the preservation state of the planktonic foraminifers in the Pliocene interval has not yet been done. However, while picking G. sacculifera for isotope analysis, we observed a downhole decrease in the abundance of dissolution-susceptible species and an increase in the abundance of dissolution-resistant species. Furthermore, the foraminifers in lower Pliocene and upper Miocene samples from Cores 121-758A-7H and 121-758A-8H also appear to have been greatly altered by dissolution (W. Berggren, pers. comm., 1990). In several of these samples, the abundance of $G$. sacculifera, which is moderately susceptible to dissolution, was rare to absent. One explanation of the long-term increase in wt\% coarse fraction is a gradual decline in the corrosiveness of the water that bathes Site 758. Support for this contention comes from the long-term deepening of the Indian Ocean carbonate compensation depth (CCD) since -5 Ma observed in sedimentary records from the western equatorial Indian Ocean (Peterson and Backman, 1990) and the Bengal Fan (Stow et al. (1990).

Since $5 \mathrm{Ma}$, the long-term increase in wt\% coarse fraction was accompanied by a long-term decrease in wt $\mathrm{CaCO}_{3}$ (Fig. 11) and $\mathrm{CaCO}_{3}$ MAR (Fig. 5). Because the increase in wt\% coarse fraction apparently reflects an increase in preservation, the decline in wt\% $\mathrm{CaCO}_{3}$ and $\mathrm{CaCO}_{3}$ MAR is considered to represent a long-term increase in dilution by non- $\mathrm{CaCO}_{3}$ sediment and/or a decrease in $\mathrm{CaCO}_{3}$ productivity. However, the short-term fluctuations superimposed on these long-term $\mathrm{CaCO}_{3}$ trends could be controlled by dissolution. The decline in $\mathrm{CaCO}_{3} \mathrm{MAR}$ was not as monotonic as the decline in $\mathrm{wt} \% \mathrm{CaCO}_{3}$. Abrupt changes in $\mathrm{CaCO}_{3} \mathrm{MAR}$ reflect fluctuations in sedimentation rate derived from the paleomagnetic reversal record. These sedimentation rate changes do not effect the wt $\% \mathrm{CaCO}_{3}$ record. The variations in $\mathrm{CaCO}_{3} \mathrm{MAR}$ are not affected by terrigenous dilution and are not always in phase with changes in the wt $\% \mathrm{CaCO}_{3}$ record. If dissolution controlled the long-term patterns observed in the $\mathrm{CaCO}_{3}$ sediments, then the decrease in wt $\% \mathrm{CaCO}_{3}$ should be in phase with the decrease in $\mathrm{CaCO}_{3} \mathrm{MAR}$.

The most dramatic change in the $\mathrm{CaCO}_{3}$ MAR record is the $50 \%$ decrease at $3.4 \mathrm{Ma}$ (Fig. 5) from a mean value of approximately $1.35 \mathrm{~g} / \mathrm{cm}^{2} / \mathrm{k}$.y. to $0.7 \mathrm{~g} / \mathrm{cm}^{2} / \mathrm{k}$.y. The timing and relative size $(50 \%)$ of this $\mathrm{CaCO}_{3}$ MAR decrease has also been observed in records from Legs 115 (Peterson and Backman, 1990) and 117 (Prell, Niitsuma, et al., 1989) suggesting that the decrease occurred over much of the Indian Ocean. This $\mathrm{CaCO}_{3} \mathrm{MAR}$ decrease in sites from Legs 115 and 117 was interpreted as a drop in productivity (Peterson and Backman, 1990; Prell, Niitsuma, et al., 1989). This interpretation is consistent with the records from Site 758. The drop in $\mathrm{CaCO}_{3} \mathrm{MAR}$ at Site 758 is interpreted as a decline in productivity because wt $\%$ coarse fraction increases across this interval, indicating enhanced preservation, and because dilution (an increase in non- $\mathrm{CaCO}_{3} \mathrm{MAR}$ ) did not increase at 3.4 Ma. The widespread occurrence of this drop in $\mathrm{CaCO}_{3} \mathrm{MAR}$ near 3.4 Ma suggests a major reorganization of surface-water productivity over much of the Indian Ocean. If productivity has decreased since $5 \mathrm{Ma}$, then the long-term increase in $\mathrm{CaCO}_{3}$ preservation indicated by the wt $\%$ coarse fraction record may be partly related to a decrease in the flux ratio of organic carbon $\left(\mathrm{C}_{\text {org }}\right)$ to $\mathrm{CaCO}_{3}$ carbon $\left(\mathrm{C}_{\mathrm{CaCO}_{3}}\right)$. If the high rates of $\mathrm{CaCO}_{3}$ MAR during the latest Miocene and early Pliocene were produced by elevated productivity levels, then it is likely that the flux ratio of organic carbon to $\mathrm{CaCO}_{3}$ to the seafloor was higher. Degradation of the organic carbon in the surface sediments could lead to significant dissolution and thus low wt $\%$ coarse fraction even if the hydrographic lysocline at that time was situated far below the depth of the site (Emerson and Bender, 1981; Peterson and Prell, 1985a). Secession of high productivity near 3.4 Ma may have led to a decrease in the flux ratio of $\mathrm{C}_{\text {org }}: \mathrm{C}_{\mathrm{CaCO}_{3}}$ and thus an increase in preservation. Elevated levels of $\mathrm{C}_{\text {org }}$ and $\mathrm{CaCO}_{3}$ MAR during the early Pliocene at Arabian Sea Site 722 (Murray and Prell, 1991) support the link between $\mathrm{C}_{\text {org }}$ and $\mathrm{CaCO}_{3}$ preservation.

Variations in the MS record are difficult to interpret without a greater understanding of the sedimentary components and the magnetic parameters of the record. For example, grain size as well as concentration of the magnetic minerals can determine the amplitude of the susceptibility measurements (Thompson and Oldfield, 1986). Furthermore, deconvolution of the MS record into paleoenvironmental parameters is more difficult at Site 758 than at other sites, such as those on Leg 117 (deMenocal and Bloemendal, 1991), because the signal at Site 758 contains not only silt and clay but ash as well. If we assume, however, that the average MS values at Site 758 record some measure of the longterm change in the ratio of $\mathrm{CaCO}_{3}$ to clay sedimentation, then the trend of increasing MS since 7.3 Ma (Fig. 11) shows a decrease in $\mathrm{CaCO}_{3}$ sedimentation and/or an increase in non- $\mathrm{CaCO}_{3}$ sedimentation. This interpretation is supported by the uphole decrease in $\mathrm{CaCO}_{3} \mathrm{MAR}$ and increase in non- $\mathrm{CaCO}_{3} \mathrm{MAR}$ (Fig. 5), as well as the uphole trend of decreasing $\mathrm{wt} \% \mathrm{CaCO}_{3}$ (Fig. 11).

The increase in terrigenous input from at least 7.3 to 0 Ma may be partly related to subsidence and northward movement of Site 758 closer to the source of riverine sediments. This contribution is probably minimal, however, since paleobathymetric and back- 


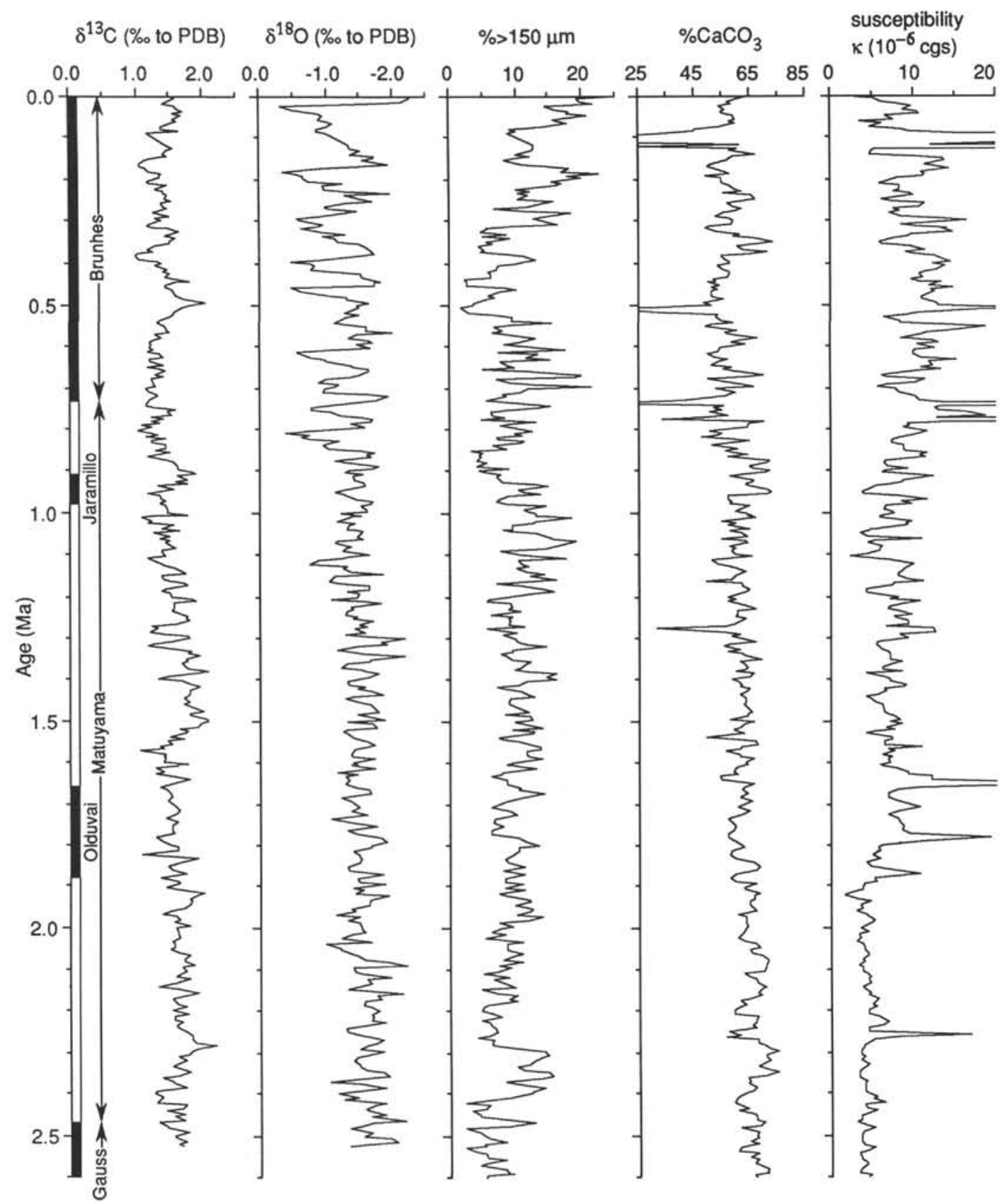

Figure 10. Site 758 composite $\delta^{13} \mathrm{C}$ and $\delta^{18} \mathrm{O}\left(\mathrm{G}\right.$. sacculifera), wt $\% \mathrm{CaCO}_{3}$, wt $\%$ coarse fraction $(>150 \mu \mathrm{m})$, and magnetic susceptibility records vs. age based on the geomagnetic reversal age model (Table 2).

track estimates suggest a deepening of no more than $200 \mathrm{~m}$ and northward movement of only $\sim 2.5^{\circ}$ since $5 \mathrm{Ma}$ (Peirce, Weissel et al., 1989). Alternatively, the increase in terrigenous sedimentation could be linked to an increase in sediment discharge into the Bengal Bay. Most of the riverine sediment transported to the Ganges delta and shelf region would ultimately be deposited in the deep sea by turbidity currents. These sediments formed the Bengal Fan. Powerful turbidity currents carried sediments more than $2500 \mathrm{~km}$ from the Ganges delta and deposited beds up to 2.5 $\mathrm{m}$ thick (Stow et al., 1990). The coarser-grained sands and muds were deposited on the Bengal Fan closer to the delta. During turbidity flows, the finer sediments, predominantly silts and clays, were most likely entrained into nepheloid layers or mixed up- wards into shallower waters. Some silts and clay were deposited at Site 758 , atop the Ninetyeast Ridge, which lies $\sim 1000 \mathrm{~m}$ above the Bengal Fan.

Greater sediment discharge by the Ganges-Brahmaputra river system over this time interval is ultimately related to increased rates of Himalayan uplift and denudation during the latest Miocene and Pliocene (Raymo et al., 1988, and references therein). Intensification of monsoonal rains resulting from an elevated Himalayan front and greater land/sea contrast due to a higher Tibetan Plateau would contribute a positive feedback by supplying greater river flow and erosional force (Raymo et al., 1988). The many causative links between uplift and terrigenous sedimentation at the Ninetyeast Ridge are complex and quite speculative 


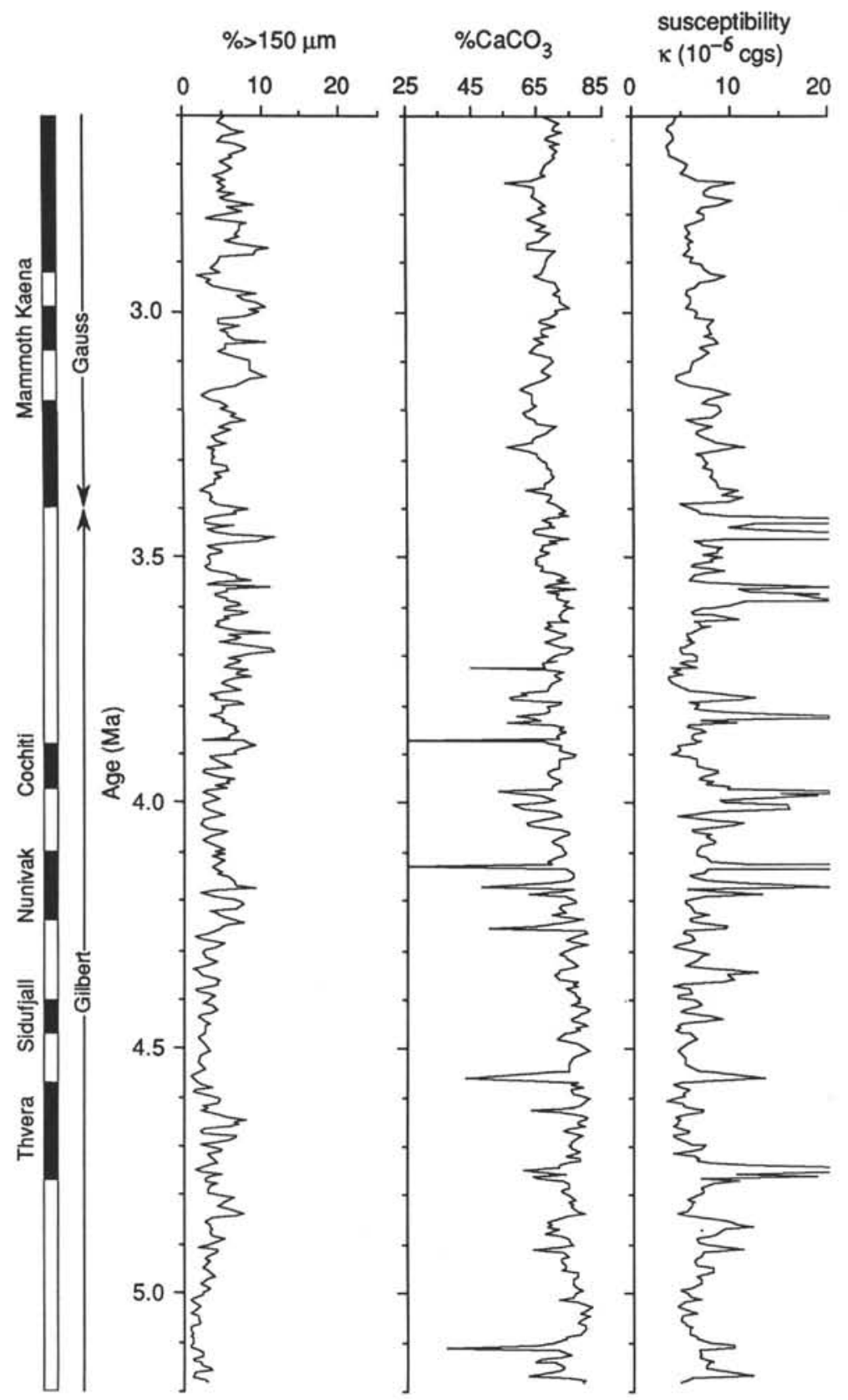

Figure 10 (continued).

at this point and will remain so until the northern Indian Ocean records and tectonic history of the Himalayas are understood in greater detail.

\section{High-Frequency Fluctuations in the Northeastern Indian Ocean (0-1 Ma)}

Over the interval from 0 to $1 \mathrm{Ma}$, the paleoenvironmental indices at Site 758 record the waxing and waning of the large Northern Hemisphere ice sheets, predominantly at a cyclicity of about 100 k.y. Glacial intervals are characterized by higher wt $\%$ coarse fraction and generally lower wt $\% \mathrm{CaCO}_{3}$ (Fig. 9). Interglacial intervals are characterized by lower wt $\%$ coarse fraction and generally higher wt $\% \mathrm{CaCO}_{3}$. High wt $\%$ coarse fraction during glacials clearly reflects enhanced $\mathrm{CaCO}_{3}$ preservation. This relationship is supported by the observation that samples with high \%coarse fraction also contain high percentages of foraminifer species which are moderate to highly susceptible to dissolution (Chen and Farrell, this volume). Likewise, samples with low wt $\%$ coarse fraction contain high abundances of foraminifer species, such as Globorotalia tumida, which are dissolution resistant. Variations in the wt $\% \mathrm{CaCO}_{3}$ and $\mathrm{CaCO}_{3} \mathrm{MAR}$ records are not in phase which suggests that dilution, rather than dissolution or productivity, controlled the late Pleistocene wt\% $\mathrm{CaCO}_{3}$ record. Higher wt $\% \mathrm{CaCO}_{3}$ during glacial stages is consistent with the scenario of Curray et al. (1982) which suggests that glacial low-stands of sea level allowed terrigenous sediments trapped on the continental shelf at the mouth of the Ganges-Brahmaputra river system to erode off the continental slope and into the basin, toward the northern Ninetyeast Ridge. During modern and interglacial times, when sea level was high, most of the terrigenous sediment was trapped in near-shore environments and the ocean basin was essentially starved of terrigenous sediment. This interpretation may require closer examination, however, in light of the recent study by Kuehl et al. (1989) which shows that 

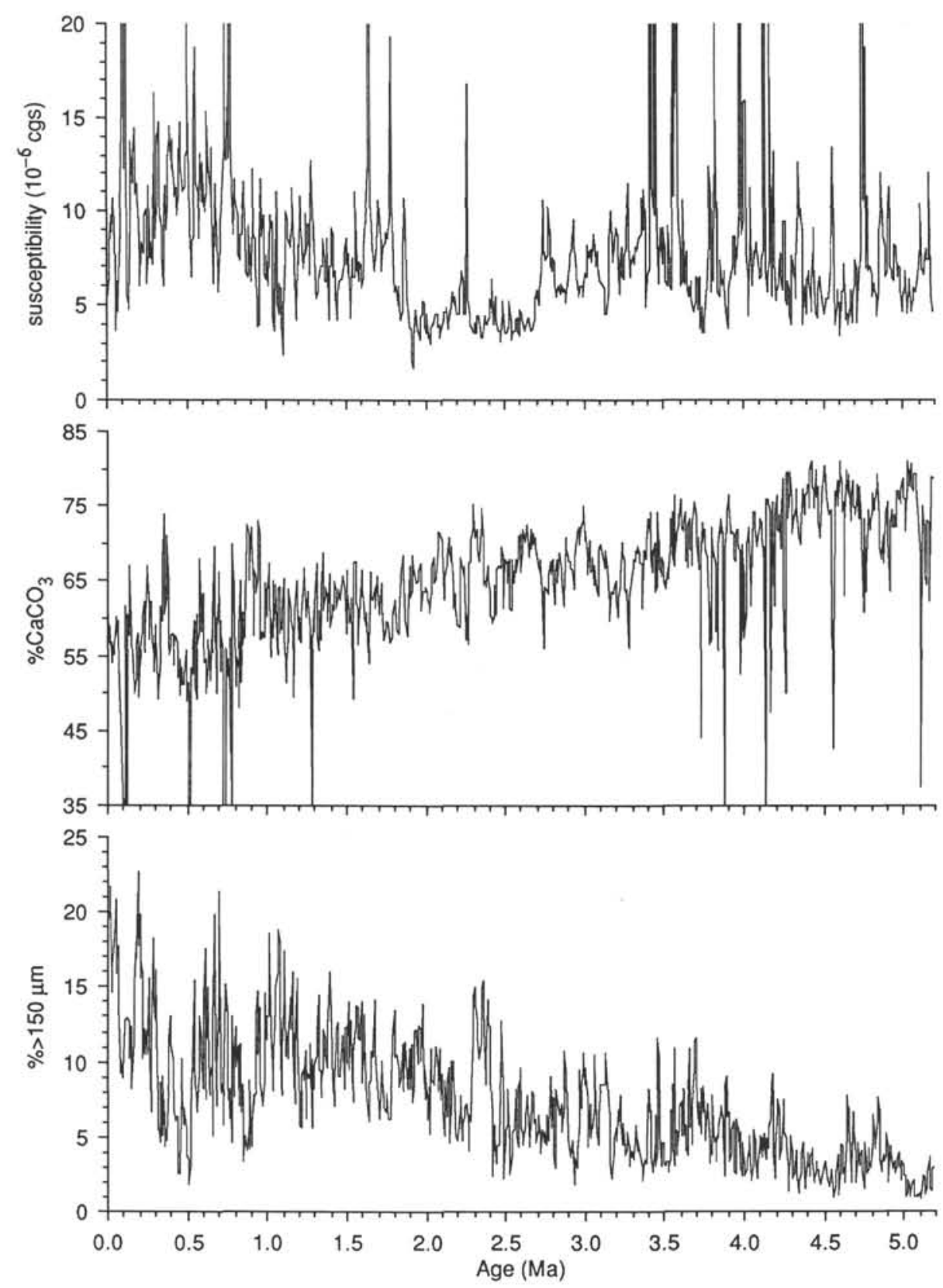

Figure 11. Site 758 composite records of magnetic susceptibility $\left(10^{-6} \mathrm{cgs}\right), \mathrm{wt} \% \mathrm{CaCO}_{3}$, and wt $\%$ coarse fraction $(>150 \mu \mathrm{m}) \mathrm{vs}$. age based on geomagnetic reversals.

modern terrigenous sediments are bypassing the delta and are flowing seaward onto the Bengal Fan.

The 100-k.y. cycles of the late Pleistocene are superimposed on the "Brunhes dissolution cycle" (Adelseck, 1977) which is most clearly observed in the wt $\%$ coarse fraction data. The midpoint of the cycle is between $400-525 \mathrm{Ka}$, where dissolution is greatest as indicated by the lowest wt\% coarse fraction. The stronger preservation events (higher wt $\%$ coarse fraction) at $\sim 700$ $\mathrm{Ka}$ and at $\sim 10 \mathrm{Ka}$ mark the beginning and end of the dissolution cycle. These times are also marked by good preservation of planktonic foraminifers (Chen and Farrell, this volume). This dissolution cycle has been observed in other Indian Ocean records from shallower and deeper waters. Fluctuations in pteropod fragmentation at Site 716 record the mid-Brunhes dissolution cycle at intermediate water depths $(540 \mathrm{~m})$ (Droxler et al., 1990). In deeper water records, from $6^{\circ} \mathrm{S}$ on the Ninetyeast Ridge, Peterson and Prell (1985b) observed the Brunhes dissolution cycle as recorded by a composite dissolution index. This cycle, which has also been observed in the Pacific (Farrell and Prell, 1989) and Atlantic (Crowley, 1985), is global in extent and appears to have affected the entire water column. The cause of this cycle and its connection to the mid-Brunhes climatic event is discussed by Jansen et al. (1986).

\section{Initiation of Significant Northern Hemisphere Glaciation Near 2.4 Ma}

The onset of glaciation in the Northern Hemisphere occurred near 2.4 Ma (Backman, 1979; Shackleton et al. 1984; Raymo et al., 1989). At this time, ice-rafted debris was deposited in the 
North Atlantic (Shackleton et al., 1984; Raymo et al., 1986) and $\delta^{18} \mathrm{O}$ records from benthic (Shackleton et al., 1984; Raymo et al., 1989 ) and planktonic (Prell, 1985) foraminifers show ${ }^{18} \mathrm{O}$-enriched intervals signifying strong glacials. At Site 758 , the sedimentary record between $2.3-2.4 \mathrm{Ma}$ is characterized by high wt $\%$ coarse fraction values, a moderate increase in $\mathrm{wt}_{\mathrm{t}} \mathrm{CaCO}_{3}$, and the glacial $\delta^{18} \mathrm{O}$ stages 96,98 , and 100 (Figs. 10 and 11). The increase in wt\% coarse fraction and wt $\% \mathrm{CaCO}_{3}$ suggests an increase in $\mathrm{CaCO}_{3}$ preservation and is similar to the preservation patterns observed in the central equatorial Pacific at this time (Farrell and Prell, in press). In the $\delta^{18} \mathrm{O}$ record from Site 758 , the three glacial stages between $2.3-2.4 \mathrm{Ma}$ are slightly enriched in 180 compared to the immediately preceding and following glacials. This enrichment, however, is not nearly as distinct as that observed in the benthic records (Shackleton et al., 1984; Raymo et al., 1989) and the planktonic record from DSDP 572 (Prell, 1985).

\section{Mid-Pleistocene Shift at $850 \mathrm{Ka}$}

The mid-Pleistocene shift in dominance of climate variance from a $\sim 40-k . y$. rhythm in the early Pleistocene to a $\sim 100-k . y$. rhythm in the late Pleistocene was first discussed by Pisias and Moore (1981) in Pacific records and was recently documented in Atlantic records by Ruddiman et al. (1989). In a statistical approach, Maasch (1988) examined many paleoclimatic records of the mid-Pleistocene transition and concluded that the transition was abrupt, and that it indicated an increase in global ice volume and a global SST cooling. Other studies (Ruddiman et al., 1986a, $1986 \mathrm{~b}, 1989)$ suggest that the transition was gradual rather than abrupt. The cause of this climatic shift remains unknown.

This mid-Pleistocene shift in dominance of climatic variance has not previously been reported in records from the Indian Ocean. The shift is clearly observed in not only the $\delta^{18} \mathrm{O}$ record from Site 758 , but also in the $\mathrm{CaCO}_{3}$ and MS records. The early Pleistocene record is characterized by higher wt $\% \mathrm{CaCO}_{3}$ (Fig. 8) and $\mathrm{CaCO}_{3}$ MAR (Fig. 5), and lower MS (Fig. 8) and non- $\mathrm{CaCO}_{3}$ MAR (Fig. 5), than in the late Pleistocene. The 40-k.y. rhythm, that of orbital obliquity, has been observed as the primary climatic rhythm of the early Pleistocene and the late Pliocene over much of the global ocean, and now the low-latitude Indian Ocean as well. Detailed age model construction and time-series analysis of these records will allow a more precise description of the timing, cyclicity, and phasing across this climatic shift.

\section{CONCLUSIONS}

1. Site 758 provides detailed, continuous records of planktonic foraminifer $\delta^{13} \mathrm{C}, \delta^{18} \mathrm{O}$, wt $\% \mathrm{CaCO}_{3}$, wt $\%$ coarse fraction, MS, and geomagnetic reversals for the Plio-Pleistocene.

2. The MS stratigraphy from Site 758 is extremely useful for correlating between holes, identifying recovery gaps, locating ash layers, and constructing a continuous composite depth section.

3. Despite core recovery in excess of $100 \%$, about $12 \%$ of the late Neogene sedimentary sequence was not recovered in each of the two holes at Site 758 . As much as $2.7 \mathrm{~m}$ of sediment was lost at nearly every core break. If Site 758 had not been cored twice and logged for magnetic susceptibility, the missing sediment would have been very difficult to identify. By splicing between the two holes, a continuous composite depth section was constructed for the uppermost $116 \mathrm{mbsf}$ at Site 758 , which spans from 0.0 to $7.3 \mathrm{Ma}$.

4. Identification of $\delta^{18} \mathrm{O}$ stages 1 through 105 provides a high-resolution age model, permits detailed correlation to other ODP sites, and attests to the completeness of the sedimentary record at Site 758 . The $\delta^{18} \mathrm{O}$ record shows (1) the glacial stages associated with the initiation of significant Northern Hemisphere; (2) the mid-Pleistocene transition (between $\delta^{18} \mathrm{O}$ stages 25 and
22 ) in variance dominance from $\sim 40 \mathrm{k} . \mathrm{y}$. in the late Pliocene and early Pleistocene to $\sim 100$ k.y. in the late Pleistocene; and (3) the standard sequence of 19 high-amplitude $\delta^{18} \mathrm{O}$ stages in the Brunhes Chron. At Site 758 , the relative ${ }^{18} \mathrm{O}$ enrichment of the glacial stages between $2.4 \mathrm{Ma}$ and $2.3 \mathrm{Ma}$ is not as great as the relative enrichment seen in benthic records from the North Atlantic (Shackleton et al., 1984; Raymo et al., 1989).

5. Preliminary interpretation of the sedimentary records suggests that (1) long-term variations in the $\mathrm{CaCO}_{3}$ and MS are primarily controlled by terrigenous dilution and $\mathrm{CaCO}_{3}$ productivity; (2) the long-term increase in non- $\mathrm{CaCO}_{3}$ (terrigenous) accumulation is attributed to greater riverine input through complex tectonic and climatic factors such as increased rates of uplift of the Himalayas and intensification of the orogenic monsoonal rains; (3) the monotonic increase in wt \% coarse fraction since 5 Ma represents a gradual increase in $\mathrm{CaCO}_{3}$ preservation; (4) the mid-Pleistocene shift toward lower wt $\% \mathrm{CaCO}_{3}$ and higher MS coincides with the shift in $\delta^{18} \mathrm{O}$ variability, supporting the contention that the climate and ocean systems underwent a fundamental change at that time; and (5) during the late Pleistocene, $\mathrm{CaCO}_{3}$ dissolution increased during interglacials and decreased during interglacials. This $\sim 100-k . y$. pattern is superimposed on the Brunhes dissolution cycle which extends from $\sim 700$ to $\sim 10 \mathrm{Ka}$.

6. Tephra layers occur throughout the Plio-Pleistocene and record the volcanic history of the Indonesian arc. These layers are useful lithostratigraphic and potentially chronostratigraphic markers.

\section{ACKNOWLEDGMENTS}

The authors are most grateful to Jiajie Chen, Min-Te Chen, Bob Fifer, Wei Kang, Karen Kohfeld, April Martin, Tulshi Saha, and Jack S. Vietas for their hard work and expert technical assistance, without which this study would have been impossible. We thank Jeffrey Gee, David Murray, and Maureen Raymo for useful comments and suggestions. The manuscript benefitted by thoughtful reviews from James Cullen, Larry Peterson, and Elliot Taylor. This work was supported by grants from JOI/USSAC (TAMRF-20244) and NSF/OCE 8911874 (D. W. Murray and J. W. Farrell),

\section{REFERENCES}

Adelseck, C. G., Jr., 1977. Recent and late Pleistocene sediments from the eastern equatorial Pacific Ocean: sedimentation and dissolution [Ph.D. dissert.]. Univ. of California, San Diego.

Alexandrovich, J. M., and Hays, J. D., 1989. High-resolution stratigraphic correlation of ODP Leg 111 Holes 677A and 677B and DSDP Leg 69 Hole 504. In Becker, K., Sakai, H., et al., Proc. ODP, Sci. Results, 111: College Station, TX (Ocean Drilling Program), 263-276.

Backman, J., 1979. Pliocene biostratigraphy of DSDP Sites 111 and 116 from the North Atlantic Ocean and the age of the Northern Hemisphere Glaciation. Stockholm Contrib. Geol., 32:115-137.

Berger, W. H., 1970. Planktonic foraminifera: selective solution and the lysocline. Mar. Geol., 8:111-138.

Berger, W. H., Bonneau, M.-C., and Parker, F. L., 1982. Foraminifera on the deep-sea floor: lysocline and dissolution rate. Oceanol. Acta, 5:249-258.

Berger, W. H., Killingley, J. S., and Vincent, E., 1978. Stable isotopes in deep-sea carbonates: box core ERDC-92, west equatorial Pacific. Oceanol. Acta, 1:203-216.

Bouquillon, A., Chamley, H., and Fröhlich, F., 1989. Sédimentation argileuse au Cénozoïque supérieur dans l'Océan Indien nord-oriental. Oceanol. Acta, 12:133-147.

Craig, H., 1957. Isotopic standards for carbon and oxygen correction factors for mass spectrometric analysis of $\mathrm{CO}_{2}$. Geochim. Cosmochim. Acta, 12:133-149.

Crowley, T. J., 1985. Late Quaternary carbonate changes in the North Atlantic, and Atlantic-Pacific comparisons. In Sundquist, E. T., and Broecker, W. S. (Eds.), The Carbon Cycle and Atmospheric $\mathrm{CO}_{2}$ : 
Natural Variations, Archaen to Present. Am. Geophys. Union Monogr., 32:271-284.

Curray, J. R., Emmel, F. J., Moore, D. G., and Raitt, R. W., 1982. Structure, tectonics and geological history of the northeastern Indian Ocean. In Nairn, A.E.M., and Stehli, F. G. (Eds.), The Ocean Basins and Margins (Vol. 6): New York (Plenum), 399-450.

Curry, W. B., and Matthews, R. K., 1981. Equilibrium ${ }^{18} \mathrm{O}$ fractionation in small size fraction planktic foraminifera: evidence from Recent Indian Ocean sediments. Mar. Micropaleontol., 6:327-337.

deMenocal, P., and Bloemendal, J., in press. Episodes in the late Neogene evolution of the Asian monsoon: evidence from Leg 117 magnetic susceptibility data. In Prell, W. L., Niitsuma, N., et al., Proc. ODP, Sci. Results, 117: College Station, TX (Ocean Drilling Program).

Emerson, S., and Bender, M., 1981. Carbon fluxes at the sediment-water interface of the deep-sea: calcium carbonate preservation. J. Mar. Res., 39:139-162.

Farrell, J. W., and Prell, W. L., 1989. Climatic change and $\mathrm{CaCO}_{3}$ preservation: an 800,000 year bathymetric reconstruction from the central equatorial Pacific Ocean. Paleoceanography, 4:447-466. in press. Pacific $\mathrm{CaCO}_{3}$ preservation and $\delta^{18} \mathrm{O}$ since $4 \mathrm{Ma}$ : paleoceanic and paleoclimatic implications. Paleoceanography.

Imbrie, J., Hays, J. D., Martinson, D. G., McIntyre, A., Mix, A. C., Morley, J. J., Pisias, N. G., Prell, W. L., and Shackleton, N. J., 1984. The orbital theory of Pleistocene climate: support from a revised chronology of the marine delta $\delta^{18} \mathrm{O}$ record. In Berger, A., Imbrie, J., Hays, J., Kukla, G., and Saltzman, B. (Eds.), Milankovitch and Climate (Pt. 1): Dordrecht (D. Reidel), 269-305.

Jansen, J.H.F., Kuijpers, A., and Troelstra, S. R., 1986. A mid-Brunhes climatic event: long-term changes in global atmospheric and ocean circulation. Science, 232:619-622.

Jones, G. A., and Kaiteris, P., 1983, A vacuum-gasometric technique for rapid and precise analysis of calcium carbonate in sediments and soils. J. Sediment. Petrol., 53:655-660.

Kolla, V., Moore, D. G., and Curray, J. R., 1976. Recent bottom-current activity in the deep western Bay of Bengal. Mar. Geol., 21:255-270.

Kuehl, S. A., Hariu, T. M., and Moore, W. S., 1989. Shelf sedimentation off the Ganges-Brahmaputra river system: evidence for sediment bypassing to the Bengal Fan. Geology, 17:1132-1135.

Maasch, K. A., 1988. Statistical detection of the mid-Pleistocene transition. Clim. Dyn., 2:133-143

McDougall, I., and Harrison, T. M., 1988. Geochronology and Thermochronology by the ${ }^{40} \mathrm{Ar} /{ }^{39} \mathrm{Ar}$ Method. Oxford Monogr. Geol. Geophys., 9.

Milliman, J. D., and Meade, R. H., 1983. World delivery of river sediment to the oceans. J. Geol., 91:1-21.

Murray, D., and Prell, W. L., in press. Pliocene to Pleistocene variations in calcium carbonate, organic carbon, and opal on the Owen Ridge, Northern Arabian Sea. In Prell, W. L., Niitsuma, N., et al., Proc. ODP, Sci. Results, 117: College Station, TX (Ocean Drilling Program).

Peirce, J., Weissel, J., et al., 1989. Proc. ODP, Init. Repts., 121: College Station, TX (Ocean Drilling Program).

Peterson, L. C., and Backman, J., 1990. Late Cenozoic carbonate accumulation and the history of the carbonate compensation depth in the western equatorial Indian Ocean. In Duncan, R. A., Backman, J., Peterson, L. C., et al., Proc. ODP, Sci. Results, 115: College Station, TX (Ocean Drilling Program), 467-507.

Peterson, L. C., and Prell, W. L., 1985a. Carbonate dissolution in Recent sediments of the eastern equatorial Indian Ocean: preservation patterns and carbonate loss above the lysocline. Mar. Geol., 64:259-290.

1985b. Carbonate preservation and rates of climatic change: an $800 \mathrm{kyr}$ record from the Indian Ocean. In Sundquist, E. T., and Broecker, W. S. (Eds.), The Carbon Cycle and Atmospheric $\mathrm{CO}_{2}$ : Natural Variations Archean to Present: Am. Geophys. Union Monogr., 32:251-270.

Pisias, N. G., and Moore, T. C., Jr., 1981. The evolution of Pleistocene climate: a time series approach. Earth Planet. Sci. Lett., 52:450-456.

Prell, W. L., 1985. Pliocene stable isotope and carbonate stratigraphy (Holes 572C and 573A): paleoceanographic data bearing on the question of Pliocene glaciation. In Mayer, L., and Theyer, F., Thomas, E., Init. Repts. DSDP, 85: Washington (U.S. Govt. Printing Office), 723-734.
Prell, W. L., Imbrie, J., Martinson, D. G., Morley, J. J., Pisias, N. G., Shackleton, N. J., and Streeter, H. F., 1986. Graphic correlation of oxygen isotope stratigraphy application to the late Quaternary. Paleoceanography, 1:137-162.

Prell, W. L., Niitsuma, N., et al., 1989. Proc. ODP, Init. Repts., 117: College Station, TX (Ocean Drilling Program).

Prospero, J. M., 1981. Arid regions as sources of mineral aerosols in the marine atmosphere. In Pewe, T. L. (Ed.), Desert Dust: Origin, Characteristics, and Effects on Man: Spec. Pap. Geol. Soc. Am., 186:7186.

Raymo, M. E., Ruddiman, W. F., Backman, J., Clement, B. M., and Martinson, D. G., 1989. Late Pliocene variation in Northern Hemisphere ice sheets and North Atlantic deep water circulation. Paleoceanography, 4:413-446.

Raymo, M. E., Ruddiman, W. F., Froelich, P. N., 1988. Influence of late Cenozoic mountain building on ocean geochemical cycles. Geology, 16:649-653.

Robinson, S. G., 1990. Applications for whole-core magnetic susceptibility measurements of deep-sea sediments: Leg 115 results. In Duncan, R. A., Backman, J., Peterson, L. C., et al., Proc. ODP, Sci. Results, 115: College Station, TX (Ocean Drilling Program), 737-771.

Ruddiman, W. F., Cameron, D., and Clement, B. M., 1987. Sediment disturbance and correlation of offset holes drilled with the hydraulic piston corer: Leg 94. In Ruddiman, W. F., Kidd, R. B., Thomas, E., et al., Init. Repts. DSDP, 94 (Pt. 2): Washington (U.S. Govt. Printing Office), 615-634.

Ruddiman, W. F., Raymo, M. E., Martinson, D. G., Clement, B. M., and Backman, J., 1989. Pleistocene evolution: Northern Hemisphere ice sheets and North Atlantic Ocean. Paleoceanography, 4:353-412.

Ruddiman, W. F., Raymo, M. E., and McIntyre, A., 1986a. Matuyama 41,000-year cycles: North Atlantic and Northern Hemisphere ice sheets. Earth Planet. Sci. Lett., 80:117-129.

Ruddiman, W. F., Shackleton, N. J., and McIntyre, A., 1986b. North Atlantic sea-surface temperatures for the last 1.1 million years. In Summerhays, C. P., and Shackleton, N. J. (Eds.), North Atlantic Paleoceanography. Geol. Soc. Am. Spec. Publ., 21:155-173.

Schmitz, B., 1987. The $\mathrm{TiO}_{2} / \mathrm{Al}_{2} \mathrm{O}_{3}$ ratio in the Cenozoic Bengal Abyssal Fan sediments and its use as a paleostream energy indicator. Mar. Geol., 76:195-206.

Shackleton, N. J., Backman, J., Zimmerman, H., Kent, D. V., Hall, M. A., Roberts, D. G., Schnitker, D., Baldauf, J., Desprairies, A., Homrighausen, R., Huddlestun, P., Keene, J. B., Kaltenback, A. J., Krumsiek, K.A.O., Morton, A. C., Murray, J. W., and Westberg-Smith, J., 1984. Oxygen isotope calibration of the onset of ice-rafting in DSDP Site 552A: history of glaciation in the North Atlantic region. Nature, 307:620-623.

Shackleton, N. J., Berger, A., and Peltier, W. R., in press. An alternative astronomical calibration of the Lower Pleistocene timescale based on ODP Site 677. Trans. R. Soc. Edinburgh.

Shackleton, N. J., and Hall, M. A., 1989. Stable isotope history of the Pleistocene at ODP Site 677. In Becker, K., Sakai, H., et al., Proc. ODP, Sci. Results, 111: College Station, TX (Ocean Drilling Program), 295-316.

1990. Pliocene oxygen isotope stratigraphy of Hole 709C. In Duncan, R. A., Backman, J., Peterson, L. C., et al., Proc. ODP, Sci. Results, 115: College Station, TX (Ocean Drilling Program), 529538.

Shipboard Scientific Party, 1989. Site 758. In Peirce, J., Weissel, J., Proc. ODP, Init.Repts., 121: College Station, TX (Ocean Drilling Program), 359-453.

Stow, D.A.V., Amano, K., Balson, P. S., Brass, G. W., Corrigan, J., Raman, C. V., Tiercelin, J.-J., Townsend, M., and Wijayananda, N. P., 1990. Sediment facies and processes on the Distal Bengal Fan, Leg 116. In Cochran, J. R., Stow, D.A.V., et al., Proc. ODP, Sci. Results, 116: College Station, TX (Ocean Drilling Program), 377-396.

Thompson, R., and Oldfield, F., 1986. Environmental Magnetism: London (Allen and Unwin).

Date of initial receipt: 7 March 1990

Date of acceptance: 19 November 1990

Ms 121B-124 
APPENDIX A

Comparison of $\mathrm{Wt}_{\mathrm{C}} \mathrm{CaCO}_{3}$ Data Generated at Brown University and ODP Shipboard Laboratories

\begin{tabular}{|c|c|c|c|c|c|c|c|c|}
\hline $\begin{array}{l}\text { Core, section, } \\
\text { interval }(\mathrm{cm})\end{array}$ & $\begin{array}{l}\text { ODP } \\
\text { depth } \\
\text { (mbsf) }\end{array}$ & $\begin{array}{c}\text { 1st Brown } \\
\text { Wt } \% \mathrm{CaCO}_{3} \\
\text { analysis }\end{array}$ & $\begin{array}{l}\text { 2nd Brown } \\
\mathrm{Wt} \% \mathrm{CaCO}_{3} \\
\text { analysis }\end{array}$ & $\begin{array}{c}\text { 3rd Brown } \\
\text { Wt } \% \mathrm{CaCO}_{3} \\
\text { analysis }\end{array}$ & $\begin{array}{l}\mathrm{Wt} \% \mathrm{CaCO}_{3} \\
\text { half range }{ }^{\mathrm{a}^{3}}\end{array}$ & $\begin{array}{c}\text { Mean } \\
\text { Brown } \\
\text { Wt } \% \mathrm{CaCO}_{3}\end{array}$ & $\begin{array}{c}\text { Shipboard } \\
\mathrm{Wt} \% \mathrm{CaCO}_{3}\end{array}$ & $\begin{array}{c}\text { Shipboard-Brown } \\
\mathrm{CaCO}_{3} \\
\text { difference }\end{array}$ \\
\hline \multicolumn{9}{|l|}{ 121- } \\
\hline $758 \mathrm{C}-1 \mathrm{H}-1,115-117$ & 1.15 & 59.6 & 59.7 & & 0.0 & 59.6 & 61.5 & 1.9 \\
\hline $758 \mathrm{C}-1 \mathrm{H}-2,45-47$ & 1.95 & 63.9 & 62.9 & & 0.5 & 63.4 & 64.2 & 0.8 \\
\hline $758 \mathrm{C}-1 \mathrm{H}-2,115-117$ & 2.65 & 59.7 & 58.1 & & 0.8 & 58.9 & 59.0 & 0.1 \\
\hline $758 \mathrm{~B}-1 \mathrm{H}-2,128-130$ & 2.78 & 60.1 & 59.1 & & 0.5 & 59.6 & 59.6 & 0.0 \\
\hline $758 \mathrm{C}-1 \mathrm{H}-3,45-47$ & 3.45 & 58.6 & 59.1 & & 0.2 & 58.9 & 61.2 & 2.3 \\
\hline $758 \mathrm{C}-1 \mathrm{H}-3,115-117$ & 4.15 & 56.3 & 57.4 & & 0.6 & 56.8 & 57.3 & 0.5 \\
\hline $758 \mathrm{C}-1 \mathrm{H}-4,45-47$ & 4.95 & 62.0 & 61.7 & & 0.2 & 61.8 & 63.6 & 1.8 \\
\hline $758 \mathrm{C}-1 \mathrm{H}-4,115-117$ & 5.65 & 50.5 & 50.5 & & 0.0 & 50.5 & 52.2 & 1.7 \\
\hline $758 \mathrm{~B}-1 \mathrm{H}-4,129-131$ & 5.79 & 51.5 & 50.4 & & 0.6 & 51.0 & 51.1 & 0.1 \\
\hline $758 \mathrm{C}-1 \mathrm{H}-5,45-47$ & 6.45 & 61.7 & 62.0 & & 0.2 & 61.8 & 62.6 & 0.8 \\
\hline $758 \mathrm{C}-1 \mathrm{H}-5,115-117$ & 7.15 & 59.3 & 58.6 & & 0.4 & 58.9 & 59.3 & 0.4 \\
\hline $758 \mathrm{C}-1 \mathrm{H}-6,45-47$ & 7.95 & 61.8 & 61.8 & & 0.0 & 61.8 & 63.8 & 2.0 \\
\hline $758 \mathrm{C}-1 \mathrm{H}-6,115-117$ & 8.65 & 58.3 & 58.3 & & 0.0 & 58.3 & 58.7 & 0.4 \\
\hline 758B-1H-6, 130-132 & 8.80 & .52 .7 & 52.3 & & 0.2 & 52.5 & 51.9 & -0.6 \\
\hline 758B-2H-2, 90-92 & 11.90 & 64.4 & 63.5 & & 0.5 & 63.9 & 64.4 & 0.5 \\
\hline 758B-2H-5, 90-92 & 16.40 & 65.1 & 66.2 & 63.4 & 1.4 & 64.9 & 64.8 & -0.1 \\
\hline 758B-2H-7, 38-40 & 18.88 & 56.5 & 56.3 & & 0.1 & 56.4 & 57.2 & 0.8 \\
\hline $758 \mathrm{~B}-3 \mathrm{H}-2,125-127$ & 21.65 & 59.3 & 58.5 & & 0.4 & 58.9 & 60.6 & 1.7 \\
\hline $758 \mathrm{~B}-3 \mathrm{H}-4,125-127$ & 24.65 & 65.9 & 64.3 & 64.9 & 0.8 & 65.0 & 66.1 & 1.1 \\
\hline $758 \mathrm{~B}-3 \mathrm{H}-6,125-127$ & 27.65 & 68.9 & 67.5 & & 0.7 & 68.2 & 68.3 & 0.1 \\
\hline $758 \mathrm{~A}-4 \mathrm{H}-3,25-27$ & 28.45 & 64.5 & 65.8 & & 0.6 & 65.1 & 65.5 & 0.4 \\
\hline $758 \mathrm{~B}-4 \mathrm{H}-1,125-127$ & 29.65 & 65.3 & 66.0 & & 0.4 & 65.6 & 68.4 & 2.8 \\
\hline $758 \mathrm{~B}-4 \mathrm{H}-3,125-127$ & 32.65 & 65.4 & 68.1 & & 1.4 & 66.8 & 70.0 & 3.3 \\
\hline $758 \mathrm{~B}-4 \mathrm{H}-5,125-127$ & 35.65 & 68.1 & 67.5 & & 0.3 & 67.8 & 69.2 & 1.4 \\
\hline 758B-4H-7, 34-36 & 37.74 & 70.7 & 69.7 & & 0.5 & 70.2 & 71.5 & 1.3 \\
\hline $758 \mathrm{~B}-5 \mathrm{H}-4,125-127$ & 43.75 & 60.4 & 57.9 & & 1.2 & 59.2 & 59.8 & 0.6 \\
\hline 758B-5H-7, 55-57 & 47.55 & 76.8 & 76.6 & & 0.1 & 76.7 & 76.9 & 0.2 \\
\hline $758 \mathrm{~B}-6 \mathrm{H}-2,125-127$ & 50.45 & 73.8 & 70.4 & 74.9 & 2.2 & 73.0 & 73.1 & 0.1 \\
\hline $758 \mathrm{~B}-6 \mathrm{H}-4,125-127$ & 53.45 & 75.2 & 73.9 & & 0.7 & 74.6 & 75.9 & 1.3 \\
\hline $758 \mathrm{~B}-6 \mathrm{H}-6,125-127$ & 56.45 & 68.3 & 67.6 & & 0.4 & 67.9 & 69.7 & 1.8 \\
\hline 758B-7H-1, 55-57 & 57.85 & 71.2 & 71.4 & & 0.1 & 71.3 & 73.4 & 2.1 \\
\hline 758B-7H-3, 55-57 & 60.85 & 79.2 & 79.4 & & 0.1 & 79.3 & 80.6 & 1.3 \\
\hline 758B-7H-5, 55-57 & 63.85 & 81.0 & 80.5 & & 0.3 & 80.8 & 82.1 & 1.3 \\
\hline $758 \mathrm{~B}-7 \mathrm{H}-7,55-57$ & 66.85 & 73.5 & 71.2 & & 1.2 & 72.4 & 73.2 & 0.8 \\
\hline $758 \mathrm{~B}-8 \mathrm{H}-4,55-57$ & 72.05 & 77.5 & 77.3 & & 0.1 & 77.4 & 78.0 & 0.6 \\
\hline $758 \mathrm{~B}-8 \mathrm{H}-6,55-57$ & 75.05 & 75.9 & 75.1 & & 0.4 & 75.5 & 77.5 & 2.0 \\
\hline $758 \mathrm{~A}-26 \mathrm{R}-4,95-97$ & 243.15 & 88.1 & 88.2 & & 0.1 & 88.1 & 88.8 & 0.7 \\
\hline $758 \mathrm{~A}-27 \mathrm{R}-1,95-97$ & 248.25 & 87.2 & 87.4 & 88.1 & 0.4 & 87.6 & 89.7 & 2.1 \\
\hline
\end{tabular}

${ }^{a}$ Half range is one-half of the range between the two (or three) wt $\% \mathrm{CaCO}_{3}$ analyses.

Note: Number of comparisons of Brown vs. shipboard data $=38.0$; sum of the differences $=38.5$; average difference $=1.0$; sum of the absolute values of the differences $=41.8$; average absolute difference $=1.1$; average half range of Brown results $=0.5$. 
APPENDIX B

Wt $\% \mathrm{CaCO}_{3}$, Wt \% Coarse Fraction, and Dry-Bulk Density Data From Hole 758A

\begin{tabular}{|c|c|c|c|c|c|c|c|}
\hline $\begin{array}{l}\text { Core, section, } \\
\text { interval }(\mathrm{cm})\end{array}$ & $\begin{array}{l}\text { ODP } \\
\text { depth } \\
\text { (mbsf) }\end{array}$ & $\begin{array}{l}\text { Composite } \\
\text { depth } \\
\text { (m) }\end{array}$ & $\begin{array}{c}\text { Mean } \\
w t \% \mathrm{CaCO}_{3}\end{array}$ & $\begin{array}{c}\text { Number } \\
\text { of wt \% CaCO } \\
\text { analyses }\end{array}$ & $\begin{array}{c}\text { Coarse } \\
\text { fraction } \\
\text { (wt } \%>150 \mu \mathrm{m})\end{array}$ & $\begin{array}{c}\text { Dry-bulk } \\
\text { density } \\
\left(\mathrm{g} / \mathrm{cm}^{3}\right)\end{array}$ & Comment \\
\hline \multicolumn{8}{|l|}{$121-758 \mathrm{~A}-$} \\
\hline $1 \mathrm{H}-1,1$ & 0.01 & 0.01 & 64.63 & 2 & 28.490 & 0.527 & \\
\hline $1 \mathrm{H}-1,11$ & 0.11 & 0.11 & 61.67 & 2 & 19.327 & 0.542 & \\
\hline $1 \mathrm{H}-1,21$ & 0.21 & 0.21 & 56.96 & 1 & 20.014 & 0.599 & \\
\hline $1 \mathrm{H}-1,31$ & 0.31 & 0.31 & 58.88 & 1 & 21.678 & 0.656 & \\
\hline $1 \mathrm{H}-1,41$ & 0.41 & 0.41 & 54.06 & 2 & 14.596 & 0.656 & \\
\hline $1 \mathrm{H}-1,51$ & 0.51 & 0.51 & 56.75 & 1 & 16.124 & 0.613 & \\
\hline $1 \mathrm{H}-1,61$ & 0.61 & 0.61 & 55.03 & 2 & 18.246 & 0.691 & \\
\hline $1 \mathrm{H}-1,71$ & 0.71 & 0.71 & 55.51 & 1 & 17.971 & 0.656 & \\
\hline $1 \mathrm{H}-1,81$ & 0.81 & 0.81 & 59.07 & 1 & 20.852 & 0.648 & \\
\hline $1 \mathrm{H}-1,91$ & 0.91 & 0.91 & 60.25 & 1 & 15.847 & 0.741 & \\
\hline $1 \mathrm{H}-1,101$ & 1.01 & 1.01 & 57.70 & 1 & 16.736 & 0.670 & \\
\hline $1 \mathrm{H}-1,111$ & 1.11 & 1.11 & 59.68 & 1 & 17.727 & 0.691 & \\
\hline $1 \mathrm{H}-1,121$ & 1.21 & 1.21 & 54.27 & 1 & 14.036 & 0.656 & \\
\hline $1 \mathrm{H}-1,131$ & 1.31 & 1.31 & 45.48 & 1 & 9.268 & 0.670 & \\
\hline $1 \mathrm{H}-1,141$ & 1.41 & 1.41 & 45.20 & 1 & 10.116 & 0.762 & \\
\hline $1 \mathrm{H}-2,1$ & 1.51 & 1.51 & 35.73 & 2 & 8.883 & 0.787 & Contains some ash $\mathrm{A}$ \\
\hline $1 \mathrm{H}-2,11$ & 1.61 & 1.61 & 3.64 & 1 & & 0.997 & Ash A, not processed \\
\hline $1 \mathrm{H}-2,2 \mathrm{I}$ & 1.71 & 1.71 & 2.70 & 1 & & 0.898 & Ash A, not processed \\
\hline $1 \mathrm{H}-2,31$ & 1.81 & 1.81 & 4.21 & 1 & & 0.819 & Ash $\mathrm{A}$, not processed \\
\hline $1 \mathrm{H}-2,41$ & 1.91 & 1.91 & 61.67 & 2 & 12.791 & 0.727 & \\
\hline $1 \mathrm{H}-2,51$ & 2.01 & 2.01 & 9.53 & 1 & & 0.969 & Ash B, not processed \\
\hline $1 \mathrm{H}-2,61$ & 2.11 & 2.11 & 60.48 & 1 & 12.907 & 0.720 & \\
\hline $1 \mathrm{H}-2,71$ & 2.21 & 2.21 & 57.76 & 1 & 12.602 & 0.755 & \\
\hline $1 \mathrm{H}-2,81$ & 2.31 & 2.31 & 67.15 & 2 & 10.231 & 0.777 & \\
\hline $1 \mathrm{H}-2,91$ & 2.41 & 2.41 & 58.98 & 1 & 12.290 & 0.769 & \\
\hline $1 \mathrm{H}-2,101$ & 2.51 & 2.51 & 57.66 & 1 & 9.939 & 0.755 & \\
\hline $1 \mathrm{H}-2,111$ & 2.61 & 2.61 & 57.40 & 1 & 8.271 & 0.769 & \\
\hline $1 \mathrm{H}-2,121$ & 2.71 & 2.71 & 51.61 & 1 & 10.927 & 0.755 & \\
\hline $1 \mathrm{H}-2,131$ & 2.81 & 2.81 & 50.19 & 1 & 14.889 & 0.705 & \\
\hline $1 \mathrm{H}-2,141$ & 2.91 & 2.91 & 51.83 & 1 & 18.070 & 0.784 & \\
\hline $1 \mathrm{H}-3,1$ & 3.01 & 3.01 & 56.24 & 1 & 16.867 & 0.798 & \\
\hline $1 \mathrm{H}-3,11$ & 3.11 & 3.11 & 57.90 & 1 & 22.754 & 0.755 & \\
\hline $1 \mathrm{H}-3,21$ & 3.21 & 3.21 & 49.60 & 2 & 17.814 & 0.698 & \\
\hline $1 \mathrm{H}-3,31$ & 3.31 & 3.31 & 54.77 & 1 & 19.874 & 0.741 & \\
\hline $1 \mathrm{H}-3,41$ & 3.41 & 3.41 & 54.65 & 1 & 15.589 & 0.784 & \\
\hline $1 \mathrm{H}-3,51$ & 3.51 & 3.51 & 55.76 & 1 & 16.851 & 0.755 & \\
\hline $1 \mathrm{H}-3,61$ & 3.61 & 3.61 & 57.95 & 1 & 15.990 & 0.755 & \\
\hline $1 \mathrm{H}-3,71$ & 3.71 & 3.71 & 60.11 & 1 & 10.177 & 0.812 & \\
\hline $1 \mathrm{H}-3,81$ & 3.81 & 3.81 & 62.37 & 1 & 12.147 & 0.805 & \\
\hline $1 \mathrm{H}-3,91$ & 3.91 & 3.91 & 55.54 & 2 & 10.532 & 0.812 & \\
\hline $1 \mathrm{H}-3,101$ & 4.01 & 4.01 & 65.38 & 1 & 12.006 & 0.812 & \\
\hline $1 \mathrm{H}-3,111$ & 4.11 & 4.11 & 67.08 & 1 & 10.460 & 0.769 & \\
\hline $1 \mathrm{H}-3,121$ & 4.21 & 4.21 & 62.28 & 1 & 15.656 & 0.741 & \\
\hline $1 \mathrm{H}-3,131$ & 4.31 & 4.31 & 57.23 & 1 & 14.323 & 0.727 & \\
\hline $1 \mathrm{H}-3,141$ & 4.41 & 4.41 & 59.30 & 1 & 12.016 & 0.855 & \\
\hline $1 \mathrm{H}-4,1$ & 4.51 & 4.51 & 62.19 & 1 & 6.742 & 0.778 & \\
\hline $1 \mathrm{H}-4,11$ & 4.61 & 4.61 & 60.07 & 1 & 11.220 & 0.741 & \\
\hline $1 \mathrm{H}-4,21$ & 4.71 & 4.71 & 55.52 & 2 & 18.392 & 0.698 & \\
\hline $1 \mathrm{H}-4,31$ & 4.81 & 4.81 & 53.02 & 1 & 14.643 & 0.734 & \\
\hline $1 \mathrm{H}-4,41$ & 4.91 & 4.91 & 57.60 & 1 & 12.776 & 0.812 & \\
\hline $1 \mathrm{H}-4,51$ & 5.01 & 5.01 & 59.01 & 1 & 14.115 & 0.769 & \\
\hline $1 \mathrm{H}-4,61$ & 5.11 & 5.11 & 58.68 & 1 & 16.238 & 0.727 & \\
\hline $1 \mathrm{H}-4,71$ & 5.21 & 5.21 & 50.51 & 1 & 9.136 & 0.755 & \\
\hline $1 \mathrm{H}-4,81$ & 5.31 & 5.31 & 49.31 & 2 & 5.605 & 0.791 & Tie point \\
\hline $1 \mathrm{H}-4,91$ & 5.41 & 5.41 & 55.80 & i & 6.603 & 0.777 & Not in composite \\
\hline $1 \mathrm{H}-4,101$ & 5.51 & 5.51 & 57.46 & 1 & 5.842 & 0.798 & Not in composite \\
\hline $1 \mathrm{H}-4,111$ & 5.61 & 5.61 & 62.56 & 1 & 7.326 & 0.741 & Not in composite \\
\hline $1 \mathrm{H}-4,121$ & 5.71 & 5.71 & 70.52 & 1 & 5.925 & 0.798 & Not in composite \\
\hline IH-CC, 1 & 5.76 & 5.76 & 72.81 & 1 & 6.573 & 0.762 & Not in composite \\
\hline 1H-CC, 11 & 5.86 & 5.86 & 65.63 & 1 & 5.956 & 0.869 & Not in composite \\
\hline $1 \mathrm{H}-\mathrm{CC}, 21$ & 5.96 & 5.96 & 60.25 & 1 & 7.640 & 0.762 & Not in composite \\
\hline $2 \mathrm{H}-1,1$ & 6.01 & 7.43 & 49.89 & 1 & 2.681 & 0.742 & Tie point \\
\hline $2 \mathrm{H}-1,11$ & 6.11 & 7.53 & 54.57 & 1 & 2.569 & 0.712 & \\
\hline $2 \mathrm{H}-1,21$ & 6.21 & 7.63 & 51.28 & 1 & 8.465 & 0.798 & \\
\hline $2 \mathrm{H}-1,31$ & 6.31 & 7.73 & 53.41 & 1 & 10.174 & 0.727 & \\
\hline $2 \mathrm{H}-1,41$ & 6.41 & 7.83 & 51.59 & i & 7.881 & 0.712 & \\
\hline $2 \mathrm{H}-1,51$ & 6.51 & 7.93 & 51.08 & i & 5.835 & 0.784 & \\
\hline $2 \mathrm{H}-1,61$ & 6.61 & 8.03 & 52.04 & 1 & 6.967 & 0.755 & \\
\hline $2 \mathrm{H}-1,71$ & 6.71 & 8.13 & 55.71 & 2 & 5.630 & 0.755 & \\
\hline $2 \mathrm{H}-1,81$ & 6.81 & 8.23 & 48.79 & 1 & 3.887 & 0.748 & \\
\hline $2 \mathrm{H}-1,91$ & 6.91 & 8.33 & 51.48 & 1 & 3.505 & 0.798 & \\
\hline $2 \mathrm{H}-1,101$ & 7.01 & 8.43 & 32.42 & 2 & 1.898 & 0.769 & Contains some ash C \\
\hline $2 \mathrm{H}-1,111$ & 7.11 & 8.53 & 3.14 & 1 & & 0.933 & Ash C, not processed \\
\hline
\end{tabular}


Appendix B (continued).

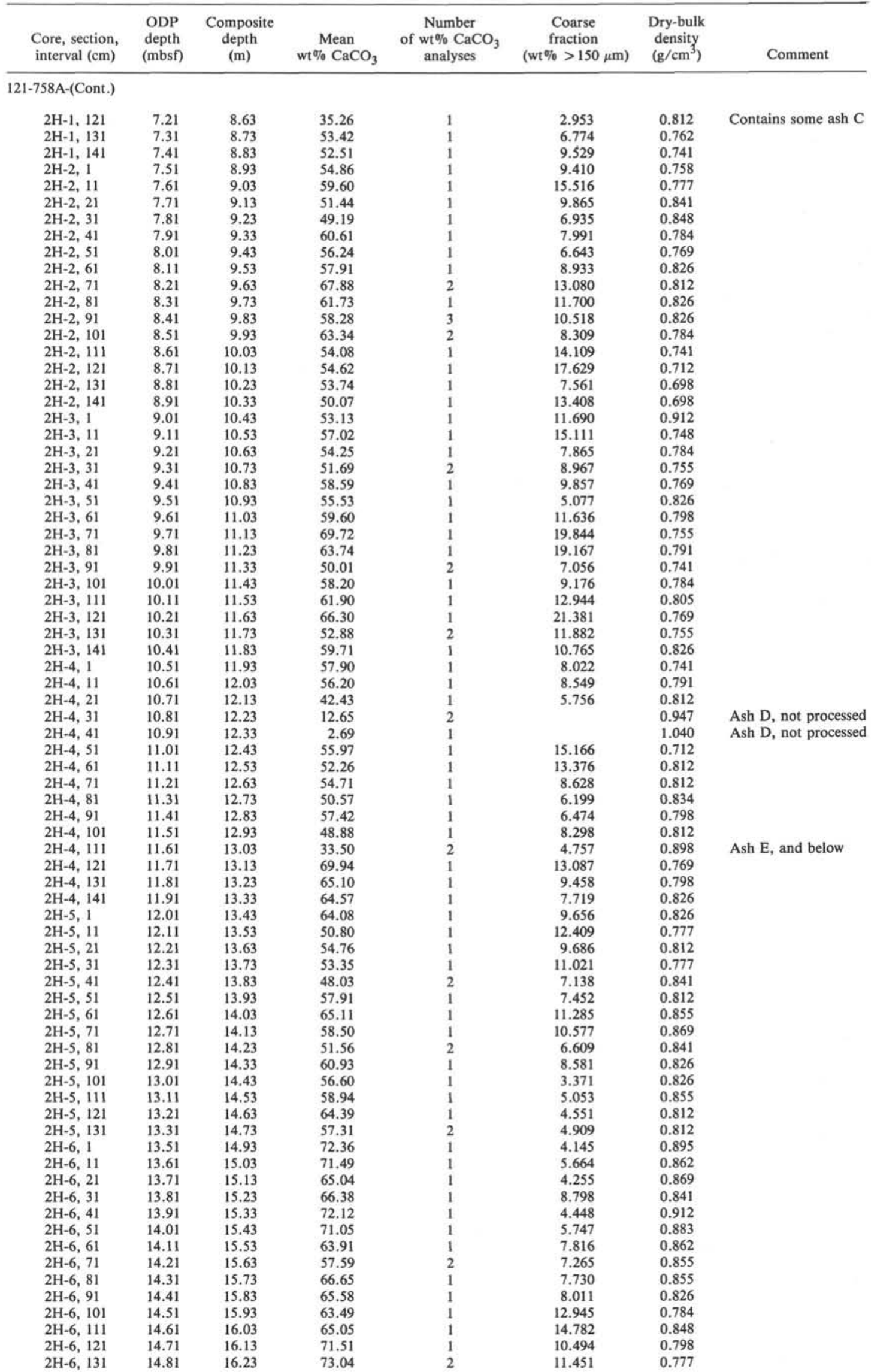


Appendix B (continued).

\begin{tabular}{|c|c|c|c|c|c|c|c|}
\hline $\begin{array}{l}\text { Core, section, } \\
\text { interval }(\mathrm{cm})\end{array}$ & $\begin{array}{l}\text { ODP } \\
\text { depth } \\
\text { (mbsf) }\end{array}$ & $\begin{array}{l}\text { Composite } \\
\text { depth } \\
\text { (m) }\end{array}$ & $\begin{array}{c}\text { Mean } \\
\text { wt } \% \mathrm{CaCO}_{3}\end{array}$ & $\begin{array}{c}\text { Number } \\
\text { of wt } \% \mathrm{CaCO}_{3} \\
\text { analyses }\end{array}$ & $\begin{array}{c}\text { Coarse } \\
\text { fraction } \\
(\mathrm{wt} \%>150 \mu \mathrm{m})\end{array}$ & $\begin{array}{l}\text { Dry-bulk } \\
\text { density } \\
\left(\mathrm{g} / \mathrm{cm}^{3}\right)\end{array}$ & Comment \\
\hline \multicolumn{8}{|l|}{ 121-758A-(Cont.) } \\
\hline $2 \mathrm{H}-6,141$ & 14.91 & 16.33 & 71.40 & 1 & 13.660 & 0.841 & \\
\hline $2 \mathrm{H}-7,1$ & 15.01 & 16.43 & 57.22 & 1 & 8.814 & 0.826 & \\
\hline $2 \mathrm{H}-7,11$ & 15.11 & 16.53 & 57.32 & 1 & 7.395 & 0.869 & \\
\hline $2 \mathrm{H}-7,21$ & 15.21 & 16.63 & 58.29 & $i$ & 7.102 & 0.798 & \\
\hline $2 \mathrm{H}-7,31$ & 15.31 & 16.73 & 57.56 & 1 & 8.536 & 0.755 & \\
\hline $2 \mathrm{H}-7,41$ & 15.41 & 16.83 & 64.97 & $i$ & 14.649 & 0.855 & \\
\hline $2 \mathrm{H}-7,51$ & 15.51 & 16.93 & 61.43 & 1 & 11.457 & 0.762 & \\
\hline $2 \mathrm{H}-7,61$ & 15.61 & 17.03 & 60.23 & 1 & 11.954 & 0.819 & \\
\hline $2 \mathrm{H}-7,71$ & 15.71 & 17.13 & 63.41 & 1 & 13.135 & 0.784 & \\
\hline $2 \mathrm{H}-\mathrm{CC}, 1$ & 15.78 & 17.20 & 65.96 & 1 & 13.015 & 0.812 & Tie point \\
\hline $2 \mathrm{H}-\mathrm{CC}, 11$ & 15.88 & 17.30 & 64.03 & 1 & 16.730 & 0.755 & Not in composite \\
\hline $3 \mathrm{H}-1,1$ & 15.61 & 17.52 & 59.84 & 1 & 10.873 & 0.801 & Not in composite \\
\hline $3 \mathrm{H}-1,11$ & 15.71 & 17.62 & 57.95 & $i$ & 8.407 & 0.791 & Not in composite \\
\hline $3 \mathrm{H}-1,21$ & 15.81 & 17.72 & 62.43 & 1 & 8.132 & 0.812 & Tie point \\
\hline $3 \mathrm{H}-1,31$ & 15.91 & 17.82 & 57.61 & 1 & 9.167 & 0.777 & \\
\hline $3 \mathrm{H}-1,41$ & 16.01 & 17.92 & 62.07 & 1 & 13.105 & 0.755 & \\
\hline $3 \mathrm{H}-1,51$ & 16.11 & 18.02 & 64.56 & 1 & 14.854 & 0.812 & \\
\hline $3 \mathrm{H}-1,61$ & 16.21 & 18.12 & 55.09 & 2 & 15.889 & 0.769 & \\
\hline $3 \mathrm{H}-1,71$ & 16.31 & 18.22 & 63.84 & 1 & 18.945 & 0.741 & \\
\hline $3 \mathrm{H}-1,81$ & 16.41 & 18.32 & 64.24 & 1 & 18.133 & 0.784 & \\
\hline $3 \mathrm{H}-1,91$ & 16.51 & 18.42 & 58.08 & 1 & 15.853 & 0.841 & \\
\hline $3 \mathrm{H}-1,101$ & 16.61 & 18.52 & 59.86 & 1 & 14.462 & 0.798 & \\
\hline $3 \mathrm{H}-1,111$ & 16.71 & 18.62 & 58.53 & 1 & 7.855 & 0.798 & \\
\hline $3 \mathrm{H}-1,121$ & 16.81 & 18.72 & 60.29 & 1 & 10.664 & 0.812 & \\
\hline $3 \mathrm{H}-1,131$ & 16.91 & 18.82 & 65.42 & 1 & 13.728 & 0.777 & \\
\hline $3 \mathrm{H}-1,141$ & 17.01 & 18.92 & 58.57 & 1 & 17.459 & 0.734 & \\
\hline $3 \mathrm{H}-2,1$ & 17.11 & 19.02 & 51.56 & 2 & 10.353 & 0.791 & \\
\hline $3 \mathrm{H}-2,11$ & 17.21 & 19.12 & 53.66 & 1 & 10.969 & 0.805 & \\
\hline $3 \mathrm{H}-2,21$ & 17.31 & 19.22 & 56.82 & 1 & 11.968 & 0.869 & \\
\hline $3 \mathrm{H}-2,31$ & 17.41 & 19.32 & 59.69 & 1 & 10.236 & 0.805 & \\
\hline $3 \mathrm{H}-2,41$ & 17.51 & 19.42 & 63.90 & 2 & 11.565 & 0.784 & \\
\hline $3 \mathrm{H}-2,51$ & 17.61 & 19.52 & 61.54 & 1 & 14.292 & 0.777 & \\
\hline $3 \mathrm{H}-2,61$ & 17.71 & 19.62 & 60.12 & 1 & 12.156 & 0.826 & \\
\hline $3 \mathrm{H}-2,71$ & 17.81 & 19.72 & 58.51 & $i$ & 16.052 & 0.784 & \\
\hline $3 \mathrm{H}-2,81$ & 17.91 & 19.82 & 49.49 & 2 & 11.486 & 0.848 & \\
\hline $3 \mathrm{H}-2,91$ & 18.01 & 19.92 & 61.82 & 1 & 7.191 & 0.812 & \\
\hline $3 \mathrm{H}-2,101$ & 18.11 & 20.02 & 61.92 & 1 & 11.004 & 0.812 & \\
\hline $3 \mathrm{H}-2,111$ & 18.21 & 20.12 & 65.22 & 1 & 14.720 & 0.755 & \\
\hline $3 \mathrm{H}-2,121$ & 18.31 & 20.22 & 64.48 & 1 & 15.649 & 0.798 & \\
\hline $3 \mathrm{H}-2,131$ & 18.41 & 20.32 & 62.36 & $i$ & 12.694 & 0.798 & \\
\hline $3 \mathrm{H}-2,141$ & 18.51 & 20.42 & 57.17 & 1 & 8.042 & 0.855 & \\
\hline $3 \mathrm{H}-3,1$ & 18.61 & 20.52 & 60.22 & 1 & 5.817 & 0.838 & \\
\hline $3 \mathrm{H}-3,11$ & 18.71 & 20.62 & 56.85 & 1 & 5.727 & 0.819 & \\
\hline $3 \mathrm{H}-3,21$ & 18.81 & 20.72 & 60.19 & 1 & 9.112 & 0.841 & \\
\hline $3 \mathrm{H}-3,31$ & 18.91 & 20.82 & 64.99 & 1 & 9.542 & 0.819 & \\
\hline $3 \mathrm{H}-3,41$ & 19.01 & 20.92 & 66.84 & 1 & 8.814 & 0.784 & \\
\hline $3 \mathrm{H}-3,51$ & 19.11 & 21.02 & 61.05 & 1 & 10.823 & 0.784 & \\
\hline $3 \mathrm{H}-3,61$ & 19.21 & 21.12 & 60.66 & 1 & 6.243 & 0.762 & \\
\hline $3 \mathrm{H}-3,71$ & 19.31 & 21.22 & 60.20 & 1 & 9.642 & 0.798 & \\
\hline $3 \mathrm{H}-3,81$ & 19.41 & 21.32 & 63.63 & 1 & 8.903 & 0.812 & \\
\hline $3 \mathrm{H}-3,91$ & 19.51 & 21.42 & 62.33 & 1 & 9.247 & 0.784 & \\
\hline $3 \mathrm{H}-3,101$ & 19.61 & 21.52 & 59.22 & 1 & 8.881 & 0.784 & \\
\hline $3 \mathrm{H}-3,111$ & 19.71 & 21.62 & 56.15 & 2 & 11.166 & 0.748 & \\
\hline $3 \mathrm{H}-3,12 \mathrm{I}$ & 19.81 & 21.72 & 31.20 & 2 & 5.636 & 0.784 & Ash $\mathrm{F}$, and below \\
\hline $3 \mathrm{H}-3,131$ & 19.91 & 21.82 & 56.60 & 1 & 10.162 & 0.841 & \\
\hline $3 \mathrm{H}-3,141$ & 20.01 & 21.92 & 61.11 & 1 & 8.168 & 0.784 & \\
\hline $3 \mathrm{H}-4,1$ & 20.11 & 22.02 & 58.22 & 1 & 9.052 & 0.855 & \\
\hline $3 \mathrm{H}-4,11$ & 20.21 & 22.12 & 61.41 & 1 & 9.866 & 0.862 & \\
\hline $3 \mathrm{H}-4,21$ & 20.31 & 22.22 & 67.38 & 2 & 10.318 & 0.798 & \\
\hline $3 \mathrm{H}-4,31$ & 20.41 & 22.32 & 58.06 & 1 & 11.628 & 0.805 & \\
\hline $3 \mathrm{H}-4,41$ & 20.51 & 22.42 & 55.77 & 1 & 14.556 & 0.755 & \\
\hline $3 \mathrm{H}-4,51$ & 20.61 & 22.52 & 61.14 & 1 & 9.516 & 0.883 & \\
\hline $3 \mathrm{H}-4,61$ & 20.71 & 22.62 & 57.12 & 1 & 9.412 & 0.812 & \\
\hline $3 \mathrm{H}-4,7 \mathrm{I}$ & 20.81 & 22.72 & 62.18 & 1 & 7.607 & 0.912 & \\
\hline $3 \mathrm{H}-4,81$ & 20.91 & 22.82 & 63.64 & 1 & 8.588 & 0.855 & \\
\hline $3 \mathrm{H}-4,91$ & 21.01 & 22.92 & 68.93 & 2 & 9.570 & 0.841 & \\
\hline $3 \mathrm{H}-4,101$ & 21.11 & 23.02 & 61.21 & 2 & 12.225 & 0.826 & \\
\hline $3 \mathrm{H}-4,111$ & 21.21 & 23.12 & 62.70 & 1 & 11.613 & 0.812 & \\
\hline $3 \mathrm{H}-4,121$ & 21.31 & 23.22 & 64.15 & 1 & 10.671 & 0.798 & \\
\hline $3 \mathrm{H}-4,131$ & 21.41 & 23.32 & 63.22 & 1 & 9.700 & 0.834 & \\
\hline $3 \mathrm{H}-4,14 \mathrm{I}$ & 21.51 & 23.42 & 59.85 & 1 & 11.969 & 0.826 & \\
\hline $3 \mathrm{H}-5,1$ & 21.61 & 23.52 & 66.09 & 1 & 16.097 & 0.849 & \\
\hline $3 \mathrm{H}-5,11$ & 21.71 & 23.62 & 65.05 & 1 & 14.716 & 0.805 & \\
\hline $3 \mathrm{H}-5,21$ & 21.81 & 23.72 & 58.88 & 1 & 16.032 & 0.812 & \\
\hline $3 \mathrm{H}-5,31$ & 21.91 & 23.82 & 60.36 & 1 & 11.579 & 0.841 & \\
\hline $3 \mathrm{H}-5,41$ & 22.01 & 23.92 & 61.87 & 1 & 10.369 & 0.869 & \\
\hline
\end{tabular}


Appendix B (continued).

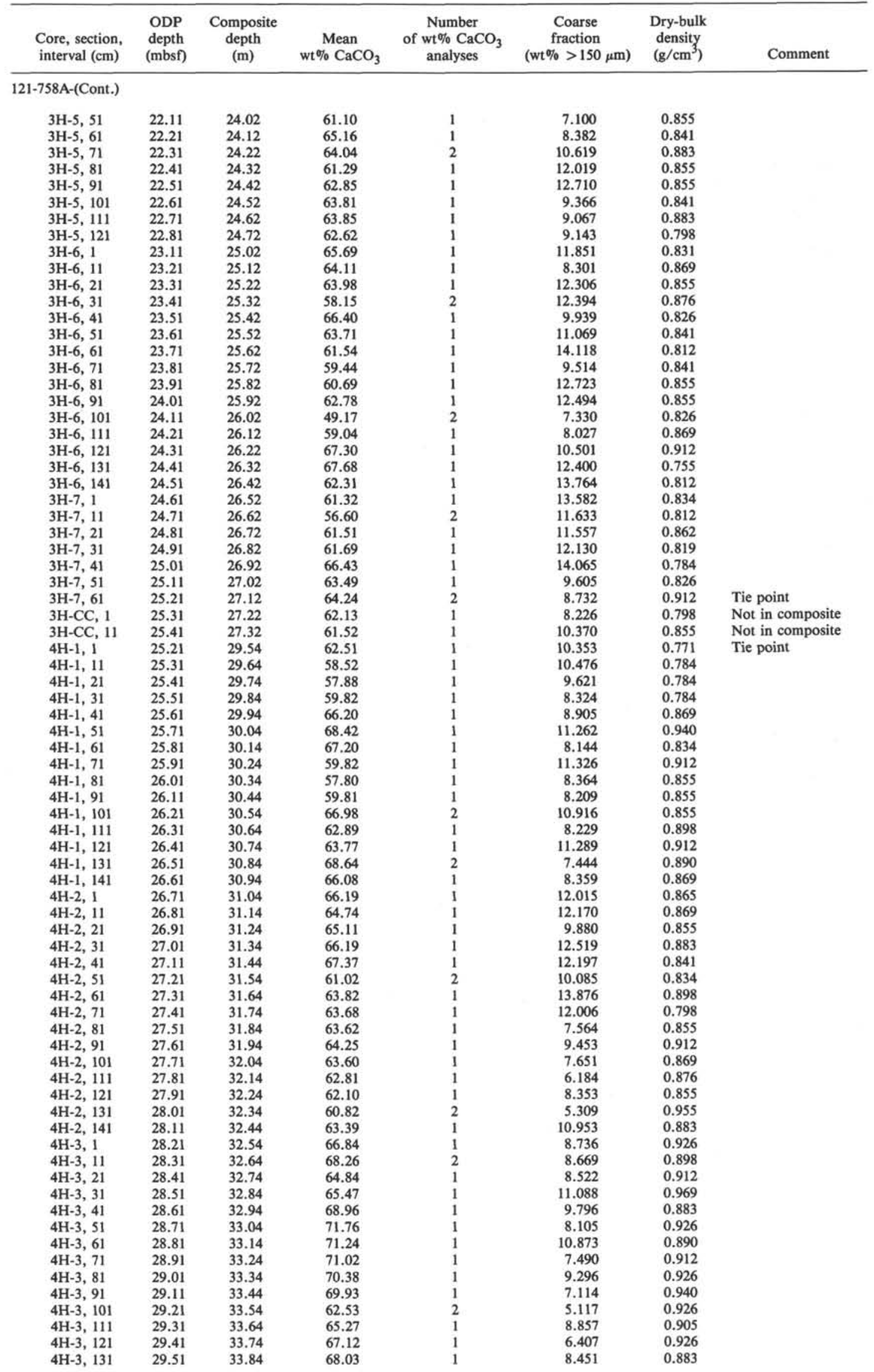


Appendix B (continued).

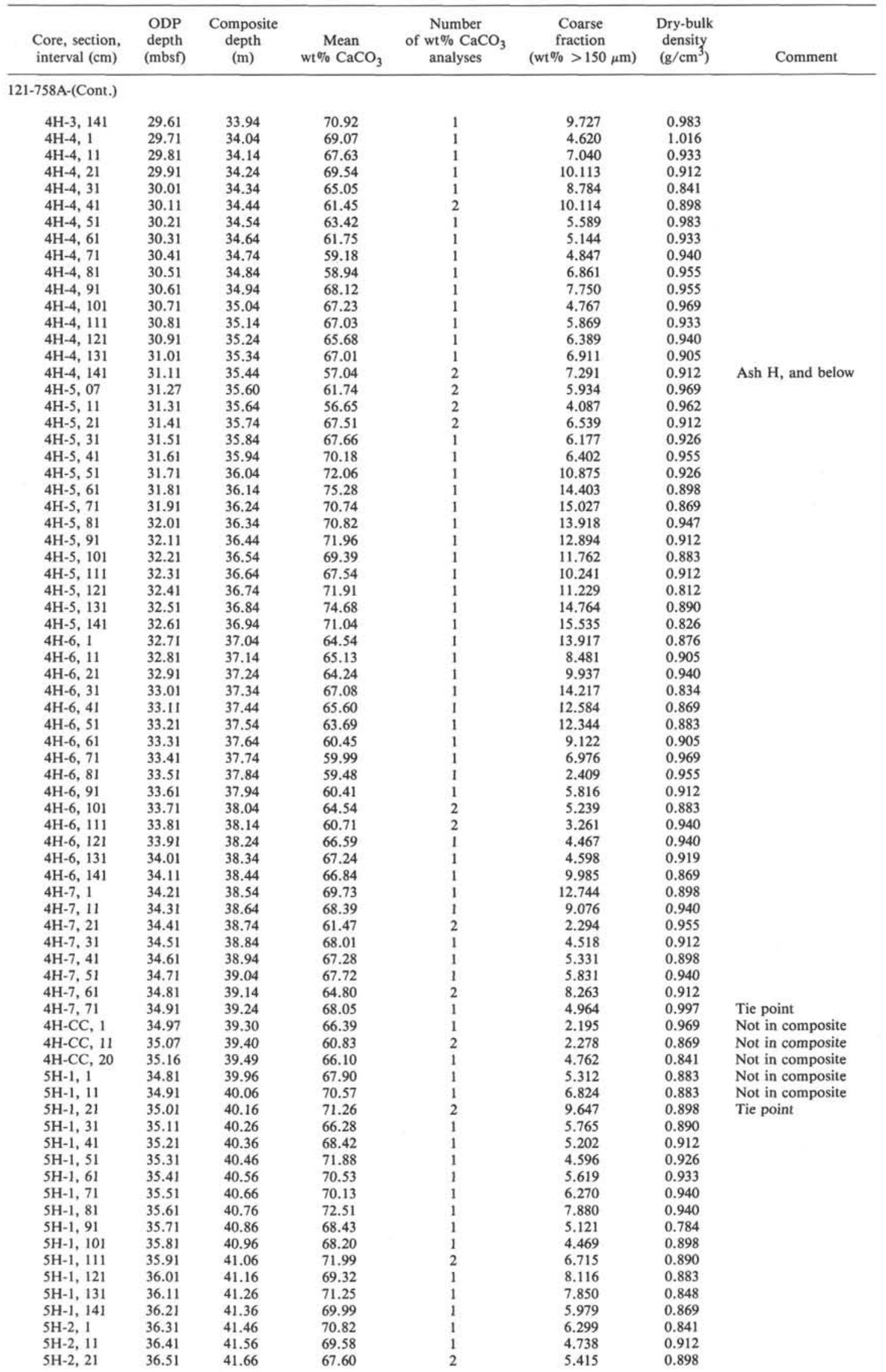


Appendix B (continued).

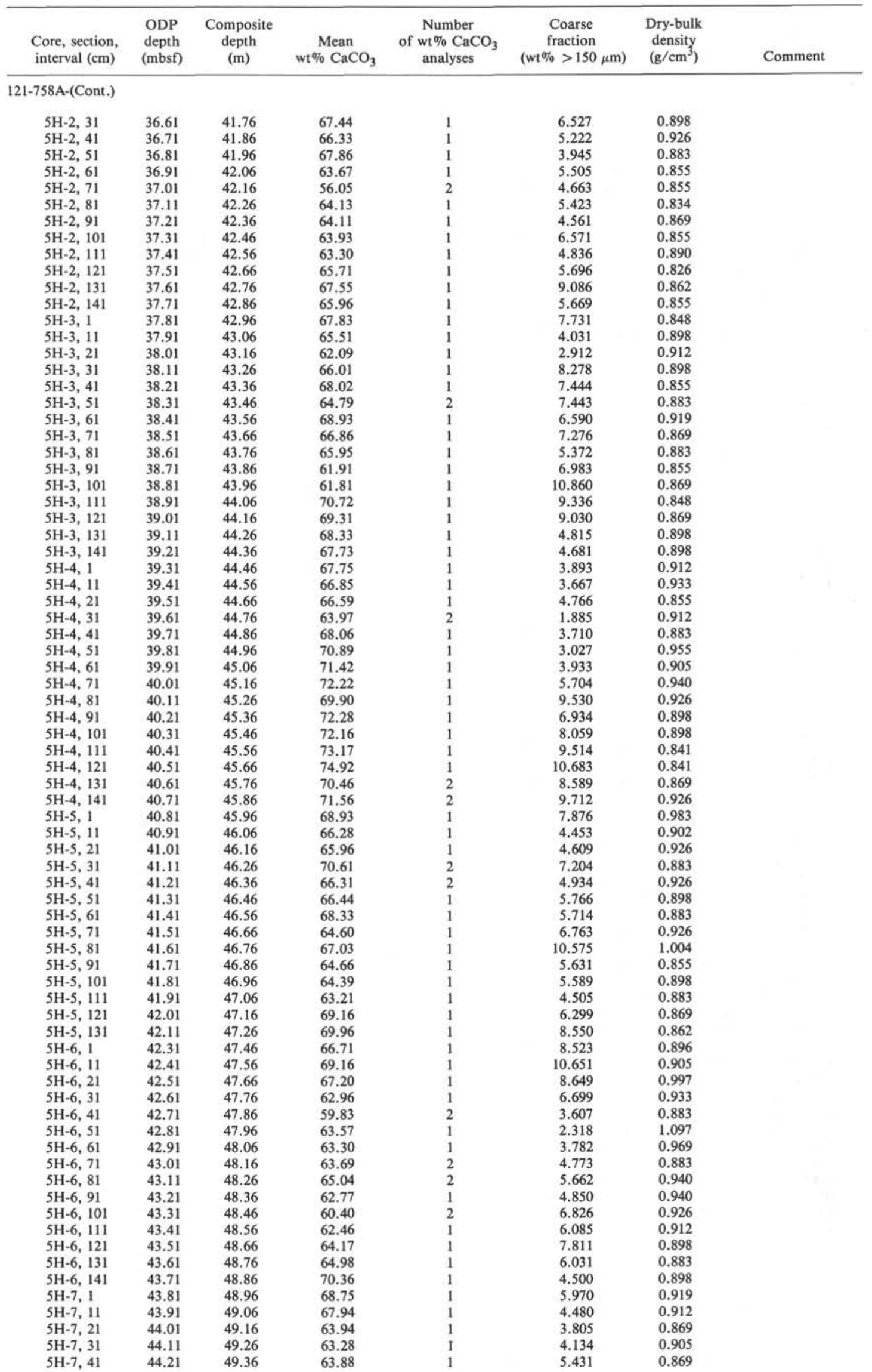


Appendix B (continued).

\begin{tabular}{|c|c|c|c|c|c|c|c|}
\hline $\begin{array}{l}\text { Core, section, } \\
\text { interval }(\mathrm{cm})\end{array}$ & $\begin{array}{l}\text { ODP } \\
\text { depth } \\
\text { (mbsf) }\end{array}$ & $\begin{array}{l}\text { Composite } \\
\text { depth } \\
\text { (m) }\end{array}$ & $\begin{array}{c}\text { Mean } \\
\text { wt } \% \mathrm{CaCO}_{3}\end{array}$ & $\begin{array}{c}\text { Number } \\
\text { of } \begin{array}{c}\text { wt } \% \mathrm{CaCO}_{3} \\
\text { analyses }\end{array}\end{array}$ & $\begin{array}{c}\text { Coarse } \\
\text { fraction } \\
(\mathrm{wt} \%>150 \mu \mathrm{m})\end{array}$ & $\begin{array}{l}\text { Dry-bulk } \\
\text { density } \\
\left(\mathrm{g} / \mathrm{cm}^{3}\right)\end{array}$ & Comment \\
\hline \multicolumn{8}{|l|}{ 121-758A-(Cont.) } \\
\hline $5 \mathrm{H}-7,51$ & 44.31 & 49.46 & 56.38 & 2 & 4.467 & 0.862 & Tie point \\
\hline $5 \mathrm{H}-7,61$ & 44.41 & 49.56 & 60.64 & 1 & 5.126 & 0.919 & Not in composite \\
\hline $6 \mathrm{H}-1,1$ & 44.41 & 51.78 & 66.63 & 2 & 3.740 & 0.883 & Not in composite \\
\hline $6 \mathrm{H}-1,11$ & 44.51 & 51.88 & 67.31 & 1 & 3.209 & 0.912 & Not in composite \\
\hline $6 \mathrm{H}-1,21$ & 44.61 & 51.98 & 65.93 & 1 & 3.679 & 0.869 & Not in composite \\
\hline $6 \mathrm{H}-1,31$ & 44.71 & 52.08 & 69.24 & 1 & 6.547 & 0.890 & Tie point \\
\hline $6 \mathrm{H}-1,41$ & 44.81 & 52.18 & 64.19 & 1 & 4.523 & 0.869 & \\
\hline $6 \mathrm{H}-1,51$ & 44.91 & 52.28 & 63.74 & 1 & 3.177 & 0.883 & \\
\hline $6 \mathrm{H}-1,61$ & 45.01 & 52.38 & 64.19 & 2 & 3.998 & 0.919 & \\
\hline $6 \mathrm{H}-1,71$ & 45.11 & 52.48 & 69.40 & 3 & 6.097 & 0.869 & \\
\hline $6 \mathrm{H}-1,81$ & 45.21 & 52.58 & 74.29 & 2 & 11.665 & 0.848 & \\
\hline $6 \mathrm{H}-1,91$ & 45.31 & 52.68 & 68.68 & 1 & 10.411 & 0.898 & \\
\hline $6 \mathrm{H}-1,101$ & 45.41 & 52.78 & 70.50 & 1 & 9.563 & 0.855 & \\
\hline $6 \mathrm{H}-1,111$ & 45.51 & 52.88 & 66.70 & 1 & 5.341 & 0.898 & \\
\hline $6 \mathrm{H}-1,121$ & 45.61 & 52.98 & 66.23 & 1 & 3.108 & 1.068 & \\
\hline $6 \mathrm{H}-1,131$ & 45.71 & 53.08 & 65.80 & 1 & 3.555 & 0.883 & \\
\hline $6 \mathrm{H}-1,141$ & 45.81 & 53.18 & 68.25 & 1 & 4.735 & 0.940 & \\
\hline $6 \mathrm{H}-2,1$ & 45.91 & 53.28 & 67.30 & 1 & 4.727 & 0.883 & \\
\hline $6 \mathrm{H}-2,11$ & 46.01 & 53.38 & 65.22 & 1 & 3.246 & 0.834 & \\
\hline $6 \mathrm{H}-2,21$ & 46.11 & 53.48 & 64.37 & 1 & 3.192 & 0.784 & \\
\hline $6 \mathrm{H}-2,31$ & 46.21 & 53.58 & 65.06 & 1 & 3.452 & 0.784 & \\
\hline $6 \mathrm{H}-2,41$ & 46.31 & 53.68 & 63.97 & 1 & 3.358 & 0.784 & \\
\hline $6 \mathrm{H}-2,51$ & 46.41 & 53.78 & 66.74 & 1 & 3.345 & 0.784 & \\
\hline $6 \mathrm{H}-2,61$ & 46.51 & 53.88 & 66.17 & 1 & 2.720 & 0.784 & \\
\hline $6 \mathrm{H}-2,71$ & 46.61 & 53.98 & 65.48 & 1 & 3.020 & 0.841 & \\
\hline $6 \mathrm{H}-2,81$ & 46.71 & 54.08 & 69.76 & 2 & 3.617 & 0.876 & \\
\hline $6 \mathrm{H}-2,91$ & 46.81 & 54.18 & 72.10 & 2 & 5.474 & 0.912 & \\
\hline $6 \mathrm{H}-2,101$ & 46.91 & 54.28 & 73.23 & 1 & 6.829 & 0.826 & \\
\hline $6 \mathrm{H}-2,111$ & 47.01 & 54.38 & 70.68 & 1 & 6.745 & 0.834 & \\
\hline $6 \mathrm{H}-2,121$ & 47.11 & 54.48 & 74.27 & 1 & 8.527 & 0.841 & \\
\hline $6 \mathrm{H}-2,131$ & 47.21 & 54.58 & 68.85 & 1 & 4.415 & 0.883 & \\
\hline $6 \mathrm{H}-2,141$ & 47.31 & 54.68 & 67.23 & 1 & 3.107 & 0.969 & \\
\hline $6 \mathrm{H}-3,1$ & 47.41 & 54.78 & 76.34 & 2 & 11.005 & 0.834 & \\
\hline $6 \mathrm{H}-3,11$ & 47.51 & 54.88 & 67.91 & 1 & 5.524 & 0.876 & \\
\hline $6 \mathrm{H}-3,21$ & 47.61 & 54.98 & 71.13 & 1 & 5.428 & 0.940 & \\
\hline $6 \mathrm{H}-3,31$ & 47.71 & 55.08 & 70.55 & 1 & 3.835 & 0.926 & \\
\hline $6 \mathrm{H}-3,41$ & 47.81 & 55.18 & 70.98 & 1 & 4.178 & 0.912 & \\
\hline $6 \mathrm{H}-3,51$ & 47.91 & 55.28 & 72.63 & 1 & 5.354 & 0.955 & \\
\hline $6 \mathrm{H}-3,61$ & 48.01 & 55.38 & 73.93 & $i$ & 5.530 & 0.862 & \\
\hline $6 \mathrm{H}-3,71$ & 48.11 & 55.48 & 72.83 & 1 & 6.892 & 0.883 & \\
\hline $6 \mathrm{H}-3,81$ & 48.21 & 55.58 & 75.88 & 1 & 7.318 & 0.905 & \\
\hline $6 \mathrm{H}-3,91$ & 48.31 & 55.68 & 74.07 & 1 & 5.061 & 0.926 & \\
\hline $6 \mathrm{H}-3,101$ & 48.41 & 55.78 & 71.96 & 1 & 5.047 & 0.898 & \\
\hline $6 \mathrm{H}-3,111$ & 48.51 & 55.88 & 72.18 & 1 & 8.290 & 0.912 & \\
\hline $6 \mathrm{H}-3,121$ & 48.61 & 55.98 & 71.68 & 1 & 7.264 & 0.940 & \\
\hline $6 \mathrm{H}-3,131$ & 48.71 & 56.08 & 72.45 & 1 & 5.076 & 0.912 & \\
\hline $6 \mathrm{H}-3,141$ & 48.81 & 56.18 & 74.14 & 1 & 5.838 & 0.912 & \\
\hline $6 \mathrm{H}-4,1$ & 48.91 & 56.28 & 67.60 & 1 & 4.139 & 0.869 & \\
\hline $6 \mathrm{H}-4,11$ & 49.01 & 56.38 & 69.34 & 1 & 4.705 & 0.933 & \\
\hline $6 \mathrm{H}-4,21$ & 49.11 & 56.48 & 68.69 & 1 & 3.812 & 0.940 & \\
\hline $6 \mathrm{H}-4,31$ & 49.21 & 56.58 & 66.87 & 1 & 5.250 & 0.947 & \\
\hline $6 \mathrm{H}-4,41$ & 49.31 & 56.68 & 72.30 & 1 & 6.686 & 0.926 & \\
\hline $6 \mathrm{H}-4,51$ & 49.41 & 56.78 & 73.36 & 1 & 10.886 & 1.012 & \\
\hline $6 \mathrm{H}-4,61$ & 49.51 & 56.88 & 73.49 & 1 & 5.690 & 0.962 & \\
\hline $6 \mathrm{H}-4,71$ & 49.61 & 56.98 & 69.43 & 1 & 7.249 & 0.940 & \\
\hline $6 \mathrm{H}-4,81$ & 49.71 & 57.08 & 69.08 & 1 & 6.343 & 0.940 & \\
\hline $6 \mathrm{H}-4,91$ & 49.81 & 57.18 & 67.22 & 1 & 4.578 & 1.026 & \\
\hline $6 \mathrm{H}-4,101$ & 49.91 & 57.28 & 71.79 & 1 & 7.131 & 0.855 & \\
\hline $6 \mathrm{H}-4,111$ & 50.01 & 57.38 & 75.31 & 1 & 9.163 & 0.983 & \\
\hline $6 \mathrm{H}-4,121$ & 50.11 & 57.48 & 75.56 & 1 & 11.355 & 0.898 & \\
\hline $6 \mathrm{H}-4,131$ & 50.21 & 57.58 & 73.78 & 1 & 11.620 & 0.883 & \\
\hline $6 \mathrm{H}-4,141$ & 50.31 & 57.68 & 72.23 & 1 & 8.390 & 0.912 & \\
\hline $6 \mathrm{H}-5,1$ & 50.41 & 57.78 & 70.10 & 1 & 7.391 & 1.004 & \\
\hline $6 \mathrm{H}-5,11$ & 50.51 & 57.88 & 67.66 & 1 & 5.866 & 0.983 & \\
\hline $6 \mathrm{H}-5,21$ & 50.61 & 57.98 & 70.70 & 1 & 7.322 & 0.841 & \\
\hline $6 \mathrm{H}-5,31$ & 50.71 & 58.08 & 66.58 & 1 & 6.961 & 0.890 & \\
\hline $6 \mathrm{H}-5,41$ & 50.81 & 58.18 & 67.10 & 1 & 5.730 & 0.855 & \\
\hline $6 \mathrm{H}-5,51$ & 50.91 & 58.28 & 44.09 & 2 & 5.304 & 0.969 & Ash blebs \\
\hline $6 \mathrm{H}-5,61$ & 51.01 & 58.38 & 67.55 & 1 & 8.307 & 0.905 & \\
\hline $6 \mathrm{H}-5,71$ & 51.11 & 58.48 & 72.83 & 1 & 6.929 & 0.926 & \\
\hline $6 \mathrm{H}-5,81$ & 51.21 & 58.58 & 70.21 & 1 & 6.639 & 0.919 & \\
\hline $6 \mathrm{H}-5,91$ & 51.31 & 58.68 & 70.65 & $i$ & 8.396 & 0.869 & \\
\hline $6 \mathrm{H}-5,101$ & 51.41 & 58.78 & 71.80 & $i$ & 6.339 & 0.898 & \\
\hline $6 \mathrm{H}-5,111$ & 51.51 & 58.88 & 70.51 & 1 & 5.633 & 0.933 & \\
\hline $6 \mathrm{H}-5,121$ & 51.61 & 58.98 & 69.46 & 1 & 4.857 & 0.940 & \\
\hline $6 \mathrm{H}-6,1$ & 51.91 & 59.28 & 68.13 & 1 & 7.236 & 0.929 & \\
\hline
\end{tabular}


Appendix B (continued).

\begin{tabular}{|c|c|c|c|c|c|c|c|}
\hline $\begin{array}{l}\text { Core, section, } \\
\text { interval }(\mathrm{cm})\end{array}$ & $\begin{array}{l}\text { ODP } \\
\text { depth } \\
\text { (mbsf) }\end{array}$ & $\begin{array}{l}\text { Composite } \\
\text { depth } \\
\text { (m) }\end{array}$ & $\begin{array}{c}\text { Mean } \\
\text { wt } \% \mathrm{CaCO}_{3}\end{array}$ & $\begin{array}{c}\text { Number } \\
\text { of wt } \% \mathrm{CaCO}_{3} \\
\text { analyses }\end{array}$ & $\begin{array}{c}\text { Coarse } \\
\text { fraction } \\
(w t \%>150 \mu \mathrm{m})\end{array}$ & $\begin{array}{c}\text { Dry-bulk } \\
\text { density } \\
\left(\mathrm{g} / \mathrm{cm}^{3}\right)\end{array}$ & Comment \\
\hline \multicolumn{8}{|l|}{ 121-758A-(Cont.) } \\
\hline $6 \mathrm{H}-6,11$ & 52.01 & 59.38 & 60.26 & 1 & 4.968 & 0.969 & \\
\hline $6 \mathrm{H}-6,21$ & 52.11 & 59.48 & 61.28 & 1 & 3.252 & 0.926 & \\
\hline $6 \mathrm{H}-6,31$ & 52.21 & 59.58 & 56.66 & 1 & 4.418 & 0.912 & \\
\hline $6 \mathrm{H}-6,41$ & 52.31 & 59.68 & 57.25 & 1 & 3.851 & 0.926 & \\
\hline $6 \mathrm{H}-6,51$ & 52.41 & 59.78 & 72.23 & 1 & 6.891 & 0.940 & \\
\hline $6 \mathrm{H}-6,61$ & 52.51 & 59.88 & 71.35 & 1 & 7.765 & 0.919 & \\
\hline $6 \mathrm{H}-6,71$ & 52.61 & 59.98 & 68.13 & 1 & 4.948 & 0.955 & \\
\hline $6 \mathrm{H}-6,81$ & 52.71 & 60.08 & 68.62 & 1 & 5.100 & 0.883 & \\
\hline $6 \mathrm{H}-6,91$ & 52.81 & 60.18 & 68.90 & 1 & 4.742 & 0.912 & \\
\hline $6 \mathrm{H}-6,101$ & 52.91 & 60.28 & 67.26 & 1 & 5.010 & 0.826 & \\
\hline $6 \mathrm{H}-6,111$ & 53.01 & 60.38 & 58.28 & 2 & 3.477 & 0.890 & \\
\hline $6 \mathrm{H}-6,121$ & 53.11 & 60.48 & 63.56 & 1 & 4.600 & 0.997 & \\
\hline $6 \mathrm{H}-6,131$ & 53.21 & 60.58 & 65.87 & 1 & 5.211 & 0.926 & \\
\hline $6 \mathrm{H}-6,141$ & 53.31 & 60.68 & 55.85 & 2 & 4.934 & 0.969 & \\
\hline $6 \mathrm{H}-7,1$ & 53.41 & 60.78 & 69.54 & 1 & 5.710 & 0.969 & \\
\hline $6 \mathrm{H}-7,11$ & 53.51 & 60.88 & 72.81 & $i$ & 6.613 & 0.826 & \\
\hline $6 \mathrm{H}-7,21$ & 53.61 & 60.98 & 71.48 & 1 & 6.551 & 0.905 & \\
\hline $6 \mathrm{H}-7,31$ & 53.71 & 61.08 & 73.40 & 1 & 7.072 & 0.912 & \\
\hline $6 \mathrm{H}-7,41$ & 53.81 & 61.18 & 71.60 & 1 & 6.315 & 0.947 & \\
\hline $6 \mathrm{H}-7,51$ & 53.91 & 61.28 & 70.96 & 1 & 5.706 & 0.926 & \\
\hline $6 \mathrm{H}-7,61$ & 54.01 & 61.38 & 71.57 & 1 & 5.735 & 0.905 & \\
\hline $6 \mathrm{H}-7,71$ & 54.11 & 61.48 & 25.13 & 2 & 2.365 & 0.940 & Tie point \\
\hline $6 \mathrm{H}-\mathrm{CC}, 1$ & 54.13 & 61.50 & 67.37 & 1 & 5.844 & 0.926 & Not in composite \\
\hline $6 \mathrm{H}-\mathrm{CC}, 11$ & 54.23 & 61.60 & 66.07 & 1 & 6.650 & 0.912 & Not in composite \\
\hline $6 \mathrm{H}-\mathrm{CC}, 21$ & 54.33 & 61.70 & 69.08 & $i$ & 8.585 & 0.940 & Not in composite \\
\hline $7 \mathrm{H}-1,1$ & 54.01 & 63.20 & 69.11 & 1 & 5.378 & 0.829 & Tie point \\
\hline $7 \mathrm{H}-1,11$ & 54.11 & 63.30 & 52.69 & 2 & 3.140 & 0.829 & \\
\hline $7 \mathrm{H}-1,21$ & 54.21 & 63.40 & 58.65 & 2 & 2.436 & 0.855 & \\
\hline $7 \mathrm{H}-1,31$ & 54.31 & 63.50 & 65.40 & 1 & 3.228 & 0.826 & \\
\hline $7 \mathrm{H}-1,41$ & 54.41 & 63.60 & 69.83 & 1 & 4.670 & 0.940 & \\
\hline $7 \mathrm{H}-1,51$ & 54.51 & 63.70 & 66.37 & 1 & 3.205 & 0.898 & \\
\hline $7 \mathrm{H}-1,61$ & 54.61 & 63.80 & 57.42 & 2 & 2.363 & 0.883 & \\
\hline $7 \mathrm{H}-1,71$ & 54.71 & 63.90 & 60.64 & 1 & 2.835 & 0.926 & \\
\hline $7 \mathrm{H}-1,81$ & 54.81 & 64.00 & 69.60 & 1 & 3.222 & 0.876 & \\
\hline $7 \mathrm{H}-1,91$ & 54.91 & 64.10 & 71.70 & 1 & 4.137 & 0.926 & \\
\hline $7 \mathrm{H}-1,101$ & 55.01 & 64.20 & 72.09 & 1 & 5.140 & 0.926 & \\
\hline $7 \mathrm{H}-1,111$ & 55.11 & 64.30 & 64.79 & 1 & 2.562 & 1.040 & \\
\hline $7 \mathrm{H}-1,121$ & 55.21 & 64.40 & 61.63 & 1 & 2.573 & 1.111 & \\
\hline $7 \mathrm{H}-1,131$ & 55.31 & 64.50 & 62.06 & 1 & 2.081 & 0.940 & \\
\hline $7 \mathrm{H}-1,141$ & 55.41 & 64.60 & 71.98 & 1 & 2.989 & 0.912 & \\
\hline $7 \mathrm{H}-2,1$ & 55.51 & 64.70 & 74.16 & 1 & 5.497 & 0.937 & \\
\hline $7 \mathrm{H}-2,11$ & 55.61 & 64.80 & 74.24 & 1 & 4.878 & 0.883 & \\
\hline $7 \mathrm{H}-2,21$ & 55.71 & 64.90 & 72.15 & 1 & 3.770 & 0.869 & \\
\hline $7 \mathrm{H}-2,31$ & 55.81 & 65.00 & 69.64 & 1 & 2.296 & 0.933 & \\
\hline $7 \mathrm{H}-2,41$ & 55.91 & 65.10 & 69.89 & 1 & 2.968 & 0.898 & \\
\hline $7 \mathrm{H}-2,51$ & 56.01 & 65.20 & 72.35 & 1 & 4.521 & 0.883 & \\
\hline $7 \mathrm{H}-2,61$ & 56.11 & 65.30 & 72.98 & 1 & 5.144 & 0.933 & \\
\hline $7 \mathrm{H}-2,71$ & 56.21 & 65.40 & 73.27 & $i$ & 4.012 & 0.955 & \\
\hline $7 \mathrm{H}-2,81$ & 56.31 & 65.50 & 72.86 & 1 & 5.042 & 0.926 & \\
\hline $7 \mathrm{H}-2,91$ & 56.41 & 65.60 & 71.05 & 1 & 3.650 & 0.912 & \\
\hline $7 \mathrm{H}-2,101$ & 56.51 & 65.70 & 68.20 & 1 & 5.196 & 0.883 & \\
\hline $7 \mathrm{H}-2,111$ & 56.61 & 65.80 & 69.60 & 1 & 4.559 & 0.926 & \\
\hline $7 \mathrm{H}-2,121$ & 56.71 & 65.90 & 6.22 & $i$ & & 1.040 & Ash I, not processed \\
\hline $7 \mathrm{H}-2,131$ & 56.81 & 66.00 & 73.65 & 1 & 3.507 & 0.862 & \\
\hline $7 \mathrm{H}-2,141$ & 56.91 & 66.10 & 75.92 & 1 & 4.929 & 0.926 & \\
\hline $7 \mathrm{H}-3,1$ & 57.01 & 66.20 & 75.79 & 1 & 4.238 & 0.890 & \\
\hline $7 \mathrm{H}-3,11$ & 57.11 & 66.30 & 75.74 & 1 & 5.674 & 0.841 & \\
\hline $7 \mathrm{H}-3,21$ & 57.21 & 66.40 & 74.35 & 1 & 6.073 & 0.926 & \\
\hline $7 \mathrm{H}-3,31$ & 57.31 & 66.50 & 69.39 & 1 & 6.457 & 0.855 & \\
\hline $7 \mathrm{H}-3,41$ & 57.41 & 66.60 & 47.57 & 2 & 6.662 & 0.812 & \\
\hline $7 \mathrm{H}-3,51$ & 57.51 & 66.70 & 75.65 & 1 & 9.181 & 0.912 & \\
\hline $7 \mathrm{H}-3,61$ & 57.61 & 66.80 & 72.38 & 1 & 4.137 & 0.926 & \\
\hline $7 \mathrm{H}-3,71$ & 57.71 & 66.90 & 61.82 & 2 & 2.264 & 0.883 & \\
\hline $7 \mathrm{H}-3,81$ & 57.81 & 67.00 & 73.25 & 1 & 4.174 & 0.855 & \\
\hline $7 \mathrm{H}-3,91$ & 57.91 & 67.10 & 76.11 & 1 & 6.358 & 0.912 & \\
\hline $7 \mathrm{H}-3,101$ & 58.01 & 67.20 & 76.53 & 1 & 7.307 & 0.883 & \\
\hline $7 \mathrm{H}-3,111$ & 58.11 & 67.30 & 72.00 & 1 & 7.559 & 0.890 & \\
\hline $7 \mathrm{H}-3,121$ & 58.21 & 67.40 & 71.76 & 1 & 6.846 & 0.869 & \\
\hline $7 \mathrm{H}-3,131$ & 58.31 & 67.50 & 73.85 & 1 & 3.483 & 0.969 & \\
\hline $7 \mathrm{H}-3,141$ & 58.41 & 67.60 & 69.36 & 1 & 4.288 & 0.962 & \\
\hline $7 \mathrm{H}-4,1$ & 58.51 & 67.70 & 72.98 & 1 & 4.592 & 0.890 & \\
\hline $7 \mathrm{H}-4,11$ & 58.61 & 67.80 & 78.75 & 1 & 6.374 & 0.862 & \\
\hline $7 \mathrm{H}-4,21$ & 58.71 & 67.90 & 74.27 & 1 & 7.475 & 0.898 & \\
\hline $7 \mathrm{H}-4,31$ & 58.81 & 68.00 & 64.11 & $i$ & 5.427 & 0.962 & \\
\hline $7 \mathrm{H}-4,41$ & 58.91 & 68.10 & 50.11 & 2 & 4.974 & 0.997 & Ash \\
\hline $7 \mathrm{H}-4,51$ & 59.01 & 68.20 & 79.30 & 1 & 4.665 & 0.940 & \\
\hline
\end{tabular}


Appendix B (continued).

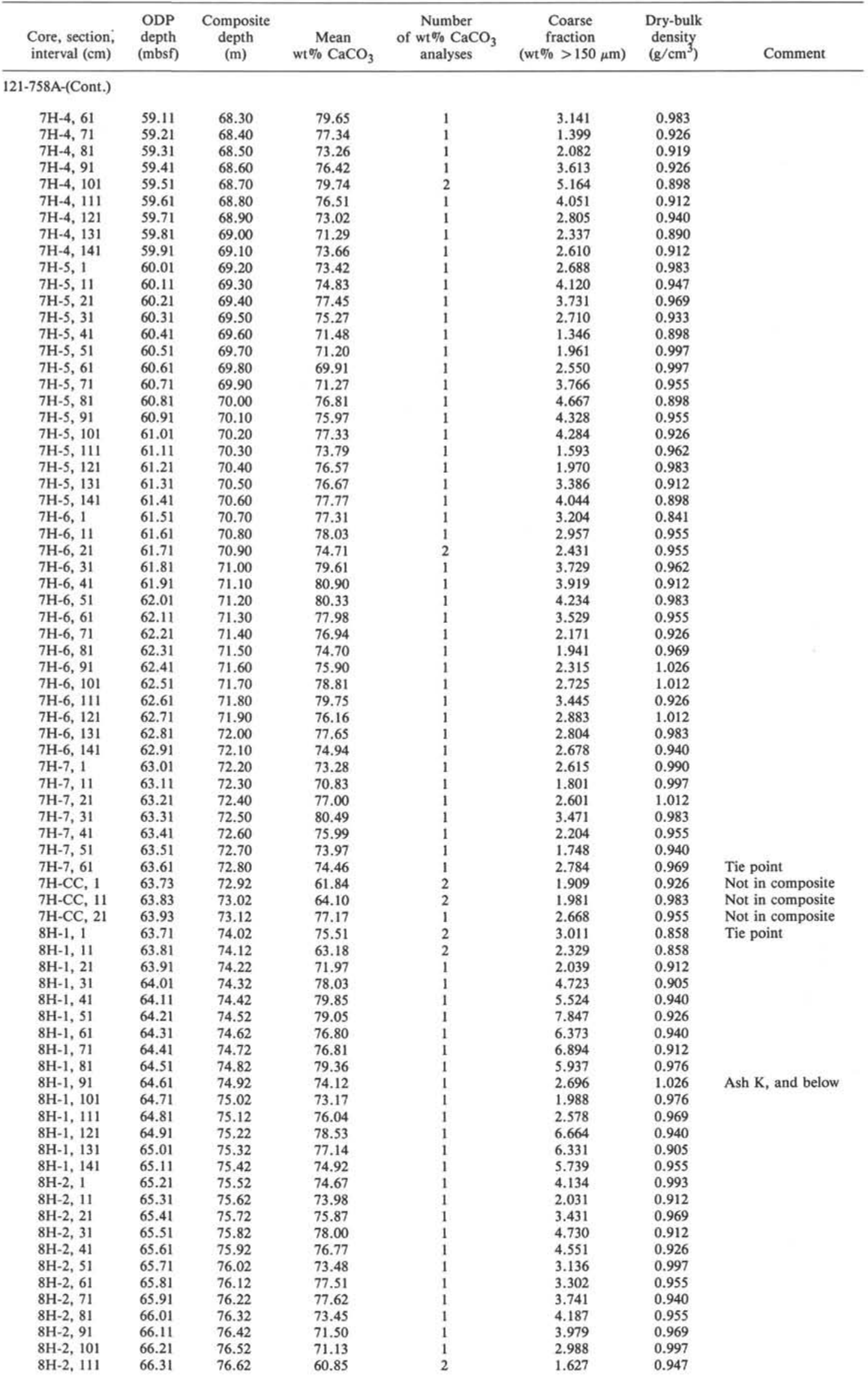


Appendix B (continued).

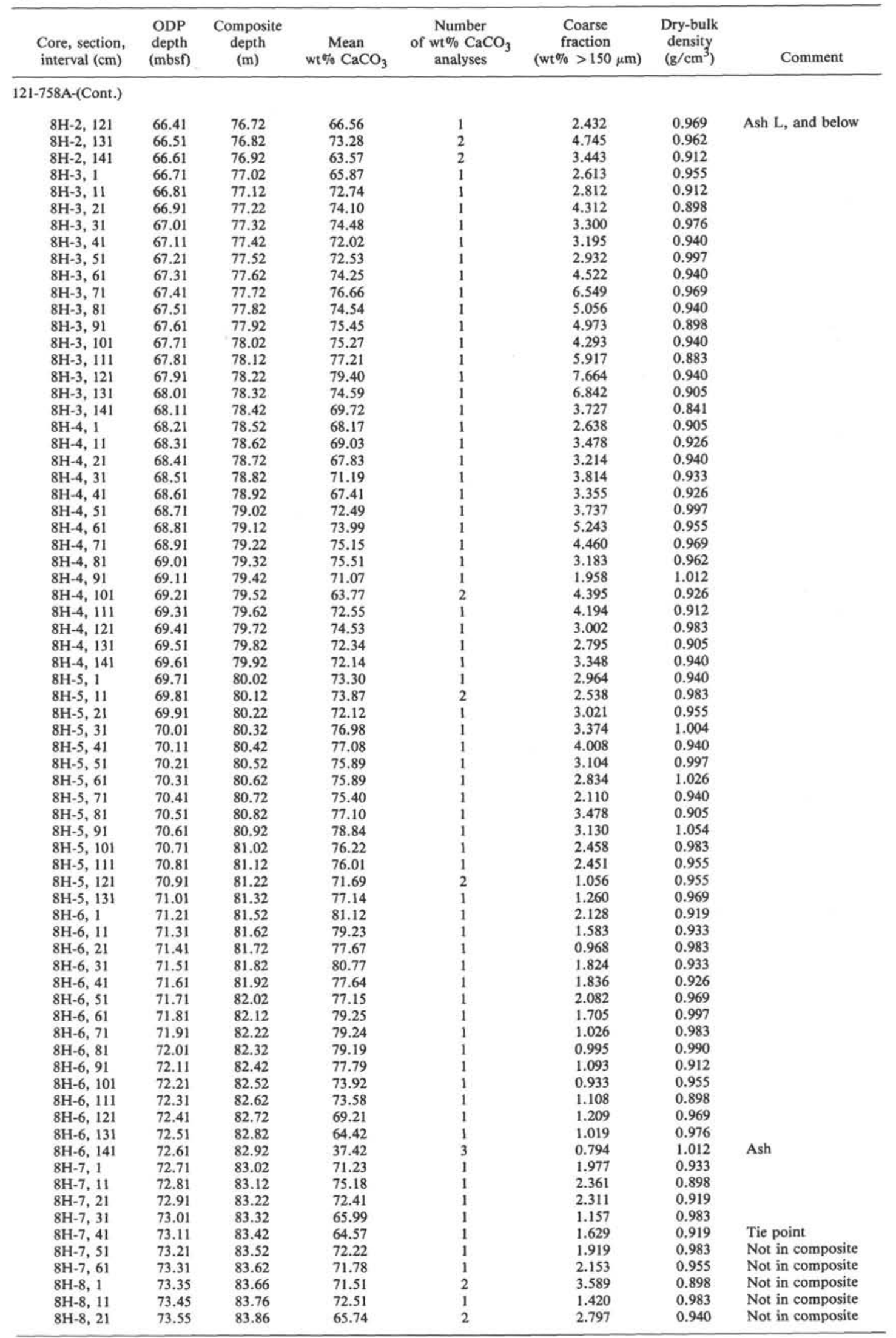


APPENDIX C

Wt\% $\mathrm{CaCO}_{3}$, Wt\% Coarse Fraction, and Dry-Bulk Density Data From Hole 758B

\begin{tabular}{|c|c|c|c|c|c|c|c|}
\hline $\begin{array}{l}\text { Core, section, } \\
\text { interval }(\mathrm{cm})\end{array}$ & $\begin{array}{l}\text { ODP } \\
\text { depth } \\
\text { (mbsf) }\end{array}$ & $\begin{array}{l}\text { Composite } \\
\text { depth } \\
\text { (m) }\end{array}$ & $\underset{\text { wt } \% \mathrm{CaCO}_{3}}{\text { Mean }}$ & $\begin{array}{c}\text { Number } \\
\text { of wt } \% \mathrm{CaCO}_{3} \\
\text { analyses }\end{array}$ & $\begin{array}{c}\text { Coarse } \\
\text { fraction } \\
(\mathrm{wt} \%>150 \mu \mathrm{m})\end{array}$ & $\begin{array}{l}\text { Dry-bulk } \\
\text { density } \\
\left(\mathrm{g} / \mathrm{cm}^{3}\right)\end{array}$ & Comment \\
\hline \multicolumn{8}{|l|}{$121-758 \mathrm{~B}-$} \\
\hline $1 \mathrm{H}-3,61$ & 3.61 & 5.12 & 59.98 & 2 & 14.18 & 0.705 & Not in composite \\
\hline $1 \mathrm{H}-3,71$ & 3.71 & 5.22 & 51.70 & 1 & 9.19 & 0.727 & Not in composite \\
\hline $1 \mathrm{H}-3,81$ & 3.81 & 5.32 & 49.10 & 2 & 6.09 & 0.741 & Tie point \\
\hline $1 \mathrm{H}-3,91$ & 3.91 & 5.42 & 53.90 & 2 & 4.70 & 0.841 & \\
\hline IH-3, 101 & 4.01 & 5.52 & 61.74 & 2 & 8.73 & 0.769 & \\
\hline $1 \mathrm{H}-3,111$ & 4.11 & 5.62 & 59.60 & 2 & 5.07 & 0.712 & \\
\hline $1 \mathrm{H}-3,121$ & 4.21 & 5.72 & 66.99 & 1 & 9.09 & 0.812 & \\
\hline $1 \mathrm{H}-3,131$ & 4.31 & 5.82 & 73.88 & 2 & 5.76 & 0.819 & \\
\hline $1 \mathrm{H}-3,141$ & 4.41 & 5.92 & 68.69 & 1 & 6.66 & 0.855 & \\
\hline $1 \mathrm{H}-4,1$ & 4.51 & 6.02 & 60.63 & 2 & 4.41 & 0.791 & \\
\hline $1 \mathrm{H}-4,11$ & 4.61 & 6.12 & 62.54 & 1 & 5.48 & 0.812 & \\
\hline $1 \mathrm{H}-4,21$ & 4.71 & 6.22 & 71.18 & 2 & 4.90 & 0.841 & \\
\hline $1 \mathrm{H}-4,31$ & 4.81 & 6.32 & 65.70 & 1 & 8.33 & 0.762 & \\
\hline $1 \mathrm{H}-4,41$ & 4.91 & 6.42 & 55.04 & 1 & 11.35 & 0.755 & \\
\hline $1 \mathrm{H}-4,51$ & 5.01 & 6.52 & 56.28 & 1 & 13.08 & 0.755 & \\
\hline $1 \mathrm{H}-4,61$ & 5.11 & 6.62 & 57.75 & 1 & 11.24 & 0.798 & \\
\hline $1 \mathrm{H}-4,71$ & 5.21 & 6.72 & 57.88 & 1 & 10.22 & 0.812 & \\
\hline $1 \mathrm{H}-4,81$ & 5.31 & 6.82 & 53.87 & 2 & 7.49 & 0.741 & \\
\hline $1 \mathrm{H}-4,91$ & 5.41 & 6.92 & 55.63 & 1 & 7.00 & 0.784 & \\
\hline $1 \mathrm{H}-4,101$ & 5.51 & 7.02 & 57.83 & 1 & 6.09 & 0.784 & \\
\hline $1 \mathrm{H}-4,111$ & 5.61 & 7.12 & 57.61 & 1 & 6.36 & 0.748 & \\
\hline $1 \mathrm{H}-4,121$ & 5.71 & 7.22 & 56.79 & 1 & 6.35 & 0.798 & \\
\hline $1 \mathrm{H}-4,131$ & 5.81 & 7.32 & 52.04 & 1 & 2.49 & 0.805 & \\
\hline $1 \mathrm{H}-4,141$ & 5.91 & 7.42 & 53.18 & 1 & 2.82 & 0.841 & Tie point \\
\hline $1 \mathrm{H}-5,1$ & 6.01 & 7.52 & 55.82 & 1 & 10.87 & 0.758 & Not in composite \\
\hline $1 \mathrm{H}-5,11$ & 6.11 & 7.62 & 50.21 & 2 & 7.41 & 0.698 & Not in composite \\
\hline $1 \mathrm{H}-5,21$ & 6.21 & 7.72 & 51.78 & 1 & 8.47 & 0.769 & Not in composite \\
\hline $1 \mathrm{H}-5,31$ & 6.31 & 7.82 & 54.67 & 1 & 9.65 & 0.784 & Not in composite \\
\hline $1 \mathrm{H}-5,41$ & 6.41 & 7.92 & 53.42 & 1 & 7.65 & 0.784 & Not in composite \\
\hline $1 \mathrm{H}-5,51$ & 6.51 & 8.02 & 56.09 & 1 & 8.03 & 0.769 & Not in composite \\
\hline $1 \mathrm{H}-5,61$ & 6.61 & 8.12 & 54.46 & 1 & 5.87 & 0.784 & Not in composite \\
\hline $2 \mathrm{H}-5,1$ & 15.51 & 17.01 & 53.00 & 2 & 10.20 & 0.762 & Not in composite \\
\hline $2 \mathrm{H}-5,11$ & 15.61 & 17.11 & 61.11 & 2 & 14.08 & 0.819 & Not in composite \\
\hline $2 \mathrm{H}-5,21$ & 15.71 & 17.21 & 63.96 & 1 & 13.63 & 0.784 & Tie point \\
\hline $2 \mathrm{H}-5,31$ & 15.81 & 17.31 & 67.40 & 1 & 18.57 & 0.805 & \\
\hline $2 \mathrm{H}-5,41$ & 15.91 & 17.41 & 54.76 & 1 & 13.03 & 0.798 & \\
\hline $2 \mathrm{H}-5,51$ & 16.01 & 17.51 & 59.97 & 2 & 12.42 & 0.784 & \\
\hline $2 \mathrm{H}-5,61$ & 16.11 & 17.61 & 57.46 & 1 & 9.49 & 0.841 & \\
\hline $2 \mathrm{H}-5,71$ & 16.21 & 17.71 & 65.09 & 1 & 9.45 & 0.798 & Tie point \\
\hline $2 \mathrm{H}-5,81$ & 16.31 & 17.81 & 61.51 & 2 & 12.01 & 0.769 & Not in composite \\
\hline $3 \mathrm{H}-3,111$ & 23.01 & 26.83 & 63.39 & 1 & 12.13 & 0.855 & Not in composite \\
\hline $3 \mathrm{H}-3,121$ & 23.11 & 26.93 & 63.78 & 1 & 13.68 & 0.826 & Not in composite \\
\hline $3 \mathrm{H}-3,13 \mathrm{I}$ & 23.21 & 27.03 & 65.99 & 1 & 14.15 & 0.812 & Not in composite \\
\hline $3 \mathrm{H}-3,141$ & 23.31 & 27.13 & 64.63 & 1 & 9.11 & 0.841 & Tie point \\
\hline $3 \mathrm{H}-4,1$ & 23.41 & 27.23 & 61.54 & 1 & 10.60 & 0.912 & \\
\hline $3 \mathrm{H}-4,11$ & 23.51 & 27.33 & 60.24 & 1 & 13.16 & 0.819 & \\
\hline $3 \mathrm{H}-4,21$ & 23.61 & 27.43 & 59.22 & 1 & 8.06 & 0.855 & \\
\hline $3 \mathrm{H}-4,31$ & 23.71 & 27.53 & 60.81 & 1 & 7.84 & 0.784 & \\
\hline $3 \mathrm{H}-4,41$ & 23.81 & 27.63 & 53.93 & 1 & 6.12 & 0.826 & \\
\hline $3 \mathrm{H}-4,51$ & 23.91 & 27.73 & 55.08 & 1 & 8.49 & 0.812 & Ash G, and below \\
\hline $3 \mathrm{H}-4,73$ & 24.13 & 27.95 & 66.21 & 1 & 8.75 & 0.841 & \\
\hline $3 \mathrm{H}-4,81$ & 24.21 & 28.03 & 62.79 & 1 & 10.73 & 0.883 & \\
\hline $3 \mathrm{H}-4,91$ & 24.31 & 28.13 & 62.44 & 1 & 10.44 & 0.912 & \\
\hline $3 \mathrm{H}-4,101$ & 24.41 & 28.23 & 64.18 & 1 & 14.27 & 0.812 & \\
\hline $3 \mathrm{H}-4,111$ & 24.51 & 28.33 & 61.37 & 1 & 10.88 & 0.841 & \\
\hline $3 \mathrm{H}-4,121$ & 24.61 & 28.43 & 65.67 & 1 & 8.76 & 0.955 & \\
\hline $3 \mathrm{H}-4,131$ & 24.71 & 28.53 & 60.71 & 1 & 6.21 & 0.869 & \\
\hline $3 \mathrm{H}-4,141$ & 24.81 & 28.63 & 64.96 & 1 & 9.25 & 0.926 & \\
\hline $3 \mathrm{H}-5,1$ & 24.91 & 28.73 & 61.92 & 1 & 10.04 & 0.872 & \\
\hline $3 \mathrm{H}-5,11$ & 25.01 & 28.83 & 57.02 & 1 & 6.95 & 0.883 & \\
\hline $3 \mathrm{H}-5,21$ & 25.11 & 28.93 & 58.70 & 1 & 6.62 & 0.898 & \\
\hline $3 \mathrm{H}-5,31$ & 25.21 & 29.03 & 59.82 & 1 & 7.99 & 0.905 & \\
\hline $3 \mathrm{H}-5,41$ & 25.31 & 29.13 & 59.51 & 1 & 6.21 & 0.869 & \\
\hline $3 \mathrm{H}-5,51$ & 25.41 & 29.23 & 56.86 & 1 & 6.29 & 0.869 & \\
\hline $3 \mathrm{H}-5,61$ & 25.51 & 29.33 & 57.48 & 1 & 10.50 & 0.841 & \\
\hline $3 \mathrm{H}-5,71$ & 25.61 & 29.43 & 60.25 & 1 & 11.55 & 0.841 & \\
\hline $3 \mathrm{H}-5,81$ & 25.71 & 29.53 & 62.31 & 1 & 13.46 & 0.855 & Tie point \\
\hline $3 \mathrm{H}-5,91$ & 25.81 & 29.63 & 60.62 & 1 & 11.99 & 0.883 & Not in composite \\
\hline $3 \mathrm{H}-5,10 \mathrm{I}$ & 25.91 & 29.73 & 62.47 & 1 & 12.42 & 0.883 & Not in composite \\
\hline $3 \mathrm{H}-5,111$ & 26.01 & 29.83 & 66.04 & 1 & 12.06 & 0.912 & Not in composite \\
\hline $4 \mathrm{H}-5,71$ & 35.11 & 38.95 & 66.59 & 1 & 5.32 & 0.883 & Not in composite \\
\hline $4 \mathrm{H}-5,81$ & 35.21 & 39.05 & 69.99 & 2 & 6.58 & 0.940 & Not in composite \\
\hline $4 \mathrm{H}-5,91$ & 35.31 & 39.15 & 64.76 & 1 & 5.48 & 0.912 & Not in composite \\
\hline $4 \mathrm{H}-5,101$ & 35.41 & 39.25 & 64.06 & 2 & 5.30 & 0.940 & Tie point \\
\hline $4 \mathrm{H}-5,111$ & 35.51 & 39.35 & 61.53 & 1 & 2.52 & 0.969 & \\
\hline
\end{tabular}


Appendix C (continued).

\begin{tabular}{|c|c|c|c|c|c|c|c|}
\hline $\begin{array}{l}\text { Core, section, } \\
\text { interval }(\mathrm{cm})\end{array}$ & $\begin{array}{l}\text { ODP } \\
\text { depth } \\
\text { (mbsf) }\end{array}$ & $\begin{array}{l}\text { Composite } \\
\text { depth } \\
\text { (m) }\end{array}$ & $\begin{array}{c}\text { Mean } \\
\text { wt } \% \mathrm{CaCO}_{3}\end{array}$ & $\begin{array}{c}\text { Number } \\
\text { of wt \% CaCO } \\
\text { analyses }\end{array}$ & $\begin{array}{c}\text { Coarse } \\
\text { fraction } \\
(\mathrm{wt} \%>150 \mu \mathrm{m})\end{array}$ & $\begin{array}{l}\text { Dry-bulk } \\
\text { density } \\
\left(\mathrm{g} / \mathrm{cm}^{3}\right)\end{array}$ & Comment \\
\hline \multicolumn{8}{|l|}{ 121-758B-(Cont.) } \\
\hline $4 \mathrm{H}-5,121$ & 35.61 & 39.45 & 61.04 & 1 & 3.73 & 0.869 & \\
\hline $4 \mathrm{H}-5,131$ & 35.71 & 39.55 & 67.95 & 1 & 5.40 & 0.869 & \\
\hline $4 \mathrm{H}-5,141$ & 35.81 & 39.65 & 64.71 & $i$ & 5.56 & 0.898 & \\
\hline $4 \mathrm{H}-6,1$ & 35.91 & 39.75 & 68.03 & 1 & 8.28 & 0.876 & \\
\hline $4 \mathrm{H}-6,11$ & 36.01 & 39.85 & 66.15 & 1 & 5.31 & 0.926 & \\
\hline $4 \mathrm{H}-6,21$ & 36.11 & 39.95 & 67.84 & 1 & 4.34 & 0.969 & \\
\hline $4 \mathrm{H}-6,31$ & 36.21 & 40.05 & 71.13 & 1 & 8.40 & 0.947 & \\
\hline $4 \mathrm{H}-6,41$ & 36.31 & 40.15 & 70.62 & 1 & 8.83 & 0.883 & Tie point \\
\hline $5 \mathrm{H}-4,111$ & 43.61 & 49.27 & 63.35 & 2 & 4.273 & 0.905 & Not in composite \\
\hline $5 \mathrm{H}-4,121$ & 43.71 & 49.37 & 62.33 & 1 & 3.603 & 0.869 & Not in composite \\
\hline $5 \mathrm{H}-4,131$ & 43.81 & 49.47 & 55.90 & 1 & 3.072 & 0.862 & Tie point \\
\hline $5 \mathrm{H}-4,141$ & 43.91 & 49.57 & 62.48 & 1 & 4.078 & 0.919 & \\
\hline $5 \mathrm{H}-5,1$ & 44.01 & 49.67 & 64.95 & 1 & 3.723 & 0.940 & \\
\hline $5 \mathrm{H}-5,11$ & 44.11 & 49.77 & 64.87 & 1 & 4.110 & 0.919 & \\
\hline $5 \mathrm{H}-5,21$ & 44.21 & 49.87 & 66.68 & 1 & 3.634 & 0.955 & \\
\hline $5 \mathrm{H}-5,31$ & 44.31 & 49.97 & 67.88 & 1 & 3.542 & 0.926 & \\
\hline $5 \mathrm{H}-5,41$ & 44.41 & 50.07 & 67.80 & 1 & 5.370 & 0.883 & \\
\hline $5 \mathrm{H}-5,51$ & 44.51 & 50.17 & 69.19 & 1 & 5.759 & 0.983 & \\
\hline $5 \mathrm{H}-5,61$ & 44.61 & 50.27 & 68.94 & 1 & 4.084 & 0.940 & \\
\hline $5 \mathrm{H}-5,71$ & 44.71 & 50.37 & 69.79 & 1 & 4.784 & 0.912 & \\
\hline $5 \mathrm{H}-5,81$ & 44.81 & 50.47 & 68.70 & 2 & 3.954 & 0.940 & \\
\hline $5 \mathrm{H}-5,91$ & 44.91 & 50.57 & 67.36 & 1 & 4.044 & 0.926 & \\
\hline $5 \mathrm{H}-5,101$ & 45.01 & 50.67 & 67.43 & 1 & 3.109 & 0.912 & \\
\hline $5 \mathrm{H}-5,111$ & 45.11 & 50.77 & 61.32 & 2 & 2.092 & 0.933 & \\
\hline $5 \mathrm{H}-5,121$ & 45.21 & 50.87 & 69.18 & 1 & 3.392 & 0.912 & \\
\hline $5 \mathrm{H}-5,131$ & 45.31 & 50.97 & 69.05 & 1 & 3.605 & 0.883 & \\
\hline $5 \mathrm{H}-5,141$ & 45.41 & 51.07 & 67.93 & 1 & 3.301 & 0.865 & \\
\hline $5 \mathrm{H}-6,1$ & 45.51 & 51.17 & 69.99 & i & 4.160 & 0.955 & \\
\hline $5 \mathrm{H}-6,21$ & 45.71 & 51.37 & 73.35 & i & 8.298 & 0.855 & \\
\hline $5 \mathrm{H}-6,30$ & 45.80 & 51.46 & 71.68 & 1 & 6.304 & 0.912 & \\
\hline $5 \mathrm{H}-6,41$ & 45.91 & 51.57 & 74.09 & 1 & 6.753 & 0.955 & \\
\hline $5 \mathrm{H}-6,51$ & 46.01 & 51.67 & 68.75 & 1 & 3.913 & 0.898 & \\
\hline $5 \mathrm{H}-6,61$ & 46.11 & 51.77 & 66.34 & 1 & 2.753 & 0.940 & \\
\hline $5 \mathrm{H}-6,71$ & 46.21 & 51.87 & 69.05 & 1 & 2.887 & 0.926 & \\
\hline $5 \mathrm{H}-6,81$ & 46.31 & 51.97 & 68.31 & 1 & 2.855 & 0.955 & \\
\hline $5 \mathrm{H}-6,91$ & 46.41 & 52.07 & 70.24 & 2 & 4.492 & 0.926 & Tie point \\
\hline $6 \mathrm{H}-4,1$ & 52.21 & 60.89 & 72.28 & 1 & 6.052 & 0.826 & Not in composite \\
\hline $6 \mathrm{H}-4,11$ & 52.31 & 60.99 & 71.87 & i & 6.294 & 0.905 & Not in composite \\
\hline $6 \mathrm{H}-4,21$ & 52.41 & 61.09 & 71.32 & 2 & 5.848 & 0.912 & Not in composite \\
\hline $6 \mathrm{H}-4,31$ & 52.51 & 61.19 & 75.37 & 2 & 7.103 & 0.947 & Not in composite \\
\hline $6 \mathrm{H}-4,41$ & 52.61 & 61.29 & 73.03 & 1 & 6.676 & 0.926 & Not in composite \\
\hline $6 \mathrm{H}-4,51$ & 52.71 & 61.39 & 73.65 & $i$ & 6.916 & 0.905 & Not in composite \\
\hline $6 \mathrm{H}-4,61$ & 52.81 & 61.49 & 66.31 & 1 & 7.721 & 0.940 & Tie point \\
\hline $6 \mathrm{H}-4,71$ & 52.91 & 61.59 & 68.83 & 1 & 8.289 & 0.940 & \\
\hline $6 \mathrm{H}-4,81$ & 53.01 & 61.69 & 72.27 & 1 & 9.101 & 0.926 & \\
\hline $6 \mathrm{H}-4,91$ & 53.11 & 61.79 & 71.66 & 1 & 7.097 & 0.869 & \\
\hline $6 \mathrm{H}-4,101$ & 53.21 & 61.89 & 73.83 & $i$ & 6.416 & 0.898 & \\
\hline $6 \mathrm{H}-4,111$ & 53.31 & 61.99 & 76.58 & 1 & 6.708 & 0.926 & \\
\hline $6 \mathrm{H}-4,121$ & 53.41 & 62.09 & 75.71 & 1 & 3.474 & 0.955 & \\
\hline $6 \mathrm{H}-4,131$ & 53.51 & 62.19 & 71.46 & 1 & 3.800 & 0.898 & \\
\hline $6 \mathrm{H}-4,141$ & 53.61 & 62.29 & 71.40 & 1 & 4.833 & 0.862 & \\
\hline $6 \mathrm{H}-5,1$ & 53.71 & 62.39 & 71.52 & 1 & 5.399 & 0.922 & \\
\hline $6 \mathrm{H}-5,11$ & 53.81 & 62.49 & 71.29 & 1 & 6.164 & 0.898 & \\
\hline $6 \mathrm{H}-5,21$ & 53.91 & 62.59 & 68.38 & 1 & 2.765 & 0.898 & \\
\hline $6 \mathrm{H}-5,31$ & 54.01 & 62.69 & 67.59 & 1 & 2.567 & 0.919 & \\
\hline $6 \mathrm{H}-5,41$ & 54.11 & 62.79 & 69.46 & $i$ & 4.378 & 0.898 & \\
\hline $6 \mathrm{H}-5,51$ & 54.21 & 62.89 & 71.26 & $i$ & 6.255 & 0.898 & \\
\hline $6 \mathrm{H}-5,61$ & 54.31 & 62.99 & 72.05 & 1 & 5.522 & 0.926 & \\
\hline $6 \mathrm{H}-5,71$ & 54.41 & 63.09 & 69.91 & 1 & 5.690 & 0.912 & \\
\hline $6 \mathrm{H}-5,81$ & 54.51 & 63.19 & 69.13 & 1 & 3.834 & 0.940 & Tie point \\
\hline $6 \mathrm{H}-5,91$ & 54.61 & 63.29 & 65.24 & 1 & 3.516 & 0.926 & Not in composite \\
\hline $6 \mathrm{H}-5,101$ & 54.71 & 63.39 & 58.17 & 2 & 3.166 & 0.855 & Not in composite \\
\hline $6 \mathrm{H}-5,111$ & 54.81 & 63.49 & 62.26 & 1 & 3.081 & 0.862 & Not in composite \\
\hline $7 \mathrm{H}-4,91$ & 62.71 & 72.51 & 79.37 & 1 & 2.761 & 0.955 & Not in composite \\
\hline $7 \mathrm{H}-4,101$ & 62.81 & 72.61 & 76.97 & 1 & 2.346 & 1.012 & Not in composite \\
\hline $7 \mathrm{H}-4,111$ & 62.91 & 72.71 & 70.85 & 1 & 2.100 & 0.955 & Not in composite \\
\hline $7 \mathrm{H}-4,121$ & 63.01 & 72.81 & 71.91 & 1 & 2.796 & 0.969 & Tie point \\
\hline $7 \mathrm{H}-4,131$ & 63.11 & 72.91 & 42.71 & 2 & 0.924 & 1.047 & Ash $\mathrm{J}$, and below \\
\hline $7 \mathrm{H}-4,141$ & 63.21 & 73.01 & 77.08 & 1 & 1.696 & 0.926 & \\
\hline $7 \mathrm{H}-5,1$ & 63.31 & 73.11 & 75.12 & 1 & 2.374 & 1.012 & \\
\hline $7 \mathrm{H}-5,11$ & 63.41 & 73.21 & 78.35 & 1 & 3.790 & 0.962 & \\
\hline $7 \mathrm{H}-5,21$ & 63.51 & 73.31 & 75.11 & 1 & 1.667 & 0.969 & \\
\hline $7 \mathrm{H}-5,31$ & 63.61 & 73.41 & 75.37 & 1 & 1.184 & 0.962 & \\
\hline $7 \mathrm{H}-5,41$ & 63.71 & 73.51 & 78.58 & 1 & 2.543 & 0.955 & \\
\hline $7 \mathrm{H}-5,51$ & 63.81 & 73.61 & 80.91 & $i$ & 3.784 & 0.969 & \\
\hline
\end{tabular}


J. W. FARRELL, T. R. JANECEK

Appendix C (continued).

\begin{tabular}{|c|c|c|c|c|c|c|c|}
\hline $\begin{array}{l}\text { Core, section, } \\
\text { interval }(\mathrm{cm})\end{array}$ & $\begin{array}{l}\text { ODP } \\
\text { depth } \\
\text { (mbsf) }\end{array}$ & $\begin{array}{l}\text { Composite } \\
\text { depth } \\
\text { (m) }\end{array}$ & $\begin{array}{c}\text { Mean } \\
\text { wt } \% \mathrm{CaCO}_{3}\end{array}$ & $\begin{array}{c}\text { Number } \\
\text { of wt } \% \mathrm{CaCO}_{3} \\
\text { analyses }\end{array}$ & $\begin{array}{c}\text { Coarse } \\
\text { fraction } \\
\text { (wt } \%>150 \mu \mathrm{m})\end{array}$ & $\begin{array}{c}\text { Dry-bulk } \\
\text { density } \\
\left(\mathrm{g} / \mathrm{cm}^{3}\right)\end{array}$ & Comment \\
\hline \multicolumn{8}{|l|}{ 121-758B-(Cont.) } \\
\hline $7 \mathrm{H}-5,61$ & 63.91 & 73.71 & 79.64 & 1 & 4.541 & 0.969 & \\
\hline $7 \mathrm{H}-5,71$ & 64.01 & 73.81 & 78.25 & 1 & 4.424 & 0.898 & \\
\hline $7 \mathrm{H}-5,81$ & 64.11 & 73.91 & 77.91 & 2 & 4.170 & 0.955 & \\
\hline $7 \mathrm{H}-5,91$ & 64.21 & 74.01 & 74.12 & 1 & 2.495 & 0.997 & Tie point \\
\hline $7 \mathrm{H}-5,101$ & 64.31 & 74.11 & 73.11 & 1 & 0.854 & 0.912 & Not in composite \\
\hline $7 \mathrm{H}-5,111$ & 64.41 & 74.21 & 77.10 & 1 & 2.023 & 0.890 & Not in composite \\
\hline $7 \mathrm{H}-5,121$ & 64.51 & 74.31 & 81.42 & $i$ & 4.345 & 0.969 & Not in composite \\
\hline $8 \mathrm{H}-4,141$ & 72.91 & 83.23 & 73.94 & 1 & 2.798 & 0.883 & Not in composite \\
\hline $8 \mathrm{H}-5,1$ & 73.01 & 83.33 & 69.06 & 1 & 1.329 & 0.855 & Not in composite \\
\hline $8 \mathrm{H}-5,11$ & 73.11 & 83.43 & 70.06 & 1 & 2.177 & 0.947 & Tie point \\
\hline $8 \mathrm{H}-5,21$ & 73.21 & 83.53 & 72.97 & 1 & 2.494 & 0.969 & \\
\hline $8 \mathrm{H}-5,31$ & 73.31 & 83.63 & 72.85 & 1 & 3.468 & 0.947 & \\
\hline $8 \mathrm{H}-5,41$ & 73.41 & 83.73 & 71.61 & i & 3.656 & 0.898 & \\
\hline $8 \mathrm{H}-5,51$ & 73.51 & 83.83 & 62.22 & 2 & 1.623 & 0.983 & \\
\hline $8 \mathrm{H}-5,61$ & 73.61 & 83.93 & 74.82 & 1 & 1.351 & 0.940 & \\
\hline $8 \mathrm{H}-5,71$ & 73.71 & 84.03 & 79.03 & 1 & 2.842 & 0.997 & \\
\hline $8 \mathrm{H}-5,81$ & 73.81 & 84.13 & 78.64 & 2 & 3.020 & 0.969 & Tie point \\
\hline $8 \mathrm{H}-5,91$ & 73.91 & 84.23 & 79.43 & 1 & 3.345 & 0.955 & Not in composite \\
\hline $8 \mathrm{H}-5,99$ & 73.99 & 84.31 & 78.69 & 1 & 2.920 & 0.947 & Not in composite \\
\hline $8 \mathrm{H}-5,111$ & 74.11 & 84.43 & 73.95 & 1 & 0.758 & 0.947 & Not in composite \\
\hline
\end{tabular}


APPENDIX D

$\delta^{13} \mathrm{C}$ and $\delta^{18} \mathrm{O}$ Data, G. sacculifera $(300-355 \mu \mathrm{m})$, Hole 758A

\begin{tabular}{|c|c|c|c|c|c|c|c|}
\hline $\begin{array}{l}\text { Core, section, } \\
\text { interval }(\mathrm{cm})\end{array}$ & $\begin{array}{l}\text { ODP } \\
\text { depth } \\
\text { (mbsf) }\end{array}$ & $\begin{array}{l}\text { Composite } \\
\text { depth } \\
\text { (m) }\end{array}$ & $\begin{array}{l}\text { Number of } \\
\text { foraminifers } \\
\text { analyzed }\end{array}$ & $\begin{array}{l}\text { Number of } \\
\text { foraminifers } \\
\text { with sacs }\end{array}$ & $\begin{array}{c}\text { Transducer } \\
\text { pressure } \\
\text { (mbar) }\end{array}$ & $\begin{array}{l}\delta^{13} \mathrm{C} \\
\%_{0} \text { to } \\
\text { (PDB) }\end{array}$ & $\begin{array}{l}\delta^{18} \mathrm{O} \\
\%_{0} \text { to } \\
\text { (PDB) }\end{array}$ \\
\hline \multicolumn{8}{|l|}{$121-758 \mathrm{~A}-$} \\
\hline $1 \mathrm{H}-1,1$ & 0.01 & 0.01 & 11 & 0 & 4.8 & 1.46 & -2.26 \\
\hline $1 \mathrm{H}-1,1$ & 0.01 & 0.01 & 11 & 0 & 4.8 & 1.72 & -2.02 \\
\hline $1 \mathrm{H}-1,1$ & 0.01 & 0.01 & 11 & 0 & 3.7 & 1.51 & -2.47 \\
\hline $1 \mathrm{H}-1,11$ & 0.11 & 0.11 & 13 & 0 & 6.7 & 1.40 & -2.14 \\
\hline $1 \mathrm{H}-1,11$ & 0.11 & 0.11 & 12 & 0 & 4.8 & 1.79 & -2.38 \\
\hline $1 \mathrm{H}-1,21$ & 0.21 & 0.21 & 13 & 0 & 6.3 & 1.34 & -2.19 \\
\hline $1 \mathrm{H}-1,21$ & 0.21 & 0.21 & 12 & 0 & 5.9 & 1.64 & -2.08 \\
\hline $1 \mathrm{H}-1,31$ & 0.31 & 0.31 & 11 & 0 & 6.7 & 1.49 & -1.58 \\
\hline $1 \mathrm{H}-1,31$ & 0.31 & 0.31 & 11 & 0 & 5.2 & 1.34 & -1.33 \\
\hline $1 \mathrm{H}-1,41$ & 0.41 & 0.41 & 13 & 0 & 7.0 & 1.42 & -0.44 \\
\hline $1 \mathrm{H}-1,41$ & 0.41 & 0.41 & 12 & c & 6.3 & 1.78 & -0.23 \\
\hline $1 \mathrm{H}-1,51$ & 0.51 & 0.51 & 11 & c & 4.8 & 1.49 & -0.49 \\
\hline $1 \mathrm{H}-1,51$ & 0.51 & 0.51 & 11 & 0 & 4.8 & 1.83 & -0.51 \\
\hline $1 \mathrm{H}-1,61$ & 0.61 & 0.61 & 12 & 0 & 5.6 & 1.75 & -0.55 \\
\hline $1 \mathrm{H}-1,61$ & 0.61 & 0.61 & 10 & 0 & 4.1 & 1.68 & -0.83 \\
\hline $1 \mathrm{H}-1,71$ & 0.71 & 0.71 & 10 & 0 & 4.1 & 1.45 & -0.87 \\
\hline $1 \mathrm{H}-1,71$ & 0.71 & 0.71 & 9 & 0 & 3.3 & 1.76 & -1.03 \\
\hline $1 \mathrm{H}-1,71$ & 0.71 & 0.71 & 9 & 0 & 3.0 & 1.52 & -0.76 \\
\hline $1 \mathrm{H}-1,81$ & 0.81 & 0.81 & 10 & 0 & 3.0 & 1.80 & -0.84 \\
\hline $1 \mathrm{H}-1,81$ & 0.81 & 0.81 & 10 & 0 & 4.8 & 1.43 & -1.01 \\
\hline $1 \mathrm{H}-1,81$ & 0.81 & 0.81 & 10 & 0 & 3.7 & 1.81 & -1.00 \\
\hline $1 \mathrm{H}-1,91$ & 0.91 & 0.91 & 13 & 0 & 5.2 & 1.56 & -0.84 \\
\hline $1 \mathrm{H}-1,91$ & 0.91 & 0.91 & 12 & 0 & 4.4 & 1.59 & -0.93 \\
\hline $1 \mathrm{H}-1,101$ & 1.01 & 1.01 & 13 & 0 & 5.2 & 1.65 & -0.99 \\
\hline $1 \mathrm{H}-1,101$ & 1.01 & 1.01 & 14 & 0 & 5.9 & 1.63 & -1.04 \\
\hline $1 \mathrm{H}-1,111$ & 1.11 & 1.11 & 12 & 0 & 5.2 & 1.54 & -1.02 \\
\hline $1 \mathrm{H}-1,111$ & 1.11 & 1.11 & 12 & 0 & 5.9 & 1.53 & -1.17 \\
\hline $1 \mathrm{H}-1,121$ & 1.21 & 1.21 & 13 & 0 & 5.6 & 1.43 & -1.10 \\
\hline $1 \mathrm{H}-1,121$ & 1.21 & 1.21 & 12 & 0 & 5.2 & 1.37 & -0.95 \\
\hline $1 \mathrm{H}-1,131$ & 1.31 & 1.31 & 15 & 0 & 6.7 & 1.37 & -0.87 \\
\hline $1 \mathrm{H}-1,131$ & 1.31 & 1.31 & 12 & 0 & 5.2 & 1.40 & -0.85 \\
\hline $1 \mathrm{H}-1,141$ & 1.41 & 1.41 & 13 & 0 & 7.8 & 1.68 & -0.78 \\
\hline $1 \mathrm{H}-1,141$ & 1.41 & 1.41 & 12 & 0 & 7.4 & 1.67 & -0.94 \\
\hline $1 \mathrm{H}-2,1$ & 1.51 & 1.51 & 13 & 0 & 3.3 & 1.12 & -1.01 \\
\hline $1 \mathrm{H}-2,1$ & 1.51 & 1.51 & 12 & 0 & 5.9 & 1.26 & -1.04 \\
\hline $1 \mathrm{H}-2,41$ & 1.91 & 1.91 & 11 & 0 & 7.8 & 1.33 & -1.09 \\
\hline $1 \mathrm{H}-2,41$ & 1.91 & 1.91 & 11 & 0 & 4.4 & 1.45 & -1.43 \\
\hline $1 \mathrm{H}-2,41$ & 1.91 & 1.91 & 11 & 0 & 4.1 & 1.57 & -1.49 \\
\hline $1 \mathrm{H}-2,61$ & 2.11 & 2.11 & 12 & 0 & 4.1 & 1.34 & -1.01 \\
\hline $1 \mathrm{H}-2,61$ & 2.11 & 2.11 & 12 & 0 & 4.8 & 1.63 & -1.38 \\
\hline $1 \mathrm{H}-2,61$ & 2.11 & 2.11 & 12 & 0 & 4.1 & 1.75 & -1.75 \\
\hline $1 \mathrm{H}-2,71$ & 2.21 & 2.21 & 13 & 0 & 5.6 & 1.24 & -2.16 \\
\hline $1 \mathrm{H}-2,71$ & 2.21 & 2.21 & 12 & 0 & 4.4 & 1.68 & -1.28 \\
\hline $1 \mathrm{H}-2,71$ & 2.21 & 2.21 & 14 & 0 & 5.2 & 1.53 & -1.13 \\
\hline $1 \mathrm{H}-2,81$ & 2.31 & 2.31 & 13 & 0 & 4.4 & 1.30 & -1.67 \\
\hline $1 \mathrm{H}-2,81$ & 2.31 & 2.31 & 12 & 0 & 4.8 & 1.48 & -1.20 \\
\hline $1 \mathrm{H}-2,81$ & 2.31 & 2.31 & 15 & 0 & 6.3 & 1.44 & -1.27 \\
\hline $1 \mathrm{H}-2,91$ & 2.41 & 2.41 & 15 & 0 & 5.9 & 1.29 & -1.76 \\
\hline $1 \mathrm{H}-2,91$ & 2.41 & 2.41 & 12 & 0 & 4.4 & 1.62 & -1.67 \\
\hline $1 \mathrm{H}-2,91$ & 2.41 & 2.41 & 10 & 0 & 2.6 & 1.53 & -1.75 \\
\hline $1 \mathrm{H}-2,101$ & 2.51 & 2.51 & 13 & 0 & 4.8 & 1.24 & -1.88 \\
\hline $1 \mathrm{H}-2,101$ & 2.51 & 2.51 & 12 & 0 & 4.4 & 1.03 & -1.56 \\
\hline $1 \mathrm{H}-2,101$ & 2.51 & 2.51 & 13 & 0 & 4.8 & 1.51 & -1.62 \\
\hline $1 \mathrm{H}-2,111$ & 2.61 & 2.61 & 11 & 0 & 4.4 & 1.23 & -1.55 \\
\hline $1 \mathrm{H}-2,111$ & 2.61 & 2.61 & 10 & 0 & 3.0 & 1.10 & -1.58 \\
\hline $1 \mathrm{H}-2,121$ & 2.71 & 2.71 & 14 & 0 & 4.1 & 0.97 & -1.80 \\
\hline $1 \mathrm{H}-2,121$ & 2.71 & 2.71 & 13 & 0 & 3.0 & 1.10 & -2.16 \\
\hline $1 \mathrm{H}-2,121$ & 2.71 & 2.71 & 10 & 0 & 3.3 & 1.13 & -1.80 \\
\hline $1 \mathrm{H}-2,131$ & 2.81 & 2.81 & 12 & 0 & 5.9 & 1.07 & -1.19 \\
\hline $1 \mathrm{H}-2,131$ & 2.81 & 2.81 & 11 & 0 & 3.7 & 0.87 & -1.64 \\
\hline $1 \mathrm{H}-2,131$ & 2.81 & 2.81 & 11 & 0 & 4.8 & 1.24 & -1.66 \\
\hline $1 \mathrm{H}-2,141$ & 2.91 & 2.91 & 15 & 0 & 8.9 & 1.04 & -1.28 \\
\hline $1 \mathrm{H}-2,141$ & 2.91 & 2.91 & 15 & 0 & 7.8 & 1.30 & -0.68 \\
\hline $1 \mathrm{H}-2,141$ & 2.91 & 2.91 & 12 & 0 & 6.3 & 1.09 & -0.82 \\
\hline $1 \mathrm{H}-3,1$ & 3.01 & 3.01 & 15 & 0 & 8.1 & 1.23 & -0.33 \\
\hline $1 \mathrm{H}-3,1$ & 3.01 & 3.01 & 12 & 0 & 5.2 & 1.17 & -0.41 \\
\hline $1 \mathrm{H}-3,11$ & 3.11 & 3.11 & 15 & 0 & 7.8 & 1.36 & -0.47 \\
\hline $1 \mathrm{H}-3,11$ & 3.11 & 3.11 & 12 & 0 & 5.6 & 1.41 & -0.62 \\
\hline $1 \mathrm{H}-3,21$ & 3.21 & 3.21 & 14 & 0 & 7.0 & 1.42 & -0.64 \\
\hline $1 \mathrm{H}-3,21$ & 3.21 & 3.21 & 12 & 0 & 5.6 & 1.32 & -0.69 \\
\hline $1 \mathrm{H}-3,31$ & 3.31 & 3.31 & 15 & 0 & 8.5 & 1.52 & -0.53 \\
\hline $1 \mathrm{H}-3,31$ & 3.31 & 3.31 & 12 & 0 & 5.6 & 1.17 & -0.77 \\
\hline $1 \mathrm{H}-3,41$ & 3.41 & 3.41 & 13 & 0 & 6.7 & 1.15 & -0.65 \\
\hline $1 \mathrm{H}-3,41$ & 3.41 & 3.41 & 12 & 0 & 5.6 & 1.20 & -0.85 \\
\hline $1 \mathrm{H}-3,51$ & 3.51 & 3.51 & 13 & 0 & 6.3 & 1.21 & -1.19 \\
\hline
\end{tabular}


Appendix D (continued).

\begin{tabular}{|c|c|c|c|c|c|c|c|}
\hline $\begin{array}{l}\text { Core, section, } \\
\text { interval (cm) }\end{array}$ & $\begin{array}{l}\text { ODP } \\
\text { depth } \\
\text { (mbsf) }\end{array}$ & $\begin{array}{l}\text { Composite } \\
\text { depth } \\
\text { (m) }\end{array}$ & $\begin{array}{l}\text { Number of } \\
\text { foraminifers } \\
\text { analyzed }\end{array}$ & $\begin{array}{l}\text { Number of } \\
\text { foraminifers } \\
\text { with sacs }\end{array}$ & $\begin{array}{l}\text { Transducer } \\
\text { pressure } \\
\text { (mbar) }\end{array}$ & $\begin{array}{l}\delta^{13} \mathrm{C} \\
\%_{0} \text { to } \\
\text { (PDB) }\end{array}$ & $\begin{array}{l}\delta^{18} \mathrm{O} \\
\% 0 \text { to } \\
\text { (PDB) }\end{array}$ \\
\hline \multicolumn{8}{|l|}{ 121-758A-(Cont.) } \\
\hline $1 \mathrm{H}-3,51$ & 3.51 & 3.51 & 12 & 0 & 4.4 & 1.22 & -1.32 \\
\hline $1 \mathrm{H}-3,61$ & 3.61 & 3.61 & 15 & 0 & 8.9 & 1.47 & -0.94 \\
\hline $1 \mathrm{H}-3,71$ & 3.71 & 3.71 & 14 & 0 & 8.1 & 1.31 & -0.99 \\
\hline $1 \mathrm{H}-3,81$ & 3.81 & 3.81 & 10 & 0 & 4.4 & 1.33 & -1.31 \\
\hline $1 \mathrm{H}-3,81$ & 3.81 & 3.81 & 10 & 0 & 4.8 & 1.49 & -1.23 \\
\hline $1 \mathrm{H}-3,91$ & 3.91 & 3.91 & 12 & 0 & 4.4 & 1.65 & -1.79 \\
\hline $1 \mathrm{H}-3,91$ & 3.91 & 3.91 & 12 & 0 & 4.4 & 1.03 & -2.15 \\
\hline $1 \mathrm{H}-3,91$ & 3.91 & 3.91 & 12 & 0 & 4.4 & 1.55 & -1.90 \\
\hline $1 \mathrm{H}-3,101$ & 4.01 & 4.01 & 9 & 0 & 3.0 & 1.52 & -1.13 \\
\hline $1 \mathrm{H}-3,101$ & 4.01 & 4.01 & 8 & 0 & 2.6 & 1.52 & -1.59 \\
\hline $1 \mathrm{H}-3,101$ & 4.01 & 4.01 & 8 & 0 & 2.2 & 1.40 & -1.08 \\
\hline $1 \mathrm{H}-3,111$ & 4.11 & 4.11 & 15 & 0 & 6.3 & 1.42 & -1.49 \\
\hline $1 \mathrm{H}-3,111$ & 4.11 & 4.11 & 12 & 0 & 6.3 & 1.49 & -1.62 \\
\hline $1 \mathrm{H}-3,121$ & 4.21 & 4.21 & 15 & 0 & 7.4 & 1.57 & -1.75 \\
\hline $1 \mathrm{H}-3,121$ & 4.21 & 4.21 & 12 & 0 & 5.9 & 1.59 & -1.72 \\
\hline $1 \mathrm{H}-3,121$ & 4.21 & 4.21 & 12 & 0 & 5.6 & 1.50 & -1.63 \\
\hline $1 \mathrm{H}-3,131$ & 4.31 & 4.31 & 14 & 0 & 7.0 & 1.49 & -1.08 \\
\hline $1 \mathrm{H}-3,131$ & 4.31 & 4.31 & 12 & 0 & 5.6 & 1.36 & -1.46 \\
\hline $1 \mathrm{H}-3,131$ & 4.31 & 4.31 & 12 & 0 & 5.6 & 1.36 & -1.30 \\
\hline $1 \mathrm{H}-3,141$ & 4.41 & 4.41 & 15 & 0 & 8.1 & 1.40 & -1.07 \\
\hline $1 \mathrm{H}-3,141$ & 4.41 & 4.41 & 12 & 0 & 6.3 & 1.42 & -0.90 \\
\hline $1 \mathrm{H}-3,141$ & 4.41 & 4.41 & 12 & 0 & 5.6 & 1.44 & -0.93 \\
\hline $1 \mathrm{H}-4,1$ & 4.51 & 4.51 & 12 & 0 & 5.6 & 1.28 & -1.10 \\
\hline $1 \mathrm{H}-4,1$ & 4.51 & 4.51 & 12 & 0 & 7.0 & 1.54 & -0.82 \\
\hline $1 \mathrm{H}-4,1$ & 4.51 & 4.51 & 12 & 0 & 4.4 & 1.60 & -1.21 \\
\hline $1 \mathrm{H}-4,11$ & 4.61 & 4.61 & 15 & 0 & 7.0 & 1.32 & -1.59 \\
\hline $1 \mathrm{H}-4,11$ & 4.61 & 4.61 & 12 & 0 & 4.8 & 1.38 & -1.33 \\
\hline $1 \mathrm{H}-4,21$ & 4.71 & 4.71 & 15 & 0 & 7.4 & 1.26 & -1.29 \\
\hline $1 \mathrm{H}-4,31$ & 4.81 & 4.81 & 15 & 0 & 8.5 & 1.52 & -0.90 \\
\hline $1 \mathrm{H}-4,41$ & 4.91 & 4.91 & 15 & 0 & 8.5 & 1.45 & -0.55 \\
\hline $1 \mathrm{H}-4,41$ & 4.91 & 4.91 & 12 & 0 & 6.3 & 1.14 & -0.61 \\
\hline $1 \mathrm{H}-4,51$ & 5.01 & 5.01 & 15 & 0 & 8.1 & 1.38 & -0.59 \\
\hline $1 \mathrm{H}-4,51$ & 5.01 & 5.01 & 12 & 0 & 5.6 & 1.40 & -0.66 \\
\hline $1 \mathrm{H}-4,61$ & 5.11 & 5.11 & 15 & 0 & 7.4 & 1.28 & -0.85 \\
\hline $1 \mathrm{H}-4,61$ & 5.11 & 5.11 & 12 & 0 & 6.3 & 1.15 & -1.02 \\
\hline $1 \mathrm{H}-4,71$ & 5.21 & 5.21 & 15 & 0 & 7.8 & 1.18 & -0.75 \\
\hline $1 \mathrm{H}-4,71$ & 5.21 & 5.21 & 12 & 0 & 7.0 & 0.99 & -1.12 \\
\hline $1 \mathrm{H}-4,71$ & 5.21 & 5.21 & 12 & 0 & 6.3 & 1.34 & -0.77 \\
\hline $1 \mathrm{H}-4,81$ & 5.31 & 5.31 & 15 & 0 & 9.6 & 1.22 & -0.70 \\
\hline $1 \mathrm{H}-4,81$ & 5.31 & 5.31 & 12 & 0 & 6.7 & 1.40 & -0.69 \\
\hline $1 \mathrm{H}-4,91$ & 5.41 & 5.41 & 15 & 0 & 8.9 & 1.45 & -0.99 \\
\hline $1 \mathrm{H}-4,101$ & 5.51 & 5.51 & 11 & 0 & 4.1 & 1.31 & -1.29 \\
\hline $1 \mathrm{H}-4,111$ & 5.61 & 5.61 & 15 & 0 & 8.9 & 1.79 & -1.07 \\
\hline $1 \mathrm{H}-4,121$ & 5.71 & 5.71 & 15 & 0 & 8.1 & 1.54 & -0.95 \\
\hline 1H-CC, 1 & 5.76 & 5.76 & 15 & 0 & 7.4 & 1.47 & -1.05 \\
\hline $1 \mathrm{H}-\mathrm{CC}, 11$ & 5.86 & 5.86 & 12 & 0 & 6.3 & 1.42 & -1.40 \\
\hline $1 \mathrm{H}-\mathrm{CC}, 21$ & 5.96 & 5.96 & 10 & 0 & 4.1 & 1.32 & -1.74 \\
\hline $2 \mathrm{H}-1,1$ & 6.01 & 7.43 & 13 & 0 & 5.2 & 1.62 & -1.73 \\
\hline $2 \mathrm{H}-1,11$ & 6.11 & 7.53 & 9 & 0 & 3.0 & 1.45 & -1.60 \\
\hline $2 \mathrm{H}-1,11$ & 6.11 & 7.53 & 8 & 4 & 2.2 & 1.44 & -1.84 \\
\hline $2 \mathrm{H}-1,21$ & 6.21 & 7.63 & 15 & 0 & 7.8 & 1.28 & -0.63 \\
\hline $2 \mathrm{H}-1,2 \mathrm{I}$ & 6.21 & 7.63 & 12 & 0 & 5.9 & 1.61 & -0.34 \\
\hline $2 \mathrm{H}-1,31$ & 6.31 & 7.73 & 15 & 0 & 8.1 & 1.62 & -0.52 \\
\hline $2 \mathrm{H}-1,31$ & 6.31 & 7.73 & 12 & 0 & 6.3 & 1.45 & -0.61 \\
\hline $2 \mathrm{H}-1,41$ & 6.41 & 7.83 & 15 & 0 & 8.1 & 1.63 & -0.62 \\
\hline $2 \mathrm{H}-1,41$ & 6.41 & 7.83 & 12 & 0 & 6.3 & 1.49 & -0.65 \\
\hline $2 \mathrm{H}-1,51$ & 6.51 & 7.93 & 15 & 0 & 10.0 & 1.49 & -1.04 \\
\hline $2 \mathrm{H}-1,51$ & 6.51 & 7.93 & 12 & 0 & 7.4 & 1.73 & -1.06 \\
\hline $2 \mathrm{H}-1,61$ & 6.61 & 8.03 & 15 & 0 & 6.7 & 1.64 & -1.12 \\
\hline $2 \mathrm{H}-1,61$ & 6.61 & 8.03 & 12 & 0 & 4.4 & 1.68 & -1.51 \\
\hline $2 \mathrm{H}-1,71$ & 6.71 & 8.13 & 15 & 0 & 8.5 & 1.87 & -1.30 \\
\hline $2 \mathrm{H}-1,71$ & 6.71 & 8.13 & 12 & 0 & 4.1 & 1.58 & -1.30 \\
\hline $2 \mathrm{H}-1,81$ & 6.81 & 8.23 & 13 & 0 & 6.3 & 2.06 & -1.64 \\
\hline $2 \mathrm{H}-1,91$ & 6.91 & 8.33 & 9 & 0 & 2.6 & 1.84 & -1.45 \\
\hline $2 \mathrm{H}-1,101$ & 7.01 & 8.43 & 8 & 0 & 4.1 & 1.71 & -1.50 \\
\hline $2 \mathrm{H}-1,121$ & 7.21 & 8.63 & 8 & 0 & 1.9 & 1.57 & -1.27 \\
\hline $2 \mathrm{H}-1,131$ & 7.31 & 8.73 & 9 & 0 & 3.0 & 1.71 & -1.42 \\
\hline $2 \mathrm{H}-1,131$ & 7.31 & 8.73 & 13 & 0 & 6.3 & 1.41 & -1.55 \\
\hline $2 \mathrm{H}-1,141$ & 7.41 & 8.83 & 15 & 0 & 6.7 & 1.48 & -1.42 \\
\hline $2 \mathrm{H}-1,141$ & 7.41 & 8.83 & 12 & 0 & 5.9 & 1.63 & -1.33 \\
\hline $2 \mathrm{H}-1,141$ & 7.41 & 8.83 & 12 & 0 & 5.9 & 1.45 & -1.14 \\
\hline $2 \mathrm{H}-2,1$ & 7.51 & 8.93 & 15 & 0 & 7.4 & 1.28 & -1.12 \\
\hline $2 \mathrm{H}-2,1$ & 7.51 & 8.93 & 12 & 0 & 5.6 & 1.43 & -1.29 \\
\hline $2 \mathrm{H}-2,11$ & 7.61 & 9.03 & 15 & 0 & 9.3 & 1.28 & -1.16 \\
\hline $2 \mathrm{H}-2,11$ & 6.61 & 9.03 & 12 & 0 & 7.4 & 1.36 & -1.09 \\
\hline $2 \mathrm{H}-2,21$ & 7.71 & 9.13 & 15 & 0 & 10.0 & 1.24 & -1.28 \\
\hline
\end{tabular}


Appendix D (continued).

\begin{tabular}{|c|c|c|c|c|c|c|c|}
\hline $\begin{array}{l}\text { Core, section, } \\
\text { interval }(\mathrm{cm})\end{array}$ & $\begin{array}{l}\text { ODP } \\
\text { depth } \\
\text { (mbsf) }\end{array}$ & $\begin{array}{l}\text { Composite } \\
\text { depth } \\
\text { (m) }\end{array}$ & $\begin{array}{l}\text { Number of } \\
\text { foraminifers } \\
\text { analyzed }\end{array}$ & $\begin{array}{l}\text { Number of } \\
\text { foraminifers } \\
\text { with sacs }\end{array}$ & $\begin{array}{l}\text { Transducer } \\
\text { pressure } \\
\text { (mbar) }\end{array}$ & $\begin{array}{l}\delta^{13} \mathrm{C} \\
\%_{0} \text { to } \\
\text { (PDB) }\end{array}$ & $\begin{array}{l}\delta^{18} \mathrm{O} \\
\%_{0} \text { to } \\
\text { (PDB) }\end{array}$ \\
\hline \multicolumn{8}{|l|}{ 121-758A-(Cont.) } \\
\hline $2 \mathrm{H}-2,2 \mathrm{I}$ & 7.71 & 9.13 & 12 & 0 & 6.3 & 1.56 & -1.38 \\
\hline $2 \mathrm{H}-2,3 \mathrm{I}$ & 7.81 & 9.23 & 11 & 0 & 4.1 & 1.35 & -1.45 \\
\hline $2 \mathrm{H}-2,3 \mathrm{I}$ & 7.81 & 9.23 & 11 & 0 & 3.7 & 1.54 & -1.74 \\
\hline $2 \mathrm{H}-2,41$ & 7.91 & 9.33 & 12 & 0 & 4.8 & 1.50 & -1.57 \\
\hline $2 \mathrm{H}-2,41$ & 7.91 & 9.33 & 12 & 0 & 5.6 & 1.46 & -1.66 \\
\hline $2 \mathrm{H}-2,51$ & 8.01 & 9.43 & 10 & 0 & 3.3 & 1.45 & -2.18 \\
\hline $2 \mathrm{H}-2,51$ & 8.01 & 9.43 & 10 & 0 & 4.1 & 1.62 & -2.11 \\
\hline $2 \mathrm{H}-2,51$ & 8.01 & 9.43 & 8 & 0 & 2.6 & 1.48 & -1.70 \\
\hline $2 \mathrm{H}-2,61$ & 8.11 & 9.53 & 15 & 0 & 6.3 & 1.30 & -1.42 \\
\hline $2 \mathrm{H}-2,61$ & 8.11 & 9.53 & 12 & 0 & 5.2 & 1.32 & -1.50 \\
\hline $2 \mathrm{H}-2,7 \mathrm{I}$ & 8.21 & 9.63 & 15 & 0 & 7.8 & 1.45 & -1.31 \\
\hline $2 \mathrm{H}-2,71$ & 8.21 & 9.63 & 12 & 0 & 5.9 & 1.53 & -1.32 \\
\hline $2 \mathrm{H}-2,71$ & 8.21 & 9.63 & 12 & 0 & 5.6 & 1.23 & -1.38 \\
\hline $2 \mathrm{H}-2,81$ & 8.31 & 9.73 & 15 & 0 & 8.5 & 1.26 & -1.60 \\
\hline $2 \mathrm{H}-2,81$ & 8.31 & 9.73 & 12 & 0 & 4.8 & 1.25 & -1.66 \\
\hline $2 \mathrm{H}-2,91$ & 8.41 & 9.83 & 12 & 0 & 4.8 & 1.28 & -1.66 \\
\hline $2 \mathrm{H}-2,91$ & 8.41 & 9.83 & 12 & 0 & 4.1 & 1.15 & -1.76 \\
\hline $2 \mathrm{H}-2,101$ & 8.51 & 9.93 & 10 & 0 & 3.0 & 1.21 & -1.53 \\
\hline $2 \mathrm{H}-2,101$ & 8.51 & 9.93 & 10 & 0 & 3.7 & 1.25 & -1.41 \\
\hline $2 \mathrm{H}-2,111$ & 8.61 & 10.03 & 10 & 0 & 4.8 & 1.10 & -1.79 \\
\hline $2 \mathrm{H}-2,111$ & 8.61 & 10.03 & 10 & 0 & 4.8 & 1.36 & -1.41 \\
\hline $2 \mathrm{H}-2,111$ & 8.61 & 10.03 & 13 & 10 & 4.4 & 1.16 & -1.78 \\
\hline $2 \mathrm{H}-2,121$ & 8.71 & 10.13 & 11 & 0 & 6.3 & 1.28 & -1.07 \\
\hline $2 \mathrm{H}-2,131$ & 8.81 & 10.23 & 10 & 0 & 4.8 & 1.15 & -0.58 \\
\hline $2 \mathrm{H}-2,131$ & 8.81 & 10.23 & 11 & 0 & 6.3 & 1.22 & -0.54 \\
\hline $2 \mathrm{H}-2,141$ & 8.91 & 10.33 & 12 & 0 & 5.9 & 1.29 & -0.57 \\
\hline $2 \mathrm{H}-2,141$ & 8.91 & 10.33 & 12 & 0 & 7.8 & 1.44 & -0.70 \\
\hline $2 \mathrm{H}-3,1$ & 9.01 & 10.43 & 11 & 0 & 6.3 & 1.41 & -0.68 \\
\hline $2 \mathrm{H}-3,1$ & 9.01 & 10.43 & 11 & 0 & 7.0 & 1.41 & -0.87 \\
\hline $2 \mathrm{H}-3,11$ & 9.11 & 10.53 & 11 & 0 & 5.6 & 1.36 & -1.05 \\
\hline $2 \mathrm{H}-3,11$ & 9.11 & 10.53 & 12 & 0 & 6.3 & 1.04 & -0.93 \\
\hline $2 \mathrm{H}-3,21$ & 9.21 & 10.63 & 11 & 0 & 6.7 & 1.21 & -0.97 \\
\hline $2 \mathrm{H}-3,21$ & 9.21 & 10.63 & 12 & 0 & 6.3 & 1.21 & -1.06 \\
\hline $2 \mathrm{H}-3,31$ & 9.31 & 10.73 & 11 & 0 & 6.7 & 1.36 & -1.27 \\
\hline $2 \mathrm{H}-3,31$ & 9.31 & 10.73 & 12 & 0 & 8.5 & 1.47 & -1.47 \\
\hline $2 \mathrm{H}-3,41$ & 9.41 & 10.83 & 12 & 0 & 5.2 & 1.29 & -1.03 \\
\hline $2 \mathrm{H}-3,41$ & 9.41 & 10.83 & 12 & 0 & 4.8 & 0.96 & -2.11 \\
\hline $2 \mathrm{H}-3,41$ & 9.41 & 10.83 & 12 & 6 & 5.6 & 1.27 & -1.15 \\
\hline $2 \mathrm{H}-3,51$ & 9.51 & 10.93 & 12 & 0 & 7.0 & 1.43 & -1.57 \\
\hline $2 \mathrm{H}-3,51$ & 9.51 & 10.93 & 11 & 0 & 5.6 & 1.31 & -1.68 \\
\hline $2 \mathrm{H}-3,61$ & 9.61 & 11.03 & 12 & 0 & 5.2 & 1.34 & -1.75 \\
\hline $2 \mathrm{H}-3,61$ & 9.61 & 11.03 & 12 & 0 & 5.6 & 1.59 & -1.52 \\
\hline $2 \mathrm{H}-3,71$ & 9.71 & 11.13 & 12 & 0 & 5.9 & 1.28 & -1.58 \\
\hline $2 \mathrm{H}-3,71$ & 9.71 & 11.13 & 12 & 0 & 6.3 & 1.31 & -1.41 \\
\hline $2 \mathrm{H}-3,81$ & 9.81 & 11.23 & 12 & 0 & 7.0 & 1.42 & -1.36 \\
\hline $2 \mathrm{H}-3,91$ & 9.91 & 11.33 & 12 & 0 & 5.2 & 1.22 & -0.99 \\
\hline $2 \mathrm{H}-3,91$ & 9.91 & 11.33 & 12 & 0 & 6.3 & 1.24 & -1.04 \\
\hline $2 \mathrm{H}-3,101$ & 10.01 & 11.43 & 12 & 0 & 5.2 & 1.26 & -0.88 \\
\hline $2 \mathrm{H}-3,101$ & 10.01 & 11.43 & 12 & 0 & 5.2 & 1.26 & -0.93 \\
\hline $2 \mathrm{H}-3,111$ & 10.11 & 11.53 & 12 & 0 & 6.7 & 1.44 & -1.17 \\
\hline $2 \mathrm{H}-3,111$ & 10.11 & 11.53 & 12 & 0 & 6.7 & 1.04 & -1.31 \\
\hline $2 \mathrm{H}-3,111$ & 10.11 & 11.53 & 12 & 12 & 6.7 & 1.35 & -1.05 \\
\hline $2 \mathrm{H}-3,121$ & 10.21 & 11.63 & 13 & 0 & 6.7 & 1.34 & -1.14 \\
\hline $2 \mathrm{H}-3,121$ & 10.21 & 11.63 & 12 & 0 & 7.4 & 1.29 & -1.13 \\
\hline $2 \mathrm{H}-3,13 \mathrm{l}$ & 10.31 & 11.73 & 10 & 0 & 5.9 & 1.23 & -0.67 \\
\hline $2 \mathrm{H}-3,131$ & 10.31 & 11.73 & 12 & 0 & 9.3 & 1.05 & -1.28 \\
\hline $2 \mathrm{H}-3,141$ & 10.41 & 11.83 & 9 & 0 & 3.7 & 1.22 & -0.94 \\
\hline $2 \mathrm{H}-4,1$ & 10.51 & 11.93 & 10 & 0 & 3.7 & 1.18 & -1.49 \\
\hline $2 \mathrm{H}-4,1$ & 10.51 & 11.93 & 12 & 0 & 4.8 & 1.43 & -1.81 \\
\hline $2 \mathrm{H}-4,11$ & 10.61 & 12.03 & 11 & 0 & 4.8 & 1.17 & -1.86 \\
\hline $2 \mathrm{H}-4,11$ & 10.61 & 12.03 & 11 & 0 & 4.4 & 1.30 & -1.93 \\
\hline $2 \mathrm{H}-4,11$ & 10.61 & 12.03 & 10 & 0 & 3.0 & 1.54 & -1.96 \\
\hline $2 \mathrm{H}-4,2 \mathrm{I}$ & 10.71 & 12.13 & 13 & 0 & 3.7 & 1.09 & -1.75 \\
\hline $2 \mathrm{H}-4,2 \mathrm{I}$ & 10.71 & 12.13 & 12 & 0 & 4.8 & 1.34 & -1.80 \\
\hline $2 \mathrm{H}-4,5 \mathrm{I}$ & 11.01 & 12.43 & 13 & 0 & 6.7 & 1.03 & -1.11 \\
\hline $2 \mathrm{H}-4,51$ & 11.01 & 12.43 & 12 & 0 & 6.3 & 1.30 & -0.84 \\
\hline $2 \mathrm{H}-4,61$ & 11.11 & 12.53 & 13 & 0 & 7.4 & 1.26 & -0.78 \\
\hline $2 \mathrm{H}-4,71$ & 11.21 & 12.63 & 13 & 0 & 8.1 & 1.67 & -0.67 \\
\hline $2 \mathrm{H}-4,71$ & 11.21 & 12.63 & 12 & 0 & 8.5 & 1.52 & -0.87 \\
\hline $2 \mathrm{H}-4,81$ & 11.31 & 12.73 & 11 & 0 & 4.8 & 1.49 & -1.08 \\
\hline $2 \mathrm{H}-4,91$ & 11.41 & 12.83 & 13 & 0 & 6.7 & 1.54 & -1.21 \\
\hline $2 \mathrm{H}-4,101$ & 11.51 & 12.93 & 10 & 0 & 4.4 & 1.24 & -1.54 \\
\hline $2 \mathrm{H}-4,111$ & 11.61 & 13.03 & 13 & 0 & 8.5 & 1.55 & -1.71 \\
\hline $2 \mathrm{H}-4,111$ & 11.61 & 13.03 & 13 & 0 & 7.0 & 1.30 & -1.67 \\
\hline $2 \mathrm{H}-4,121$ & 11.71 & 13.13 & 13 & 0 & 7.0 & 1.17 & -1.61 \\
\hline $2 \mathrm{H}-4,121$ & 11.71 & 13.13 & 12 & 0 & 6.7 & 1.33 & -1.71 \\
\hline
\end{tabular}


Appendix D (continued).

\begin{tabular}{|c|c|c|c|c|c|c|c|}
\hline $\begin{array}{l}\text { Core, section, } \\
\text { interval }(\mathrm{cm})\end{array}$ & $\begin{array}{l}\text { ODP } \\
\text { depth } \\
\text { (mbsf) }\end{array}$ & $\begin{array}{l}\text { Composite } \\
\text { depth } \\
\text { (m) }\end{array}$ & $\begin{array}{l}\text { Number of } \\
\text { foraminifers } \\
\text { analyzed }\end{array}$ & $\begin{array}{l}\text { Number of } \\
\text { foraminifers } \\
\text { with sacs }\end{array}$ & $\begin{array}{l}\text { Transducer } \\
\text { pressure } \\
\text { (mbar) }\end{array}$ & $\begin{array}{l}\delta^{13} \mathrm{C} \\
\%_{0} \text { to } \\
\text { (PDB) }\end{array}$ & $\begin{array}{l}\delta^{18} \mathrm{O} \\
\% 0 \text { to } \\
\text { (PDB) }\end{array}$ \\
\hline \multicolumn{8}{|l|}{ 121-758A-(Cont.) } \\
\hline $2 \mathrm{H}-4,131$ & 11.81 & 13.23 & 13 & 0 & 6.3 & 1.32 & -1.42 \\
\hline $2 \mathrm{H}-4,13 \mathrm{I}$ & 11.81 & 13.23 & 12 & 0 & 6.3 & 1.39 & -1.34 \\
\hline $2 \mathrm{H}-4,141$ & 11.91 & 13.33 & 12 & 0 & 5.9 & 1.10 & -1.53 \\
\hline $2 \mathrm{H}-4,141$ & 11.91 & 13.33 & 12 & 0 & 5.2 & 1.10 & -1.46 \\
\hline $2 \mathrm{H}-5,1$ & 12.01 & 13.43 & 15 & 0 & 7.8 & 1.19 & -1.69 \\
\hline $2 \mathrm{H}-5,1$ & 12.01 & 13.43 & 12 & 0 & 7.4 & 1.28 & -1.45 \\
\hline $2 \mathrm{H}-5,11$ & 12.11 & 13.53 & 15 & 0 & 9.3 & 1.03 & -0.74 \\
\hline $2 \mathrm{H}-5,21$ & 12.21 & 13.63 & 15 & 0 & 9.6 & 1.22 & -0.40 \\
\hline $2 \mathrm{H}-5,21$ & 12.21 & 13.63 & 13 & 6 & 9.3 & 1.21 & -0.36 \\
\hline $2 \mathrm{H}-5,31$ & 12.31 & 13.73 & 15 & 0 & 10.4 & 1.32 & -0.73 \\
\hline $2 \mathrm{H}-5,31$ & 12.31 & 13.73 & 12 & 0 & 8.5 & 1.32 & -0.77 \\
\hline $2 \mathrm{H}-5,41$ & 12.41 & 13.83 & 13 & 0 & 8.1 & 1.20 & -0.57 \\
\hline $2 \mathrm{H}-5,41$ & 12.41 & 13.83 & 12 & 0 & 7.0 & 1.12 & -0.69 \\
\hline $2 \mathrm{H}-5,51$ & 12.51 & 13.93 & 15 & 0 & 10.0 & 1.35 & -0.94 \\
\hline $2 \mathrm{H}-5,51$ & 12.51 & 13.93 & 11 & 0 & 7.4 & 1.54 & -0.54 \\
\hline $2 \mathrm{H}-5,61$ & 12.61 & 14.03 & 13 & 0 & 7.8 & 1.16 & -1.38 \\
\hline $2 \mathrm{H}-5,61$ & 12.61 & 14.03 & 7 & 0 & 4.1 & 1.33 & -1.15 \\
\hline $2 \mathrm{H}-5,61$ & 12.61 & 14.03 & 12 & 7 & 7.8 & 1.22 & -1.01 \\
\hline $2 \mathrm{H}-5,71$ & 12.71 & 14.13 & 12 & 8 & 6.7 & 1.23 & -1.06 \\
\hline $2 \mathrm{H}-5,81$ & 12.81 & 14.23 & 15 & 0 & 11.5 & 1.53 & -0.93 \\
\hline $2 \mathrm{H}-5,81$ & 12.81 & 14.23 & 12 & 0 & 8.5 & 1.37 & -0.98 \\
\hline $2 \mathrm{H}-5,91$ & 12.91 & 14.33 & 15 & 0 & 10.7 & 1.42 & -1.07 \\
\hline $2 \mathrm{H}-5,91$ & 12.91 & 14.33 & 12 & 0 & 8.9 & 1.49 & -1.00 \\
\hline $2 \mathrm{H}-5,101$ & 13.01 & 14.43 & 10 & 0 & 5.2 & 1.18 & -1.58 \\
\hline $2 \mathrm{H}-5,101$ & 13.01 & 14.43 & 12 & 0 & 9.6 & 1.40 & -1.47 \\
\hline $2 \mathrm{H}-5,111$ & 13.11 & 14.53 & 10 & 0 & 5.2 & 1.41 & -1.82 \\
\hline $2 \mathrm{H}-5,111$ & 13.11 & 14.53 & 12 & 5 & 5.9 & 1.64 & -1.62 \\
\hline $2 \mathrm{H}-5,121$ & 13.21 & 14.63 & 8 & 0 & 2.6 & 1.16 & -1.66 \\
\hline $2 \mathrm{H}-5,121$ & 13.21 & 14.63 & 8 & 0 & 4.8 & 1.57 & -1.57 \\
\hline $2 \mathrm{H}-5,131$ & 13.31 & 14.73 & 12 & 0 & 4.8 & 1.13 & -1.83 \\
\hline $2 \mathrm{H}-5,131$ & 13.31 & 14.73 & 12 & 0 & 6.3 & 1.22 & -1.54 \\
\hline $2 \mathrm{H}-6,1$ & 13.51 & 14.93 & 12 & 0 & 6.7 & 1.54 & -1.27 \\
\hline $2 \mathrm{H}-6,1$ & 13.51 & 14.93 & 12 & 0 & 6.7 & 1.41 & -0.96 \\
\hline $2 \mathrm{H}-6,11$ & 13.61 & 15.03 & 15 & 0 & 9.6 & 1.57 & -1.35 \\
\hline $2 \mathrm{H}-6,11$ & 13.61 & 15.03 & 12 & 0 & 6.7 & 1.60 & -1.24 \\
\hline $2 \mathrm{H}-6,21$ & 13.71 & 15.13 & 13 & 0 & 9.3 & 1.64 & -1.90 \\
\hline $2 \mathrm{H}-6,21$ & 13.71 & 15.13 & 12 & 0 & 7.0 & 1.65 & -1.68 \\
\hline $2 \mathrm{H}-6,31$ & 13.81 & 15.23 & 12 & 0 & 7.0 & 1.68 & -1.72 \\
\hline $2 \mathrm{H}-6,31$ & 13.81 & 15.23 & 12 & 0 & 5.9 & 1.57 & -1.66 \\
\hline $2 \mathrm{H}-6,41$ & 13.91 & 15.33 & 12 & 0 & 7.0 & 1.74 & -1.44 \\
\hline $2 \mathrm{H}-6,41$ & 13.91 & 15.33 & 12 & 0 & 5.6 & 1.61 & -1.23 \\
\hline $2 \mathrm{H}-6,51$ & 14.01 & 15.43 & 10 & 0 & 4.4 & 1.85 & -1.37 \\
\hline $2 \mathrm{H}-6,51$ & 14.01 & 15.43 & 12 & 0 & 7.4 & 1.83 & -1.20 \\
\hline $2 \mathrm{H}-6,61$ & 14.11 & 15.53 & 11 & 0 & 7.0 & 1.92 & -1.54 \\
\hline 2H-6, 61 & 14.11 & 15.53 & 12 & 0 & 7.4 & 1.87 & -1.59 \\
\hline $2 \mathrm{H}-6,71$ & 14.21 & 15.63 & 15 & 0 & 7.8 & 1.61 & -1.32 \\
\hline $2 \mathrm{H}-6,71$ & 14.21 & 15.63 & 12 & 0 & 6.3 & 1.63 & -1.48 \\
\hline $2 \mathrm{H}-6,81$ & 14.31 & 15.73 & 15 & 0 & 8.1 & 1.79 & -1.43 \\
\hline $2 \mathrm{H}-6,91$ & 14.41 & 15.83 & 12 & 0 & 5.6 & 1.60 & -1.54 \\
\hline $2 \mathrm{H}-6,101$ & 14.51 & 15.93 & 15 & 0 & 8.1 & 1.77 & -1.58 \\
\hline $2 \mathrm{H}-6,111$ & 14.61 & 16.03 & 13 & 0 & 7.4 & 1.33 & -1.59 \\
\hline $2 \mathrm{H}-6,121$ & 14.71 & 16.13 & 13 & 0 & 8.9 & 1.58 & -1.29 \\
\hline $2 \mathrm{H}-6,131$ & 14.81 & 16.23 & 12 & 0 & 7.8 & 1.33 & -1.14 \\
\hline $2 \mathrm{H}-6,131$ & 14.81 & 16.23 & 12 & 0 & 8.9 & 1.37 & -1.12 \\
\hline $2 \mathrm{H}-6,141$ & 14.91 & 16.33 & 15 & 0 & 10.0 & 1.18 & -1.25 \\
\hline $2 \mathrm{H}-7,1$ & 15.01 & 16.43 & 15 & 0 & 8.1 & 1.37 & -1.31 \\
\hline $2 \mathrm{H}-7,11$ & 15.11 & 16.53 & 14 & 0 & 9.6 & 1.40 & -1.46 \\
\hline $2 \mathrm{H}-7,2 \mathrm{I}$ & 15.21 & 16.63 & 14 & 0 & 8.5 & 1.48 & -1.65 \\
\hline $2 \mathrm{H}-7,2 \mathrm{I}$ & 15.21 & 16.63 & 12 & 0 & 7.4 & 1.44 & -1.73 \\
\hline $2 \mathrm{H}-7,31$ & 15.31 & 16.73 & 15 & 0 & 6.7 & 1.25 & -1.63 \\
\hline $2 \mathrm{H}-7,31$ & 15.31 & 16.73 & 12 & 0 & 5.2 & 1.48 & -1.70 \\
\hline $2 \mathrm{H}-7,4 \mathrm{I}$ & 15.41 & 16.83 & 15 & 0 & 8.5 & 1.24 & -1.29 \\
\hline $2 \mathrm{H}-7,41$ & 15.41 & 16.83 & 12 & 0 & 7.0 & 1.37 & -1.56 \\
\hline $2 \mathrm{H}-7,41$ & 15.41 & 16.83 & 12 & 0 & 7.4 & 1.77 & -1.69 \\
\hline $2 \mathrm{H}-7,51$ & 15.51 & 16.93 & 12 & 0 & 7.8 & 1.47 & -1.73 \\
\hline $2 \mathrm{H}-7,5 \mathrm{I}$ & 15.51 & 16.93 & 12 & 0 & 8.1 & 1.51 & -1.50 \\
\hline $2 \mathrm{H}-7,61$ & 15.61 & 17.03 & 12 & 0 & 7.4 & 1.37 & -1.65 \\
\hline $2 \mathrm{H}-7,61$ & 15.61 & 17.03 & 9 & 0 & 4.1 & 1.58 & -1.59 \\
\hline $2 \mathrm{H}-7,71$ & 15.71 & 17.13 & 12 & 0 & 6.3 & 1.28 & -1.28 \\
\hline $2 \mathrm{H}-7,71$ & 15.71 & 17.13 & 12 & 0 & 7.8 & 1.68 & -1.16 \\
\hline $2 \mathrm{H}-\mathrm{c}, 01$ & 15.78 & 17.20 & 12 & 0 & 8.1 & 1.77 & -1.51 \\
\hline $2 \mathrm{H}-\mathrm{c}, 11$ & 15.88 & 17.30 & 12 & 0 & 6.3 & 1.30 & -1.61 \\
\hline $2 \mathrm{H}-\mathrm{c}, 11$ & 15.88 & 17.30 & 12 & 0 & 6.3 & 1.42 & -1.50 \\
\hline $3 \mathrm{H}-1,1$ & 15.61 & 17.52 & 12 & 0 & 5.6 & 1.44 & -1.37 \\
\hline $3 \mathrm{H}-1,11$ & 15.71 & 17.62 & 15 & 0 & 9.3 & 1.31 & -1.28 \\
\hline $3 \mathrm{H}-1,11$ & 15.71 & 17.62 & 12 & 0 & 7.0 & 1.35 & -1.43 \\
\hline
\end{tabular}


Appendix D (continued).

\begin{tabular}{|c|c|c|c|c|c|c|c|}
\hline $\begin{array}{l}\text { Core, section, } \\
\text { interval }(\mathrm{cm})\end{array}$ & $\begin{array}{l}\text { ODP } \\
\text { depth } \\
\text { (mbsf) }\end{array}$ & $\begin{array}{l}\text { Composite } \\
\text { depth } \\
\text { (m) }\end{array}$ & $\begin{array}{l}\text { Number of } \\
\text { foraminifers } \\
\text { analyzed }\end{array}$ & $\begin{array}{c}\text { Number of } \\
\text { foraminifers } \\
\text { with sacs }\end{array}$ & $\begin{array}{c}\text { Transducer } \\
\text { pressure } \\
\text { (mbar) }\end{array}$ & $\begin{array}{l}\delta^{13} \mathrm{C} \\
\% 0 \text { to } \\
\text { (PDB) }\end{array}$ & $\begin{array}{l}\delta^{18} \mathrm{O} \\
\%_{0} \text { to } \\
\text { (PDB) }\end{array}$ \\
\hline \multicolumn{8}{|l|}{ 121-758A-(Cont.) } \\
\hline $3 \mathrm{H}-1,11$ & 15.71 & 17.62 & 12 & 0 & 9.6 & 1.50 & -1.44 \\
\hline $3 \mathrm{H}-1,2 \mathrm{I}$ & 15.81 & 17.72 & 12 & 0 & 5.2 & 1.41 & -1.40 \\
\hline $3 \mathrm{H}-1,31$ & 15.91 & 17.82 & 12 & 0 & 6.7 & 1.66 & -1.55 \\
\hline $3 \mathrm{H}-1,41$ & 16.01 & 17.92 & 10 & 0 & 4.4 & 1.26 & -1.51 \\
\hline $3 \mathrm{H}-1,51$ & 16.11 & 18.02 & 12 & 0 & 7.4 & 1.40 & -1.40 \\
\hline $3 \mathrm{H}-1,51$ & 16.11 & 18.02 & 12 & 0 & 7.8 & 1.61 & -1.50 \\
\hline $3 \mathrm{H}-1,61$ & 16.21 & 18.12 & 12 & 0 & 6.3 & 1.34 & -1.65 \\
\hline $3 \mathrm{H}-1,61$ & 16.21 & 18.12 & 12 & 0 & 7.0 & 1.40 & -1.44 \\
\hline $3 \mathrm{H}-1,71$ & 16.31 & 18.22 & 12 & 0 & 7.8 & 1.51 & -1.07 \\
\hline $3 \mathrm{H}-1,71$ & 16.31 & 18.22 & 12 & 0 & 8.5 & 1.50 & -1.24 \\
\hline $3 \mathrm{H}-1,81$ & 16.41 & 18.32 & 12 & 0 & 8.9 & 1.36 & -1.08 \\
\hline $3 \mathrm{H}-1,81$ & 16.41 & 18.32 & 12 & 0 & 9.3 & 1.52 & -1.20 \\
\hline $3 \mathrm{H}-1,91$ & 16.51 & 18.42 & 12 & 0 & 8.5 & 1.44 & -1.33 \\
\hline $3 \mathrm{H}-1,91$ & 16.51 & 18.42 & 12 & 0 & 9.3 & 1.65 & -1.41 \\
\hline $3 \mathrm{H}-1,101$ & 16.61 & 18.52 & 12 & 0 & 7.8 & 1.61 & -1.29 \\
\hline $3 \mathrm{H}-1,111$ & 16.71 & 18.62 & 12 & 0 & 6.3 & 1.21 & -1.40 \\
\hline $3 \mathrm{H}-1,111$ & 16.71 & 18.62 & 12 & 5 & 6.7 & 1.56 & -1.10 \\
\hline $3 \mathrm{H}-1,121$ & 16.81 & 18.72 & 12 & 0 & 5.6 & 1.28 & -1.77 \\
\hline $3 \mathrm{H}-1,121$ & 16.81 & 18.72 & 12 & 0 & 6.7 & 1.55 & -1.54 \\
\hline $3 \mathrm{H}-1,131$ & 16.91 & 18.82 & 12 & 0 & 6.7 & 1.46 & -1.36 \\
\hline $3 \mathrm{H}-1,141$ & 17.01 & 18.92 & 12 & 0 & 7.0 & 1.18 & -1.21 \\
\hline $3 \mathrm{H}-2,1$ & 17.11 & 19.02 & 12 & 0 & 7.8 & 1.30 & -0.88 \\
\hline $3 \mathrm{H}-2,1$ & 17.11 & 19.02 & 12 & 0 & 6.7 & 1.16 & -0.89 \\
\hline $3 \mathrm{H}-2,11$ & 17.21 & 19.12 & 12 & 0 & 8.9 & 1.51 & -0.73 \\
\hline $3 \mathrm{H}-2,11$ & 17.21 & 19.12 & 12 & 0 & 8.1 & 1.28 & -0.73 \\
\hline $3 \mathrm{H}-2,21$ & 17.31 & 19.22 & 12 & 0 & 6.7 & 1.35 & -1.18 \\
\hline $3 \mathrm{H}-2,21$ & 17.31 & 19.22 & 12 & 0 & 7.8 & 1.58 & -1.46 \\
\hline $3 \mathrm{H}-2,31$ & 17.41 & 19.32 & 12 & 0 & 5.9 & 1.57 & -1.26 \\
\hline $3 \mathrm{H}-2,41$ & 17.51 & 19.42 & 12 & 0 & 6.3 & 1.68 & -1.37 \\
\hline $3 \mathrm{H}-2,51$ & 17.61 & 19.52 & 12 & 0 & 8.1 & 1.78 & -1.80 \\
\hline $3 \mathrm{H}-2,51$ & 17.61 & 19.52 & 12 & 0 & 6.3 & 1.73 & -1.87 \\
\hline $3 \mathrm{H}-2,61$ & 17.71 & 19.62 & 12 & 0 & 7.0 & 1.39 & -1.12 \\
\hline $3 \mathrm{H}-2,71$ & 17.81 & 19.72 & 12 & 0 & 7.8 & 1.43 & -1.07 \\
\hline $3 \mathrm{H}-2,81$ & 17.91 & 19.82 & 12 & 0 & 8.1 & 1.56 & -0.99 \\
\hline $3 \mathrm{H}-2,81$ & 17.91 & 19.82 & 12 & 0 & 8.1 & 1.46 & -1.09 \\
\hline $3 \mathrm{H}-2,91$ & 18.01 & 19.92 & 12 & 0 & 6.7 & 1.72 & -1.21 \\
\hline $3 \mathrm{H}-2,101$ & 18.11 & 20.02 & 12 & 0 & 6.7 & 1.72 & -1.51 \\
\hline $3 \mathrm{H}-2,101$ & 18.11 & 20.02 & 12 & 0 & 7.0 & 1.86 & -1.77 \\
\hline $3 \mathrm{H}-2,111$ & 18.21 & 20.12 & 12 & 0 & 7.4 & 1.44 & -1.64 \\
\hline $3 \mathrm{H}-2,121$ & 18.31 & 20.22 & 12 & 0 & 8.5 & 1.45 & -1.37 \\
\hline $3 \mathrm{H}-2,121$ & 18.31 & 20.22 & 12 & 0 & 8.5 & 1.34 & -1.26 \\
\hline $3 \mathrm{H}-2,131$ & 18.41 & 20.32 & 12 & 0 & 6.7 & 1.51 & -1.58 \\
\hline $3 \mathrm{H}-2,131$ & 18.41 & 20.32 & 12 & 0 & 7.8 & 1.48 & -1.42 \\
\hline $3 \mathrm{H}-2,141$ & 18.51 & 20.42 & 12 & 0 & 6.7 & 1.51 & -1.48 \\
\hline $3 \mathrm{H}-2,141$ & 18.51 & 20.42 & 12 & 0 & 4.4 & 1.57 & -1.45 \\
\hline $3 \mathrm{H}-3,1$ & 18.61 & 20.52 & 12 & 0 & 6.3 & 1.76 & -1.15 \\
\hline $3 \mathrm{H}-3,1$ & 18.61 & 20.52 & 13 & 0 & 7.0 & 1.89 & -0.98 \\
\hline $3 \mathrm{H}-3,11$ & 18.71 & 20.62 & 12 & 0 & 7.4 & 1.91 & -1.60 \\
\hline $3 \mathrm{H}-3,11$ & 18.71 & 20.62 & 12 & 0 & 7.8 & 1.90 & -1.57 \\
\hline $3 \mathrm{H}-3,21$ & 18.81 & 20.72 & 12 & 0 & 6.3 & 1.47 & -1.66 \\
\hline $3 \mathrm{H}-3,21$ & 18.81 & 20.72 & 12 & 0 & 5.9 & 1.64 & -1.98 \\
\hline $3 \mathrm{H}-3,31$ & 18.91 & 20.82 & 12 & 0 & 7.4 & 1.60 & -1.37 \\
\hline $3 \mathrm{H}-3,31$ & 18.91 & 20.82 & 12 & 0 & 7.0 & 1.53 & -1.34 \\
\hline $3 \mathrm{H}-3,41$ & 19.01 & 20.92 & 12 & 0 & 7.0 & 1.57 & -1.39 \\
\hline $3 \mathrm{H}-3,51$ & 19.11 & 21.02 & 12 & 0 & 8.1 & 1.54 & -1.30 \\
\hline $3 \mathrm{H}-3,61$ & 19.21 & 21.12 & 12 & 0 & 6.7 & 1.68 & -1.27 \\
\hline $3 \mathrm{H}-3,71$ & 19.31 & 21.22 & 12 & 0 & 7.0 & 1.79 & -1.45 \\
\hline $3 \mathrm{H}-3,81$ & 19.41 & 21.32 & 12 & 0 & 6.3 & 1.75 & -1.41 \\
\hline $3 \mathrm{H}-3,91$ & 19.51 & 21.42 & 12 & 0 & 7.0 & 1.83 & -1.73 \\
\hline $3 \mathrm{H}-3,91$ & 19.51 & 21.42 & 12 & 0 & 6.7 & 1.79 & -1.68 \\
\hline $3 \mathrm{H}-3,101$ & 19.61 & 21.52 & 12 & 0 & 6.3 & 1.57 & -1.50 \\
\hline $3 \mathrm{H}-3,101$ & 19.61 & 21.52 & 12 & 0 & 6.7 & 1.65 & -1.51 \\
\hline $3 \mathrm{H}-3,111$ & 19.71 & 21.62 & 12 & 0 & 6.3 & 1.39 & -1.51 \\
\hline $3 \mathrm{H}-3,111$ & 19.71 & 21.62 & 12 & 0 & 7.0 & 1.10 & -1.71 \\
\hline $3 \mathrm{H}-3,121$ & 19.81 & 21.72 & 12 & 0 & 6.7 & 1.39 & -1.51 \\
\hline $3 \mathrm{H}-3,121$ & 19.81 & 21.72 & 12 & 0 & 4.4 & 1.27 & -1.37 \\
\hline $3 \mathrm{H}-3,131$ & 19.91 & 21.82 & 12 & 0 & 7.4 & 1.14 & -1.60 \\
\hline $3 \mathrm{H}-3,131$ & 19.91 & 21.82 & 12 & 0 & 7.8 & 1.26 & -1.58 \\
\hline $3 \mathrm{H}-3,141$ & 20.01 & 21.92 & 12 & 0 & 5.2 & 1.30 & -1.29 \\
\hline $3 \mathrm{H}-3,141$ & 20.01 & 21.92 & 12 & 0 & 6.3 & 1.52 & -1.25 \\
\hline $3 \mathrm{H}-4,1$ & 20.11 & 22.02 & 12 & 0 & 7.0 & 1.78 & -1.60 \\
\hline $3 \mathrm{H}-4,11$ & 20.21 & 22.12 & 12 & 0 & 6.7 & 1.78 & -1.99 \\
\hline $3 \mathrm{H}-4,11$ & 20.21 & 22.12 & 12 & 0 & 7.8 & 1.86 & -2.41 \\
\hline $3 \mathrm{H}-4,11$ & 20.21 & 22.12 & 12 & 0 & 6.7 & 1.78 & -2.10 \\
\hline $3 \mathrm{H}-4,21$ & 20.31 & 22.22 & 12 & 0 & 7.4 & 1.58 & -1.87 \\
\hline
\end{tabular}


Appendix D (continued).

\begin{tabular}{|c|c|c|c|c|c|c|c|}
\hline $\begin{array}{l}\text { Core, section, } \\
\text { interval (cm) }\end{array}$ & $\begin{array}{l}\text { ODP } \\
\text { depth } \\
\text { (mbsf) }\end{array}$ & $\begin{array}{l}\text { Composite } \\
\text { depth } \\
\text { (m) }\end{array}$ & $\begin{array}{l}\text { Number of } \\
\text { foraminifers } \\
\text { analyzed }\end{array}$ & $\begin{array}{l}\text { Number of } \\
\text { foraminifers } \\
\text { with sacs }\end{array}$ & $\begin{array}{c}\text { Transducer } \\
\text { pressure } \\
\text { (mbar) }\end{array}$ & $\begin{array}{l}\delta^{13} \mathrm{C} \\
\%_{0} \text { to } \\
\text { (PDB) }\end{array}$ & $\begin{array}{l}\delta^{18} \mathrm{O} \\
\% 0 \text { to } \\
\text { (PDB) }\end{array}$ \\
\hline \multicolumn{8}{|l|}{ 121-758A-(Cont.) } \\
\hline $3 \mathrm{H}-4,21$ & 20.31 & 22.22 & 12 & 0 & 5.9 & 1.53 & -1.77 \\
\hline $3 \mathrm{H}-4,31$ & 20.41 & 22.32 & 12 & 0 & 5.9 & 1.30 & -1.88 \\
\hline $3 \mathrm{H}-4,31$ & 20.41 & 22.32 & 12 & 0 & 6.3 & 1.23 & -1.91 \\
\hline $3 \mathrm{H}-4,41$ & 20.51 & 22.42 & 12 & 0 & 7.8 & 1.20 & -1.34 \\
\hline $3 \mathrm{H}-4,41$ & 20.51 & 22.42 & 12 & 0 & 6.7 & 1.18 & -1.59 \\
\hline $3 \mathrm{H}-4,51$ & 20.61 & 22.52 & 12 & 0 & 7.4 & 1.71 & -0.98 \\
\hline $3 \mathrm{H}-4,51$ & 20.61 & 22.52 & 12 & 0 & 6.7 & 1.55 & -1.33 \\
\hline $3 \mathrm{H}-4,61$ & 20.71 & 22.62 & 12 & 0 & 8.1 & 1.83 & -1.53 \\
\hline $3 \mathrm{H}-4,61$ & 20.71 & 22.62 & 12 & 0 & 7.4 & 1.83 & -1.24 \\
\hline $3 \mathrm{H}-4,7 \mathrm{I}$ & 20.81 & 22.72 & 12 & 0 & 7.4 & 1.96 & -1.60 \\
\hline $3 \mathrm{H}-4,71$ & 20.81 & 22.72 & 12 & 0 & 4.8 & 1.61 & -1.50 \\
\hline $3 \mathrm{H}-4,81$ & 20.91 & 22.82 & 12 & 0 & 7.0 & 2.14 & -2.20 \\
\hline $3 \mathrm{H}-4,81$ & 20.91 & 22.82 & 12 & 0 & 5.6 & 1.80 & -2.15 \\
\hline $3 \mathrm{H}-4,91$ & 21.01 & 22.92 & 12 & 0 & 5.9 & 1.81 & -1.72 \\
\hline $3 \mathrm{H}-4,91$ & 21.01 & 22.92 & 12 & 0 & 4.8 & 1.68 & -1.65 \\
\hline $3 \mathrm{H}-4,101$ & 21.11 & 23.02 & 12 & 0 & 5.9 & 1.81 & -2.02 \\
\hline $3 \mathrm{H}-4,101$ & 21.11 & 23.02 & 12 & 0 & 5.9 & 1.68 & -1.59 \\
\hline $3 \mathrm{H}-4,101$ & 21.11 & 23.02 & 12 & 0 & 5.2 & 1.86 & -1.29 \\
\hline $3 \mathrm{H}-4,111$ & 21.21 & 23.12 & 12 & 0 & 5.9 & 1.79 & -1.24 \\
\hline $3 \mathrm{H}-4,111$ & 21.21 & 23.12 & 12 & 0 & 6.3 & 1.57 & -1.36 \\
\hline $3 \mathrm{H}-4,121$ & 21.31 & 23.22 & 12 & 0 & 6.7 & 1.81 & -1.24 \\
\hline $3 \mathrm{H}-4,121$ & 21.31 & 23.22 & 12 & 0 & 5.9 & 1.71 & -1.19 \\
\hline $3 \mathrm{H}-4,131$ & 21.41 & 23.32 & 12 & 0 & 6.3 & 1.80 & -1.52 \\
\hline $3 \mathrm{H}-4,141$ & 21.51 & 23.42 & 12 & 0 & 6.7 & 2.08 & -1.70 \\
\hline $3 \mathrm{H}-4,141$ & 21.51 & 23.42 & 12 & 0 & 1.5 & 1.93 & -1.32 \\
\hline $3 \mathrm{H}-4,141$ & 21.51 & 23.42 & 13 & 0 & 8.9 & 2.25 & -1.80 \\
\hline $3 \mathrm{H}-5,1$ & 21.61 & 23.52 & 12 & 0 & 7.0 & 2.05 & -1.70 \\
\hline $3 \mathrm{H}-5,1$ & 21.61 & 23.52 & 12 & 0 & 6.7 & 1.88 & -1.88 \\
\hline $3 \mathrm{H}-5,11$ & 21.71 & 23.62 & 12 & 0 & 5.9 & 1.53 & -1.50 \\
\hline $3 \mathrm{H}-5,11$ & 21.71 & 23.62 & 12 & 0 & 7.0 & 1.42 & -1.79 \\
\hline $3 \mathrm{H}-5,21$ & 21.81 & 23.72 & 12 & 0 & 6.3 & 1.57 & -1.51 \\
\hline $3 \mathrm{H}-5,21$ & 21.81 & 23.72 & 12 & 0 & 7.0 & 1.08 & -1.43 \\
\hline $3 \mathrm{H}-5,31$ & 21.91 & 23.82 & 12 & 0 & 7.8 & 1.81 & -1.27 \\
\hline $3 \mathrm{H}-5,31$ & 21.91 & 23.82 & 12 & 0 & 7.4 & 1.55 & -1.34 \\
\hline $3 \mathrm{H}-5,41$ & 22.01 & 23.92 & 12 & 0 & 7.4 & 1.88 & -1.27 \\
\hline $3 \mathrm{H}-5,41$ & 22.01 & 23.92 & 12 & 0 & 7.8 & 1.80 & -1.43 \\
\hline $3 \mathrm{H}-5,51$ & 22.11 & 24.02 & 12 & 0 & 6.7 & 1.97 & -1.56 \\
\hline $3 \mathrm{H}-5,51$ & 22.11 & 24.02 & 12 & 0 & 7.0 & 1.93 & -1.62 \\
\hline $3 \mathrm{H}-5,61$ & 22.21 & 24.12 & 12 & 0 & 7.0 & 1.80 & -1.44 \\
\hline $3 \mathrm{H}-5,61$ & 22.21 & 24.12 & 12 & 0 & 7.4 & 2.01 & -1.49 \\
\hline $3 \mathrm{H}-5,71$ & 22.31 & 24.22 & 12 & 0 & 5.9 & 1.71 & -1.82 \\
\hline $3 \mathrm{H}-5,71$ & 22.31 & 24.22 & 12 & 0 & 7.0 & 1.92 & -1.55 \\
\hline $3 \mathrm{H}-5,81$ & 22.41 & 24.32 & 12 & 0 & 7.4 & 1.94 & -1.85 \\
\hline $3 \mathrm{H}-5,81$ & 22.41 & 24.32 & 12 & 0 & 5.6 & 1.70 & -1.82 \\
\hline $3 \mathrm{H}-5,91$ & 22.51 & 24.42 & 12 & 0 & 7.0 & 1.61 & -1.31 \\
\hline $3 \mathrm{H}-5,91$ & 22.51 & 24.42 & 12 & 0 & 8.5 & 1.93 & -1.52 \\
\hline $3 \mathrm{H}-5,101$ & 22.61 & 24.52 & 12 & 0 & 8.9 & 1.75 & -1.32 \\
\hline $3 \mathrm{H}-5,101$ & 22.61 & 24.52 & 12 & 0 & 8.1 & 1.70 & -1.25 \\
\hline $3 \mathrm{H}-5,111$ & 22.71 & 24.62 & 12 & 0 & 8.5 & 1.90 & -1.39 \\
\hline $3 \mathrm{H}-5,111$ & 22.71 & 24.62 & 12 & 0 & 8.5 & 1.70 & -1.65 \\
\hline $3 \mathrm{H}-5,121$ & 22.81 & 24.72 & 12 & 0 & 5.9 & 1.73 & -1.62 \\
\hline $3 \mathrm{H}-5,121$ & 22.81 & 24.72 & 12 & 0 & 6.7 & 1.70 & -1.73 \\
\hline $3 \mathrm{H}-6,1$ & 23.11 & 25.02 & 12 & 0 & 7.4 & 1.97 & -1.69 \\
\hline $3 \mathrm{H}-6,1$ & 23.11 & 25.02 & 12 & 0 & 7.4 & 2.05 & -1.88 \\
\hline $3 \mathrm{H}-6,11$ & 23.21 & 25.12 & 12 & 0 & 7.0 & 1.83 & -1.31 \\
\hline $3 \mathrm{H}-6,11$ & 23.21 & 25.12 & 12 & 0 & 7.4 & 1.79 & -1.59 \\
\hline $3 \mathrm{H}-6,21$ & 23.31 & 25.22 & 12 & 0 & 7.8 & 1.69 & -1.58 \\
\hline $3 \mathrm{H}-6,21$ & 23.31 & 25.22 & 12 & 0 & 8.9 & 2.01 & -1.62 \\
\hline $3 \mathrm{H}-6,31$ & 23.41 & 25.32 & 12 & 0 & 6.7 & 1.91 & -1.86 \\
\hline $3 \mathrm{H}-6,31$ & 23.41 & 25.32 & 12 & 0 & 8.9 & 2.24 & -1.89 \\
\hline $3 \mathrm{H}-6,41$ & 23.51 & 25.42 & 12 & 0 & 6.7 & 1.95 & -1.24 \\
\hline $3 \mathrm{H}-6,41$ & 23.51 & 25.42 & 12 & 0 & 8.9 & 2.21 & -1.38 \\
\hline $3 \mathrm{H}-6,51$ & 23.61 & 25.52 & 12 & 0 & 6.7 & 1.88 & -1.77 \\
\hline $3 \mathrm{H}-6,51$ & 23.61 & 25.52 & 12 & 0 & 6.3 & 2.08 & -1.62 \\
\hline $3 \mathrm{H}-6,61$ & 23.71 & 25.62 & 12 & 0 & 5.9 & 1.75 & -1.85 \\
\hline $3 \mathrm{H}-6,61$ & 23.71 & 25.62 & 12 & 0 & 7.4 & 2.14 & -1.64 \\
\hline $3 \mathrm{H}-6,71$ & 23.81 & 25.72 & 12 & 0 & 7.0 & 1.52 & -1.29 \\
\hline $3 \mathrm{H}-6,71$ & 23.81 & 25.72 & 12 & 0 & 5.6 & 1.78 & -1.32 \\
\hline $3 \mathrm{H}-6,81$ & 23.91 & 25.82 & 12 & 0 & 7.4 & 1.64 & -1.23 \\
\hline $3 \mathrm{H}-6,81$ & 23.91 & 25.82 & 12 & 0 & 9.3 & 1.94 & -1.26 \\
\hline $3 \mathrm{H}-6,91$ & 24.01 & 25.92 & 12 & 0 & 8.1 & 1.62 & -1.37 \\
\hline $3 \mathrm{H}-6,91$ & 24.01 & 25.92 & 12 & 0 & 8.9 & 1.86 & -1.26 \\
\hline $3 \mathrm{H}-6,101$ & 24.11 & 26.02 & 12 & 0 & 8.5 & 1.38 & -1.61 \\
\hline $3 \mathrm{H}-6,101$ & 24.11 & 26.02 & 12 & 0 & 5.6 & 1.61 & -1.18 \\
\hline $3 \mathrm{H}-6,111$ & 24.21 & 26.12 & 12 & 0 & 7.8 & 1.62 & -1.43 \\
\hline $3 \mathrm{H}-6,111$ & 24.21 & 26.12 & 12 & 0 & 8.5 & 1.82 & -1.58 \\
\hline
\end{tabular}


Appendix D (continued).

\begin{tabular}{|c|c|c|c|c|c|c|c|}
\hline $\begin{array}{l}\text { Core, section, } \\
\text { interval }(\mathrm{cm})\end{array}$ & $\begin{array}{l}\text { ODP } \\
\text { depth } \\
\text { (mbsf) }\end{array}$ & $\begin{array}{l}\text { Composite } \\
\text { depth } \\
\text { (m) }\end{array}$ & $\begin{array}{l}\text { Number of } \\
\text { foraminifers } \\
\text { analyzed }\end{array}$ & $\begin{array}{l}\text { Number of } \\
\text { foraminifers } \\
\text { with sacs }\end{array}$ & $\begin{array}{l}\text { Transducer } \\
\text { pressure } \\
\text { (mbar) }\end{array}$ & $\begin{array}{l}\delta^{13} \mathrm{C} \\
\%_{0} \text { to } \\
\text { (PDB) }\end{array}$ & $\begin{array}{l}\delta^{18} \mathrm{O} \\
\%_{00} \text { to } \\
\text { (PDB) }\end{array}$ \\
\hline \multicolumn{8}{|l|}{ 121-758A-(Cont.) } \\
\hline $3 \mathrm{H}-6,121$ & 24.31 & 26.22 & 12 & 0 & 7.8 & 1.59 & -1.70 \\
\hline $3 \mathrm{H}-6,121$ & 24.31 & 26.22 & 12 & 0 & 8.5 & 1.41 & -1.51 \\
\hline $3 \mathrm{H}-6,121$ & 24.31 & 26.22 & 12 & 0 & 9.3 & 1.48 & -1.66 \\
\hline $3 \mathrm{H}-6,131$ & 24.41 & 26.32 & 12 & 0 & 5.9 & 1.36 & -1.64 \\
\hline $3 \mathrm{H}-6,131$ & 24.41 & 26.32 & 12 & 0 & 7.4 & 1.72 & -1.83 \\
\hline $3 \mathrm{H}-6,141$ & 24.51 & 26.42 & 12 & 0 & 7.4 & 1.35 & -1.62 \\
\hline $3 \mathrm{H}-7,1$ & 24.61 & 26.52 & 12 & 0 & 7.8 & 1.42 & -1.43 \\
\hline $3 \mathrm{H}-7,11$ & 24.71 & 26.62 & 12 & 0 & 7.0 & 1.06 & -1.41 \\
\hline $3 \mathrm{H}-7,21$ & 24.81 & 26.72 & 12 & 0 & 7.8 & 1.45 & -1.36 \\
\hline $3 \mathrm{H}-7,31$ & 24.91 & 26.82 & 12 & 0 & 7.4 & 1.41 & -1.41 \\
\hline $3 \mathrm{H}-7,41$ & 25.01 & 26.92 & 12 & 0 & 6.7 & 1.30 & -1.75 \\
\hline $3 \mathrm{H}-7,41$ & 25.01 & 26.92 & 12 & 0 & 8.5 & 1.61 & -1.73 \\
\hline $3 \mathrm{H}-7,51$ & 25.11 & 27.02 & 12 & 0 & 7.4 & 1.48 & -1.40 \\
\hline $3 \mathrm{H}-7,51$ & 25.11 & 27.02 & 12 & 0 & 6.3 & 1.36 & -1.38 \\
\hline $3 \mathrm{H}-7,61$ & 25.21 & 27.12 & 12 & 0 & 11.1 & 1.77 & -1.47 \\
\hline $3 \mathrm{H}-\mathrm{c}, 01$ & 25.31 & 27.22 & 12 & 0 & 11.5 & 1.86 & -1.60 \\
\hline $3 \mathrm{H}-\mathrm{c}, 11$ & 25.41 & 27.32 & 12 & 0 & 7.8 & 1.57 & -1.72 \\
\hline $4 \mathrm{H}-1,1$ & 25.21 & 29.54 & 12 & 0 & 7.0 & 1.77 & -1.59 \\
\hline $4 \mathrm{H}-1,1$ & 25.21 & 29.54 & 15 & 0 & 7.0 & 1.51 & -1.75 \\
\hline $4 \mathrm{H}-1,11$ & 25.31 & 29.64 & 12 & 0 & 6.7 & 1.57 & -1.27 \\
\hline $4 \mathrm{H}-1,11$ & 25.31 & 29.64 & 13 & 0 & 7.8 & 1.66 & -1.52 \\
\hline $4 \mathrm{H}-1,21$ & 25.41 & 29.74 & 12 & 0 & 7.8 & 1.10 & -1.48 \\
\hline $4 \mathrm{H}-1,31$ & 25.51 & 29.84 & 12 & 0 & 10.4 & 1.93 & -1.52 \\
\hline $4 \mathrm{H}-1,41$ & 25.61 & 29.94 & 12 & 0 & 8.1 & 1.70 & -1.50 \\
\hline $4 \mathrm{H}-1,51$ & 25.71 & 30.04 & 12 & 0 & 5.6 & 1.47 & -1.32 \\
\hline $4 \mathrm{H}-1,61$ & 25.81 & 30.14 & 12 & 0 & 6.3 & 1.54 & -1.33 \\
\hline $4 \mathrm{H}-1,71$ & 25.91 & 30.24 & 12 & 0 & 7.8 & 1.82 & -1.83 \\
\hline $4 \mathrm{H}-1,71$ & 25.91 & 30.24 & 13 & 0 & 7.8 & 1.71 & -1.87 \\
\hline $4 \mathrm{H}-1,81$ & 26.01 & 30.34 & 12 & 0 & 6.7 & 1.23 & -1.52 \\
\hline $4 \mathrm{H}-1,81$ & 26.01 & 30.34 & 12 & 0 & 5.9 & 1.51 & -1.41 \\
\hline $4 \mathrm{H}-1,91$ & 26.11 & 30.44 & 12 & 0 & 7.8 & 1.71 & -1.54 \\
\hline $4 \mathrm{H}-1,91$ & 26.11 & 30.44 & 12 & 0 & 7.4 & 1.54 & -1.44 \\
\hline $4 \mathrm{H}-1,101$ & 26.21 & 30.54 & 12 & 0 & 5.2 & 1.82 & -1.80 \\
\hline $4 \mathrm{H}-1,101$ & 26.21 & 30.54 & 12 & 0 & 6.3 & 1.49 & -1.96 \\
\hline $4 \mathrm{H}-1,111$ & 26.31 & 30.64 & 12 & 0 & 6.3 & 1.46 & -1.40 \\
\hline $4 \mathrm{H}-1,121$ & 26.41 & 30.74 & 12 & 0 & 5.9 & 1.46 & -1.61 \\
\hline $4 \mathrm{H}-1,121$ & 26.41 & 30.74 & 12 & 0 & 6.3 & 1.73 & -1.49 \\
\hline $4 \mathrm{H}-1,131$ & 26.51 & 30.84 & 12 & 0 & 6.3 & 1.82 & -1.50 \\
\hline $4 \mathrm{H}-1,131$ & 26.51 & 30.84 & 13 & 0 & 8.5 & 2.20 & -1.38 \\
\hline $4 \mathrm{H}-1,141$ & 26.61 & 30.94 & 12 & 0 & 6.7 & 1.87 & -1.96 \\
\hline $4 \mathrm{H}-1,141$ & 26.61 & 30.94 & 13 & 0 & 7.8 & 1.97 & -1.89 \\
\hline $4 \mathrm{H}-2,1$ & 26.71 & 31.04 & 12 & 0 & 8.1 & 1.87 & -1.76 \\
\hline $4 \mathrm{H}-2,1$ & 26.71 & 31.04 & 12 & 0 & 6.3 & 1.74 & -1.60 \\
\hline $4 \mathrm{H}-2,11$ & 26.81 & 31.14 & 12 & 0 & 9.6 & 1.90 & -1.81 \\
\hline $4 \mathrm{H}-2,11$ & 26.81 & 31.14 & 12 & 0 & 8.5 & 1.79 & -1.49 \\
\hline $4 \mathrm{H}-2,21$ & 26.91 & 31.24 & 12 & 0 & 6.7 & 1.81 & -1.61 \\
\hline $4 \mathrm{H}-2,21$ & 26.91 & 31.24 & 12 & 0 & 7.4 & 1.80 & -1.66 \\
\hline $4 \mathrm{H}-2,31$ & 27.01 & 31.34 & 12 & 0 & 6.3 & 1.57 & -1.27 \\
\hline $4 \mathrm{H}-2,31$ & 27.01 & 31.34 & 12 & 0 & 8.5 & 1.87 & -1.46 \\
\hline $4 \mathrm{H}-2,41$ & 27.11 & 31.44 & 12 & 0 & 7.4 & 1.65 & -1.46 \\
\hline $4 \mathrm{H}-2,41$ & 27.11 & 31.44 & 12 & 0 & 6.7 & 1.45 & -1.39 \\
\hline $4 \mathrm{H}-2,51$ & 27.21 & 31.54 & 12 & 0 & 5.2 & 1.23 & -1.11 \\
\hline $4 \mathrm{H}-2,51$ & 27.21 & 31.54 & 12 & 0 & 6.7 & 1.57 & -1.12 \\
\hline $4 \mathrm{H}-2,61$ & 27.31 & 31.64 & 12 & 0 & 7.8 & 1.54 & -1.51 \\
\hline $4 \mathrm{H}-2,61$ & 27.31 & 31.64 & 12 & 0 & 8.5 & 1.65 & -1.44 \\
\hline $4 \mathrm{H}-2,71$ & 27.41 & 31.74 & 12 & 0 & 7.0 & 1.68 & -1.24 \\
\hline $4 \mathrm{H}-2,71$ & 27.41 & 31.74 & 12 & 0 & 7.0 & 1.63 & -1.39 \\
\hline $4 \mathrm{H}-2,81$ & 27.51 & 31.84 & 12 & 0 & 7.8 & 1.70 & -1.65 \\
\hline $4 \mathrm{H}-2,81$ & 27.51 & 31.84 & 14 & 0 & 7.0 & 1.45 & -1.32 \\
\hline $4 \mathrm{H}-2,91$ & 27.61 & 31.94 & 12 & 0 & 7.4 & 1.72 & -1.52 \\
\hline $4 \mathrm{H}-2,91$ & 27.61 & 31.94 & 12 & 0 & 7.4 & 1.89 & -1.54 \\
\hline $4 \mathrm{H}-2,101$ & 27.71 & 32.04 & 12 & 0 & 6.3 & 1.67 & -1.67 \\
\hline $4 \mathrm{H}-2,101$ & 27.71 & 32.04 & 12 & 0 & 6.7 & 1.53 & -1.39 \\
\hline $4 \mathrm{H}-2,111$ & 27.81 & 32.14 & 10 & 0 & 5.2 & 1.62 & -1.63 \\
\hline $4 \mathrm{H}-2,111$ & 27.81 & 32.14 & 10 & 10 & 5.2 & 1.67 & -1.53 \\
\hline $4 \mathrm{H}-2,121$ & 27.91 & 32.24 & 12 & 0 & 6.7 & 1.67 & -1.38 \\
\hline $4 \mathrm{H}-2,121$ & 27.91 & 32.24 & 12 & 0 & 5.9 & 1.61 & -1.39 \\
\hline $4 \mathrm{H}-2,131$ & 28.01 & 32.34 & 12 & 0 & 6.3 & 1.65 & -1.29 \\
\hline $4 \mathrm{H}-2,131$ & 28.01 & 32.34 & 12 & 0 & 8.5 & 1.66 & -1.16 \\
\hline $4 \mathrm{H}-2,141$ & 28.11 & 32.44 & 12 & 0 & 7.0 & 1.47 & -1.64 \\
\hline $4 \mathrm{H}-2,141$ & 28.11 & 32.44 & 12 & 0 & 7.8 & 1.59 & -1.68 \\
\hline $4 \mathrm{H}-3,1$ & 28.21 & 32.54 & 12 & 0 & 8.1 & 1.46 & -0.96 \\
\hline $4 \mathrm{H}-3,1$ & 28.21 & 32.54 & 12 & 0 & 8.5 & 1.65 & -1.02 \\
\hline $4 \mathrm{H}-3,11$ & 28.31 & 32.64 & 12 & 0 & 7.4 & 1.57 & -1.19 \\
\hline $4 \mathrm{H}-3,21$ & 28.41 & 32.74 & 12 & 0 & 8.1 & 1.71 & -1.11 \\
\hline $4 \mathrm{H}-3,21$ & 28.41 & 32.74 & 12 & 0 & 6.3 & 1.28 & -1.35 \\
\hline
\end{tabular}


Appendix D (continued).

\begin{tabular}{|c|c|c|c|c|c|c|c|}
\hline $\begin{array}{l}\text { Core, section, } \\
\text { interval }(\mathrm{cm})\end{array}$ & $\begin{array}{l}\text { ODP } \\
\text { depth } \\
\text { (mbsf) }\end{array}$ & $\begin{array}{l}\text { Composite } \\
\text { depth } \\
\text { (m) }\end{array}$ & $\begin{array}{l}\text { Number of } \\
\text { foraminifers } \\
\text { analyzed }\end{array}$ & $\begin{array}{l}\text { Number of } \\
\text { foraminifers } \\
\text { with sacs }\end{array}$ & $\begin{array}{l}\text { Transducer } \\
\text { pressure } \\
\text { (mbar) }\end{array}$ & $\begin{array}{l}\delta^{13} \mathrm{C} \\
\%_{0} \text { to } \\
\text { (PDB) }\end{array}$ & $\begin{array}{l}\delta^{18} \mathrm{O} \\
\%_{0} \text { to } \\
\text { (PDB) }\end{array}$ \\
\hline \multicolumn{8}{|l|}{ 121-758A-(Cont.) } \\
\hline $4 \mathrm{H}-3,31$ & 28.51 & 32.84 & 12 & 0 & 0.4 & 1.46 & -1.44 \\
\hline $4 \mathrm{H}-3,31$ & 28.51 & 32.84 & 14 & 0 & 6.7 & 1.86 & -1.28 \\
\hline $4 \mathrm{H}-3,41$ & 28.61 & 32.94 & 12 & 0 & 7.8 & 1.86 & -1.35 \\
\hline $4 \mathrm{H}-3,41$ & 28.61 & 32.94 & 13 & 0 & 7.8 & 1.74 & -1.56 \\
\hline $4 \mathrm{H}-3,51$ & 28.71 & 33.04 & 12 & 0 & 6.7 & 1.71 & -1.79 \\
\hline $4 \mathrm{H}-3,51$ & 28.71 & 33.04 & 12 & 0 & 6.7 & 1.74 & -1.38 \\
\hline $4 \mathrm{H}-3,61$ & 28.81 & 33.14 & 12 & 0 & 7.4 & 1.67 & -1.93 \\
\hline $4 \mathrm{H}-3,61$ & 28.81 & 33.14 & 12 & 0 & 6.3 & 1.80 & -1.87 \\
\hline $4 \mathrm{H}-3,71$ & 28.91 & 33.24 & 12 & 0 & 9.3 & 1.91 & -2.17 \\
\hline $4 \mathrm{H}-3,71$ & 28.91 & 33.24 & 12 & 0 & 8.1 & 1.83 & -2.25 \\
\hline $4 \mathrm{H}-3,81$ & 29.01 & 33.34 & 12 & 0 & 6.7 & 1.62 & -1.40 \\
\hline $4 \mathrm{H}-3,81$ & 29.01 & 33.34 & 12 & 0 & 8.5 & 1.76 & -1.38 \\
\hline $4 \mathrm{H}-3,91$ & 29.11 & 33.44 & 12 & 0 & 7.8 & 1.74 & -1.48 \\
\hline $4 \mathrm{H}-3,91$ & 29.11 & 33.44 & 12 & 0 & 8.5 & 1.79 & -1.36 \\
\hline $4 \mathrm{H}-3,101$ & 29.21 & 33.54 & 12 & 0 & 7.8 & 1.66 & -1.56 \\
\hline $4 \mathrm{H}-3,101$ & 29.21 & 33.54 & 12 & 0 & 6.3 & 1.71 & -1.49 \\
\hline $4 \mathrm{H}-3,111$ & 29.31 & 33.64 & 12 & 0 & 7.4 & 1.66 & -1.86 \\
\hline $4 \mathrm{H}-3,111$ & 29.31 & 33.64 & 15 & 0 & 11.1 & 1.55 & -2.09 \\
\hline $4 \mathrm{H}-3,121$ & 29.41 & 33.74 & 12 & 0 & 8.1 & 1.84 & -1.68 \\
\hline $4 \mathrm{H}-3,121$ & 29.41 & 33.74 & 12 & 0 & 8.5 & 1.79 & -1.56 \\
\hline $4 \mathrm{H}-3,131$ & 29.51 & 33.84 & 12 & 0 & 7.4 & 1.52 & -1.62 \\
\hline $4 \mathrm{H}-3,131$ & 29.51 & 33.84 & 12 & 0 & 7.4 & 1.66 & -1.72 \\
\hline $4 \mathrm{H}-3,141$ & 29.61 & 33.94 & 12 & 0 & 7.8 & 1.69 & -1.54 \\
\hline $4 \mathrm{H}-3,141$ & 29.61 & 33.94 & 12 & 0 & 7.4 & 0.95 & -1.31 \\
\hline $4 \mathrm{H}-4,1$ & 29.71 & 34.04 & 12 & 0 & 5.6 & 1.62 & -1.17 \\
\hline $4 \mathrm{H}-4,1$ & 29.71 & 34.04 & 13 & 0 & 9.6 & 1.58 & -1.46 \\
\hline $4 \mathrm{H}-4,11$ & 29.81 & 34.14 & 12 & 0 & 7.0 & 1.83 & -2.16 \\
\hline $4 \mathrm{H}-4,11$ & 29.81 & 34.14 & 14 & 3 & 8.5 & 2.06 & -2.13 \\
\hline $4 \mathrm{H}-4,21$ & 29.91 & 34.24 & 12 & 0 & 7.8 & 1.76 & -1.63 \\
\hline $4 \mathrm{H}-4,21$ & 29.91 & 34.24 & 13 & 0 & 7.8 & 1.86 & -1.86 \\
\hline $4 \mathrm{H}-4,31$ & 30.01 & 34.34 & 12 & 0 & 6.3 & 1.46 & -1.78 \\
\hline $4 \mathrm{H}-4,31$ & 30.01 & 34.34 & 13 & 0 & 8.1 & 1.63 & -1.86 \\
\hline $4 \mathrm{H}-4,41$ & 30.11 & 34.44 & 12 & 0 & 8.1 & 1.60 & -1.31 \\
\hline $4 \mathrm{H}-4,41$ & 30.11 & 34.44 & 15 & 0 & 11.1 & 1.54 & -1.87 \\
\hline $4 \mathrm{H}-4,41$ & 30.11 & 34.44 & 11 & 0 & 9.3 & 1.61 & -1.54 \\
\hline $4 \mathrm{H}-4,51$ & 30.21 & 34.54 & 12 & 0 & 7.0 & 1.78 & -1.47 \\
\hline $4 \mathrm{H}-4,51$ & 30.21 & 34.54 & 15 & 0 & 7.8 & 1.50 & -1.61 \\
\hline $4 \mathrm{H}-4,61$ & 30.31 & 34.64 & 12 & 0 & 8.1 & 1.87 & -1.57 \\
\hline $4 \mathrm{H}-4,61$ & 30.31 & 34.64 & 13 & 0 & 8.1 & 1.64 & -1.77 \\
\hline $4 \mathrm{H}-4,71$ & 30.41 & 34.74 & 12 & 0 & 7.4 & 1.51 & -1.81 \\
\hline $4 \mathrm{H}-4,71$ & 30.41 & 34.74 & 12 & 0 & 7.8 & 1.57 & -1.78 \\
\hline $4 \mathrm{H}-4,81$ & 30.51 & 34.84 & 12 & 0 & 10.0 & 1.82 & -1.69 \\
\hline $4 \mathrm{H}-4,81$ & 30.51 & 34.84 & 13 & 0 & 4.1 & 1.75 & -1.63 \\
\hline $4 \mathrm{H}-4,91$ & 30.61 & 34.94 & 12 & 0 & 8.5 & 1.55 & -1.77 \\
\hline $4 \mathrm{H}-4,91$ & 30.61 & 34.94 & 12 & 0 & 8.5 & 1.52 & -1.41 \\
\hline $4 \mathrm{H}-4,91$ & 30.61 & 34.94 & 13 & 0 & 9.3 & 1.60 & -1.89 \\
\hline $4 \mathrm{H}-4,91$ & 30.61 & 34.94 & 7 & 7 & 11.1 & 1.61 & -1.69 \\
\hline $4 \mathrm{H}-4,101$ & 30.71 & 35.04 & 12 & 0 & 8.1 & 1.51 & -1.63 \\
\hline $4 \mathrm{H}-4,101$ & 30.71 & 35.04 & 15 & 0 & 10.0 & 1.65 & -1.69 \\
\hline $4 \mathrm{H}-4,111$ & 30.81 & 35.14 & 15 & 0 & 9.3 & 1.75 & -1.90 \\
\hline $4 \mathrm{H}-4,111$ & 30.81 & 35.14 & 12 & 0 & 6.3 & 1.64 & -1.86 \\
\hline $4 \mathrm{H}-4,121$ & 30.91 & 35.24 & 12 & 0 & 6.3 & 1.41 & -1.52 \\
\hline $4 \mathrm{H}-4,121$ & 30.91 & 35.24 & 13 & 0 & 8.1 & 1.81 & -1.49 \\
\hline $4 \mathrm{H}-4,12 \mathrm{I}$ & 30.91 & 35.24 & 12 & 0 & 7.0 & 1.59 & -1.58 \\
\hline $4 \mathrm{H}-4,131$ & 31.01 & 35.34 & 12 & 0 & 9.6 & 1.69 & -1.25 \\
\hline $4 \mathrm{H}-4,131$ & 31.01 & 35.34 & 12 & 0 & 15.6 & 1.56 & -1.25 \\
\hline $4 \mathrm{H}-4,131$ & 31.01 & 35.34 & 15 & 0 & 8.9 & 1.65 & -1.35 \\
\hline $4 \mathrm{H}-4,141$ & 31.11 & 35.44 & 12 & 0 & 5.9 & 1.76 & -1.31 \\
\hline $4 \mathrm{H}-5,7$ & 31.27 & 35.60 & 12 & 0 & 8.5 & 1.91 & -1.36 \\
\hline $4 \mathrm{H}-5,7$ & 31.27 & 35.60 & 13 & 0 & 10.0 & 1.76 & -1.73 \\
\hline $4 \mathrm{H}-5,7$ & 31.27 & 35.60 & 12 & 0 & 7.0 & 1.87 & -1.60 \\
\hline $4 \mathrm{H}-5,11$ & 31.31 & 35.64 & 15 & 0 & 9.3 & 1.80 & -2.03 \\
\hline $4 \mathrm{H}-5,11$ & 31.31 & 35.64 & 11 & 0 & 5.9 & 1.89 & -1.39 \\
\hline $4 \mathrm{H}-5,21$ & 31.41 & 35.74 & 14 & 0 & 8.1 & 1.62 & -1.84 \\
\hline $4 \mathrm{H}-5,21$ & 31.41 & 35.74 & 12 & 0 & 5.9 & 2.03 & -1.84 \\
\hline $4 \mathrm{H}-5,31$ & 31.51 & 35.84 & 15 & 0 & 11.5 & 2.13 & -1.66 \\
\hline $4 \mathrm{H}-5,31$ & 31.51 & 35.84 & 12 & 0 & 7.0 & 1.70 & -1.78 \\
\hline $4 \mathrm{H}-5,41$ & 31.61 & 35.94 & 12 & 0 & 8.1 & 2.21 & -1.46 \\
\hline $4 \mathrm{H}-5,41$ & 31.61 & 35.94 & 15 & 0 & 10.0 & 2.15 & -1.75 \\
\hline $4 \mathrm{H}-5,51$ & 31.71 & 36.04 & 12 & 0 & 8.1 & 1.94 & -1.43 \\
\hline $4 \mathrm{H}-5,51$ & 31.71 & 36.04 & 13 & 0 & 8.5 & 1.94 & -1.57 \\
\hline $4 \mathrm{H}-5,61$ & 31.81 & 36.14 & 15 & 0 & 12.2 & 1.70 & -1.80 \\
\hline $4 \mathrm{H}-5,61$ & 31.81 & 36.14 & 13 & 0 & 8.9 & 1.97 & -1.87 \\
\hline $4 \mathrm{H}-5,71$ & 31.91 & 36.24 & 12 & 0 & 10.4 & 1.78 & -1.56 \\
\hline $4 \mathrm{H}-5,71$ & 31.91 & 36.24 & 12 & 0 & 7.8 & 1.80 & -1.67 \\
\hline $4 \mathrm{H}-5,81$ & 32.01 & 36.34 & 12 & 0 & 8.1 & 1.66 & -1.42 \\
\hline
\end{tabular}


Appendix D (continued).

\begin{tabular}{|c|c|c|c|c|c|c|c|}
\hline $\begin{array}{l}\text { Core, section, } \\
\text { interval }(\mathrm{cm})\end{array}$ & $\begin{array}{l}\text { ODP } \\
\text { depth } \\
\text { (mbsf) }\end{array}$ & $\begin{array}{l}\text { Composite } \\
\text { depth } \\
\text { (m) }\end{array}$ & $\begin{array}{l}\text { Number of } \\
\text { foraminifers } \\
\text { analyzed }\end{array}$ & $\begin{array}{l}\text { Number of } \\
\text { foraminifers } \\
\text { with sacs }\end{array}$ & $\begin{array}{l}\text { Transducer } \\
\text { pressure } \\
\text { (mbar) }\end{array}$ & $\begin{array}{l}\delta^{13} \mathrm{C} \\
\% 00 \text { to } \\
\text { (PDB) }\end{array}$ & $\begin{array}{l}\delta^{18} \mathrm{O} \\
\%_{00} \text { to } \\
\text { (PDB) }\end{array}$ \\
\hline \multicolumn{8}{|l|}{ 121-758A-(Cont.) } \\
\hline $4 \mathrm{H}-5,81$ & 32.01 & 36.34 & 15 & 0 & 8.9 & 1.60 & -1.52 \\
\hline $4 \mathrm{H}-5,91$ & 32.11 & 36.44 & 12 & 0 & 6.3 & 1.81 & -1.30 \\
\hline $4 \mathrm{H}-5,91$ & 32.11 & 36.44 & 15 & 0 & 12.6 & 1.69 & -1.49 \\
\hline $4 \mathrm{H}-5,101$ & 32.21 & 36.54 & 12 & 0 & 7.4 & 1.69 & -1.47 \\
\hline $4 \mathrm{H}-5,101$ & 32.21 & 36.54 & 14 & 0 & 9.6 & 1.53 & -1.52 \\
\hline $4 \mathrm{H}-5,111$ & 32.31 & 36.64 & 12 & 0 & 6.3 & 1.55 & -1.36 \\
\hline $4 \mathrm{H}-5,111$ & 32.31 & 36.64 & 15 & 0 & 7.0 & 1.53 & -1.61 \\
\hline $4 \mathrm{H}-5,121$ & 32.41 & 36.74 & 12 & 0 & 7.0 & 1.67 & -1.51 \\
\hline $4 \mathrm{H}-5,121$ & 32.41 & 36.74 & 12 & 0 & 7.4 & 1.77 & -1.72 \\
\hline $4 \mathrm{H}-5,131$ & 32.51 & 36.84 & 12 & 0 & 8.5 & 1.75 & -1.79 \\
\hline $4 \mathrm{H}-5,131$ & 32.51 & 36.84 & 12 & 0 & 8.1 & 1.89 & -1.90 \\
\hline $4 \mathrm{H}-5,141$ & 32.61 & 36.94 & 12 & 0 & 7.4 & 1.70 & -1.83 \\
\hline $4 \mathrm{H}-5,141$ & 32.61 & 36.94 & 12 & 0 & 9.3 & 1.55 & -2.05 \\
\hline $4 \mathrm{H}-6,1$ & 32.71 & 37.04 & 12 & 0 & 9.6 & 1.47 & -1.56 \\
\hline $4 \mathrm{H}-6,1$ & 32.71 & 37.04 & 12 & 0 & 7.4 & 1.33 & -1.66 \\
\hline $4 \mathrm{H}-6,11$ & 32.81 & 37.14 & 12 & 0 & 8.9 & 1.57 & -1.09 \\
\hline $4 \mathrm{H}-6,11$ & 32.81 & 37.14 & 12 & 0 & 8.5 & 1.45 & -0.90 \\
\hline $4 \mathrm{H}-6,11$ & 32.81 & 37.14 & 12 & 0 & 7.4 & 1.62 & -1.10 \\
\hline $4 \mathrm{H}-6,21$ & 32.91 & 37.24 & 12 & 0 & 6.7 & 1.52 & -1.17 \\
\hline $4 \mathrm{H}-6,21$ & 32.91 & 37.24 & 12 & 0 & 10.0 & 1.81 & -1.70 \\
\hline $4 \mathrm{H}-6,21$ & 32.91 & 37.24 & 15 & 0 & 9.3 & 1.42 & -1.60 \\
\hline $4 \mathrm{H}-6,31$ & 33.01 & 37.34 & 12 & 0 & 7.4 & 1.51 & -1.82 \\
\hline $4 \mathrm{H}-6,31$ & 33.01 & 37.34 & 12 & 0 & 5.6 & 1.96 & -1.93 \\
\hline $4 \mathrm{H}-6,41$ & 33.11 & 37.44 & 12 & 0 & 7.8 & 1.28 & -1.26 \\
\hline $4 \mathrm{H}-6,41$ & 33.11 & 37.44 & 12 & 0 & 8.1 & 1.33 & -1.53 \\
\hline $4 \mathrm{H}-6,51$ & 33.21 & 37.54 & 12 & 0 & 7.8 & 1.24 & -1.13 \\
\hline $4 \mathrm{H}-6,51$ & 33.21 & 37.54 & 12 & 0 & 8.5 & 1.29 & -1.20 \\
\hline $4 \mathrm{H}-6,61$ & 33.31 & 37.64 & 12 & 0 & 9.6 & 1.32 & -1.51 \\
\hline $4 \mathrm{H}-6,61$ & 33.31 & 37.64 & 12 & 0 & 9.3 & 1.45 & -1.41 \\
\hline $4 \mathrm{H}-6,71$ & 33.41 & 37.74 & 12 & 0 & 6.7 & 1.27 & -1.13 \\
\hline $4 \mathrm{H}-6,71$ & 33.41 & 37.74 & 12 & 0 & 9.3 & 1.42 & -1.38 \\
\hline $4 \mathrm{H}-6,81$ & 33.51 & 37.84 & 12 & 0 & 7.8 & 1.25 & -2.19 \\
\hline $4 \mathrm{H}-6,81$ & 33.51 & 37.84 & 15 & 0 & 9.3 & 1.35 & -1.54 \\
\hline $4 \mathrm{H}-6,91$ & 33.61 & 37.94 & 12 & 0 & 6.3 & 1.73 & -1.76 \\
\hline $4 \mathrm{H}-6,91$ & 33.61 & 37.94 & 12 & 0 & 0.4 & 1.77 & -1.72 \\
\hline $4 \mathrm{H}-6,101$ & 33.71 & 38.04 & 12 & 0 & 7.0 & 1.75 & -1.39 \\
\hline $4 \mathrm{H}-6,101$ & 33.71 & 38.04 & 13 & 2 & 7.4 & 1.63 & -1.79 \\
\hline $4 \mathrm{H}-6,111$ & 33.81 & 38.14 & 12 & 0 & 6.3 & 1.50 & -1.59 \\
\hline $4 \mathrm{H}-6,111$ & 33.81 & 38.14 & 12 & 0 & 5.9 & 1.40 & -1.71 \\
\hline $4 \mathrm{H}-6,121$ & 33.91 & 38.24 & 12 & 0 & 7.4 & 1.84 & -1.79 \\
\hline $4 \mathrm{H}-6,121$ & 33.91 & 38.24 & 12 & 0 & 7.4 & 1.63 & -1.94 \\
\hline $4 \mathrm{H}-6,131$ & 34.01 & 38.34 & 12 & 0 & 6.7 & 1.67 & -1.68 \\
\hline $4 \mathrm{H}-6,131$ & 34.01 & 38.34 & 12 & 0 & 6.3 & 1.49 & -1.66 \\
\hline $4 \mathrm{H}-6,141$ & 34.11 & 38.44 & 12 & 0 & 8.5 & 1.71 & -2.21 \\
\hline $4 \mathrm{H}-6,141$ & 34.11 & 38.44 & 12 & 0 & 6.7 & 1.75 & -2.12 \\
\hline $4 \mathrm{H}-7,1$ & 34.21 & 38.54 & 12 & 0 & 7.8 & 1.30 & -1.75 \\
\hline $4 \mathrm{H}-7,1$ & 34.21 & 38.54 & 12 & 0 & 7.4 & 1.36 & -1.65 \\
\hline $4 \mathrm{H}-7,11$ & 34.31 & 38.64 & 12 & 0 & 7.8 & 1.49 & -1.43 \\
\hline $4 \mathrm{H}-7,11$ & 34.31 & 38.64 & 12 & 0 & 7.4 & 1.42 & -1.56 \\
\hline $4 \mathrm{H}-7,21$ & 34.41 & 38.74 & 12 & 0 & 8.1 & 1.55 & -1.35 \\
\hline $4 \mathrm{H}-7,21$ & 34.41 & 38.74 & 12 & 0 & 8.1 & 1.42 & -1.31 \\
\hline $4 \mathrm{H}-7,31$ & 34.51 & 38.84 & 12 & 0 & 6.3 & 1.76 & -1.83 \\
\hline $4 \mathrm{H}-7,31$ & 34.51 & 38.84 & 12 & 0 & 7.0 & 1.81 & -1.54 \\
\hline $4 \mathrm{H}-7,41$ & 34.61 & 38.94 & 12 & 0 & 6.7 & 1.75 & -1.66 \\
\hline $4 \mathrm{H}-7,41$ & 34.61 & 38.94 & 12 & 0 & 5.9 & 1.39 & -1.43 \\
\hline $4 \mathrm{H}-7,51$ & 34.71 & 39.04 & 12 & 0 & 4.8 & 1.52 & -2.03 \\
\hline $4 \mathrm{H}-7,51$ & 34.71 & 39.04 & 12 & 0 & 6.7 & 1.67 & -1.92 \\
\hline
\end{tabular}


APPENDIX E

$\delta^{13} \mathrm{C}$ and $\delta^{18} \mathrm{O}$ Data, G. sacculifera $(300-355 \mu \mathrm{m})$, Hole 758B

\begin{tabular}{|c|c|c|c|c|c|c|c|}
\hline $\begin{array}{l}\text { Core, section, } \\
\text { interval }(\mathrm{cm})\end{array}$ & $\begin{array}{l}\text { ODP } \\
\text { depth } \\
\text { (mbsf) }\end{array}$ & $\begin{array}{l}\text { Composite } \\
\text { depth } \\
\text { (m) }\end{array}$ & $\begin{array}{l}\text { Number of } \\
\text { foraminifers } \\
\text { analyzed }\end{array}$ & $\begin{array}{l}\text { Number of } \\
\text { foraminifers } \\
\text { with sacs }\end{array}$ & $\begin{array}{l}\text { Transducer } \\
\text { pressure } \\
\text { (mbar) }\end{array}$ & $\begin{array}{l}\delta^{13} \mathrm{C} \\
\%_{0} \text { to } \\
\text { (PDB) }\end{array}$ & $\begin{array}{l}\delta^{18} \mathrm{O} \\
\%_{0} \text { to } \\
\text { (PDB) }\end{array}$ \\
\hline \multicolumn{8}{|l|}{$121-758 \mathrm{~B}-$} \\
\hline $1 \mathrm{H}-3,61$ & 3.61 & 5.12 & 15 & 0 & 8.5 & 1.39 & -1.10 \\
\hline $1 \mathrm{H}-3,61$ & 3.61 & 5.12 & 13 & 0 & 7.0 & 1.20 & -0.80 \\
\hline $1 \mathrm{H}-3,71$ & 3.71 & 5.22 & 15 & 0 & 9.3 & 1.26 & -0.74 \\
\hline $1 \mathrm{H}-3,81$ & 3.81 & 5.32 & 15 & 0 & 8.5 & 1.56 & -0.44 \\
\hline $1 \mathrm{H}-3,81$ & 3.81 & 5.32 & 15 & 0 & 7.8 & 1.41 & -0.83 \\
\hline $1 \mathrm{H}-3,91$ & 3.91 & 5.42 & 9 & 0 & 4.4 & 1.65 & -0.93 \\
\hline $1 \mathrm{H}-3,101$ & 4.01 & 5.52 & 15 & 0 & 7.8 & 1.57 & -1.27 \\
\hline $1 \mathrm{H}-3,101$ & 4.01 & 5.52 & 13 & 0 & 5.9 & 1.53 & -1.30 \\
\hline $1 \mathrm{H}-3,111$ & 4.11 & 5.62 & 15 & 0 & 5.9 & 1.46 & -0.94 \\
\hline $1 \mathrm{H}-3,121$ & 4.21 & 5.72 & 15 & 0 & 7.4 & 1.61 & -0.99 \\
\hline $1 \mathrm{H}-3,121$ & 4.21 & 5.72 & 15 & 0 & 8.1 & 1.60 & -1.24 \\
\hline $1 \mathrm{H}-3,131$ & 4.31 & 5.82 & 15 & 0 & 9.3 & 1.66 & -1.10 \\
\hline $1 \mathrm{H}-3,131$ & 4.31 & 5.82 & 12 & 0 & 6.7 & 1.36 & -1.26 \\
\hline $1 \mathrm{H}-3,141$ & 4.41 & 5.92 & 13 & 0 & 7.8 & 1.49 & -1.54 \\
\hline $1 \mathrm{H}-3,141$ & 4.41 & 5.92 & 13 & 0 & 5.6 & 1.50 & -1.43 \\
\hline $1 \mathrm{H}-4,1$ & 4.51 & 6.02 & 9 & 0 & 3.0 & 1.29 & -1.57 \\
\hline $1 \mathrm{H}-4,11$ & 4.61 & 6.12 & 10 & 0 & 2.6 & 1.19 & -1.68 \\
\hline $1 \mathrm{H}-4,21$ & 4.71 & 6.22 & 11 & 0 & 3.3 & 1.28 & -1.70 \\
\hline $1 \mathrm{H}-4,31$ & 4.81 & 6.32 & 12 & 0 & 4.8 & 1.12 & -1.69 \\
\hline $1 \mathrm{H}-4,31$ & 4.81 & 6.32 & 12 & 0 & 5.6 & 0.97 & -1.76 \\
\hline $1 \mathrm{H}-4,41$ & 4.91 & 6.42 & 15 & 0 & 7.4 & 0.99 & -1.50 \\
\hline $1 \mathrm{H}-4,51$ & 5.01 & 6.52 & 13 & 0 & 7.4 & 1.06 & -0.93 \\
\hline $1 \mathrm{H}-4,61$ & 5.11 & 6.62 & 10 & 0 & 6.3 & 1.41 & -0.46 \\
\hline $1 \mathrm{H}-4,61$ & 5.11 & 6.62 & 9 & 0 & 5.9 & 1.26 & -0.52 \\
\hline $1 \mathrm{H}-4,71$ & 5.21 & 6.72 & 13 & 0 & 7.4 & 1.32 & -0.80 \\
\hline $1 \mathrm{H}-4,71$ & 5.21 & 6.72 & 12 & 0 & 5.9 & 1.49 & -0.74 \\
\hline $1 \mathrm{H}-4,81$ & 5.31 & 6.82 & 15 & 0 & 7.4 & 1.47 & -0.67 \\
\hline $1 \mathrm{H}-4,81$ & 5.31 & 6.82 & 12 & 0 & 6.3 & 1.44 & -0.95 \\
\hline $1 \mathrm{H}-4,81$ & 5.31 & 6.82 & 12 & 0 & 5.6 & 1.00 & -0.84 \\
\hline $1 \mathrm{H}-4,91$ & 5.41 & 6.92 & 15 & 0 & 5.9 & 1.50 & -0.68 \\
\hline $1 \mathrm{H}-4,91$ & 5.41 & 6.92 & 12 & 0 & 6.3 & 1.47 & -0.89 \\
\hline $1 \mathrm{H}-4,101$ & 5.51 & 7.02 & 12 & 0 & 5.2 & 1.43 & -1.17 \\
\hline $1 \mathrm{H}-4,111$ & 5.61 & 7.12 & 15 & 0 & 7.8 & 1.52 & -1.52 \\
\hline $1 \mathrm{H}-4,121$ & 5.71 & 7.22 & 13 & 0 & 5.9 & 1.49 & -1.64 \\
\hline $1 \mathrm{H}-4,121$ & 5.71 & 7.22 & 12 & 0 & 6.3 & 1.41 & -1.44 \\
\hline $1 \mathrm{H}-4,141$ & 5.91 & 7.42 & 6 & 0 & 2.6 & 1.85 & -1.87 \\
\hline $1 \mathrm{H}-4,141$ & 5.91 & 7.42 & 9 & 4 & 6.7 & 1.78 & -1.75 \\
\hline $1 \mathrm{H}-5,1$ & 6.01 & 7.52 & 15 & 0 & 6.3 & 1.27 & -1.15 \\
\hline $1 \mathrm{H}-5,1$ & 6.01 & 7.52 & 12 & 0 & 4.8 & 1.27 & -1.10 \\
\hline $1 \mathrm{H}-5,11$ & 6.11 & 7.62 & 15 & 0 & 9.3 & 1.40 & -0.64 \\
\hline $1 \mathrm{H}-5,21$ & 6.21 & 7.72 & 15 & 0 & 8.9 & 1.55 & -0.34 \\
\hline $1 \mathrm{H}-5,31$ & 6.31 & 7.82 & 13 & 0 & 5.9 & 1.51 & -0.64 \\
\hline $1 \mathrm{H}-5,41$ & 6.41 & 7.92 & 13 & 0 & 8.1 & 1.77 & -0.97 \\
\hline $1 \mathrm{H}-5,51$ & 6.51 & 8.02 & 13 & 0 & 8.1 & 1.65 & -0.98 \\
\hline $1 \mathrm{H}-5,61$ & 6.61 & 8.12 & 13 & 0 & 7.0 & 1.80 & -0.84 \\
\hline $1 \mathrm{H}-5,61$ & 6.61 & 8.12 & 12 & 0 & 6.7 & 1.51 & -0.88 \\
\hline $2 \mathrm{H}-5,1$ & 15.51 & 17.01 & 12 & 0 & 5.6 & 1.43 & -1.52 \\
\hline $2 \mathrm{H}-5,11$ & 15.61 & 17.11 & 12 & 0 & 5.9 & 1.49 & -1.30 \\
\hline $2 \mathrm{H}-5,11$ & 15.61 & 17.11 & 12 & 0 & 5.9 & 1.59 & -1.22 \\
\hline $2 \mathrm{H}-5,21$ & 15.71 & 17.21 & 12 & 0 & 5.6 & 1.21 & -1.32 \\
\hline $2 \mathrm{H}-5,21$ & 15.71 & 17.21 & 12 & 0 & 4.8 & 1.47 & -1.49 \\
\hline $2 \mathrm{H}-5,31$ & 15.81 & 17.31 & 12 & 0 & 6.7 & 1.12 & -1.38 \\
\hline $2 \mathrm{H}-5,31$ & 15.81 & 17.31 & 12 & 0 & 6.7 & 1.06 & -1.31 \\
\hline $2 \mathrm{H}-5,41$ & 15.91 & 17.41 & 12 & 0 & 5.6 & 1.21 & -1.24 \\
\hline $2 \mathrm{H}-5,41$ & 15.91 & 17.41 & 12 & 0 & 6.3 & 1.29 & -1.07 \\
\hline $2 \mathrm{H}-5,51$ & 16.01 & 17.51 & 12 & 0 & 5.6 & 1.22 & -1.41 \\
\hline $2 \mathrm{H}-5,51$ & 16.01 & 17.51 & 12 & 0 & 6.3 & 1.17 & -1.47 \\
\hline $2 \mathrm{H}-5,61$ & 16.11 & 17.61 & 12 & 0 & 5.2 & 1.63 & -1.43 \\
\hline $2 \mathrm{H}-5,61$ & 16.11 & 17.61 & 12 & 0 & 6.7 & 1.52 & -1.25 \\
\hline $2 \mathrm{H}-5,71$ & 16.21 & 17.71 & 12 & 0 & 4.1 & 1.31 & -1.32 \\
\hline $2 \mathrm{H}-5,71$ & 16.21 & 17.71 & 12 & 0 & 4.4 & 1.47 & -1.32 \\
\hline $2 \mathrm{H}-5,81$ & 16.31 & 17.81 & 12 & 0 & 5.6 & 1.36 & -1.59 \\
\hline $2 \mathrm{H}-5,81$ & 16.31 & 17.81 & 12 & 0 & 5.6 & 1.35 & -1.40 \\
\hline
\end{tabular}


Appendix E (continued).

\begin{tabular}{|c|c|c|c|c|c|c|c|}
\hline $\begin{array}{l}\text { Core, section, } \\
\text { interval (cm) }\end{array}$ & $\begin{array}{l}\text { ODP } \\
\text { depth } \\
\text { (mbsf) }\end{array}$ & $\begin{array}{l}\text { Composite } \\
\text { depth } \\
\text { (m) }\end{array}$ & $\begin{array}{l}\text { Number of } \\
\text { foraminifers } \\
\text { analyzed }\end{array}$ & $\begin{array}{c}\text { Number of } \\
\text { foraminifers } \\
\text { with sacs }\end{array}$ & $\begin{array}{c}\text { Transducer } \\
\text { pressure } \\
\text { (mbar) }\end{array}$ & $\begin{array}{l}\delta^{13} \mathrm{C} \\
\%_{0} \text { to } \\
\text { (PDB) }\end{array}$ & $\begin{array}{l}\delta^{18} \mathrm{O} \\
\% 00 \text { to } \\
\text { (PDB) }\end{array}$ \\
\hline \multicolumn{8}{|l|}{ 121-758B- (Cont). } \\
\hline $3 \mathrm{H}-3,111$ & 23.01 & 26.83 & 12 & 0 & 5.9 & 1.19 & -1.16 \\
\hline $3 \mathrm{H}-3,111$ & 23.01 & 26.83 & 13 & 0 & 6.7 & 1.31 & -1.37 \\
\hline $3 \mathrm{H}-3,121$ & 23.11 & 26.93 & 12 & 0 & 7.0 & 1.33 & -1.64 \\
\hline $3 \mathrm{H}-3,121$ & 23.11 & 26.93 & 12 & 0 & 7.0 & 1.35 & -1.54 \\
\hline $3 \mathrm{H}-3,131$ & 23.21 & 27.03 & 12 & 0 & 7.8 & 1.31 & -1.43 \\
\hline $3 \mathrm{H}-3,141$ & 23.31 & 27.13 & 12 & 0 & 8.1 & 1.62 & -1.36 \\
\hline $3 \mathrm{H}-4,1$ & 23.41 & 27.23 & 12 & 0 & 8.1 & 1.62 & -1.50 \\
\hline $3 \mathrm{H}-4,11$ & 23.51 & 27.33 & 12 & 0 & 6.7 & 1.22 & -1.76 \\
\hline $3 \mathrm{H}-4,11$ & 23.51 & 27.33 & 12 & 0 & 8.5 & 1.39 & -1.69 \\
\hline $3 \mathrm{H}-4,21$ & 23.61 & 27.43 & 12 & 0 & 7.4 & 1.42 & -1.12 \\
\hline $3 \mathrm{H}-4,21$ & 23.61 & 27.43 & 12 & 0 & 7.0 & 1.41 & -1.18 \\
\hline $3 \mathrm{H}-4,31$ & 23.71 & 27.53 & 12 & 0 & 7.4 & 1.34 & -1.38 \\
\hline $3 \mathrm{H}-4,31$ & 23.71 & 27.53 & 16 & 0 & 10.0 & 1.25 & -1.52 \\
\hline $3 \mathrm{H}-4,41$ & 23.81 & 27.63 & 12 & 0 & 7.0 & 1.52 & -1.17 \\
\hline $3 \mathrm{H}-4,41$ & 23.81 & 27.63 & 12 & 0 & 8.1 & 1.42 & -1.39 \\
\hline $3 \mathrm{H}-4,51$ & 23.91 & 27.73 & 12 & 0 & 6.7 & 1.80 & -1.34 \\
\hline $3 \mathrm{H}-4,73$ & 24.13 & 27.95 & 12 & 0 & 6.3 & 1.57 & -1.29 \\
\hline $3 \mathrm{H}-4,81$ & 24.21 & 28.03 & 12 & 0 & 6.3 & 1.37 & -1.45 \\
\hline $3 \mathrm{H}-4,9 \mathrm{I}$ & 24.31 & 28.13 & 12 & 0 & 7.8 & 1.44 & -1.65 \\
\hline $3 \mathrm{H}-4,101$ & 24.41 & 28.23 & 12 & 0 & 8.1 & 1.51 & -1.66 \\
\hline $3 \mathrm{H}-4,111$ & 24.51 & 28.33 & 12 & 0 & 7.4 & 1.59 & -1.04 \\
\hline $3 \mathrm{H}-4,111$ & 24.51 & 28.33 & 12 & 0 & 9.3 & 1.49 & -1.40 \\
\hline $3 \mathrm{H}-4,121$ & 24.61 & 28.43 & 12 & 0 & 7.4 & 1.49 & -1.38 \\
\hline $3 \mathrm{H}-4,131$ & 24.71 & 28.53 & 12 & 0 & 5.6 & 1.61 & -1.49 \\
\hline $3 \mathrm{H}-4,141$ & 24.81 & 28.63 & 12 & 0 & 7.0 & 1.67 & -1.30 \\
\hline $3 \mathrm{H}-4,141$ & 24.81 & 28.63 & 12 & 0 & 7.4 & 1.64 & -1.45 \\
\hline $3 \mathrm{H}-5,1$ & 24.91 & 28.73 & 12 & 0 & 5.9 & 1.51 & -1.57 \\
\hline $3 \mathrm{H}-5,1$ & 24.91 & 28.73 & 12 & 5 & 5.9 & 1.66 & -1.67 \\
\hline $3 \mathrm{H}-5,11$ & 25.01 & 28.83 & 12 & 0 & 1.9 & 1.55 & -0.98 \\
\hline $3 \mathrm{H}-5,11$ & 25.01 & 28.83 & 12 & 2 & 5.2 & 1.36 & -1.16 \\
\hline $3 \mathrm{H}-5,21$ & 25.11 & 28.93 & 12 & 0 & 6.7 & 1.63 & -1.33 \\
\hline $3 \mathrm{H}-5,2 \mathrm{I}$ & 25.11 & 28.93 & 12 & 0 & 5.9 & 1.60 & -1.42 \\
\hline $3 \mathrm{H}-5,31$ & 25.21 & 29.03 & 12 & 0 & 5.9 & 1.61 & -1.75 \\
\hline $3 \mathrm{H}-5,31$ & 25.21 & 29.03 & 12 & 0 & 6.3 & 1.48 & -1.79 \\
\hline $3 \mathrm{H}-5,41$ & 25.31 & 29.13 & 12 & 0 & 4.8 & 1.62 & -1.20 \\
\hline $3 \mathrm{H}-5,41$ & 25.31 & 29.13 & 12 & 0 & 7.4 & 1.48 & -1.44 \\
\hline $3 \mathrm{H}-5,51$ & 25.41 & 29.23 & 12 & 0 & 2.6 & 1.44 & -1.35 \\
\hline $3 \mathrm{H}-5,51$ & 25.41 & 29.23 & 12 & 0 & 7.4 & 1.72 & -1.59 \\
\hline $3 \mathrm{H}-5,61$ & 25.51 & 29.33 & 12 & 0 & 5.6 & 1.35 & -1.57 \\
\hline $3 \mathrm{H}-5,61$ & 25.51 & 29.33 & 12 & 0 & 5.9 & 1.28 & -2.07 \\
\hline $3 \mathrm{H}-5,71$ & 25.61 & 29.43 & 12 & 0 & 4.4 & 1.07 & -2.34 \\
\hline $3 \mathrm{H}-5,71$ & 25.61 & 29.43 & 12 & 0 & 5.2 & 1.60 & -1.63 \\
\hline $3 \mathrm{H}-5,71$ & 25.61 & 29.43 & 12 & 0 & 5.9 & 1.52 & -1.70 \\
\hline $3 \mathrm{H}-5,81$ & 25.71 & 29.53 & 12 & 0 & 5.6 & 1.49 & -1.67 \\
\hline $3 \mathrm{H}-5,81$ & 25.71 & 29.53 & 12 & 0 & 5.9 & 1.54 & -1.69 \\
\hline $3 \mathrm{H}-5,91$ & 25.81 & 29.63 & 12 & 0 & 6.7 & 1.54 & -1.38 \\
\hline $3 \mathrm{H}-5,101$ & 25.91 & 29.73 & 12 & 0 & 7.4 & 1.60 & -1.10 \\
\hline $3 \mathrm{H}-5,111$ & 26.01 & 29.83 & 12 & 0 & 7.8 & 1.53 & -1.21 \\
\hline $4 \mathrm{H}-5,71$ & 35.11 & 38.95 & 12 & 0 & 5.2 & 1.41 & -1.35 \\
\hline $4 \mathrm{H}-5,81$ & 35.21 & 39.05 & 12 & 0 & 5.6 & 1.26 & -1.53 \\
\hline $4 \mathrm{H}-5,91$ & 35.31 & 39.15 & 12 & 0 & 7.0 & 1.45 & -1.80 \\
\hline $4 \mathrm{H}-5,101$ & 35.41 & 39.25 & 12 & 0 & 6.7 & 1.44 & -1.35 \\
\hline $4 \mathrm{H}-5,111$ & 35.51 & 39.35 & 12 & 0 & 7.4 & 1.28 & -1.23 \\
\hline $4 \mathrm{H}-5,121$ & 35.61 & 39.45 & 12 & 0 & 5.6 & 1.04 & -1.53 \\
\hline $4 \mathrm{H}-5,131$ & 35.71 & 39.55 & 12 & 0 & 5.9 & 1.49 & -1.46 \\
\hline $4 \mathrm{H}-5,141$ & 35.81 & 39.65 & 12 & 0 & 5.9 & 1.35 & -1.53 \\
\hline $4 \mathrm{H}-6,1$ & 35.91 & 39.75 & 12 & 0 & 6.3 & 1.33 & -1.64 \\
\hline $4 \mathrm{H}-6,11$ & 36.01 & 39.85 & 12 & 0 & 6.7 & 1.38 & -0.95 \\
\hline $4 \mathrm{H}-6,21$ & 36.11 & 39.95 & 12 & 0 & 7.4 & 1.25 & -1.30 \\
\hline $4 \mathrm{H}-6,31$ & 36.21 & 40.05 & 12 & 0 & 6.7 & 1.28 & -1.50 \\
\hline $4 \mathrm{H}-6,41$ & 36.31 & 40.15 & 12 & 0 & 6.3 & 1.38 & -1.67 \\
\hline
\end{tabular}


APPENDIX F
Site 758 Composite Records of Mean $\delta^{13} \mathrm{C}, \delta^{18} \mathrm{O}, \mathrm{CaCO}_{3}$, Density, Coarse Fraction, and Interpolated Magnetic Susceptibility Data

\begin{tabular}{|c|c|c|c|c|c|c|c|c|c|c|c|c|c|c|}
\hline $\begin{array}{l}\text { Core, section, } \\
\text { interval }(\mathrm{cm})\end{array}$ & $\begin{array}{l}\text { ODP } \\
\text { depth } \\
\text { (mbsf) }\end{array}$ & $\begin{array}{c}\text { Composite } \\
\text { depth } \\
\text { (m) }\end{array}$ & $\begin{array}{c}\text { Magnetic } \\
\text { age } \\
\text { (m.y.) }\end{array}$ & $\begin{array}{c}\text { Magnetic } \\
\text { sedimentation } \\
\text { rate } \\
(\mathrm{m} / \mathrm{m} . \mathrm{y} .)\end{array}$ & $\begin{array}{c}\delta^{18} \mathrm{O} \\
\text { age } \\
\text { (m.y.) }\end{array}$ & $\begin{array}{c}\delta^{18} \mathrm{O} \\
\text { sedimentation } \\
\text { rate } \\
(\mathrm{m} / \mathrm{m} . \mathrm{y} .)\end{array}$ & $\begin{array}{c}\text { Mean } \\
\left.\text { (wt } \% \mathrm{CaCO}_{3}\right)\end{array}$ & $\begin{array}{c}\text { Magnetic } \\
\mathrm{CaCO}_{3} \text { MAR } \\
\left(\mathrm{g} / \mathrm{cm}^{2} / \mathrm{k} . \mathrm{y} .\right)\end{array}$ & $\begin{array}{l}\delta^{13} \mathrm{C} \\
\% 0 \text { to } \\
\text { (PDB) }\end{array}$ & $\begin{array}{l}\delta^{18} \mathrm{O} \\
\% \% \text { to } \\
\text { (PDB) }\end{array}$ & $\begin{array}{c}\text { Dry-bulk } \\
\text { density } \\
\left(\mathrm{g} / \mathrm{cm}^{3}\right)\end{array}$ & $\begin{array}{c}\text { Coarse } \\
\text { fraction } \\
(\mathrm{wt} \%>150 \mu \mathrm{m})\end{array}$ & $\begin{array}{c}\text { Interpolated MS } \\
\text { K (10-6) } \\
\text { (cgs) }\end{array}$ & Comment \\
\hline \multicolumn{15}{|l|}{$121-758 \mathrm{~A}-$} \\
\hline $1 \mathrm{H}-1,1$ & 0.01 & 0.01 & 0.00060 & 16.7 & 0.00055 & 23.08 & 64.63 & 0.56 & 1.56 & -2.25 & 0.527 & 28.49 & 2.50 & \\
\hline $1 \mathrm{H}-1,11$ & 0.11 & 0.11 & 0.00660 & 16.7 & 0.00600 & 23.08 & 61.67 & 0.56 & 1.60 & -2.26 & 0.542 & 19.33 & 5.23 & \\
\hline $1 \mathrm{H}-1,21$ & 0.21 & 0.21 & 0.01260 & 16.7 & 0.01033 & 23.08 & 56.96 & 0.57 & 1.49 & -2.13 & 0.599 & 20.01 & 6.20 & \\
\hline $1 \mathrm{H}-1,31$ & 0.31 & 0.31 & 0.01859 & 16.7 & 0.01467 & 23.08 & 58.88 & 0.64 & 1.41 & -1.45 & 0.656 & 21.68 & 8.07 & \\
\hline $1 \mathrm{H}-1,41$ & 0.41 & 0.41 & 0.02459 & 16.7 & 0.01900 & 20.59 & 54.06 & 0.59 & 1.60 & -0.33 & 0.656 & 14.60 & 9.77 & \\
\hline $1 \mathrm{H}-1,51$ & 0.51 & 0.51 & 0.03059 & 16.7 & 0.02386 & 20.59 & 56.75 & 0.58 & 1.66 & -0.50 & 0.613 & 16.12 & 8.90 & \\
\hline $1 \mathrm{H}-1,61$ & 0.61 & 0.61 & 0.03659 & 16.7 & 0.02871 & 20.59 & 55.03 & 0.63 & 1.71 & -0.69 & 0.691 & 18.25 & 10.53 & \\
\hline $1 \mathrm{H}-1,71$ & 0.71 & 0.71 & 0.04259 & 16.7 & 0.03357 & 20.59 & 55.51 & 0.61 & 1.58 & -0.89 & 0.656 & 17.97 & 10.63 & \\
\hline $1 \mathrm{H}-1,81$ & 0.81 & 0.81 & 0.04859 & 16.7 & 0.03843 & 20.59 & 59.07 & 0.64 & 1.68 & -0.95 & 0.648 & 20.85 & 6.70 & \\
\hline $1 \mathrm{H}-1,91$ & 0.91 & 0.91 & 0.05459 & 16.7 & 0.04329 & 20.59 & 60.25 & 0.74 & 1.57 & -0.88 & 0.741 & 15.85 & 7.57 & \\
\hline $1 \mathrm{H}-1,101$ & 1.01 & 1.01 & 0.06058 & 16.7 & 0.04814 & 20.59 & 57.70 & 0.64 & 1.64 & -1.01 & 0.670 & 16.74 & 3.63 & \\
\hline $1 \mathrm{H}-1,111$ & 1.11 & 1.11 & 0.06658 & 16.7 & 0.05300 & 20.83 & 59.68 & 0.69 & 1.53 & -1.10 & 0.691 & 17.73 & 6.20 & \\
\hline $1 \mathrm{H}-1,121$ & 1.21 & 1.21 & 0.07258 & 16.7 & 0.05780 & 20.83 & 54.27 & 0.59 & 1.40 & -1.02 & 0.656 & 14.04 & 4.67 & \\
\hline $1 \mathrm{H}-1,131$ & 1.31 & 1.31 & 0.07858 & 16.7 & 0.06260 & 22.73 & 45.48 & 0.51 & 1.39 & -0.86 & 0.670 & 9.27 & 8.47 & \\
\hline $1 \mathrm{H}-1,141$ & 1.41 & 1.41 & 0.08458 & 16.7 & 0.06700 & 25.00 & 45.20 & 0.57 & 1.67 & -0.86 & 0.762 & 10.12 & 9.50 & \\
\hline $1 \mathrm{H}-2,1$ & 1.51 & 1.51 & 0.09058 & 16.7 & 0.07100 & 25.00 & 35.73 & 0.47 & 1.19 & -1.02 & 0.787 & 8.88 & 15.03 & Contains some ash $\mathrm{A}$ \\
\hline $1 \mathrm{H}-2,11$ & 1.61 & 1.61 & 0.09657 & 16.7 & & & 3.64 & 0.06 & & & 0.997 & & 50.90 & Ash A, not processed \\
\hline $1 \mathrm{H}-2,21$ & 1.71 & 1.71 & 0.10257 & 16.7 & & & 2.70 & 0.04 & & & 0.898 & & 35.90 & Ash $\mathrm{A}$, not processed \\
\hline $1 \mathrm{H}-2,31$ & 1.81 & 1.81 & 0.10857 & 16.7 & & & 4.21 & 0.06 & & & 0.819 & & 31.27 & Ash $\mathrm{A}$, not processed \\
\hline $1 \mathrm{H}-2,41$ & 1.91 & 1.91 & 0.11457 & 16.7 & 0.07614 & & 61.67 & 0.75 & 1.45 & -1.34 & 0.727 & 12.79 & 12.23 & \\
\hline $1 \mathrm{H}-2,51$ & 2.01 & 2.01 & 0.12057 & 16.7 & & & 9.53 & 0.15 & & & 0.969 & & 113.50 & Ash B, not processed \\
\hline $1 \mathrm{H}-2,61$ & 2.11 & 2.11 & 0.12657 & 16.7 & 0.07871 & 10.53 & 60.48 & 0.73 & 1.57 & -1.38 & 0.720 & 12.91 & 5.57 & \\
\hline $1 \mathrm{H}-2,71$ & 2.21 & 2.21 & 0.13256 & 16.7 & 0.08000 & 10.53 & 57.76 & 0.73 & 1.48 & -1.52 & 0.755 & 12.60 & 5.07 & \\
\hline $1 \mathrm{H}-2,81$ & 2.31 & 2.31 & 0.13856 & 16.7 & 0.08950 & 10.53 & 67.15 & 0.87 & 1.41 & -1.38 & 0.777 & 10.23 & 4.80 & \\
\hline $1 \mathrm{H}-2,91$ & 2.41 & 2.41 & 0.14456 & 16.7 & 0.09900 & 13.04 & 58.98 & 0.76 & 1.48 & -1.73 & 0.769 & 12.29 & 10.17 & \\
\hline $1 \mathrm{H}-2,101$ & 2.51 & 2.51 & 0.15056 & 16.7 & 0.10667 & 13.04 & 57.66 & 0.73 & 1.26 & -1.69 & 0.755 & 9.94 & 13.63 & \\
\hline $1 \mathrm{H}-2,111$ & 2.61 & 2.61 & 0.15656 & 16.7 & 0.11433 & 13.04 & 57.40 & 0.74 & 1.16 & -1.56 & 0.769 & 8.27 & 13.80 & \\
\hline $1 \mathrm{H}-2,121$ & 2.71 & 2.71 & 0.16256 & 16.7 & 0.12200 & 23.08 & 51.61 & 0.65 & 1.07 & -1.92 & 0.755 & 10.93 & 11.53 & \\
\hline $1 \mathrm{H}-2,131$ & 2.81 & 2.81 & 0.16855 & 16.7 & 0.12633 & 23.07 & 50.19 & 0.59 & 1.06 & -1.50 & 0.705 & 14.89 & 12.83 & \\
\hline $1 \mathrm{H}-2,141$ & 2.91 & 2.91 & 0.17455 & 16.7 & 0.13067 & 23.08 & 51.83 & 0.68 & 1.14 & -0.93 & 0.784 & 18.07 & 14.40 & \\
\hline $1 \mathrm{H}-3,1$ & 3.01 & 3.01 & 0.18055 & 16.7 & 0.13500 & 13.89 & 56.24 & 0.75 & 1.20 & -0.37 & 0.798 & 16.87 & 10.90 & \\
\hline $1 \mathrm{H}-3,11$ & 3.11 & 3.11 & 0.18655 & 16.7 & 0.14220 & 13.89 & 57.90 & 0.73 & 1.39 & -0.55 & 0.755 & 22.75 & 11.53 & \\
\hline $1 \mathrm{H}-3,21$ & 3.21 & 3.21 & 0.19255 & 16.7 & 0.14940 & 13.89 & 49.60 & 0.58 & 1.37 & -0.66 & 0.698 & 17.81 & 11.20 & \\
\hline $1 \mathrm{H}-3,31$ & 3.31 & 3.31 & 0.19855 & 16.7 & 0.15660 & 13.89 & 54.77 & 0.68 & 1.35 & -0.65 & 0.741 & 19.87 & 8.00 & \\
\hline $1 \mathrm{H}-3,41$ & 3.41 & 3.41 & 0.20454 & 16.7 & 0.16380 & 13.89 & 54.65 & 0.71 & 1.17 & -0.75 & 0.784 & 15.59 & 6.73 & \\
\hline $1 \mathrm{H}-3,51$ & 3.51 & 3.51 & 0.21054 & 16.7 & 0.17100 & 16.67 & 55.76 & 0.70 & 1.21 & -1.25 & 0.755 & 16.85 & 6.00 & \\
\hline $1 \mathrm{H}-3,61$ & 3.61 & 3.61 & 0.21654 & 16.7 & 0.17700 & 16.67 & 57.95 & 0.73 & 1.47 & -0.94 & 0.755 & 15.99 & 8.30 & \\
\hline $1 \mathrm{H}-3,71$ & 3.71 & 3.71 & 0.22254 & 16.7 & 0.18300 & 18.18 & 60.11 & 0.81 & 1.31 & -0.99 & 0.812 & 10.18 & 8.30 & \\
\hline $1 \mathrm{H}-3,81$ & 3.81 & 3.81 & 0.22854 & 16.7 & 0.18850 & 18.18 & 62.37 & 0.84 & 1.41 & -1.27 & 0.805 & 12.15 & 7.70 & \\
\hline $1 \mathrm{H}-3,91$ & 3.91 & 3.91 & 0.23454 & 16.7 & 0.19400 & 9.09 & 55.54 & 0.75 & 1.41 & -1.95 & 0.812 & 10.53 & 9.63 & \\
\hline $1 \mathrm{H}-3,101$ & 4.01 & 4.01 & 0.24053 & 16.7 & 0.20500 & 15.45 & 65.38 & 0.89 & 1.48 & -1.27 & 0.812 & 12.01 & 10.10 & \\
\hline $1 \mathrm{H}-3,111$ & 4.11 & 4.11 & 0.24653 & 16.7 & 0.21147 & 16.41 & 67.08 & 0.86 & 1.45 & -1.56 & 0.769 & 10.46 & 6.10 & \\
\hline $1 \mathrm{H}-3,121$ & 4.21 & 4.21 & 0.25253 & 16.7 & 0.21757 & 19.16 & 62.28 & 0.77 & 1.55 & -1.70 & 0.741 & 15.66 & 7.50 & \\
\hline $1 \mathrm{H}-3,131$ & 4.31 & 4.31 & 0.25853 & 16.7 & 0.22278 & 19.17 & 57.23 & 0.69 & 1.40 & -1.28 & 0.727 & 14.32 & 11.37 & \\
\hline $1 \mathrm{H}-3,141$ & 4.41 & 4.41 & 0.26453 & 16.7 & 0.22800 & 23.00 & 59.30 & 0.85 & 1.42 & -0.97 & 0.855 & 12.02 & 10.70 & \\
\hline $1 \mathrm{H}-4,1$ & 4.51 & 4.51 & 0.27053 & 16.7 & 0.23235 & 23.00 & 62.19 & 0.81 & 1.47 & -1.04 & 0.778 & 6.74 & 7.54 & \\
\hline $1 \mathrm{H}-4,11$ & 4.61 & 4.61 & 0.27652 & 16.7 & 0.23670 & 26.95 & 60.07 & 0.74 & 1.35 & -1.46 & 0.741 & 11.22 & 8.27 & \\
\hline $1 \mathrm{H}-4,21$ & 4.71 & 4.71 & 0.28252 & 16.7 & 0.24041 & 29.09 & 55.52 & 0.65 & 1.26 & -1.29 & 0.698 & 18.39 & 7.20 & \\
\hline $1 \mathrm{H}-4,31$ & 4.81 & 4.81 & 0.28852 & 16.7 & 0.24384 & 29.10 & 53.02 & 0.65 & 1.52 & -0.90 & 0.734 & 14.64 & 8.47 & \\
\hline $1 \mathrm{H}-4,41$ & 4.91 & 4.91 & 0.29452 & 16.7 & 0.24728 & 22.80 & 57.60 & 0.78 & 1.30 & -0.58 & 0.812 & 12.78 & 13.10 & \\
\hline $1 \mathrm{H}-4,51$ & 5.01 & 5.01 & 0.30052 & 16.7 & 0.25167 & 18.75 & 59.01 & 0.76 & 1.39 & -0.63 & 0.769 & 14.12 & 16.40 & \\
\hline $1 \mathrm{H}-4,61$ & 5.11 & 5.11 & 0.30652 & 16.7 & 0.25700 & 17.50 & 58.68 & 0.71 & 1.21 & -0.94 & 0.727 & 16.24 & 8.47 & \\
\hline $1 \mathrm{H}-4,71$ & 5.21 & 5.21 & 0.31251 & 16.7 & 0.26271 & 17.50 & 50.51 & 0.64 & 1.17 & -0.88 & 0.755 & 9.14 & 10.27 & \\
\hline $1 \mathrm{H}-4,81$ & 5.31 & 5.31 & 0.31851 & 16.7 & 0.26843 & 17.51 & 49.31 & 0.65 & 1.31 & -0.69 & 0.791 & 5.61 & 14.10 & \\
\hline
\end{tabular}




$\begin{array}{llll}1 \mathrm{H}-3,81 & 3.81 & 5.32 & 0.31911 \\ 1 \mathrm{H}-3,91 & 3.91 & 5.42 & 0.32511 \\ 1 \mathrm{H}-3,101 & 4.01 & 5.52 & 0.33111 \\ 1 \mathrm{H}-3,111 & 4.11 & 5.62 & 0.33711 \\ 1 \mathrm{H}-3,121 & 4.21 & 5.72 & 0.34311 \\ 1 \mathrm{H}-3,131 & 4.31 & 5.82 & 0.34910 \\ 1 \mathrm{H}-3,141 & 4.41 & 5.92 & 0.35510 \\ 1 \mathrm{H}-4,1 & 4.51 & 6.02 & 0.36110 \\ 1 \mathrm{H}-4,11 & 4.61 & 6.12 & 0.36710 \\ 1 \mathrm{H}-4,21 & 4.71 & 6.22 & 0.37310 \\ 1 \mathrm{H}-4,31 & 4.81 & 6.32 & 0.37910 \\ 1 \mathrm{H}-4,41 & 4.91 & 6.42 & 0.38510 \\ 1 \mathrm{H}-4,51 & 5.01 & 6.52 & 0.39109 \\ 1 \mathrm{H}-4,61 & 5.11 & 6.62 & 0.39709 \\ 1 \mathrm{H}-4,71 & 5.21 & 6.72 & 0.40309 \\ 1 \mathrm{H}-4,81 & 5.31 & 6.82 & 0.40909 \\ 1 \mathrm{H}-4,91 & 5.41 & 6.92 & 0.41509 \\ 1 \mathrm{H}-4,101 & 5.51 & 7.02 & 0.42109 \\ 1 \mathrm{H}-4,111 & 5.61 & 7.12 & 0.42708 \\ 1 \mathrm{H}-4,121 & 5.71 & 7.22 & 0.43308 \\ 1 \mathrm{H}-4,131 & 5.81 & 7.32 & 0.43908 \\ 1 \mathrm{H}-4,141 & 5.91 & 7.42 & 0.44508\end{array}$

$\begin{array}{lll}16.7 & 0.26900 & 11.11 \\ 16.7 & 0.27800 & 11.11 \\ 16.7 & 0.28700 & 12.50 \\ 16.7 & 0.29500 & 15.48 \\ 16.7 & 0.30146 & 20.31 \\ 16.7 & 0.30639 & 20.31 \\ 16.7 & 0.31131 & 20.31 \\ 16.7 & 0.31623 & 20.31 \\ 16.7 & 0.32115 & 20.31 \\ 16.7 & 0.32608 & 20.31 \\ 16.7 & 0.33100 & 30.00 \\ 16.7 & 0.33433 & 29.99 \\ 16.7 & 0.33767 & 30.00 \\ 16.7 & 0.34100 & 12.66 \\ 16.7 & 0.34890 & 12.66 \\ 16.7 & 0.35680 & 12.66 \\ 16.7 & 0.36470 & 12.66 \\ 16.7 & 0.37261 & 12.66 \\ 16.7 & 0.38051 & 12.66 \\ 16.7 & 0.38841 & 12.66 \\ 16.7 & & \\ 16.7 & 0.40421 & 12.66\end{array}$

$\begin{array}{ll}49.10 & 0.6 \\ 53.90 & 0.76 \\ 61.74 & 0.79 \\ 59.60 & 0.7 \\ 66.99 & 0.9 \\ 73.88 & 1.0 \\ 68.69 & 0.98 \\ 60.63 & 0.80 \\ 62.54 & 0.85 \\ 71.18 & 1.00 \\ 65.70 & 0.84 \\ 55.04 & 0.69 \\ 56.28 & 0.71 \\ 57.75 & 0.77 \\ 57.88 & 0.78 \\ 53.87 & 0.67 \\ 55.63 & 0.73 \\ 57.83 & 0.76 \\ 57.61 & 0.72 \\ 56.79 & 0.76 \\ 52.04 & 0.70 \\ 53.18 & 0.75\end{array}$

0.61
0.76
0.79
0.71
0.91
1.01
0.98
0.80
0.85
1.00
0.84
0.69
0.71
0.77
0.78
0.67
0.73
0.76
0.72
0.76
0.70
0.75

$\begin{array}{lll}1.48 & -0.63 & 0.741 \\ 1.65 & -0.93 & 0.841 \\ 1.55 & -1.28 & 0.769 \\ 1.46 & -0.94 & 0.712 \\ 1.61 & -1.12 & 0.812 \\ 1.51 & -1.18 & 0.819 \\ 1.50 & -1.48 & 0.855 \\ 1.29 & -1.57 & 0.791 \\ 1.19 & -1.68 & 0.812 \\ 1.28 & -1.70 & 0.841 \\ 1.04 & -1.73 & 0.762 \\ 0.99 & -1.50 & 0.755 \\ 1.06 & -0.93 & 0.755 \\ 1.34 & -0.49 & 0.798 \\ 1.40 & -0.77 & 0.812 \\ 1.30 & -0.82 & 0.741 \\ 1.49 & -0.78 & 0.784 \\ 1.43 & -1.17 & 0.784 \\ 1.52 & -1.52 & 0.748 \\ 1.45 & -1.54 & 0.798 \\ & & 0.805 \\ 1.81 & -1.81 & 0.841\end{array}$

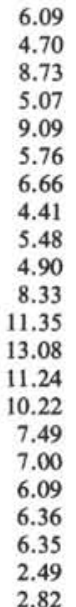

13.30

9.87

9.20

7.70

6.20

9.43

11.40
9.00

10.23

12.70

13.80
14.57

14.57
12.30

12.30
13.90

13.90
12.87

11.47
10.80

11.30

9.73
10.70

Insufficient foraminifers

1-758A-

$\begin{array}{llll}2 \mathrm{H}-1,1 & 6.01 & 7.43 & 0.44568\end{array}$

$\begin{array}{lllll}2 \mathrm{H}-1,11 & 6.01 & 7.43 & 0.44568 \\ & 6.11 & 7.53 & 0.45168\end{array}$

$2 \mathrm{H}-1,21 \quad 6.21 \quad 7.63$

$2 \mathrm{H}-1,31$

0.45768

0.46367

0.46967
0.47567

0.47567

$2 \mathrm{H}-1,51$

$2 \mathrm{H}-1,61$

$6.41-7.83$

$2 \mathrm{H}-1,71$

0.48767

0.49367

0.49966

$2 \mathrm{H}-1,91$

$2 \mathrm{H}-1,101$

$2 \mathrm{H}-1,121$

$2 \mathrm{H}-1,131$

$2 \mathrm{H}-1,14$

$2 \mathrm{H}-2,1$

$2 \mathrm{H}-2,21$

$2 \mathrm{H}-2,31$

$2 \mathrm{H}-2,41$

2H-2,

$2 \mathrm{H}-2,61$

(1)

$2 \mathrm{H}-2,91$

$2 \mathrm{H}-2,10$

$2 \mathrm{H}-2,11$

$2 \mathrm{H}-2,12$

2H-2, 13

$2 \mathrm{H}-3,1$

$2 \mathrm{H}-3,11$

$2 \mathrm{H}-3,31$

$2 \mathrm{H}-3,41$

$2 \mathrm{H}-3,51$

16.7
16.7
16.7
16.7
16.7
16.7
16.7
16.7
16.7
16.7
16.7
16.7
16.7
16.7
16.7
16.7
16.7
16.7
16.7
16.7
16.7
16.7
16.7
16.7
16.7
16.7
16.7
16.7
16.
16.7
16.7
16.7
16.7
16.7
16.7
16.7
16.7

0.62

$\begin{array}{lll}1.62 & -1.73 & 0.742\end{array}$

$\begin{array}{lll}1.44 & -1.72 & 0.712 \\ 1.44 & -0.49 & 0.798\end{array}$

$\begin{array}{lll}1.44 & -0.49 & 0.798 \\ 1.54 & -0.56 & 0.727\end{array}$

$\begin{array}{lll}1.56 & -0.63 & 0.712 \\ 1.61 & -1.05 & 0.784\end{array}$

$\begin{array}{lll}1.61 & -1.05 & 0.784 \\ 1.66 & -1.32 & 0.755\end{array}$

$\begin{array}{lll}1.66 & -1.32 & 0.755 \\ 1.72 & -1.30 & 0.755\end{array}$

$\begin{array}{lll}2.06 & -1.64 & 0.748\end{array}$

$\begin{array}{lll}1.84 & -1.45 & 0.798 \\ 1.71 & -1.50 & 0.769\end{array}$

$\begin{array}{ll}1.84 & -1.45 \\ & 0.798 \\ 1.57 & 0.933\end{array}$

$\begin{array}{lll}1.57 & -1.27 & 0.812 \\ 1.56 & -1.48 & 0.762\end{array}$

$\begin{array}{lll}1.56 & -1.48 & 0.762 \\ 1.52 & -1.30 & 0.741\end{array}$

$\begin{array}{lll}1.36 & -1.20 & 0.758 \\ 1.32 & -1.13 & 0.777\end{array}$

$\begin{array}{lll}1.32 & -1.13 & 0.777 \\ 1.40 & -1.33 & 0.841\end{array}$

$\begin{array}{lll}1.44 & -1.60 & 0.848\end{array}$

$\begin{array}{lll}1.48 & -1.62 & 0.784 \\ 1.52 & -2.00 & 0.769\end{array}$

$\begin{array}{lll}1.52 & -2.00 & 0.769 \\ 1.31 & -1.46 & 0.826\end{array}$

$\begin{array}{lll}1.40 & -1.34 & 0.812\end{array}$

$\begin{array}{lll}1.26 & -1.63 & 0.826\end{array}$

$\begin{array}{lll}1.21 & -1.71 & 0.826 \\ 1.23 & -1.47 & 0.784\end{array}$

$\begin{array}{lll}1.21 & -1.66 & 0.741\end{array}$

$\begin{array}{lll}1.28 & -1.07 & 0.712 \\ 1.18 & -0.56 & 0.698\end{array}$

$\begin{array}{lll}1.37 & -0.63 & 0.698\end{array}$

$\begin{array}{lll}1.41 & -0.77 & 0.912\end{array}$

$\begin{array}{lll}1.20 & -0.99 & 0.748 \\ 1.21 & -1.01 & 0.784\end{array}$

$\begin{array}{lll}1.21 & -1.01 & 0.784 \\ 1.41 & -1.37 & 0.755\end{array}$

$\begin{array}{lll}1.41 & -1.43 & 0.755 \\ 1.17 & -1.43 & 0.769\end{array}$

$\begin{array}{lll}1.17 & -1.43 & 0.769 \\ 1.37 & -1.63 & 0.826 \\ 1.46 & -1.63 & 0.798\end{array}$

14.58
16.52

16.52
19.05

$\begin{array}{r}2.68 \\ 2.57 \\ 8.46 \\ 10.17 \\ 7.88 \\ 5.83 \\ 6.97 \\ 5.63 \\ 3.89 \\ 3.51 \\ 1.90 \\ 2.95 \\ 6.77 \\ 9.53 \\ 9.41 \\ 15.52 \\ 9.86 \\ 6.94 \\ 7.99 \\ 6.64 \\ 8.93 \\ 13.08 \\ 11.70 \\ 10.52 \\ 8.31 \\ 14.11 \\ 17.63 \\ 7.56 \\ 13.41 \\ 11.69 \\ 15.11 \\ 7.87 \\ 8.97 \\ 9.86 \\ 5.08 \\ 11.64 \\ \hline\end{array}$

13.30

14.80

12.10

11.40
11.07

11.07

12.80

13.13

23.13

10.57

9.27

6.50

8.60

13.80

(1.77

14.27

11.60
11.03

8.57

12.50

0.43

10.43

(2.60

10.27

10.10

10.93

15.30

12.00

12.43
10.90

10.90
13.40
Contains some ash C Contains some ash C

(0.23 


\begin{tabular}{|c|c|c|c|c|c|c|c|c|c|c|c|c|c|c|}
\hline $\begin{array}{l}\text { Core, section, } \\
\text { interval }(\mathrm{cm})\end{array}$ & $\begin{array}{l}\text { ODP } \\
\text { depth } \\
\text { (mbsf) }\end{array}$ & $\begin{array}{c}\text { Composite } \\
\text { depth } \\
\text { (m) }\end{array}$ & $\begin{array}{l}\text { Magnetic } \\
\text { age } \\
\text { (m.y.) }\end{array}$ & $\begin{array}{c}\text { Magnetic } \\
\text { sedimentation } \\
\text { rate } \\
(\mathrm{m} / \mathrm{m} \cdot \mathrm{y} .)\end{array}$ & $\begin{array}{l}\delta^{18} \mathrm{O} \\
\text { age } \\
\text { (m.y.) }\end{array}$ & $\begin{array}{c}\delta^{18} \mathrm{O} \\
\text { sedimentation } \\
\text { rate } \\
(\mathrm{m} / \mathrm{m} . \mathrm{y} .)\end{array}$ & $\begin{array}{c}\text { Mean } \\
\left(\mathrm{wt} \% \mathrm{CaCO}_{3} \text { ) }\right.\end{array}$ & $\begin{array}{c}\text { Magnetic } \\
\mathrm{CaCO}_{3} \text { MAR } \\
\left(\mathrm{g} / \mathrm{cm}^{2} / \mathrm{k} . \mathrm{y} .\right)\end{array}$ & $\begin{array}{l}\delta^{13} \mathrm{C} \\
\%_{0} \text { to } \\
\text { (PDB) }\end{array}$ & $\begin{array}{l}\delta^{18} \mathrm{O} \\
\%_{0} \text { to } \\
\text { (PDB) }\end{array}$ & $\begin{array}{c}\text { Dry-bulk } \\
\text { density } \\
\left(\mathrm{g} / \mathrm{cm}^{3}\right)\end{array}$ & $\begin{array}{c}\text { Coarse } \\
\text { fraction } \\
(\mathrm{wt} \%>150 \mu \mathrm{m})\end{array}$ & $\begin{array}{c}\text { Interpolated MS } \\
\text { K (10-6) } \\
\text { (cgs) }\end{array}$ & Comment \\
\hline \multicolumn{15}{|l|}{ 121-758A-(Cont.) } \\
\hline $2 \mathrm{H}-3,71$ & 9.71 & 11.13 & 0.66762 & 16.7 & 0.68688 & 19.05 & 69.72 & 0.88 & 1.29 & -1.49 & 0.755 & 19.84 & 6.10 & \\
\hline $2 \mathrm{H}-3,8 \mathrm{I}$ & 9.81 & 11.23 & 0.67362 & 16.7 & 0.69213 & 19.05 & 63.74 & 0.84 & 1.42 & -1.36 & 0.791 & 19.17 & 6.90 & \\
\hline $2 \mathrm{H}-3,91$ & 9.91 & 11.33 & 0.67961 & 16.7 & 0.69738 & 18.60 & 50.01 & 0.62 & 1.23 & -1.01 & 0.741 & 7.06 & 11.53 & \\
\hline $2 \mathrm{H}-3,101$ & 10.01 & 11.43 & 0.68561 & 16.7 & 0.70275 & 18.18 & 58.20 & 0.76 & 1.26 & -0.90 & 0.784 & 9.18 & 10.23 & \\
\hline $2 \mathrm{H}-3,111$ & 10.11 & 11.53 & 0.69161 & 16.7 & 0.70825 & 19.05 & 61.90 & 0.83 & 1.28 & -1.18 & 0.805 & 12.94 & 7.00 & \\
\hline $2 \mathrm{H}-3,121$ & 10.21 & 11.63 & 0.69761 & 16.7 & 0.71350 & 20.00 & 66.30 & 0.85 & 1.31 & -1.13 & 0.769 & 21.38 & 5.70 & \\
\hline $2 \mathrm{H}-3,131$ & 10.31 & 11.73 & 0.70361 & 16.7 & 0.71850 & 22.22 & 52.88 & 0.67 & 1.14 & -0.97 & 0.755 & 11.88 & 7.77 & \\
\hline $2 \mathrm{H}-3,141$ & 10.41 & 11.83 & 0.70961 & 16.7 & 0.72300 & 25.00 & 59.71 & 0.82 & 1.22 & -0.94 & 0.826 & 10.77 & 8.40 & \\
\hline $2 \mathrm{H}-4,1$ & 10.51 & 11.93 & 0.71560 & 16.7 & 0.72700 & 25.00 & 57.90 & 0.72 & 1.30 & -1.65 & 0.741 & 8.02 & 9.30 & \\
\hline $2 \mathrm{H}-4,11$ & 10.61 & 12.03 & 0.72160 & 16.7 & 0.73100 & 28.94 & 56.20 & 0.74 & 1.34 & -1.92 & 0.791 & 8.55 & 10.30 & \\
\hline $2 \mathrm{H}-4,2 \mathrm{I}$ & 10.71 & 12.13 & 0.72760 & 16.7 & 0.73446 & 28.94 & 42.43 & 0.57 & 1.21 & -1.77 & 0.812 & 5.76 & 10.70 & \\
\hline $2 \mathrm{H}-4,31$ & 10.81 & 12.23 & 0.73318 & 17.9 & & & 12.65 & 0.21 & & & 0.947 & & 13.23 & Ash D, not processed \\
\hline $2 \mathrm{H}-4,41$ & 10.91 & 12.33 & 0.73847 & 18.9 & & & 2.69 & 0.05 & & & 1.040 & & 34.80 & Ash $\mathrm{D}$, not processed \\
\hline $2 \mathrm{H}-4,51$ & 11.01 & 12.43 & 0.74377 & 18.9 & 0.74482 & 28.94 & 55.97 & 0.75 & 1.16 & -0.98 & 0.712 & 15.17 & 13.40 & \\
\hline $2 \mathrm{H}-4,61$ & 11.11 & 12.53 & 0.74906 & 18.9 & 0.74827 & 26.25 & 52.26 & 0.80 & 1.26 & -0.78 & 0.812 & 13.38 & 12.70 & \\
\hline $2 \mathrm{H}-4,71$ & 11.21 & 12.63 & 0.75435 & 18.9 & 0.75208 & 24.00 & 54.71 & 0.84 & 1.60 & -0.77 & 0.812 & 8.63 & 13.07 & \\
\hline $2 \mathrm{H}-4,81$ & 11.31 & 12.73 & 0.75965 & 18.9 & 0.75625 & 24.00 & 50.57 & 0.80 & 1.49 & -1.08 & 0.834 & 6.20 & 16.40 & \\
\hline $2 \mathrm{H}-4,91$ & 11.41 & 12.83 & 0.76494 & 18.9 & 0.76042 & 24.00 & 57.42 & 0.87 & 1.54 & -1.21 & 0.798 & 6.47 & 18.83 & Ash D \\
\hline $2 \mathrm{H}-4,101$ & 11.51 & 12.93 & 0.77024 & 18.9 & 0.76458 & 24.00 & 48.88 & 0.75 & 1.24 & -1.54 & 0.812 & 8.30 & 12.87 & \\
\hline $2 \mathrm{H}-4,111$ & 11.61 & 13.03 & 0.77553 & 18.9 & 0.76875 & 24.00 & 33.50 & 0.57 & 1.42 & -1.69 & 0.898 & 4.76 & 33.70 & Ash E, and below \\
\hline $2 \mathrm{H}-4,12 \mathrm{I}$ & 11.71 & 13.13 & 0.78082 & 18.9 & 0.77292 & 23.45 & 69.94 & 1.02 & 1.25 & -1.66 & 0.769 & 13.09 & 14.57 & \\
\hline $2 \mathrm{H}-4,131$ & 11.81 & 13.23 & 0.78612 & 18.9 & 0.77718 & 22.92 & 65.10 & 0.98 & 1.36 & -1.38 & 0.798 & 9.46 & 9.30 & \\
\hline $2 \mathrm{H}-4,141$ & 11.91 & 13.33 & 0.79141 & 18.9 & 0.78155 & 22.91 & 64.57 & 1.01 & 1.10 & -1.50 & 0.826 & 7.72 & 9.50 & \\
\hline $2 \mathrm{H}-5,1$ & 12.01 & 13.43 & 0.79671 & 18.9 & 0.78591 & 22.91 & 64.08 & 1.00 & 1.24 & -1.57 & 0.826 & 9.66 & 8.73 & \\
\hline $2 \mathrm{H}-5,11$ & 12.11 & 13.53 & 0.80200 & 18.9 & 0.79027 & 22.92 & 50.80 & 0.75 & 1.03 & -0.74 & 0.777 & 12.41 & 11.70 & \\
\hline $2 \mathrm{H}-5,21$ & 12.21 & 13.63 & 0.80729 & 18.9 & 0.79464 & 22.91 & 54.76 & 0.84 & 1.21 & -0.38 & 0.812 & 9.69 & 10.80 & \\
\hline $2 \mathrm{H}-5,31$ & 12.31 & 13.73 & 0.81259 & 18.9 & 0.79900 & 15.00 & 53.35 & 0.78 & 1.32 & -0.75 & 0.777 & 11.02 & 9.80 & \\
\hline $2 \mathrm{H}-5,41$ & 12.41 & 13.83 & 0.81788 & 18.9 & 0.80567 & 15.00 & 48.03 & 0.76 & 1.16 & -0.63 & 0.841 & 7.14 & 8.60 & \\
\hline $2 \mathrm{H}-5,51$ & 12.51 & 13.93 & 0.82318 & 18.9 & 0.81233 & 15.00 & 57.91 & 0.89 & 1.44 & -0.74 & 0.812 & 7.45 & 7.70 & \\
\hline $2 \mathrm{H}-5,61$ & 12.61 & 14.03 & 0.82847 & 18.9 & 0.81900 & 13.16 & 65.11 & 1.05 & 1.24 & -1.18 & 0.855 & 11.29 & 7.40 & \\
\hline $2 \mathrm{H}-5,71$ & 12.71 & 14.13 & 0.83377 & 18.9 & 0.82660 & 13.16 & 58.50 & 0.96 & 1.23 & -1.06 & 0.869 & 10.58 & 7.37 & \\
\hline $2 \mathrm{H}-5,81$ & 12.81 & 14.23 & 0.83906 & 18.9 & 0.83420 & 13.70 & 51.56 & 0.82 & 1.45 & -0.96 & 0.841 & 6.61 & 8.80 & \\
\hline $2 \mathrm{H}-5,91$ & 12.91 & 14.33 & 0.84435 & 18.9 & 0.84150 & 14.29 & 60.93 & 0.95 & 1.45 & -1.03 & 0.826 & 8.58 & 8.73 & \\
\hline $2 \mathrm{H}-5,101$ & 13.01 & 14.43 & 0.84965 & 18.9 & 0.84850 & 14.29 & 56.60 & 0.88 & 1.29 & -1.52 & 0.826 & 3.37 & 9.10 & \\
\hline $2 \mathrm{H}-5,111$ & 13.11 & 14.53 & 0.85494 & 18.9 & 0.85550 & 18.75 & 58.94 & 0.95 & 1.52 & -1.72 & 0.855 & 5.05 & 11.60 & \\
\hline $2 \mathrm{H}-5,121$ & 13.21 & 14.63 & 0.86024 & 18.9 & 0.86083 & 27.27 & 64.39 & 0.99 & 1.37 & -1.62 & 0.812 & 4.55 & 10.63 & \\
\hline $2 \mathrm{H}-5,131$ & 13.31 & 14.73 & 0.86553 & 18.9 & 0.86450 & 27.27 & 57.31 & 0.88 & 1.17 & -1.68 & 0.812 & 4.91 & 11.40 & \\
\hline $2 \mathrm{H}-6,1$ & 13.51 & 14.93 & 0.87612 & 18.9 & 0.87183 & 27.27 & 72.36 & 1.22 & 1.47 & -1.12 & 0.895 & 4.14 & 6.66 & \\
\hline $2 \mathrm{H}-6,11$ & 13.61 & 15.03 & 0.88141 & 18.9 & 0.87550 & 27.27 & 71.49 & 1.16 & 1.58 & -1.30 & 0.862 & 5.66 & 6.47 & \\
\hline $2 \mathrm{H}-6,21$ & 13.71 & 15.13 & 0.88671 & 18.9 & 0.87917 & 18.50 & 65.04 & 1.07 & 1.64 & -1.79 & 0.869 & 4.25 & 6.90 & \\
\hline $2 \mathrm{H}-6,31$ & 13.81 & 15.23 & 0.89200 & 18.9 & 0.88457 & 14.00 & 66.38 & 1.05 & 1.63 & -1.69 & 0.841 & 8.80 & 9.17 & \\
\hline $2 \mathrm{H}-6,41$ & 13.91 & 15.33 & 0.89729 & 18.9 & 0.89171 & 14.00 & 72.12 & 1.24 & 1.67 & -1.34 & 0.912 & 4.45 & 6.60 & \\
\hline $2 \mathrm{H}-6,51$ & 14.01 & 15.43 & 0.90259 & 18.9 & 0.89886 & 14.00 & 71.05 & 1.19 & 1.84 & -1.29 & 0.883 & 5.75 & 6.20 & \\
\hline $2 \mathrm{H}-6,61$ & 14.11 & 15.53 & 0.90788 & 18.9 & 0.90600 & 12.50 & 63.91 & 1.04 & 1.89 & -1.56 & 0.862 & 7.82 & 9.27 & \\
\hline $2 \mathrm{H}-6,71$ & 14.21 & 15.63 & 0.91350 & 17.8 & 0.91400 & 12.50 & 57.59 & 0.88 & 1.62 & -1.40 & 0.855 & 7.27 & 12.30 & \\
\hline $2 \mathrm{H}-6,81$ & 14.31 & 15.73 & 0.91933 & 17.1 & 0.92200 & 8.33 & 66.65 & 0.98 & 1.79 & -1.43 & 0.855 & 7.73 & 8.70 & \\
\hline $2 \mathrm{H}-6,91$ & 14.41 & 15.83 & 0.92517 & 17.1 & 0.93400 & 8.33 & 65.58 & 0.93 & 1.60 & -1.54 & 0.826 & 8.01 & 8.50 & \\
\hline $2 \mathrm{H}-6,101$ & 14.51 & 15.93 & 0.93100 & 17.1 & 0.94600 & 21.05 & 63.49 & 0.85 & 1.77 & -1.58 & 0.784 & 12.95 & 7.40 & \\
\hline $2 \mathrm{H}-6,111$ & 14.61 & 16.03 & 0.93683 & 17.1 & 0.95075 & 21.05 & 65.05 & 0.95 & 1.33 & -1.59 & 0.848 & 14.78 & 5.40 & \\
\hline $2 \mathrm{H}-6,121$ & 14.71 & 16.13 & 0.94267 & 17.1 & 0.95550 & 21.05 & 71.51 & 0.98 & 1.58 & -1.29 & 0.798 & 10.49 & 4.47 & \\
\hline $2 \mathrm{H}-6,131$ & 14.81 & 16.23 & 0.94850 & 17.1 & 0.96025 & 21.05 & 73.04 & 0.97 & 1.35 & -1.13 & 0.777 & 11.45 & 3.87 & \\
\hline $2 \mathrm{H}-6,141$ & 14.91 & 16.33 & 0.95433 & 17.1 & 0.96500 & 25.00 & 71.40 & 1.03 & 1.18 & -1.25 & 0.841 & 13.66 & 4.00 & \\
\hline $2 \mathrm{H}-7,1$ & 15.01 & 16.43 & 0.96017 & 17.1 & 0.96900 & 25.00 & 57.22 & 0.81 & 1.37 & -1.31 & 0.826 & 8.81 & 8.13 & \\
\hline $2 \mathrm{H}-7,11$ & 15.11 & 16.53 & 0.96600 & 17.1 & 0.97300 & 25.00 & 57.32 & 0.85 & 1.40 & -1.46 & 0.869 & 7.39 & 11.67 & \\
\hline
\end{tabular}




\begin{tabular}{|c|c|c|c|c|c|c|c|c|c|c|c|c|c|c|}
\hline $2 \mathrm{H}-7,21$ & 15.21 & 16.63 & 0.97183 & 17.1 & 0.97700 & 25.00 & 58.29 & 0.80 & 1.46 & -1.69 & 0.798 & 7.10 & 8.60 & \\
\hline $2 \mathrm{H}-7,31$ & 15.31 & 16.73 & 0.97767 & 17.1 & 0.98100 & 25.00 & 57.56 & 0.74 & 1.37 & -1.66 & 0.755 & 8.54 & 9.77 & \\
\hline $2 \mathrm{H}-7,4 \mathrm{I}$ & 15.41 & 16.83 & 0.98361 & 16.8 & 0.98500 & 13.13 & 64.97 & 0.93 & 1.46 & -1.51 & 0.855 & 14.65 & 6.67 & \\
\hline $2 \mathrm{H}-7,51$ & 15.51 & 16.93 & 0.98963 & 16.6 & 0.99262 & 13.13 & 61.43 & 0.78 & 1.49 & -1.62 & 0.762 & 11.46 & 6.40 & \\
\hline $2 \mathrm{H}-7,61$ & 15.61 & 17.03 & 0.99565 & 16.6 & 1.00023 & 13.13 & 60.23 & 0.82 & 1.47 & -1.62 & 0.819 & 11.95 & 7.50 & \\
\hline $2 \mathrm{H}-7,71$ & 15.71 & 17.13 & 1.00166 & 16.6 & & & 63.41 & 0.83 & 1.48 & -1.22 & 0.784 & 13.13 & 7.57 & \\
\hline $2 \mathrm{H}-\mathrm{CC}, 1$ & 15.78 & 17.20 & 1.00588 & 16.6 & & & 65.96 & 0.89 & 1.77 & -1.51 & 0.812 & 13.02 & 6.20 & \\
\hline \multicolumn{15}{|l|}{ 1-758B- } \\
\hline $2 \mathrm{H}-5,21$ & 15.71 & 17.21 & 1.00648 & 16.7 & & & 63.96 & 0.84 & 1.34 & -1.40 & 0.784 & 13.63 & 6.00 & \\
\hline $2 \mathrm{H}-5,31$ & 15.81 & 17.31 & 1.01250 & 16.6 & & & 67.40 & 0.90 & 1.09 & -1.35 & 0.805 & 18.57 & 6.07 & \\
\hline $2 \mathrm{H}-5,41$ & 15.91 & 17.41 & 1.01851 & 16.6 & & & 54.76 & 0.73 & 1.25 & -1.15 & 0.798 & 13.03 & 9.77 & \\
\hline $2 \mathrm{H}-5,51$ & 16.01 & 17.51 & 1.02453 & 16.6 & & & 59.97 & 0.78 & 1.19 & -1.44 & 0.784 & 12.42 & 9.00 & \\
\hline $2 \mathrm{H}-5,61$ & 16.11 & 17.61 & 1.03055 & 16.6 & & & 57.46 & 0.80 & 1.58 & -1.34 & 0.841 & 9.49 & 9.40 & \\
\hline $2 \mathrm{H}-5,71$ & 16.21 & 17.71 & 1.03657 & 16.6 & & & 65.09 & 0.86 & 1.39 & -1.32 & 0.798 & 9.45 & 5.37 & \\
\hline \multicolumn{15}{|l|}{$21-758 \mathrm{~A}-$} \\
\hline $3 \mathrm{H}-1,21$ & 15.81 & 17.72 & 1.03717 & 16.7 & & & 62.43 & 0.84 & 1.41 & -1.40 & 0.812 & 8.13 & 5.00 & \\
\hline $3 \mathrm{H}-1,31$ & 15.91 & 17.82 & 1.04319 & 16.6 & & & 57.61 & 0.74 & 1.66 & -1.55 & 0.777 & 9.17 & 4.50 & \\
\hline $3 \mathrm{H}-1,41$ & 16.01 & 17.92 & 1.04920 & 16.6 & & & 62.07 & 0.78 & 1.26 & -1.51 & 0.755 & 13.10 & 3.67 & \\
\hline $3 \mathrm{H}-1,51$ & 16.11 & 18.02 & 1.05522 & 16.6 & & & 64.56 & 0.87 & 1.51 & -1.45 & 0.812 & 14.85 & 4.50 & \\
\hline $3 \mathrm{H}-1,61$ & 16.21 & 18.12 & 1.06124 & 16.6 & & & 55.09 & 0.70 & 1.37 & -1.55 & 0.769 & 15.89 & 10.97 & \\
\hline $3 \mathrm{H}-1,71$ & 16.31 & 18.22 & 1.06726 & 16.6 & & & 63.84 & 0.79 & 1.51 & -1.15 & 0.741 & 18.95 & 5.20 & \\
\hline $3 \mathrm{H}-1,81$ & 16.41 & 18.32 & 1.07327 & 16.6 & & & 64.24 & 0.84 & 1.44 & -1.14 & 0.784 & 18.13 & 4.60 & \\
\hline $3 \mathrm{H}-1,91$ & 16.51 & 18.42 & 1.07929 & 16.6 & & & 58.08 & 0.81 & 1.54 & -1.37 & 0.841 & 15.85 & 6.13 & \\
\hline $3 \mathrm{H}-1,101$ & 16.61 & 18.52 & 1.08531 & 16.6 & & & 59.86 & 0.79 & 1.61 & -1.29 & 0.798 & 14.46 & 5.93 & \\
\hline $3 \mathrm{H}-1,111$ & 16.71 & 18.62 & 1.09133 & 16.6 & & & 58.53 & 0.78 & 1.39 & -1.25 & 0.798 & 7.86 & 5.90 & \\
\hline $3 \mathrm{H}-1,121$ & 16.81 & 18.72 & 1.09735 & 16.6 & & & 60.29 & 0.81 & 1.41 & -1.65 & 0.812 & 10.66 & 4.23 & \\
\hline $3 \mathrm{H}-1,131$ & 16.91 & 18.82 & 1.10336 & 16.6 & & & 65.42 & 0.85 & 1.46 & -1.36 & 0.777 & 13.73 & 2.33 & \\
\hline $3 \mathrm{H}-1,141$ & 17.01 & 18.92 & 1.10938 & 16.6 & & & 58.57 & 0.71 & 1.18 & -1.21 & 0.734 & 17.46 & 4.60 & \\
\hline $3 \mathrm{H}-2,1$ & 17.11 & 19.02 & 1.11540 & 16.6 & & & 51.56 & 0.68 & 1.23 & -0.88 & 0.791 & 10.35 & 7.03 & \\
\hline $3 \mathrm{H}-2,11$ & 17.21 & 19.12 & 1.12142 & 16.6 & & & 53.66 & 0.72 & 1.39 & -0.73 & 0.805 & 10.97 & 9.97 & \\
\hline $3 \mathrm{H}-2,21$ & 17.31 & 19.22 & 1.12743 & 16.6 & & & 56.82 & 0.82 & 1.46 & -1.32 & 0.869 & 11.97 & 9.50 & \\
\hline $3 \mathrm{H}-2,31$ & 17.41 & 19.32 & 1.13345 & 16.6 & & & 59.69 & 0.80 & 1.57 & -1.26 & 0.805 & 10.24 & 9.03 & \\
\hline $3 \mathrm{H}-2,41$ & 17.51 & 19.42 & 1.13947 & 16.6 & & & 63.90 & 0.83 & 1.68 & -1.37 & 0.784 & 11.56 & 8.57 & \\
\hline $3 \mathrm{H}-2,51$ & 17.61 & 19.52 & 1.14549 & 16.6 & & & 61.54 & 0.79 & 1.76 & -1.84 & 0.777 & 14.29 & 8.20 & \\
\hline $3 \mathrm{H}-2,61$ & 17.71 & 19.62 & 1.15150 & 16.6 & & & 60.12 & 0.83 & 1.39 & -1.12 & 0.826 & 12.16 & 8.07 & \\
\hline $3 \mathrm{H}-2,71$ & 17.81 & 19.72 & 1.15752 & 16.6 & & & 58.51 & 0.76 & 1.43 & -1.07 & 0.784 & 16.05 & 9.37 & \\
\hline $3 \mathrm{H}-2,81$ & 17.91 & 19.82 & 1.16354 & 16.6 & & & 49.49 & 0.70 & 1.51 & -1.04 & 0.848 & 11.49 & 11.20 & \\
\hline $3 \mathrm{H}-2,91$ & 18.01 & 19.92 & 1.16956 & 16.6 & & & 61.82 & 0.83 & 1.72 & -1.21 & 0.812 & 7.19 & 7.63 & \\
\hline $3 \mathrm{H}-2,101$ & 18.11 & 20.02 & 1.17558 & 16.6 & & & 61.92 & 0.84 & 1.79 & -1.64 & 0.812 & 11.00 & 7.37 & \\
\hline $3 \mathrm{H}-2,111$ & 18.21 & 20.12 & 1.18159 & 16.6 & & & 65.22 & 0.82 & 1.44 & -1.64 & 0.755 & 14.72 & 4.30 & \\
\hline $3 \mathrm{H}-2,121$ & 18.31 & 20.22 & 1.18761 & 16.6 & & & 64.48 & 0.85 & 1.39 & -1.32 & 0.798 & 15.65 & 4.17 & \\
\hline $3 \mathrm{H}-2,131$ & 18.41 & 20.32 & 1.19363 & 16.6 & & & 62.36 & 0.83 & 1.50 & -1.50 & 0.798 & 12.69 & 4.43 & \\
\hline $3 \mathrm{H}-2,141$ & 18.51 & 20.42 & 1.19965 & 16.6 & & & 57.17 & 0.81 & 1.54 & -1.47 & 0.855 & 8.04 & 8.20 & \\
\hline $3 \mathrm{H}-3,1$ & 18.61 & 20.52 & 1.20566 & 16.6 & & & 60.22 & 0.84 & 1.83 & -1.07 & 0.838 & 5.82 & 7.20 & \\
\hline $3 \mathrm{H}-3,11$ & 18.71 & 20.62 & 1.21168 & 16.6 & & & 56.85 & 0.77 & 1.90 & -1.59 & 0.819 & 5.73 & 10.80 & \\
\hline $3 \mathrm{H}-3,21$ & 18.81 & 20.72 & 1.21770 & 16.6 & & & 60.19 & 0.84 & 1.56 & -1.82 & 0.841 & 9.11 & 9.40 & \\
\hline $3 \mathrm{H}-3,31$ & 18.91 & 20.82 & 1.22372 & 16.6 & & & 64.99 & 0.88 & 1.56 & -1.36 & 0.819 & 9.54 & 7.23 & \\
\hline $3 \mathrm{H}-3,41$ & 19.01 & 20.92 & 1.22973 & 16.6 & & & 66.84 & 0.87 & 1.57 & -1.39 & 0.784 & 8.81 & 6.97 & \\
\hline $3 \mathrm{H}-3,51$ & 19.11 & 21.02 & 1.23575 & 16.6 & & & 61.05 & 0.80 & 1.54 & -1.30 & 0.784 & 10.82 & 8.00 & \\
\hline $3 \mathrm{H}-3,61$ & 19.21 & 21.12 & 1.24177 & 16.6 & & & 60.66 & 0.77 & 1.68 & -1.27 & 0.762 & 6.24 & 9.83 & \\
\hline $3 \mathrm{H}-3,71$ & 19.31 & 21.22 & 1.24779 & 16.6 & & & 60.20 & 0.80 & 1.79 & -1.45 & 0.798 & 9.64 & 7.60 & \\
\hline $3 \mathrm{H}-3,81$ & 19.41 & 21.32 & 1.25381 & 16.6 & & & 63.63 & 0.86 & 1.75 & -1.41 & 0.812 & 8.90 & 8.20 & \\
\hline $3 \mathrm{H}-3,91$ & 19.51 & 21.42 & 1.25982 & 16.6 & & & 62.33 & 0.81 & 1.81 & -1.70 & 0.784 & 9.25 & 9.37 & \\
\hline $3 \mathrm{H}-3,101$ & 19.61 & 21.52 & 1.26584 & 16.6 & & & 59.22 & 0.77 & 1.61 & -1.50 & 0.784 & 8.88 & 9.20 & \\
\hline $3 \mathrm{H}-3,111$ & 19.71 & 21.62 & 1.27186 & 16.6 & & & 56.15 & 0.70 & 1.25 & -1.61 & 0.748 & 11.17 & 6.60 & \\
\hline $3 \mathrm{H}-3,121$ & 19.81 & 21.72 & 1.27788 & 16.6 & & & 31.20 & 0.41 & 1.33 & -1.44 & 0.784 & 5.64 & 12.40 & Ash F, and below \\
\hline $3 \mathrm{H}-3,131$ & 19.91 & 21.82 & 1.28389 & 16.6 & & & 56.60 & 0.79 & 1.20 & -1.59 & 0.841 & 10.16 & 12.73 & \\
\hline $3 \mathrm{H}-3,141$ & 20.01 & 21.92 & 1.28991 & 16.6 & & & 61.11 & 0.80 & 1.41 & -1.27 & 0.784 & 8.17 & 8.40 & \\
\hline $3 \mathrm{H}-4,1$ & 20.11 & 22.02 & 1.29593 & 16.6 & & & 58.22 & 0.83 & 1.78 & -1.60 & 0.855 & 9.05 & 8.87 & \\
\hline $3 \mathrm{H}-4,11$ & 20.21 & 22.12 & 1.30195 & 16.6 & & & 61.41 & 0.88 & 1.81 & -2.17 & 0.862 & 9.87 & 9.20 & \\
\hline
\end{tabular}




\begin{tabular}{|c|c|c|c|c|c|c|c|c|c|c|c|c|c|c|}
\hline $\begin{array}{l}\text { Core, section, } \\
\text { interval }(\mathrm{cm})\end{array}$ & $\begin{array}{l}\text { ODP } \\
\text { depth } \\
\text { (mbsf) }\end{array}$ & $\begin{array}{c}\text { Composite } \\
\text { depth } \\
\text { (m) }\end{array}$ & $\begin{array}{c}\text { Magnetic } \\
\text { age } \\
\text { (m.y.) }\end{array}$ & $\begin{array}{c}\text { Magnetic } \\
\text { sedimentation } \\
\text { rate } \\
(\mathrm{m} / \mathrm{m} . \mathrm{y} .) \\
\end{array}$ & $\begin{array}{c}\delta^{18} \mathrm{O} \\
\text { age } \\
\text { (m.y.) }\end{array}$ & $\begin{array}{c}\delta^{18} \mathrm{O} \\
\text { sedimentation } \\
\text { rate } \\
(\mathrm{m} / \mathrm{m} \cdot \mathrm{y} .) \\
\end{array}$ & $\begin{array}{c}\text { Mean } \\
\left(\mathrm{wt} \% \mathrm{CaCO}_{3}\right)\end{array}$ & $\begin{array}{c}\text { Magnetic } \\
\mathrm{CaCO}_{3} \mathrm{MAR} \\
\left(\mathrm{g} / \mathrm{cm}^{2} / \mathrm{k} . \mathrm{y} .\right)\end{array}$ & $\begin{array}{l}\delta^{13} \mathrm{C} \\
\%_{00} \text { to } \\
\text { (PDB) }\end{array}$ & $\begin{array}{l}\delta^{18} \mathrm{O} \\
\%_{0} \text { to } \\
\text { (PDB) }\end{array}$ & $\begin{array}{c}\text { Dry-bulk } \\
\text { density } \\
\left(\mathrm{g} / \mathrm{cm}^{3}\right)\end{array}$ & $\begin{array}{c}\text { Coarse } \\
\text { fraction } \\
\text { (wt } \%>150 \mu \mathrm{m} \text { ) }\end{array}$ & $\begin{array}{c}\text { Interpolated MS } \\
\text { K (10-6) } \\
\text { (cgs) }\end{array}$ & Comment \\
\hline \multicolumn{15}{|l|}{ 121-758A-(Cont.) } \\
\hline $3 \mathrm{H}-4,2 \mathrm{I}$ & 20.31 & 22.22 & 1.30796 & 16.6 & & & 67.38 & 0.89 & 1.55 & -1.82 & 0.798 & 10.32 & 5.60 & \\
\hline $3 \mathrm{H}-4,31$ & 20.41 & 22.32 & 1.31398 & 16.6 & & & 58.06 & 0.78 & 1.26 & -1.89 & 0.805 & 11.63 & 5.37 & \\
\hline $3 \mathrm{H}-4,41$ & 20.51 & 22.42 & 1.32000 & 16.6 & & & 55.77 & 0.70 & 1.19 & -1.46 & 0.755 & 14.56 & 5.63 & \\
\hline $3 \mathrm{H}-4,51$ & 20.61 & 22.52 & 1.32602 & 16.6 & & & 61.14 & 0.90 & 1.63 & -1.15 & 0.883 & 9.52 & 6.20 & \\
\hline $3 \mathrm{H}-4,61$ & 20.71 & 22.62 & 1.33204 & 16.6 & & & 57.12 & 0.77 & 1.83 & -1.38 & 0.812 & 9.41 & 6.87 & \\
\hline $3 \mathrm{H}-4,71$ & 20.81 & 22.72 & 1.33805 & 16.6 & & & 62.18 & 0.94 & 1.79 & -1.55 & 0.912 & 7.61 & 7.03 & \\
\hline $3 \mathrm{H}-4,81$ & 20.91 & 22.82 & 1.34407 & 16.6 & & & 63.64 & 0.90 & 1.97 & -2.18 & 0.855 & 8.59 & 7.10 & \\
\hline $3 \mathrm{H}-4,91$ & 21.01 & 22.92 & 1.35009 & 16.6 & & & 68.93 & 0.96 & 1.74 & -1.68 & 0.841 & 9.57 & 7.10 & \\
\hline $3 \mathrm{H}-4,101$ & 21.11 & 23.02 & 1.35611 & 16.6 & & & 61.21 & 0.84 & 1.78 & -1.63 & 0.826 & 12.23 & 8.47 & \\
\hline $3 \mathrm{H}-4,111$ & 21.21 & 23.12 & 1.36212 & 16.6 & & & 62.70 & 0.85 & 1.68 & -1.30 & 0.812 & 11.61 & 7.60 & \\
\hline $3 \mathrm{H}-4,121$ & 21.31 & 23.22 & 1.36814 & 16.6 & & & 64.15 & 0.85 & 1.76 & -1.22 & 0.798 & 10.67 & 6.27 & \\
\hline $3 \mathrm{H}-4,131$ & 21.41 & 23.32 & 1.37416 & 16.6 & & & 63.22 & 0.88 & 1.80 & -1.52 & 0.834 & 9.70 & 6.30 & \\
\hline $3 \mathrm{H}-4,141$ & 21.51 & 23.42 & 1.38018 & 16.6 & & & 59.85 & 0.82 & 2.09 & -1.61 & 0.826 & 11.97 & 8.50 & \\
\hline $3 \mathrm{H}-5,1$ & 21.61 & 23.52 & 1.38619 & 16.6 & & & 66.09 & 0.93 & 1.96 & -1.79 & 0.849 & 16.10 & 4.17 & \\
\hline $3 \mathrm{H}-5,11$ & 21.71 & 23.62 & 1.39221 & 16.6 & & & 65.05 & 0.87 & 1.47 & -1.64 & 0.805 & 14.72 & 6.37 & \\
\hline $3 \mathrm{H}-5,2 \mathrm{I}$ & 21.81 & 23.72 & 1.39823 & 16.6 & & & 58.88 & 0.79 & 1.32 & -1.47 & 0.812 & 16.03 & 7.10 & \\
\hline $3 \mathrm{H}-5,31$ & 21.91 & 23.82 & 1.40425 & 16.6 & & & 60.36 & 0.84 & 1.68 & -1.30 & 0.841 & 11.58 & 7.07 & \\
\hline $3 \mathrm{H}-5,41$ & 22.01 & 23.92 & 1.41027 & 16.6 & & & 61.87 & 0.89 & 1.84 & -1.35 & 0.869 & 10.37 & 9.07 & \\
\hline $3 \mathrm{H}-5,51$ & 22.11 & 24.02 & 1.41628 & 16.6 & & & 61.10 & 0.87 & 1.95 & -1.59 & 0.855 & 7.10 & 8.80 & \\
\hline $3 \mathrm{H}-5,61$ & 22.21 & 24.12 & 1.42230 & 16.6 & & & 65.16 & 0.91 & 1.90 & -1.47 & 0.841 & 8.38 & 6.43 & \\
\hline $3 \mathrm{H}-5,71$ & 22.31 & 24.22 & 1.42832 & 16.6 & & & 64.04 & 0.94 & 1.82 & -1.68 & 0.883 & 10.62 & 6.77 & \\
\hline $3 \mathrm{H}-5,81$ & 22.41 & 24.32 & 1.43434 & 16.6 & & & 61.29 & 0.87 & 1.82 & -1.84 & 0.855 & 12.02 & 5.60 & \\
\hline $3 \mathrm{H}-5,91$ & 22.51 & 24.42 & 1.44035 & 16.6 & & & 62.85 & 0.89 & 1.77 & -1.41 & 0.855 & 12.71 & 4.20 & \\
\hline $3 \mathrm{H}-5,101$ & 22.61 & 24.52 & 1.44637 & 16.6 & & & 63.81 & 0.89 & 1.73 & -1.28 & 0.841 & 9.37 & 4.77 & \\
\hline $3 \mathrm{H}-5,111$ & 22.71 & 24.62 & 1.45239 & 16.6 & & & 63.85 & 0.94 & 1.80 & -1.52 & 0.883 & 9.07 & 5.40 & \\
\hline $3 \mathrm{H}-5,121$ & 22.81 & 24.72 & 1.45841 & 16.6 & & & 62.62 & 0.83 & 1.72 & -1.67 & 0.798 & 9.14 & 6.21 & \\
\hline $3 \mathrm{H}-6,1$ & 23.11 & 25.02 & 1.47646 & 16.6 & & & 65.69 & 0.91 & 2.01 & -1.79 & 0.831 & 11.85 & 6.39 & \\
\hline $3 \mathrm{H}-6,11$ & 23.21 & 25.12 & 1.48248 & 16.6 & & & 64.11 & 0.93 & 1.81 & -1.45 & 0.869 & 8.30 & 7.00 & \\
\hline $3 \mathrm{H}-6,21$ & 23.31 & 25.22 & 1.48850 & 16.6 & & & 63.98 & 0.91 & 1.85 & -1.60 & 0.855 & 12.31 & 7.60 & \\
\hline $3 \mathrm{H}-6,31$ & 23.41 & 25.32 & 1.49451 & 16.6 & & & 58.15 & 0.85 & 2.08 & -1.88 & 0.876 & 12.39 & 8.43 & \\
\hline $3 \mathrm{H}-6,41$ & 23.51 & 25.42 & 1.50053 & 16.6 & & & 66.40 & 0.91 & 2.08 & -1.31 & 0.826 & 9.94 & 7.20 & \\
\hline $3 \mathrm{H}-6,51$ & 23.61 & 25.52 & 1.50655 & 16.6 & & & 63.71 & 0.89 & 1.98 & -1.69 & 0.841 & 11.07 & 8.50 & \\
\hline $3 \mathrm{H}-6,61$ & 23.71 & 25.62 & 1.51257 & 16.6 & & & 61.54 & 0.83 & 1.94 & -1.75 & 0.812 & 14.12 & 6.70 & \\
\hline $3 \mathrm{H}-6,71$ & 23.81 & 25.72 & 1.51858 & 16.6 & & & 59.44 & 0.83 & 1.65 & -1.30 & 0.841 & 9.51 & 7.70 & \\
\hline $3 \mathrm{H}-6,81$ & 23.91 & 25.82 & 1.52460 & 16.6 & & & 60.69 & 0.86 & 1.79 & -1.25 & 0.855 & 12.72 & 5.20 & \\
\hline $3 \mathrm{H}-6,91$ & 24.01 & 25.92 & 1.53062 & 16.6 & & & 62.78 & 0.89 & 1.74 & -1.32 & 0.855 & 12.49 & 4.30 & \\
\hline $3 \mathrm{H}-6,101$ & 24.11 & 26.02 & 1.53664 & 16.6 & & & 49.17 & 0.67 & 1.50 & -1.39 & 0.826 & 7.33 & 7.37 & \\
\hline $3 \mathrm{H}-6,111$ & 24.21 & 26.12 & 1.54265 & 16.6 & & & 59.04 & 0.85 & 1.72 & -1.50 & 0.869 & 8.03 & 7.50 & \\
\hline $3 \mathrm{H}-6,121$ & 24.31 & 26.22 & 1.54867 & 16.6 & & & 67.30 & 1.02 & 1.49 & -1.62 & 0.912 & 10.50 & 6.50 & \\
\hline $3 \mathrm{H}-6,131$ & 24.41 & 26.32 & 1.55469 & 16.6 & & & 67.68 & 0.85 & 1.54 & -1.73 & 0.755 & 12.40 & 6.43 & \\
\hline $3 \mathrm{H}-6,141$ & 24.51 & 26.42 & 1.56071 & 16.6 & & & 62.31 & 0.84 & 1.35 & -1.62 & 0.812 & 13.76 & 11.00 & \\
\hline $3 \mathrm{H}-7,1$ & 24.61 & 26.52 & 1.56673 & 16.6 & & & 61.32 & 0.85 & 1.42 & -1.43 & 0.834 & 13.58 & 6.87 & \\
\hline $3 \mathrm{H}-7,11$ & 24.71 & 26.62 & 1.57274 & 16.6 & & & 56.60 & 0.76 & 1.06 & -1.41 & 0.812 & 11.63 & 7.57 & \\
\hline $3 \mathrm{H}-7,21$ & 24.81 & 26.72 & 1.57876 & 16.6 & & & 61.51 & 0.88 & 1.45 & -1.36 & 0.862 & 11.56 & 6.20 & \\
\hline $3 \mathrm{H}-7,31$ & 24.91 & 26.82 & 1.58478 & 16.6 & & & 61.69 & 0.84 & 1.41 & -1.41 & 0.819 & 12.13 & 7.30 & \\
\hline $3 \mathrm{H}-7,41$ & 25.01 & 26.92 & 1.59080 & 16.6 & & & 66.43 & 0.87 & 1.45 & -1.74 & 0.784 & 14.07 & 6.93 & \\
\hline $3 \mathrm{H}-7,51$ & 25.11 & 27.02 & 1.59681 & 16.6 & & & 63.49 & 0.87 & 1.42 & -1.39 & 0.826 & 9.60 & 7.20 & \\
\hline $3 \mathrm{H}-7,61$ & 25.21 & 27.12 & 1.60283 & 16.6 & & & 64.24 & 0.97 & 1.77 & -1.47 & 0.912 & 8.73 & 6.25 & \\
\hline \multicolumn{15}{|l|}{$121-758 \mathrm{~B}-$} \\
\hline $3 \mathrm{H}-3,141$ & 23.31 & 27.13 & 1.60343 & 16.7 & & & 64.63 & 0.91 & 1.62 & -1.36 & 0.841 & 9.11 & 5.90 & \\
\hline $3 \mathrm{H}-4,1$ & 23.41 & 27.23 & 1.60945 & 16.6 & & & 61.54 & 0.93 & 1.62 & -1.50 & 0.912 & 10.60 & 6.40 & \\
\hline $3 \mathrm{H}-4,11$ & 23.51 & 27.33 & 1.61547 & 16.6 & & & 60.24 & 0.82 & 1.30 & -1.73 & 0.819 & 13.16 & 7.93 & \\
\hline $3 \mathrm{H}-4,2 \mathrm{I}$ & 23.61 & 27.43 & 1.62149 & 16.6 & & & 59.22 & 0.84 & 1.41 & -1.15 & 0.855 & 8.06 & 9.40 & \\
\hline
\end{tabular}




\begin{tabular}{|c|c|c|c|c|}
\hline $3 \mathrm{H}-4,31$ & 23.71 & 27.53 & 1.62750 & 16.6 \\
\hline $3 \mathrm{H}-4,41$ & 23.81 & 27.63 & 1.63352 & 16.6 \\
\hline $3 \mathrm{H}-4,51$ & 23.91 & 27.73 & 1.63954 & 16.6 \\
\hline $3 \mathrm{H}-4,73$ & 24.13 & 27.95 & 1.65278 & 16.6 \\
\hline $3 \mathrm{H}-4,81$ & 24.21 & 28.03 & 1.65759 & 16.6 \\
\hline $3 \mathrm{H}-4,91$ & 24.31 & 28.13 & 1.66584 & 12.1 \\
\hline $3 H-4,101$ & 24.41 & 28.23 & 1.67558 & 10.3 \\
\hline $3 \mathrm{H}-4,111$ & 24.51 & 28.33 & 1.68531 & 10.3 \\
\hline $3 \mathrm{H}-4,12 \mathrm{I}$ & 24.61 & 28.43 & 1.69504 & 10.3 \\
\hline $3 \mathrm{H}-4,131$ & 24.71 & 28.53 & 1.70478 & 10.3 \\
\hline $3 \mathrm{H}-4,14 \mathrm{I}$ & 24.81 & 28.63 & 1.71451 & 10.3 \\
\hline $3 \mathrm{H}-5,1$ & 24.91 & 28.73 & 1.72425 & 10.3 \\
\hline $3 \mathrm{H}-5,11$ & 25.01 & 28.83 & 1.73398 & 10.3 \\
\hline $3 \mathrm{H}-5,21$ & 25.11 & 28.93 & 1.74372 & 10.3 \\
\hline $3 \mathrm{H}-5,31$ & 25.21 & 29.03 & 1.75345 & 10.3 \\
\hline $3 \mathrm{H}-5,41$ & 25.31 & 29.13 & 1.76319 & 10.3 \\
\hline $3 \mathrm{H}-5,51$ & 25.41 & 29.23 & 1.77292 & 10.3 \\
\hline $3 \mathrm{H}-5,61$ & 25.51 & 29.33 & 1.78265 & 10.3 \\
\hline $3 \mathrm{H}-5,7 \mathrm{I}$ & 25.61 & 29.43 & 1.79239 & 10.3 \\
\hline $3 \mathrm{H}-5,81$ & 25.71 & 29.53 & 1.80212 & 10.3 \\
\hline \multicolumn{5}{|l|}{$1-758 \mathrm{~A}-$} \\
\hline $4 \mathrm{H}-1,1$ & 25.21 & 29.54 & 1.80310 & 10.2 \\
\hline $4 \mathrm{H}-1,11$ & 25.31 & 29.64 & 1.81283 & 10.3 \\
\hline $4 \mathrm{H}-1,21$ & 25.41 & 29.74 & 1.82257 & 10.3 \\
\hline $4 \mathrm{H}-1,31$ & 25.51 & 29.84 & 1.83230 & 10.3 \\
\hline $4 \mathrm{H}-1,41$ & 25.61 & 29.94 & 1.84204 & 10.3 \\
\hline $4 \mathrm{H}-1,51$ & 25.71 & 30.04 & 1.85177 & 10.3 \\
\hline $4 \mathrm{H}-1,61$ & 25.81 & 30.14 & 1.86150 & 10.3 \\
\hline $4 \mathrm{H}-1,71$ & 25.91 & 30.24 & 1.87124 & 10.3 \\
\hline $4 \mathrm{H}-1,81$ & 26.01 & 30.34 & 1.88072 & 10.5 \\
\hline $4 \mathrm{H}-1,91$ & 26.11 & 30.44 & 1.88791 & 13.9 \\
\hline $4 \mathrm{H}-1,101$ & 26.21 & 30.54 & 1.89511 & 13.9 \\
\hline $4 \mathrm{H}-1,111$ & 26.31 & 30.64 & 1.90230 & 13.9 \\
\hline $4 \mathrm{H}-1,121$ & 26.41 & 30.74 & 1.90950 & 13.9 \\
\hline $4 \mathrm{H}-1,131$ & 26.51 & 30.84 & 1.91670 & 13.9 \\
\hline $4 \mathrm{H}-1,141$ & 26.61 & 30.94 & 1.92389 & 13.9 \\
\hline $4 \mathrm{H}-2,1$ & 26.71 & 31.04 & 1.93109 & 13.9 \\
\hline $4 \mathrm{H}-2,11$ & 26.81 & 31.14 & 1.93828 & 13.9 \\
\hline $4 \mathrm{H}-2,21$ & 26.91 & 31.24 & 1.94548 & 13.9 \\
\hline $4 \mathrm{H}-2,31$ & 27.01 & 31.34 & 1.95267 & 13.9 \\
\hline $4 \mathrm{H}-2,41$ & 27.11 & 31.44 & 1.95987 & 13.9 \\
\hline $4 \mathrm{H}-2,51$ & 27.21 & 31.54 & 1.96706 & 13.9 \\
\hline $4 \mathrm{H}-2,61$ & 27.31 & 31.64 & 1.97426 & 13.9 \\
\hline $4 \mathrm{H}-2,71$ & 27.41 & 31.74 & 1.98145 & 13.9 \\
\hline $4 \mathrm{H}-2,81$ & 27.51 & 31.84 & 1.98865 & 13.9 \\
\hline $4 \mathrm{H}-2,91$ & 27.61 & 31.94 & 1.99584 & 13.9 \\
\hline $4 \mathrm{H}-2,101$ & 27.71 & 32.04 & 2.00304 & 13.9 \\
\hline $4 \mathrm{H}-2,111$ & 27.81 & 32.14 & 2.01023 & 13.9 \\
\hline $4 \mathrm{H}-2,121$ & 27.91 & 32.24 & 2.01743 & 13.9 \\
\hline $4 \mathrm{H}-2,131$ & 28.01 & 32.34 & 2.02462 & 13.9 \\
\hline $4 \mathrm{H}-2,141$ & 28.11 & 32.44 & 2.03182 & 13.9 \\
\hline $4 \mathrm{H}-3,1$ & 28.21 & 32.54 & 2.03901 & 13.9 \\
\hline $4 \mathrm{H}-3,11$ & 28.31 & 32.64 & 2.04621 & 13.9 \\
\hline $4 \mathrm{H}-3,21$ & 28.41 & 32.74 & 2.05340 & 13.9 \\
\hline $4 \mathrm{H}-3,31$ & 28.51 & 32.84 & 2.06060 & 13.9 \\
\hline $4 \mathrm{H}-3,41$ & 28.61 & 32.94 & 2.06779 & 13.9 \\
\hline $4 \mathrm{H}-3,51$ & 28.71 & 33.04 & 2.07499 & 13.9 \\
\hline $4 \mathrm{H}-3,61$ & 28.81 & 33.14 & 2.08218 & 13.9 \\
\hline $4 \mathrm{H}-3,71$ & 28.91 & 33.24 & 2.08938 & 13.9 \\
\hline $4 \mathrm{H}-3,81$ & 29.01 & 33.34 & 2.09657 & 13.9 \\
\hline $4 \mathrm{H}-3,91$ & 29.11 & 33.44 & 2.10377 & 13.9 \\
\hline $4 \mathrm{H}-3,101$ & 29.21 & 33.54 & 2.11096 & 13.9 \\
\hline
\end{tabular}

\begin{tabular}{|c|c|c|c|c|c|c|}
\hline 60.81 & 0.79 & 1.29 & -1.45 & 0.784 & 7.84 & 9.27 \\
\hline 53.93 & 0.74 & 1.47 & -1.28 & 0.826 & & 12.23 \\
\hline 55.08 & 0.74 & 1.80 & -1.34 & 0.812 & 8.49 & 12.10 \\
\hline 66.21 & 0.92 & 1.57 & -1.29 & 0.841 & 8.75 & 38.40 \\
\hline 62.79 & 0.92 & 1.37 & -1.45 & 0.883 & 10.73 & 10.80 \\
\hline 62.44 & 0.69 & 1.44 & -1.65 & 0.912 & 10.44 & 8.13 \\
\hline 64.18 & 0.54 & 1.51 & -1.66 & 0.812 & 14.27 & 6.93 \\
\hline 61.37 & 0.53 & 1.54 & -1.22 & 0.841 & 10.88 & 6.80 \\
\hline 65.67 & 0.64 & 1.49 & -1.38 & 0.955 & 8.76 & 8.00 \\
\hline 60.71 & 0.54 & 1.61 & -1.49 & 0.869 & 6.21 & 10.60 \\
\hline 64.96 & 0.62 & 1.65 & -1.38 & 0.926 & 9.25 & 8.40 \\
\hline 61.92 & 0.55 & 1.59 & -1.62 & 0.872 & 10.04 & 6.87 \\
\hline 57.02 & 0.52 & 1.45 & -1.07 & 0.883 & 6.95 & 8.10 \\
\hline 58.70 & 0.54 & 1.62 & -1.38 & 0.898 & 6.62 & 8.30 \\
\hline 59.82 & 0.56 & 1.55 & -1.77 & 0.905 & 7.99 & 8.87 \\
\hline 59.51 & 0.53 & 1.55 & -1.32 & 0.869 & 6.21 & 8.50 \\
\hline 56.86 & 0.51 & 1.58 & -1.47 & 0.869 & 6.29 & 9.60 \\
\hline 57.48 & 0.50 & 1.31 & -1.82 & 0.841 & 10.50 & 19.27 \\
\hline 60.25 & 0.52 & 1.40 & -1.89 & 0.841 & 11.55 & 10.73 \\
\hline 62.31 & 0.55 & 1.51 & -1.68 & 0.855 & 13.46 & 6.10 \\
\hline 62.51 & 0.49 & 1.64 & -1.67 & 0.771 & 10.35 & 5.73 \\
\hline 58.52 & 0.47 & 1.62 & -1.39 & 0.784 & 10.48 & 6.00 \\
\hline 57.88 & 0.47 & 1.10 & -1.48 & 0.784 & 9.62 & 5.00 \\
\hline 59.82 & 0.48 & 1.93 & -1.52 & 0.784 & 8.32 & 6.03 \\
\hline 66.20 & 0.59 & 1.70 & -1.50 & 0.869 & 8.91 & 4.20 \\
\hline 68.42 & 0.66 & 1.47 & -1.32 & 0.940 & 11.26 & 4.70 \\
\hline 67.20 & 0.58 & 1.54 & -1.33 & 0.834 & 8.14 & 7.53 \\
\hline 59.82 & 0.56 & 1.76 & -1.85 & 0.912 & 11.33 & 10.73 \\
\hline 57.80 & 0.52 & 1.37 & -1.46 & 0.855 & 8.36 & 5.20 \\
\hline 59.81 & 0.71 & 1.63 & -1.49 & 0.855 & 8.21 & 5.37 \\
\hline 66.98 & 0.80 & 1.65 & -1.88 & 0.855 & 10.92 & 4.10 \\
\hline 62.89 & 0.79 & 1.46 & -1.40 & 0.898 & 8.23 & 3.90 \\
\hline 63.77 & 0.81 & 1.60 & -1.55 & 0.912 & 11.29 & 3.73 \\
\hline 68.64 & 0.85 & 2.01 & -1.44 & 0.890 & 7.44 & 2.13 \\
\hline 66.08 & 0.80 & 1.92 & -1.92 & 0.869 & 8.36 & 1.70 \\
\hline 66.19 & 0.80 & 1.81 & -1.68 & 0.865 & 12.01 & 3.23 \\
\hline 64.74 & 0.78 & 1.85 & -1.65 & 0.869 & 12.17 & 4.73 \\
\hline 65.11 & 0.77 & 1.80 & -1.63 & 0.855 & 9.88 & 3.60 \\
\hline 66.19 & 0.81 & 1.72 & -1.37 & 0.883 & 12.52 & 3.73 \\
\hline 67.37 & 0.79 & 1.55 & -1.42 & 0.841 & 12.20 & 3.17 \\
\hline 61.02 & 0.71 & 1.40 & -1.12 & 0.834 & 10.09 & 4.30 \\
\hline 63.82 & 0.80 & 1.60 & -1.48 & 0.898 & 13.88 & 4.60 \\
\hline 63.68 & 0.71 & 1.65 & -1.32 & 0.798 & 12.01 & 5.20 \\
\hline 63.62 & 0.76 & 1.58 & -1.48 & 0.855 & 7.56 & 5.10 \\
\hline 64.25 & 0.81 & 1.81 & -1.53 & 0.912 & 9.45 & 3.97 \\
\hline 63.60 & 0.77 & 1.60 & -1.53 & 0.869 & 7.65 & 3.47 \\
\hline 62.81 & 0.77 & 1.64 & -1.58 & 0.876 & 6.18 & 4.60 \\
\hline 62.10 & 0.74 & 1.64 & -1.38 & 0.855 & 8.35 & 3.30 \\
\hline 60.82 & 0.81 & 1.65 & -1.22 & 0.955 & 5.31 & 3.47 \\
\hline 63.39 & 0.78 & 1.53 & -1.66 & 0.883 & 10.95 & 3.00 \\
\hline 66.84 & 0.86 & 1.56 & -0.99 & 0.926 & 8.74 & 3.70 \\
\hline 68.26 & 0.85 & 1.57 & -1.19 & 0.898 & 8.67 & 4.07 \\
\hline 64.84 & 0.82 & 1.50 & -1.23 & 0.912 & 8.52 & 4.00 \\
\hline 65.47 & 0.88 & 1.66 & -1.36 & 0.969 & 11.09 & 4.50 \\
\hline 68.96 & 0.85 & 1.80 & -1.45 & 0.883 & 9.80 & 4.50 \\
\hline 71.76 & 0.92 & 1.73 & -1.59 & 0.926 & 8.11 & 3.90 \\
\hline 71.24 & 0.88 & 1.73 & -1.90 & 0.890 & 10.87 & 3.97 \\
\hline 71.02 & 0.90 & 1.87 & -2.21 & 0.912 & 7.49 & 3.33 \\
\hline 70.38 & 0.91 & 1.69 & -1.39 & 0.926 & 9.30 & 3.90 \\
\hline 69.93 & 0.91 & 1.76 & -1.42 & 0.940 & 7.11 & 3.80 \\
\hline 62.53 & 0.81 & 1.68 & -1.52 & 0.926 & 5.12 & 4.1 \\
\hline
\end{tabular}




\begin{tabular}{|c|c|c|c|c|c|c|c|c|c|c|c|c|c|c|}
\hline $\begin{array}{l}\text { Core, section, } \\
\text { interval }(\mathrm{cm})\end{array}$ & $\begin{array}{l}\text { ODP } \\
\text { depth } \\
\text { (mbsf) }\end{array}$ & $\begin{array}{l}\text { Composite } \\
\text { depth } \\
\text { (m) }\end{array}$ & $\begin{array}{l}\text { Magnetic } \\
\text { age } \\
\text { (m.y.) }\end{array}$ & $\begin{array}{l}\text { Magnetic } \\
\text { sedimentation } \\
\text { rate } \\
(\mathrm{m} / \mathrm{m} . \mathrm{y} .)\end{array}$ & $\begin{array}{l}\delta^{18} \mathrm{O} \\
\text { age } \\
\text { (m.y.) }\end{array}$ & $\begin{array}{c}\delta^{18} \mathrm{O} \\
\text { sedimentation } \\
\text { rate } \\
(\mathrm{m} / \mathrm{m} . \mathrm{y} .)\end{array}$ & $\stackrel{\text { Mean }}{\text { (wt } \% \mathrm{CaCO}_{3} \text { ) }}$ & $\begin{array}{c}\text { Magnetic } \\
\mathrm{CaCO}_{3} \text { MAR } \\
\left(\mathrm{g} / \mathrm{cm}^{2} / \text { k.y. }\right)\end{array}$ & $\begin{array}{l}\delta^{13} \mathrm{C} \\
\%_{0} \text { to } \\
\text { (PDB) }\end{array}$ & $\begin{array}{l}\delta^{18} \mathrm{O} \\
\%_{00} \text { to } \\
\text { (PDB) }\end{array}$ & $\begin{array}{c}\text { Dry-bulk } \\
\text { density } \\
\left(\mathrm{g} / \mathrm{cm}^{3}\right)\end{array}$ & $\begin{array}{c}\text { Coarse } \\
\text { fraction } \\
(\mathrm{wt} \%>150 \mu \mathrm{m})\end{array}$ & $\begin{array}{l}\text { Interpolated MS } \\
\text { K (10-6) } \\
\text { (cgs) }\end{array}$ & Comment \\
\hline \multicolumn{15}{|l|}{ 121-758A-(Cont.) } \\
\hline $4 \mathrm{H}-3,111$ & 29.31 & 33.64 & 2.11816 & 13.9 & & & 65.27 & 0.82 & 1.61 & -1.97 & 0.905 & 8.86 & 4.70 & \\
\hline $4 \mathrm{H}-3,121$ & 29.41 & 33.74 & 2.12535 & 13.9 & & & 67.12 & 0.86 & 1.81 & -1.62 & 0.926 & 6.41 & 4.63 & \\
\hline $4 \mathrm{H}-3,131$ & 29.51 & 33.84 & 2.13255 & 13.9 & & & 68.03 & 0.83 & 1.59 & -1.67 & 0.883 & 8.45 & 4.83 & \\
\hline $4 \mathrm{H}-3,141$ & 29.61 & 33.94 & 2.13974 & 13.9 & & & 70.92 & 0.97 & 1.32 & -1.42 & 0.983 & 9.73 & 3.80 & \\
\hline $4 \mathrm{H}-4,1$ & 29.71 & 34.04 & 2.14694 & 13.9 & & & 69.07 & 0.97 & 1.60 & -1.32 & 1.016 & 4.62 & 3.93 & \\
\hline $4 \mathrm{H}-4,11$ & 29.81 & 34.14 & 2.15413 & 13.9 & & & 67.63 & 0.88 & 1.94 & -2.14 & 0.933 & 7.04 & 4.80 & \\
\hline $4 \mathrm{H}-4,21$ & 29.91 & 34.24 & 2.16133 & 13.9 & & & 69.54 & 0.88 & 1.81 & -1.75 & 0.912 & 10.11 & 4.50 & \\
\hline $4 \mathrm{H}-4,31$ & 30.01 & 34.34 & 2.16852 & 13.9 & & & 65.05 & 0.76 & 1.55 & -1.82 & 0.841 & 8.78 & 5.73 & \\
\hline $4 \mathrm{H}-4,41$ & 30.11 & 34.44 & 2.17572 & 13.9 & & & 61.45 & 0.77 & 1.58 & -1.57 & 0.898 & 10.11 & 5.53 & \\
\hline $4 \mathrm{H}-4,51$ & 30.21 & 34.54 & 2.18291 & 13.9 & & & 63.42 & 0.87 & 1.64 & -1.54 & 0.983 & 5.59 & 5.00 & \\
\hline $4 \mathrm{H}-4,61$ & 30.31 & 34.64 & 2.19011 & 13.9 & & & 61.75 & 0.80 & 1.76 & -1.67 & 0.933 & 5.14 & 5.47 & \\
\hline $4 H-4,71$ & 30.41 & 34.74 & 2.19730 & 13.9 & & & 59.18 & 0.77 & 1.54 & -1.79 & 0.940 & 4.85 & 4.60 & \\
\hline $4 \mathrm{H}-4,81$ & 30.51 & 34.84 & 2.20450 & 13.9 & & & 58.94 & 0.78 & 1.78 & -1.66 & 0.955 & 6.86 & 4.50 & \\
\hline $4 \mathrm{H}-4,91$ & 30.61 & 34.94 & 2.21170 & 13.9 & & & 68.12 & 0.90 & 1.57 & -1.69 & 0.955 & 7.75 & 5.63 & \\
\hline $4 \mathrm{H}-4,101$ & 30.71 & 35.04 & 2.21889 & 13.9 & & & 67.23 & 0.91 & 1.58 & -1.66 & 0.969 & 4.77 & 6.33 & \\
\hline $4 \mathrm{H}-4,111$ & 30.81 & 35.14 & 2.22609 & 13.9 & & & 67.03 & 0.87 & 1.69 & -1.88 & 0.933 & 5.87 & 6.80 & \\
\hline $4 \mathrm{H}-4,121$ & 30.91 & 35.24 & 2.23328 & 13.9 & & & 65.68 & 0.86 & 1.60 & -1.53 & 0.940 & 6.39 & 6.27 & \\
\hline $4 \mathrm{H}-4,131$ & 31.01 & 35.34 & 2.24048 & 13.9 & & & 67.01 & 0.84 & 1.63 & -1.28 & 0.905 & 6.91 & 4.57 & \\
\hline $4 \mathrm{H}-4,141$ & 31.11 & 35.44 & 2.24767 & 13.9 & & & 57.04 & 0.72 & 1.76 & -1.31 & 0.912 & 7.29 & 4.50 & Ash $\mathrm{H}$, and below \\
\hline $4 \mathrm{H}-5,7$ & 31.27 & 35.60 & 2.25918 & 13.9 & & & 61.74 & 0.83 & 1.85 & -1.56 & 0.969 & 5.93 & 16.83 & \\
\hline $4 \mathrm{H}-5,11$ & 31.31 & 35.64 & 2.26206 & 13.9 & & & 56.65 & 0.76 & 1.85 & -1.71 & 0.962 & 4.09 & 8.10 & \\
\hline $4 \mathrm{H}-5,21$ & 31.41 & 35.74 & 2.26926 & 13.9 & & & 67.51 & 0.86 & 1.83 & -1.84 & 0.912 & 6.54 & 5.30 & \\
\hline $4 \mathrm{H}-5,31$ & 31.51 & 35.84 & 2.27645 & 13.9 & & & 67.66 & 0.87 & 1.91 & -1.72 & 0.926 & 6.18 & 4.63 & \\
\hline $4 \mathrm{H}-5,41$ & 31.61 & 35.94 & 2.28365 & 13.9 & & & 70.18 & 0.93 & 2.18 & -1.61 & 0.955 & 6.40 & 4.03 & \\
\hline $4 \mathrm{H}-5,51$ & 31.71 & 36.04 & 2.29084 & 13.9 & & & 72.06 & 0.93 & 1.94 & -1.50 & 0.926 & 10.87 & 3.70 & \\
\hline $4 \mathrm{H}-5,61$ & 31.81 & 36.14 & 2.29804 & 13.9 & & & 75.28 & 0.94 & 1.84 & -1.84 & 0.898 & 14.40 & 3.63 & \\
\hline $4 \mathrm{H}-5,71$ & 31.91 & 36.24 & 2.30523 & 13.9 & & & 70.74 & 0.85 & 1.79 & -1.62 & 0.869 & 15.03 & 3.53 & \\
\hline $4 \mathrm{H}-5,81$ & 32.01 & 36.34 & 2.31243 & 13.9 & & & 70.82 & 0.93 & 1.63 & -1.47 & 0.947 & 13.92 & 4.10 & \\
\hline $4 \mathrm{H}-5,91$ & 32.11 & 36.44 & 2.31962 & 13.9 & & & 71.96 & 0.91 & 1.75 & -1.39 & 0.912 & 12.89 & 3.47 & \\
\hline $4 \mathrm{H}-5,101$ & 32.21 & 36.54 & 2.32682 & 13.9 & & & 69.39 & 0.85 & 1.61 & -1.50 & 0.883 & 11.76 & 4.43 & \\
\hline $4 \mathrm{H}-5,111$ & 32.31 & 36.64 & 2.33401 & 13.9 & & & 67.54 & 0.86 & 1.54 & -1.49 & 0.912 & 10.24 & 4.40 & \\
\hline $4 \mathrm{H}-5,121$ & 32.41 & 36.74 & 2.34121 & 13.9 & & & 71.91 & 0.81 & 1.72 & -1.62 & 0.812 & 11.23 & 3.60 & \\
\hline $4 \mathrm{H}-5,131$ & 32.51 & 36.84 & 2.34840 & 13.9 & & & 74.68 & 0.92 & 1.82 & -1.85 & 0.890 & 14.76 & 3.30 & \\
\hline $4 \mathrm{H}-5,14 \mathrm{I}$ & 32.61 & 36.94 & 2.35560 & 13.9 & & & 71.04 & 0.81 & 1.63 & -1.94 & 0.826 & 15.54 & 3.30 & \\
\hline $4 \mathrm{H}-6,1$ & 32.71 & 37.04 & 2.36279 & 13.9 & & & 64.54 & 0.79 & 1.40 & -1.61 & 0.876 & 13.92 & 3.33 & \\
\hline $4 \mathrm{H}-6,11$ & 32.81 & 37.14 & 2.36999 & 13.9 & & & 65.13 & 0.82 & 1.55 & -1.03 & 0.905 & 8.48 & 4.40 & \\
\hline $4 \mathrm{H}-6,2 \mathrm{I}$ & 32.91 & 37.24 & 2.37718 & 13.9 & & & 64.24 & 0.84 & 1.58 & -1.49 & 0.940 & 9.94 & 4.10 & \\
\hline $4 \mathrm{H}-6,31$ & 33.01 & 37.34 & 2.38438 & 13.9 & & & 67.08 & 0.78 & 1.74 & -1.88 & 0.834 & 14.22 & 4.03 & \\
\hline $4 \mathrm{H}-6,41$ & 33.11 & 37.44 & 2.39157 & 13.9 & & & 65.60 & 0.79 & 1.30 & -1.39 & 0.869 & 12.58 & 4.10 & \\
\hline $4 \mathrm{H}-6,51$ & 33.21 & 37.54 & 2.39877 & 13.9 & & & 63.69 & 0.78 & 1.26 & -1.16 & 0.883 & 12.34 & 4.30 & \\
\hline $4 \mathrm{H}-6,61$ & 33.31 & 37.64 & 2.40596 & 13.9 & & & 60.45 & 0.76 & 1.39 & -1.46 & 0.905 & 9.12 & 5.37 & \\
\hline $4 \mathrm{H}-6,71$ & 33.41 & 37.74 & 2.41316 & 13.9 & & & 59.99 & 0.81 & 1.35 & -1.25 & 0.969 & 6.98 & 4.90 & \\
\hline $4 \mathrm{H}-6,81$ & 33.51 & 37.84 & 2.42035 & 13.9 & & & 59.48 & 0.79 & 1.30 & -1.87 & 0.955 & 2.41 & 6.40 & \\
\hline $4 \mathrm{H}-6,91$ & 33.61 & 37.94 & 2.42755 & 13.9 & & & 60.41 & 0.77 & 1.75 & -1.74 & 0.912 & 5.82 & 4.03 & \\
\hline $4 \mathrm{H}-6,101$ & 33.71 & 38.04 & 2.43474 & 13.9 & & & 64.54 & 0.79 & 1.69 & -1.59 & 0.883 & 5.24 & 4.17 & \\
\hline $4 \mathrm{H}-6,111$ & 33.81 & 38.14 & 2.44194 & 13.9 & & & 60.71 & 0.79 & 1.45 & -1.65 & 0.940 & 3.26 & 5.50 & \\
\hline $4 \mathrm{H}-6,121$ & 33.91 & 38.24 & 2.44913 & 13.9 & & & 66.59 & 0.87 & 1.73 & -1.87 & 0.940 & 4.47 & 4.27 & \\
\hline $4 \mathrm{H}-6,131$ & 34.01 & 38.34 & 2.45633 & 13.9 & & & 67.24 & 0.86 & 1.58 & -1.67 & 0.919 & 4.60 & 3.63 & \\
\hline $4 \mathrm{H}-6,141$ & 34.11 & 38.44 & 2.46352 & 13.9 & & & 66.84 & 0.81 & 1.73 & -2.16 & 0.869 & 9.99 & 3.60 & \\
\hline $4 \mathrm{H}-7,1$ & 34.21 & 38.54 & 2.47074 & 13.9 & & & 69.73 & 0.87 & 1.33 & -1.70 & 0.898 & 12.74 & 3.07 & \\
\hline $4 \mathrm{H}-7,11$ & 34.31 & 38.64 & 2.47809 & 13.6 & & & 68.39 & 0.87 & 1.45 & -1.49 & 0.940 & 9.08 & 4.27 & \\
\hline $4 \mathrm{H}-7,21$ & 34.41 & 38.74 & 2.48544 & 13.6 & & & 61.47 & 0.80 & 1.48 & -1.33 & 0.955 & 2.29 & 5.20 & \\
\hline $4 \mathrm{H}-7,31$ & 34.51 & 38.84 & 2.49279 & 13.6 & & & 68.01 & 0.84 & 1.78 & -1.68 & 0.912 & 4.52 & 3.83 & \\
\hline $4 \mathrm{H}-7,41$ & 34.61 & 38.94 & 2.50015 & 13.6 & & & 67.28 & 0.82 & 1.57 & -1.54 & 0.898 & 5.33 & 3.53 & \\
\hline
\end{tabular}




\begin{tabular}{|c|c|c|c|c|c|c|c|c|c|c|c|}
\hline $4 \mathrm{H}-7,51$ & 34.71 & 39.04 & 2.50750 & 13.6 & 67.72 & 0.87 & 1.60 & -1.97 & 0.940 & 5.83 & 3.50 \\
\hline $4 \mathrm{H}-7,61$ & 34.81 & 39.14 & 2.51485 & 13.6 & 64.80 & 0.80 & 1.76 & -2.05 & 0.912 & 8.26 & 3.57 \\
\hline $4 \mathrm{H}-7,71$ & 34.91 & 39.24 & 2.52221 & 13.6 & 68.05 & 0.92 & 1.64 & -1.62 & 0.997 & 4.96 & 3.85 \\
\hline \multicolumn{12}{|l|}{$121-758 \mathrm{~B}-$} \\
\hline $4 \mathrm{H}-5,101$ & 35.41 & 39.25 & 2.52294 & 13.7 & 64.06 & 0.83 & & & 0.940 & 5.30 & 3.98 \\
\hline $4 \mathrm{H}-5,111$ & 35.51 & 39.35 & 2.53029 & 13.6 & 61.53 & 0.81 & & & 0.969 & 2.52 & 5.20 \\
\hline $4 \mathrm{H}-5,121$ & 35.61 & 39.45 & 2.53765 & 13.6 & 61.04 & 0.72 & & & 0.869 & 3.73 & 4.17 \\
\hline $4 \mathrm{H}-5,131$ & 35.71 & 39.55 & 2.54500 & 13.6 & 67.95 & 0.80 & & & 0.869 & 5.40 & 3.23 \\
\hline $4 \mathrm{H}-5,141$ & 35.81 & 39.65 & 2.55235 & 13.6 & 64.71 & 0.79 & & & 0.898 & 5.56 & 3.60 \\
\hline $4 \mathrm{H}-6,1$ & 35.91 & 39.75 & 2.55971 & 13.6 & 68.03 & 0.81 & & & 0.876 & 8.28 & 3.60 \\
\hline $4 \mathrm{H}-6,11$ & 36.01 & 39.85 & 2.56706 & 13.6 & 66.15 & 0.83 & & & 0.926 & 5.31 & 4.20 \\
\hline $4 \mathrm{H}-6,21$ & 36.11 & 39.95 & 2.57441 & 13.6 & 67.84 & 0.89 & & & 0.969 & 4.34 & 4.30 \\
\hline $4 \mathrm{H}-6,31$ & 36.21 & 40.05 & 2.58176 & 13.6 & 71.13 & 0.92 & & & 0.947 & 8.40 & 3.63 \\
\hline $4 \mathrm{H}-6,41$ & 36.31 & 40.15 & 2.58912 & 13.6 & 70.62 & 0.85 & & & 0.883 & 8.83 & 3.40 \\
\hline \multicolumn{12}{|l|}{$121-758 \mathrm{~A}-$} \\
\hline $5 \mathrm{H}-1,21$ & 35.01 & 40.16 & 2.58985 & 13.7 & 71.26 & 0.88 & & & 0.898 & 9.65 & 3.40 \\
\hline $5 \mathrm{H}-1,31$ & 35.11 & 40.26 & 2.59721 & 13.6 & 66.28 & 0.80 & & & 0.890 & 5.77 & 4.73 \\
\hline $5 \mathrm{H}-1,41$ & 35.21 & 40.36 & 2.60456 & 13.6 & 68.42 & 0.85 & & & 0.912 & 5.20 & 4.50 \\
\hline $5 \mathrm{H}-1,51$ & 35.31 & 40.46 & 2.61191 & 13.6 & 71.88 & 0.91 & & & 0.926 & 4.60 & 4.30 \\
\hline $5 \mathrm{H}-1,61$ & 35.41 & 40.56 & 2.61926 & 13.6 & 70.53 & 0.90 & & & 0.933 & 5.62 & 3.77 \\
\hline $5 \mathrm{H}-1,71$ & 35.51 & 40.66 & 2.62662 & 13.6 & 70.13 & 0.90 & & & 0.940 & 6.27 & 3.63 \\
\hline $5 \mathrm{H}-1,81$ & 35.61 & 40.76 & 2.63397 & 13.6 & 72.51 & 0.93 & & & 0.940 & 7.88 & 4.00 \\
\hline $5 \mathrm{H}-1,91$ & 35.71 & 40.86 & 2.64132 & 13.6 & 68.43 & 0.73 & & & 0.784 & 5.12 & 4.27 \\
\hline $5 \mathrm{H}-1,101$ & 35.81 & 40.96 & 2.64868 & 13.6 & 68.20 & 0.83 & & & 0.898 & 4.47 & 4.33 \\
\hline $5 \mathrm{H}-1,111$ & 35.91 & 41.06 & 2.65603 & 13.6 & 71.99 & 0.87 & & & 0.890 & 6.71 & 3.80 \\
\hline $5 \mathrm{H}-1,121$ & 36.01 & 41.16 & 2.66338 & 13.6 & 69.32 & 0.83 & & & 0.883 & 8.12 & 3.63 \\
\hline $5 \mathrm{H}-1,131$ & 36.11 & 41.26 & 2.67074 & 13.6 & 71.25 & 0.82 & & & 0.848 & 7.85 & 3.70 \\
\hline $5 \mathrm{H}-1,141$ & 36.21 & 41.36 & 2.67809 & 13.6 & 69.99 & 0.83 & & & 0.869 & 5.98 & 3.80 \\
\hline $5 \mathrm{H}-2,1$ & 36.31 & 41.46 & 2.68544 & 13.6 & 70.82 & 0.81 & & & 0.841 & 6.30 & 4.20 \\
\hline $5 \mathrm{H}-2,11$ & 36.41 & 41.56 & 2.69279 & 13.6 & 69.58 & 0.86 & & & 0.912 & 4.74 & 5.23 \\
\hline $5 \mathrm{H}-2,21$ & 36.51 & 41.66 & 2.70015 & 13.6 & 67.60 & 0.82 & & & 0.898 & 5.42 & 5.80 \\
\hline $5 \mathrm{H}-2,31$ & 36.61 & 41.76 & 2.70750 & 13.6 & 67.44 & 0.82 & & & 0.898 & 6.53 & 5.47 \\
\hline $5 \mathrm{H}-2,41$ & 36.71 & 41.86 & 2.71485 & 13.6 & 66.33 & 0.84 & & & 0.926 & 5.22 & 5.03 \\
\hline $5 \mathrm{H}-2,51$ & 36.81 & 41.96 & 2.72221 & 13.6 & 67.86 & 0.81 & & & 0.883 & 3.95 & 5.70 \\
\hline $5 \mathrm{H}-2,61$ & 36.91 & 42.06 & 2.72956 & 13.6 & 63.67 & 0.74 & & & 0.855 & 5.50 & 6.70 \\
\hline $5 \mathrm{H}-2,71$ & 37.01 & 42.16 & 2.73691 & 13.6 & 56.05 & 0.65 & & & 0.855 & 4.66 & 10.57 \\
\hline $5 \mathrm{H}-2,81$ & 37.11 & 42.26 & 2.74426 & 13.6 & 64.13 & 0.73 & & & 0.834 & 5.42 & 8.00 \\
\hline $5 \mathrm{H}-2,91$ & 37.21 & 42.36 & 2.75162 & 13.6 & 64.11 & 0.76 & & & 0.869 & 4.56 & 7.37 \\
\hline $5 \mathrm{H}-2,101$ & 37.31 & 42.46 & 2.75897 & 13.6 & 63.93 & 0.74 & & & 0.855 & 6.57 & 7.37 \\
\hline $5 \mathrm{H}-2,111$ & 37.41 & 42.56 & 2.76632 & 13.6 & 63.30 & 0.77 & & & 0.890 & 4.84 & 7.60 \\
\hline $5 \mathrm{H}-2,121$ & 37.51 & 42.66 & 2.77368 & 13.6 & 65.71 & 0.74 & & & 0.826 & 5.70 & 10.23 \\
\hline $5 \mathrm{H}-2,131$ & 37.61 & 42.76 & 2.78103 & 13.6 & 67.55 & 0.79 & & & 0.862 & 9.09 & 8.80 \\
\hline $5 \mathrm{H}-2,141$ & 37.71 & 42.86 & 2.78838 & 13.6 & 65.96 & 0.77 & & & 0.855 & 5.67 & 7.20 \\
\hline $5 \mathrm{H}-3,1$ & 37.81 & 42.96 & 2.79574 & 13.6 & 67.83 & 0.78 & & & 0.848 & 7.73 & 6.77 \\
\hline $5 \mathrm{H}-3,11$ & 37.91 & 43.06 & 2.80309 & 13.6 & 65.51 & 0.80 & & & 0.898 & 4.03 & 7.50 \\
\hline $5 \mathrm{H}-3,21$ & 38.01 & 43.16 & 2.81044 & 13.6 & 62.09 & 0.77 & & & 0.912 & 2.91 & 7.30 \\
\hline $5 \mathrm{H}-3,31$ & 38.11 & 43.26 & 2.81779 & 13.6 & 66.01 & 0.81 & & & 0.898 & 8.28 & 6.30 \\
\hline $5 \mathrm{H}-3,41$ & 38.21 & 43.36 & 2.82515 & 13.6 & 68.02 & 0.79 & & & 0.855 & 7.44 & 5.47 \\
\hline $5 \mathrm{H}-3,51$ & 38.31 & 43.46 & 2.83250 & 13.6 & 64.79 & 0.78 & & & 0.883 & 7.44 & 5.60 \\
\hline $5 \mathrm{H}-3,61$ & 38.41 & 43.56 & 2.83985 & 13.6 & 68.93 & 0.86 & & & 0.919 & 6.59 & 6.03 \\
\hline $5 \mathrm{H}-3,71$ & 38.51 & 43.66 & 2.84721 & 13.6 & 66.86 & 0.79 & & & 0.869 & 7.28 & 5.53 \\
\hline $5 \mathrm{H}-3,81$ & 38.61 & 43.76 & 2.85456 & 13.6 & 65.95 & 0.79 & & & 0.883 & 5.37 & 6.10 \\
\hline $5 \mathrm{H}-3,91$ & 38.71 & 43.86 & 2.86191 & 13.6 & 61.91 & 0.72 & & & 0.855 & 6.98 & 5.67 \\
\hline $5 \mathrm{H}-3,101$ & 38.81 & 43.96 & 2.86926 & 13.6 & 61.81 & 0.73 & & & 0.869 & 10.86 & 5.90 \\
\hline $5 \mathrm{H}-3,111$ & 38.91 & 44.06 & 2.87662 & 13.6 & 70.72 & 0.81 & & & 0.848 & 9.34 & 5.70 \\
\hline $5 \mathrm{H}-3,121$ & 39.01 & 44.16 & 2.88397 & 13.6 & 69.31 & 0.82 & & & 0.869 & 9.03 & 5.17 \\
\hline $5 \mathrm{H}-3,131$ & 39.11 & 44.26 & 2.89132 & 13.6 & 68.33 & 0.83 & & & 0.898 & 4.82 & 6.13 \\
\hline $5 \mathrm{H}-3,141$ & 39.21 & 44.36 & 2.89868 & 13.6 & 67.73 & 0.83 & & & 0.898 & 4.68 & 6.00 \\
\hline $5 \mathrm{H}-4,1$ & 39.31 & 44.46 & 2.90603 & 13.6 & 67.75 & 0.84 & & & 0.912 & 3.89 & 7.03 \\
\hline $5 \mathrm{H}-4,11$ & 39.41 & 44.56 & 2.91338 & 13.6 & 66.85 & 0.85 & & & 0.933 & 3.67 & 7.50 \\
\hline
\end{tabular}




\begin{tabular}{|c|c|c|c|c|c|c|c|c|c|c|c|c|c|c|}
\hline $\begin{array}{l}\text { Core, section, } \\
\text { interval }(\mathrm{cm})\end{array}$ & $\begin{array}{l}\text { ODP } \\
\text { depth } \\
\text { (mbsf) }\end{array}$ & $\begin{array}{c}\text { Composite } \\
\text { depth } \\
\text { (m) }\end{array}$ & $\begin{array}{c}\text { Magnetic } \\
\text { age } \\
\text { (m.y.) }\end{array}$ & $\begin{array}{c}\text { Magnetic } \\
\text { sedimentation } \\
\text { rate } \\
(\mathrm{m} / \mathrm{m} . \mathrm{y} .)\end{array}$ & $\begin{array}{l}\delta^{18} \mathrm{O} \\
\text { age } \\
(\mathrm{m} . \mathrm{y} .)\end{array}$ & $\begin{array}{c}\delta^{18} \mathrm{O} \\
\text { sedimentation } \\
\text { rate } \\
(\mathrm{m} / \mathrm{m} . \mathrm{y} .)\end{array}$ & $\begin{array}{c}\text { Mean } \\
\text { (wt \% } \mathrm{CaCO}_{3} \text { ) }\end{array}$ & $\begin{array}{c}\text { Magnetic } \\
\mathrm{CaCO}_{3} \text { MAR } \\
\left(\mathrm{g} / \mathrm{cm}^{2} / \mathrm{k} . \mathrm{y} .\right)\end{array}$ & $\begin{array}{l}\delta^{13} \mathrm{C} \\
\%_{00} \text { to } \\
\text { (PDB) }\end{array}$ & $\begin{array}{l}\delta^{18} \mathrm{O} \\
\%_{0} \text { to } \\
\text { (PDB) }\end{array}$ & $\begin{array}{c}\text { Dry-bulk } \\
\text { density } \\
\left(\mathrm{g} / \mathrm{cm}^{3}\right)\end{array}$ & $\begin{array}{c}\text { Coarse } \\
\text { fraction } \\
\text { (wt } \%>150 \mu \mathrm{m})\end{array}$ & $\begin{array}{c}\text { Interpolated MS } \\
\text { K (10-6) } \\
\text { (cgs) }\end{array}$ & Comment \\
\hline \multicolumn{15}{|l|}{ 121-758A-(Cont.) } \\
\hline $5 \mathrm{H}-4,21$ & 39.51 & 44.66 & 2.92070 & 13.7 & & & 66.59 & 0.78 & & & 0.855 & 4.77 & 8.00 & \\
\hline $5 \mathrm{H}-4,31$ & 39.61 & 44.76 & 2.92770 & 14.3 & & & 63.97 & 0.83 & & & 0.912 & 1.88 & 9.57 & \\
\hline $5 \mathrm{H}-4,41$ & 39.71 & 44.86 & 2.93470 & 14.3 & & & 68.06 & 0.86 & & & 0.883 & 3.71 & 8.33 & \\
\hline $5 \mathrm{H}-4,51$ & 39.81 & 44.96 & 2.94170 & 14.3 & & & 70.89 & 0.97 & & & 0.955 & 3.03 & 7.00 & \\
\hline $5 \mathrm{H}-4,61$ & 39.91 & 45.06 & 2.94870 & 14.3 & & & 71.42 & 0.92 & & & 0.905 & 3.93 & 6.50 & \\
\hline $5 \mathrm{H}-4,71$ & 40.01 & 45.16 & 2.95570 & 14.3 & & & 72.22 & 0.97 & & & 0.940 & 5.70 & 5.83 & \\
\hline $5 \mathrm{H}-4,81$ & 40.11 & 45.26 & 2.96270 & 14.3 & & & 69.90 & 0.92 & & & 0.926 & 9.53 & 5.40 & \\
\hline $5 \mathrm{H}-4,91$ & 40.21 & 45.36 & 2.96970 & 14.3 & & & 72.28 & 0.93 & & & 0.898 & 6.93 & 6.07 & \\
\hline $5 \mathrm{H}-4,101$ & 40.31 & 45.46 & 2.97670 & 14.3 & & & 72.16 & 0.93 & & & 0.898 & 8.06 & 6.00 & \\
\hline $5 \mathrm{H}-4,111$ & 40.41 & 45.56 & 2.98370 & 14.3 & & & 73.17 & 0.88 & & & 0.841 & 9.51 & 6.00 & \\
\hline $5 \mathrm{H}-4,121$ & 40.51 & 45.66 & 2.99064 & 14.4 & & & 74.92 & 0.91 & & & 0.841 & 10.68 & 5.40 & \\
\hline $5 \mathrm{H}-4,131$ & 40.61 & 45.76 & 2.99707 & 15.6 & & & 70.46 & 0.95 & & & 0.869 & 8.59 & 6.50 & \\
\hline $5 \mathrm{H}-4,14 \mathrm{I}$ & 40.71 & 45.86 & 3.00350 & 15.6 & & & 71.56 & 1.03 & & & 0.926 & 9.71 & 6.70 & \\
\hline $5 \mathrm{H}-5,1$ & 40.81 & 45.96 & 3.00993 & 15.6 & & & 68.93 & 1.05 & & & 0.983 & 7.88 & 6.50 & \\
\hline $5 \mathrm{H}-5,11$ & 40.91 & 46.06 & 3.01636 & 15.6 & & & 66.28 & 0.93 & & & 0.902 & 4.45 & 8.23 & \\
\hline $5 \mathrm{H}-5,21$ & 41.01 & 46.16 & 3.02279 & 15.6 & & & 65.96 & 0.95 & & & 0.926 & 4.61 & 8.00 & \\
\hline $5 \mathrm{H}-5,31$ & 41.11 & 46.26 & 3.02921 & 15.6 & & & 70.61 & 0.97 & & & 0.883 & 7.20 & 7.53 & \\
\hline $5 \mathrm{H}-5,4 \mathrm{I}$ & 41.21 & 46.36 & 3.03564 & 15.6 & & & 66.31 & 0.95 & & & 0.926 & 4.93 & 7.83 & \\
\hline $5 \mathrm{H}-5,51$ & 41.31 & 46.46 & 3.04207 & 15.6 & & & 66.44 & 0.93 & & & 0.898 & 5.77 & 8.00 & \\
\hline $5 \mathrm{H}-5,61$ & 41.41 & 46.56 & 3.04850 & 15.6 & & & 68.33 & 0.94 & & & 0.883 & 5.71 & 7.27 & \\
\hline $5 \mathrm{H}-5,71$ & 41.51 & 46.66 & 3.05493 & 15.6 & & & 64.60 & 0.93 & & & 0.926 & 6.76 & 8.40 & \\
\hline $5 \mathrm{H}-5,81$ & 41.61 & 46.76 & 3.06136 & 15.6 & & & 67.03 & 1.05 & & & 1.004 & 10.57 & 8.80 & \\
\hline $5 \mathrm{H}-5,91$ & 41.71 & 46.86 & 3.06779 & 15.6 & & & 64.66 & 0.86 & & & 0.855 & 5.63 & 7.60 & \\
\hline $5 \mathrm{H}-5,101$ & 41.81 & 46.96 & 3.07421 & 15.6 & & & 64.39 & 0.90 & & & 0.898 & 5.59 & 7.00 & \\
\hline $5 \mathrm{H}-5,111$ & 41.91 & 47.06 & 3.08095 & 14.8 & & & 63.21 & 0.83 & & & 0.883 & 4.50 & 7.80 & \\
\hline $5 \mathrm{H}-5,121$ & 42.01 & 47.16 & 3.09048 & 10.5 & & & 69.16 & 0.63 & & & 0.869 & 6.30 & 7.03 & \\
\hline $5 \mathrm{H}-5,131$ & 42.11 & 47.26 & 3.10000 & 10.5 & & & 69.96 & 0.63 & & & 0.862 & 8.55 & 6.30 & \\
\hline $5 \mathrm{H}-6,1$ & 42.31 & 47.46 & 3.11905 & 10.5 & & & 66.71 & 0.63 & & & 0.896 & 8.52 & 5.96 & \\
\hline $5 \mathrm{H}-6,11$ & 42.41 & 47.56 & 3.12857 & 10.5 & & & 69.16 & 0.66 & & & 0.905 & 10.65 & 4.53 & \\
\hline $5 \mathrm{H}-6,21$ & 42.51 & 47.66 & 3.13810 & 10.5 & & & 67.20 & 0.70 & & & 0.997 & 8.65 & 4.60 & \\
\hline $5 \mathrm{H}-6,31$ & 42.61 & 47.76 & 3.14762 & 10.5 & & & 62.96 & 0.62 & & & 0.933 & 6.70 & 5.60 & \\
\hline $5 \mathrm{H}-6,41$ & 42.71 & 47.86 & 3.15714 & 10.5 & & & 59.83 & 0.55 & & & 0.883 & 3.61 & 8.23 & \\
\hline $5 \mathrm{H}-6,51$ & 42.81 & 47.96 & 3.16667 & 10.5 & & & 63.57 & 0.73 & & & 1.097 & 2.32 & 10.00 & \\
\hline $5 \mathrm{H}-6,61$ & 42.91 & 48.06 & 3.17619 & 10.5 & & & 63.30 & 0.64 & & & 0.969 & 3.78 & 7.77 & \\
\hline $5 \mathrm{H}-6,71$ & 43.01 & 48.16 & 3.18411 & 12.6 & & & 63.69 & 0.71 & & & 0.883 & 4.77 & 7.23 & \\
\hline $5 \mathrm{H}-6,81$ & 43.11 & 48.26 & 3.19097 & 14.6 & & & 65.04 & 0.89 & & & 0.940 & 5.66 & 8.70 & \\
\hline $5 \mathrm{H}-6,91$ & 43.21 & 48.36 & 3.19782 & 14.6 & & & 62.77 & 0.86 & & & 0.940 & 4.85 & 9.07 & \\
\hline $5 \mathrm{H}-6,101$ & 43.31 & 48.46 & 3.20467 & 14.6 & & & 60.40 & 0.82 & & & 0.926 & 6.83 & 8.70 & \\
\hline $5 \mathrm{H}-6,111$ & 43.41 & 48.56 & 3.21153 & 14.6 & & & 62.46 & 0.83 & & & 0.912 & 6.08 & 8.20 & \\
\hline $5 \mathrm{H}-6,121$ & 43.51 & 48.66 & 3.21838 & 14.6 & & & 64.17 & 0.84 & & & 0.898 & 7.81 & 5.57 & \\
\hline $5 \mathrm{H}-6,131$ & 43.61 & 48.76 & 3.22523 & 14.6 & & & 64.98 & 0.84 & & & 0.883 & 6.03 & 6.70 & \\
\hline $5 \mathrm{H}-6,14 \mathrm{I}$ & 43.71 & 48.86 & 3.23209 & 14.6 & & & 70.36 & 0.92 & & & 0.898 & 4.50 & 8.10 & \\
\hline $5 \mathrm{H}-7,1$ & 43.81 & 48.96 & 3.23894 & 14.6 & & & 68.75 & 0.92 & & & 0.919 & 5.97 & 6.60 & \\
\hline $5 \mathrm{H}-7,11$ & 43.91 & 49.06 & 3.24579 & 14.6 & & & 67.94 & 0.90 & & & 0.912 & 4.48 & 6.40 & \\
\hline $5 \mathrm{H}-7,21$ & 44.01 & 49.16 & 3.25265 & 14.6 & & & 63.94 & 0.81 & & & 0.869 & 3.81 & 7.50 & \\
\hline $5 \mathrm{H}-7,31$ & 44.11 & 49.26 & 3.25950 & 14.6 & & & 63.28 & 0.84 & & & 0.905 & 4.13 & 8.00 & \\
\hline $5 \mathrm{H}-7,41$ & 44.21 & 49.36 & 3.26636 & 14.6 & & & 63.88 & 0.81 & & & 0.869 & 5.43 & 8.63 & \\
\hline $5 \mathrm{H}-7,51$ & 44.31 & 49.46 & 3.27321 & 14.6 & & & 56.38 & 0.71 & & & 0.862 & 4.47 & 11.50 & \\
\hline \multicolumn{15}{|l|}{$121-758 \mathrm{~B}-$} \\
\hline $5 \mathrm{H}-4,131$ & 43.81 & 49.47 & 3.27389 & 14.7 & & & 55.90 & 0.71 & & & 0.862 & 3.07 & 10.65 & \\
\hline $5 \mathrm{H}-4,141$ & 43.91 & 49.57 & 3.28075 & 14.6 & & & 62.48 & 0.84 & & & 0.919 & 4.08 & 8.30 & \\
\hline $5 \mathrm{H}-5,1$ & 44.01 & 49.67 & 3.28760 & 14.6 & & & 64.95 & 0.89 & & & 0.940 & 3.72 & 6.53 & \\
\hline $5 \mathrm{H}-5,11$ & 44.11 & 49.77 & 3.29446 & 14.6 & & & 64.87 & 0.87 & & & 0.919 & 4.11 & 7.10 & \\
\hline
\end{tabular}




$\begin{array}{lllll}\text { 5H-5, 21 } & 44.21 & 49.87 & 3.30131 & 14.6 \\ \text { 5H-5, 31 } & 44.31 & 49.97 & 3.30816 & 14.6 \\ \text { 5H-5, 41 } & 44.41 & 50.07 & 3.31502 & 14.6 \\ \text { 5H-5, 51 } & 44.51 & 50.17 & 3.32187 & 14.6 \\ \text { 5H-5, 61 } & 44.61 & 50.27 & 3.32872 & 14.6 \\ \text { 5H-5, 71 } & 44.71 & 50.37 & 3.33558 & 14.6 \\ \text { 5H-5, 81 } & 44.81 & 50.47 & 3.34243 & 14.6 \\ \text { 5H-5, 91 } & 44.91 & 50.57 & 3.34928 & 14.6 \\ \text { 5H-5, 101 } & 45.01 & 50.67 & 3.35614 & 14.6 \\ \text { 5H-5, 111 } & 45.11 & 50.77 & 3.36299 & 14.6 \\ \text { 5H-5, 121 } & 45.21 & 50.87 & 3.36984 & 14.6 \\ \text { 5H-5, 131 } & 45.31 & 50.97 & 3.37670 & 14.6 \\ \text { 5H-5, 141 } & 45.41 & 51.07 & 3.38355 & 14.6 \\ \text { 5H-6, 1 } & 45.51 & 51.17 & 3.39041 & 14.6 \\ \text { 5H-6, 21 } & 45.71 & 51.37 & 3.40279 & 16.2 \\ \text { 5H-6, 30 } & 45.80 & 51.46 & 3.40698 & 21.5 \\ \text { 5H-6, 41 } & 45.91 & 51.57 & 3.41209 & 21.5 \\ \text { 5H-6, 51 } & 46.01 & 51.67 & 3.41674 & 21.5 \\ \text { 5H-6, 61 } & 46.11 & 51.77 & 3.42140 & 21.5 \\ \text { 5H-6, 71 } & 46.21 & 51.87 & 3.42605 & 21.5 \\ \text { 5H-6, 81 } & 46.31 & 51.97 & 3.43070 & 21.5 \\ \text { 5H-6, 91 } & 46.41 & 52.07 & 3.43535 & 21.5\end{array}$

$\begin{array}{ll}66.68 & 0.93 \\ 67.88 & 0.92 \\ 67.80 & 0.87 \\ 69.19 & 0.99 \\ 68.94 & 0.95 \\ 69.79 & 0.93 \\ 68.70 & 0.94 \\ 67.36 & 0.91 \\ 67.43 & 0.90 \\ 61.32 & 0.84 \\ 69.18 & 0.92 \\ 69.05 & 0.89 \\ 67.93 & 0.86 \\ 69.99 & 0.97 \\ 73.35 & 1.01 \\ 71.68 & 1.40 \\ 74.09 & 1.52 \\ 68.75 & 1.33 \\ 66.34 & 1.34 \\ 69.05 & 1.38 \\ 68.31 & 1.40 \\ 70.24 & 1.40\end{array}$

$\begin{array}{llr}0.955 & 3.63 & 7.50 \\ 0.926 & 3.54 & 7.67 \\ 0.883 & 5.37 & 7.13 \\ 0.983 & 5.76 & 8.10 \\ 0.940 & 4.08 & 8.07 \\ 0.912 & 4.78 & 7.80 \\ 0.940 & 3.95 & 8.50 \\ 0.926 & 4.04 & 8.53 \\ 0.912 & 3.11 & 8.73 \\ 0.933 & 2.09 & 10.70 \\ 0.912 & 3.39 & 9.00 \\ 0.883 & 3.60 & 11.10 \\ 0.865 & 3.30 & 9.70 \\ 0.955 & 4.16 & 4.83 \\ 0.855 & 8.30 & 6.60 \\ 0.912 & 6.30 & 6.90 \\ 0.955 & 6.75 & 9.63 \\ 0.898 & 3.91 & 21.00 \\ 0.940 & 2.75 & 27.70 \\ 0.926 & 2.89 & 12.73 \\ 0.955 & 2.86 & 11.50 \\ 0.926 & 4.49 & 9.83\end{array}$

121-758A-

$\begin{array}{ll}69.24 & 1.34 \\ 64.19 & 1.20 \\ 63.74 & 1.21 \\ 64.19 & 1.27 \\ 69.40 & 1.30 \\ 74.29 & 1.35 \\ 68.68 & 1.33 \\ 70.50 & 1.30 \\ 66.70 & 1.29 \\ 66.23 & 1.52 \\ 65.80 & 1.25 \\ 68.25 & 1.38 \\ 67.30 & 1.28 \\ 65.22 & 1.17 \\ 64.37 & 1.09 \\ 65.06 & 1.10 \\ 63.97 & 1.08 \\ 66.74 & 1.13 \\ 66.17 & 1.11 \\ 65.48 & 1.18 \\ 69.76 & 1.31 \\ 72.10 & 1.41 \\ 73.23 & 1.30 \\ 70.68 & 1.27 \\ 74.27 & 1.34 \\ 68.85 & 1.31 \\ 67.23 & 1.40 \\ 76.34 & 1.37 \\ 67.91 & 1.28 \\ 71.13 & 1.44 \\ 70.55 & 1.40 \\ 70.98 & 1.39 \\ 72.63 & 1.49 \\ 73.93 & 1.37 \\ 72.83 & 1.38 \\ 75.88 & 1.48 \\ 74.07 & 1.47 \\ 71.96 & 1.39 \\ 72.18 & 1.42\end{array}$

$\begin{array}{rrr}0.890 & 6.55 & 9.75 \\ 0.869 & 4.52 & 12.40 \\ 0.883 & 3.18 & 18.60 \\ 0.919 & 4.00 & 29.87 \\ 0.869 & 6.10 & 36.90 \\ 0.848 & 11.66 & 9.90 \\ 0.898 & 10.41 & 6.17 \\ 0.855 & 9.56 & 7.00 \\ 0.898 & 5.34 & 7.10 \\ 1.068 & 3.11 & 9.10 \\ 0.883 & 3.55 & 8.67 \\ 0.940 & 4.73 & 8.50 \\ 0.883 & 4.73 & 7.20 \\ 0.834 & 3.25 & 9.13 \\ 0.784 & 3.19 & 7.90 \\ 0.784 & 3.45 & 8.03 \\ 0.784 & 3.36 & 6.23 \\ 0.784 & 3.35 & 6.00 \\ 0.784 & 2.72 & 7.87 \\ 0.841 & 3.02 & 9.23 \\ 0.876 & 3.62 & 7.50 \\ 0.912 & 5.47 & 6.23 \\ 0.826 & 6.83 & 6.00 \\ 0.834 & 6.74 & 5.80 \\ 0.841 & 8.53 & 7.53 \\ 0.883 & 4.41 & 12.20 \\ 0.969 & 3.11 & 22.70 \\ 0.834 & 11.00 & 10.80 \\ 0.876 & 5.52 & 11.93 \\ 0.940 & 5.43 & 19.10 \\ 0.926 & 3.83 & 16.37 \\ 0.912 & 4.18 & 19.17 \\ 0.955 & 5.35 & 29.30 \\ 0.862 & 5.53 & 11.60 \\ 0.883 & 6.89 & 9.67 \\ 0.905 & 7.32 & 8.37 \\ 0.926 & 5.06 & 7.07 \\ 0.898 & 5.05 & 6.03 \\ 0.912 & 8.29 & 6.20 \\ . & & \end{array}$




\begin{tabular}{|c|c|c|c|c|c|c|c|c|c|c|c|c|c|c|}
\hline $\begin{array}{l}\text { Core, section, } \\
\text { interval }(\mathrm{cm})\end{array}$ & $\begin{array}{l}\text { ODP } \\
\text { depth } \\
\text { (mbsf) }\end{array}$ & $\begin{array}{l}\text { Composite } \\
\text { depth } \\
\text { (m) }\end{array}$ & $\begin{array}{l}\text { Magnetic } \\
\text { age } \\
(\mathrm{m} . \mathrm{y} .)\end{array}$ & $\begin{array}{l}\text { Magnetic } \\
\text { sedimentation } \\
\text { rate } \\
(\mathrm{m} / \mathrm{m} . \mathrm{y} .)\end{array}$ & $\begin{array}{c}\delta^{18} \mathrm{O} \\
\text { age } \\
\text { (m.y.) }\end{array}$ & $\begin{array}{c}\delta^{18} \mathrm{O} \\
\text { sedimentation } \\
\text { rate } \\
(\mathrm{m} / \mathrm{m} . \mathrm{y} .)\end{array}$ & $\begin{array}{c}\text { Mean } \\
\text { (wt } \% \mathrm{CaCO}_{3} \text { ) }\end{array}$ & $\begin{array}{c}\text { Magnetic } \\
\mathrm{CaCO}_{3} \text { MAR } \\
\left(\mathrm{g} / \mathrm{cm}^{2} / \mathrm{k} . \mathrm{y} .\right)\end{array}$ & $\begin{array}{l}\delta^{13} \mathrm{C} \\
\%_{0} \text { to } \\
\text { (PDB) }\end{array}$ & $\begin{array}{l}\delta^{18} \mathrm{O} \\
\%_{0} \text { to } \\
\text { (PDB) }\end{array}$ & $\begin{array}{c}\text { Dry-bulk } \\
\text { density } \\
\left(\mathrm{g} / \mathrm{cm}^{3}\right)\end{array}$ & $\begin{array}{c}\text { Coarse } \\
\text { fraction } \\
\text { (wt } \%>150 \mu \mathrm{m})\end{array}$ & $\begin{array}{c}\text { Interpolated MS } \\
\text { K (10-6) } \\
\text { (cgs) }\end{array}$ & Comment \\
\hline 121-758A-(Cont.) & & & & & & & & & & & & & & \\
\hline $6 \mathrm{H}-3,121$ & 48.61 & 55.98 & 3.61721 & 21.5 & & & 71.68 & 1.45 & & & 0.940 & 7.26 & 7.87 & \\
\hline $6 \mathrm{H}-3,131$ & 48.71 & 56.08 & 3.62186 & 21.5 & & & 72.45 & 1.42 & & & 0.912 & 5.08 & 10.60 & \\
\hline $6 \mathrm{H}-3,141$ & 48.81 & 56.18 & 3.62651 & 21.5 & & & 74.14 & 1.45 & & & 0.912 & 5.84 & 6.10 & \\
\hline $6 \mathrm{H}-4,1$ & 48.91 & 56.28 & 3.63116 & 21.5 & & & 67.60 & 1.26 & & & 0.869 & 4.14 & 6.77 & \\
\hline $6 \mathrm{H}-4,11$ & 49.01 & 56.38 & 3.63581 & 21.5 & & & 69.34 & 1.39 & & & 0.933 & 4.71 & 6.80 & \\
\hline $6 \mathrm{H}-4,21$ & 49.11 & 56.48 & 3.64047 & 21.5 & & & 68.69 & 1.39 & & & 0.940 & 3.81 & 7.80 & \\
\hline $6 \mathrm{H}-4,31$ & 49.21 & 56.58 & 3.64512 & 21.5 & & & 66.87 & 1.36 & & & 0.947 & 5.25 & 6.93 & \\
\hline $6 \mathrm{H}-4,41$ & 49.31 & 56.68 & 3.64977 & 21.5 & & & 72.30 & 1.44 & & & 0.926 & 6.69 & 5.93 & \\
\hline $6 \mathrm{H}-4,51$ & 49.41 & 56.78 & 3.65442 & 21.5 & & & 73.36 & 1.60 & & & 1.012 & 10.89 & 5.40 & \\
\hline $6 \mathrm{H}-4,61$ & 49.51 & 56.88 & 3.65907 & 21.5 & & & 73.49 & 1.52 & & & 0.962 & 5.69 & 5.57 & \\
\hline $6 \mathrm{H}-4,71$ & 49.61 & 56.98 & 3.66372 & 21.5 & & & 69.43 & 1.40 & & & 0.940 & 7.25 & 5.97 & \\
\hline $6 \mathrm{H}-4,81$ & 49.71 & 57.08 & 3.66837 & 21.5 & & & 69.08 & 1.40 & & & 0.940 & 6.34 & 5.50 & \\
\hline $6 \mathrm{H}-4,91$ & 49.81 & 57.18 & 3.67302 & 21.5 & & & 67.22 & 1.48 & & & 1.026 & 4.58 & 6.20 & \\
\hline $6 \mathrm{H}-4,101$ & 49.91 & 57.28 & 3.67767 & 21.5 & & & 71.79 & 1.32 & & & 0.855 & 7.13 & 5.33 & \\
\hline $6 \mathrm{H}-4,111$ & 50.01 & 57.38 & 3.68233 & 21.5 & & & 75.31 & 1.59 & & & 0.983 & 9.16 & 4.70 & \\
\hline $6 \mathrm{H}-4,121$ & 50.11 & 57.48 & 3.68698 & 21.5 & & & 75.56 & 1.46 & & & 0.898 & 11.35 & 4.70 & \\
\hline $6 \mathrm{H}-4,131$ & 50.21 & 57.58 & 3.69163 & 21.5 & & & 73.78 & 1.40 & & & 0.883 & 11.62 & 5.10 & \\
\hline $6 \mathrm{H}-4,141$ & 50.31 & 57.68 & 3.69628 & 21.5 & & & 72.23 & 1.42 & & & 0.912 & 8.39 & 6.00 & \\
\hline $6 \mathrm{H}-5,1$ & 50.41 & 57.78 & 3.70093 & 21.5 & & & 70.10 & 1.51 & & & 1.004 & 7.39 & 6.43 & \\
\hline $6 \mathrm{H}-5,11$ & 50.51 & 57.88 & 3.70558 & 21.5 & & & 67.66 & 1.43 & & & 0.983 & 5.87 & 6.37 & \\
\hline $6 \mathrm{H}-5,21$ & 50.61 & 57.98 & 3.71023 & 21.5 & & & 70.70 & 1.28 & & & 0.841 & 7.32 & 5.40 & \\
\hline $6 \mathrm{H}-5,31$ & 50.71 & 58.08 & 3.71488 & 21.5 & & & 66.58 & 1.27 & & & 0.890 & 6.96 & 4.80 & \\
\hline $6 \mathrm{H}-5,41$ & 50.81 & 58.18 & 3.71954 & 21.5 & & & 67.10 & 1.23 & & & 0.855 & 5.73 & 6.50 & \\
\hline $6 \mathrm{H}-5,51$ & 50.91 & 58.28 & 3.72419 & 21.5 & & & 44.09 & 0.92 & & & 0.969 & 5.30 & 3.80 & Ash blebs \\
\hline $6 \mathrm{H}-5,61$ & 51.01 & 58.38 & 3.72884 & 21.5 & & & 67.55 & 1.31 & & & 0.905 & 8.31 & 4.67 & \\
\hline $6 \mathrm{H}-5,71$ & 51.11 & 58.48 & 3.73349 & 21.5 & & & 72.83 & 1.45 & & & 0.926 & 6.93 & 4.10 & \\
\hline $6 \mathrm{H}-5,81$ & 51.21 & 58.58 & 3.73814 & 21.5 & & & 70.21 & 1.39 & & & 0.919 & 6.64 & 4.90 & \\
\hline $6 \mathrm{H}-5,91$ & 51.31 & 58.68 & 3.74279 & 21.5 & & & 70.65 & 1.32 & & & 0.869 & 8.40 & 3.50 & \\
\hline $6 \mathrm{H}-5,101$ & 51.41 & 58.78 & 3.74744 & 21.5 & & & 71.80 & 1.39 & & & 0.898 & 6.34 & 3.57 & \\
\hline $6 \mathrm{H}-5,111$ & 51.51 & 58.88 & 3.75209 & 21.5 & & & 70.51 & 1.41 & & & 0.933 & 5.63 & 3.80 & \\
\hline $6 \mathrm{H}-5,121$ & 51.61 & 58.98 & 3.75674 & 21.5 & & & 69.46 & 1.40 & & & 0.940 & 4.86 & 4.10 & \\
\hline $6 \mathrm{H}-6,1$ & 51.91 & 59.28 & 3.77070 & 21.5 & & & 68.13 & 1.36 & & & 0.929 & 7.24 & 5.78 & \\
\hline $6 \mathrm{H}-6,11$ & 52.01 & 59.38 & 3.77535 & 21.5 & & & 60.26 & 1.26 & & & 0.969 & 4.97 & 8.00 & \\
\hline $6 \mathrm{H}-6,21$ & 52.11 & 59.48 & 3.78000 & 21.5 & & & 61.28 & 1.22 & & & 0.926 & 3.25 & 10.00 & \\
\hline $6 \mathrm{H}-6,31$ & 52.21 & 59.58 & 3.78465 & 21.5 & & & 56.66 & 1.11 & & & 0.912 & 4.42 & 12.33 & \\
\hline $6 \mathrm{H}-6,41$ & 52.31 & 59.68 & 3.78930 & 21.5 & & & 57.25 & 1.14 & & & 0.926 & 3.85 & 10.97 & \\
\hline $6 \mathrm{H}-6,51$ & 52.41 & 59.78 & 3.79395 & 21.5 & & & 72.23 & 1.46 & & & 0.940 & 6.89 & 5.70 & \\
\hline $6 \mathrm{H}-6,61$ & 52.51 & 59.88 & 3.79860 & 21.5 & & & 71.35 & 1.41 & & & 0.919 & 7.76 & 6.70 & \\
\hline $6 \mathrm{H}-6,71$ & 52.61 & 59.98 & 3.80326 & 21.5 & & & 68.13 & 1.40 & & & 0.955 & 4.95 & 6.40 & \\
\hline $6 \mathrm{H}-6,81$ & 52.71 & 60.08 & 3.80791 & 21.5 & & & 68.62 & 1.30 & & & 0.883 & 5.10 & 6.30 & \\
\hline $6 \mathrm{H}-6,91$ & 52.81 & 60.18 & 3.81256 & 21.5 & & & 68.90 & 1.35 & & & 0.912 & 4.74 & 8.03 & \\
\hline $6 \mathrm{H}-6,101$ & 52.91 & 60.28 & 3.81721 & 21.5 & & & 67.26 & 1.19 & & & 0.826 & 5.01 & 11.90 & \\
\hline $6 \mathrm{H}-6,111$ & 53.01 & 60.38 & 3.82186 & 21.5 & & & 58.28 & 1.12 & & & 0.890 & 3.48 & 27.90 & \\
\hline $6 \mathrm{H}-6,121$ & 53.11 & 60.48 & 3.82651 & 21.5 & & & 63.56 & 1.36 & & & 0.997 & 4.60 & 17.33 & \\
\hline $6 \mathrm{H}-6,131$ & 53.21 & 60.58 & 3.83116 & 21.5 & & & 65.87 & 1.31 & & & 0.926 & 5.21 & 7.00 & \\
\hline $6 \mathrm{H}-6,141$ & 53.31 & 60.68 & 3.83581 & 21.5 & & & 55.85 & 1.16 & & & 0.969 & 4.93 & 10.50 & \\
\hline $6 \mathrm{H}-7,1$ & 53.41 & 60.78 & 3.84047 & 21.5 & & & 69.54 & 1.45 & & & 0.969 & 5.71 & 5.67 & \\
\hline $6 \mathrm{H}-7,11$ & 53.51 & 60.88 & 3.84512 & 21.5 & & & 72.81 & 1.29 & & & 0.826 & 6.61 & 5.40 & \\
\hline $6 \mathrm{H}-7,21$ & 53.61 & 60.98 & 3.84977 & 21.5 & & & 71.48 & 1.39 & & & 0.905 & 6.55 & 7.00 & \\
\hline $6 \mathrm{H}-7,31$ & 53.71 & 61.08 & 3.85442 & 21.5 & & & 73.40 & 1.44 & & & 0.912 & 7.07 & 7.37 & \\
\hline $6 \mathrm{H}-7,41$ & 53.81 & 61.18 & 3.85907 & 21.5 & & & 71.60 & 1.46 & & & 0.947 & 6.31 & 6.30 & \\
\hline $6 \mathrm{H}-7,51$ & 53.91 & 61.28 & 3.86372 & 21.5 & & & 70.96 & 1.41 & & & 0.926 & 5.71 & 6.00 & \\
\hline $6 \mathrm{H}-7,61$ & 54.01 & 61.38 & 3.86837 & 21.5 & & & 71.57 & 1.39 & & & 0.905 & 5.73 & 6.03 & \\
\hline $6 \mathrm{H}-7,71$ & 54.11 & 61.48 & 3.87302 & 21.5 & & & 25.13 & 0.51 & & & 0.940 & 2.37 & 6.40 & \\
\hline
\end{tabular}


121-758B-

$\begin{array}{lllll}6 \mathrm{H}-4,61 & 52.81 & 61.49 & 3.87349 & 21.3 \\ 6 \mathrm{H}-4,71 & 52.91 & 61.59 & 3.87814 & 21.5 \\ 6 \mathrm{H}-4,81 & 53.01 & 61.69 & 3.88335 & 19.2 \\ 6 \mathrm{H}-4,91 & 53.11 & 61.79 & 3.88894 & 17.9 \\ 6 \mathrm{H}-4,101 & 53.21 & 61.89 & 3.89453 & 17.9 \\ 6 \mathrm{H}-4,111 & 53.31 & 61.99 & 3.90012 & 17.9 \\ 6 \mathrm{H}-4,121 & 53.41 & 62.09 & 3.90571 & 17.9 \\ 6 \mathrm{H}-4,131 & 53.51 & 62.19 & 3.91130 & 17.9 \\ 6 \mathrm{H}-4,141 & 53.61 & 62.29 & 3.91689 & 17.9 \\ 6 \mathrm{H}-5,1 & 53.71 & 62.39 & 3.9248 & 17.9 \\ 6 \mathrm{H}-5,11 & 53.81 & 62.49 & 3.92807 & 17.9 \\ 6 \mathrm{H}-5,21 & 53.91 & 62.59 & 3.93366 & 17.9 \\ 6 \mathrm{H}-5,31 & 54.01 & 62.69 & 3.93925 & 17.9 \\ 6 \mathrm{H}-5,41 & 54.11 & 62.79 & 3.94484 & 17.9 \\ 6 \mathrm{H}-5,51 & 54.21 & 62.89 & 3.95043 & 17.9 \\ 6 \mathrm{H}-5,61 & 54.31 & 62.99 & 3.95602 & 17.9 \\ 6 \mathrm{H}-5,71 & 54.41 & 63.09 & 3.96162 & 17.9 \\ 6 \mathrm{H}-5,81 & 54.51 & 63.19 & 3.96721 & 17.9\end{array}$

$\begin{array}{ll}66.31 & 1.33 \\ 68.83 & 1.39 \\ 72.27 & 1.28 \\ 71.66 & 1.11 \\ 73.83 & 1.19 \\ 76.58 & 1.27 \\ 75.71 & 1.29 \\ 71.46 & 1.15 \\ 71.40 & 1.10 \\ 71.52 & 1.18 \\ 71.29 & 1.14 \\ 68.38 & 1.10 \\ 67.59 & 1.11 \\ 69.46 & 1.12 \\ 71.26 & 1.14 \\ 72.05 & 1.19 \\ 69.91 & 1.14 \\ 69.13 & 1.16\end{array}$

0.940

$\begin{array}{ll}7.72 & 6.80 \\ 8.29 & 6.17 \\ 9.10 & 4.60 \\ 7.10 & 4.87 \\ 6.42 & 4.60 \\ 6.71 & 3.80 \\ 3.47 & 5.70 \\ 3.80 & 6.40 \\ 4.83 & 6.40 \\ 5.40 & 6.33 \\ 6.16 & 7.03 \\ 2.76 & 8.60 \\ 2.57 & 8.63 \\ 4.38 & 7.00 \\ 6.25 & 6.60 \\ 5.52 & 8.03 \\ 5.69 & 7.50 \\ 3.83 & 9.70\end{array}$

121-758A-

$\begin{array}{lllll}7 \mathrm{H}-1,1 & 54.01 & 63.20 & 3.96776 & 18.2 \\ 7 \mathrm{H}-1,11 & 54.11 & 63.30 & 3.97363 & 17.0 \\ 7 \mathrm{H}-1,21 & 54.21 & 63.40 & 3.97967 & 16.6 \\ 7 \mathrm{H}-1,31 & 54.31 & 63.50 & 3.98572 & 16.5 \\ 7 \mathrm{H}-1,41 & 54.41 & 63.60 & 3.99177 & 16.5 \\ 7 \mathrm{H}-1,51 & 54.51 & 63.70 & 3.99781 & 16.6 \\ 7 \mathrm{H}-1,61 & 54.61 & 63.80 & 4.00386 & 16.5 \\ 7 \mathrm{H}-1,71 & 54.71 & 63.90 & 4.0091 & 16.5 \\ 7 \mathrm{H}-1,81 & 54.81 & 64.00 & 4.01595 & 16.5 \\ 7 \mathrm{H}-1,91 & 54.91 & 64.10 & 4.02200 & 16.5 \\ 7 \mathrm{H}-1,101 & 55.01 & 64.20 & 4.02805 & 16.5 \\ 7 \mathrm{H}-1,111 & 55.11 & 64.30 & 4.03409 & 16.6 \\ 7 \mathrm{H}-1,121 & 55.21 & 64.40 & 4.04014 & 16.5 \\ 7 \mathrm{H}-1,131 & 55.31 & 64.50 & 4.04619 & 16.5 \\ 7 \mathrm{H}-1,141 & 55.41 & 64.60 & 4.05223 & 16.6 \\ 7 \mathrm{H}-2,1 & 55.51 & 64.70 & 4.05828 & 16.5 \\ 7 \mathrm{H}-2,11 & 55.61 & 64.80 & 4.06433 & 16.5 \\ 7 \mathrm{H}-2,21 & 55.71 & 64.90 & 4.07037 & 16.6 \\ 7 \mathrm{H}-2,31 & 55.81 & 65.00 & 4.07642 & 16.5 \\ 7 \mathrm{H}-2,41 & 55.91 & 65.10 & 4.08247 & 16.5 \\ 7 \mathrm{H}-2,51 & 56.01 & 65.20 & 4.08851 & 16.6 \\ 7 \mathrm{H}-2,61 & 56.11 & 65.30 & 4.09456 & 16.5 \\ 7 \mathrm{H}-2,71 & 56.21 & 65.40 & 4.10057 & 16.6 \\ 7 \mathrm{H}-2,81 & 56.31 & 65.50 & 4.10629 & 17.5 \\ 7 \mathrm{H}-2,91 & 56.41 & 65.60 & 4.11200 & 17.5 \\ 7 \mathrm{H}-2,101 & 56.51 & 65.70 & 4.11771 & 17.5 \\ 7 \mathrm{H}-2,111 & 56.61 & 65.80 & 4.12343 & 17.5 \\ 7 \mathrm{H}-2,121 & 56.71 & 65.90 & 4.12914 & 17.5 \\ 7 \mathrm{H}-2,131 & 56.81 & 66.00 & 4.13486 & 17.5 \\ 7 \mathrm{H}-2,141 & 56.91 & 66.10 & 4.14057 & 17.5 \\ 7 \mathrm{H}-3,1 & 57.01 & 66.20 & 4.14629 & 17.5 \\ 7 \mathrm{H}-3,11 & 57.11 & 66.30 & 4.15200 & 17.5 \\ 7 \mathrm{H}-3,21 & 57.21 & 66.40 & 4.15771 & 17.5 \\ 7 \mathrm{H}-3,31 & 57.31 & 66.50 & 4.16343 & 17.5 \\ 7 \mathrm{H}-3,41 & 57.41 & 66.60 & 4.16914 & 17.5 \\ 7 \mathrm{H}-3,51 & 57.51 & 66.70 & 4.17486 & 17.5 \\ 7 \mathrm{H}-3,61 & 57.61 & 66.80 & 4.18057 & 17.5 \\ 7 \mathrm{H}-3,71 & 57.71 & 66.90 & 4.18629 & 17.5 \\ 7 \mathrm{H}-3,81 & 57.81 & 67.00 & 4.19200 & 17.5 \\ 7 \mathrm{H}-3,91 & 57.91 & 67.10 & 4.19771 & 17.5 \\ 7 \mathrm{H}-3,101 & 58.01 & 67.20 & 4.20343 & 17.5\end{array}$

$\begin{array}{rl}69.11 & 1.04 \\ 52.69 & 0.74 \\ 58.65 & 0.83 \\ 65.40 & 0.89 \\ 69.83 & 1.08 \\ 66.37 & 0.99 \\ 57.42 & 0.84 \\ 60.64 & 0.93 \\ 69.60 & 1.01 \\ 71.70 & 1.10 \\ 72.09 & 1.10 \\ 64.79 & 1.12 \\ 61.63 & 1.13 \\ 62.06 & 0.96 \\ 71.98 & 1.09 \\ 74.16 & 1.15 \\ 74.24 & 1.08 \\ 72.15 & 1.04 \\ 69.64 & 1.07 \\ 69.89 & 1.04 \\ 72.35 & 1.06 \\ 72.98 & 1.13 \\ 73.27 & 1.16 \\ 72.86 & 1.18 \\ 71.05 & 1.13 \\ 68.20 & 1.05 \\ 69.60 & 1.13 \\ 6.22 & 0.11 \\ 73.65 & 1.11 \\ 75.92 & 1.23 \\ 75.79 & 1.18 \\ 75.74 & 1.12 \\ 74.35 & 1.21 \\ 69.39 & 1.04 \\ 47.57 & 0.68 \\ 75.65 & 1.21 \\ 72.38 & 1.17 \\ 61.82 & 0.95 \\ 73.25 & 1.10 \\ 76.11 & 1.22 \\ 76.53 & 1.18\end{array}$

$\begin{array}{llr}0.829 & 5.38 & 9.47 \\ 0.829 & 3.14 & 26.97 \\ 0.855 & 2.44 & 15.10 \\ 0.826 & 3.23 & 18.83 \\ 0.940 & 4.67 & 8.80 \\ 0.898 & 3.21 & 9.40 \\ 0.883 & 2.36 & 15.80 \\ 0.926 & 2.84 & 15.87 \\ 0.876 & 3.22 & 7.90 \\ 0.926 & 4.14 & 6.53 \\ 0.926 & 5.14 & 4.47 \\ 1.040 & 2.56 & 8.30 \\ 1.111 & 2.57 & 11.23 \\ 0.940 & 2.08 & 9.97 \\ 0.912 & 2.99 & 6.00 \\ 0.937 & 5.50 & 6.20 \\ 0.883 & 4.88 & 7.87 \\ 0.869 & 3.77 & 7.50 \\ 0.933 & 2.30 & 8.33 \\ 0.898 & 2.97 & 8.10 \\ 0.883 & 4.52 & 6.90 \\ 0.933 & 5.14 & 6.33 \\ 0.955 & 4.01 & 6.33 \\ 0.926 & 5.04 & 6.50 \\ 0.912 & 3.65 & 7.27 \\ 0.883 & 5.20 & 7.87 \\ 0.926 & 4.56 & 11.10 \\ 1.040 & & 35.02 \\ 0.862 & 3.51 & 7.57 \\ 0.926 & 4.93 & 7.10 \\ 0.890 & 4.24 & 5.73 \\ 0.841 & 5.67 & 6.27 \\ 0.926 & 6.07 & 7.30 \\ 0.855 & 6.46 & 10.57 \\ 0.812 & 6.66 & 20.03 \\ 0.912 & 9.18 & 5.50 \\ 0.926 & 4.14 & 8.23 \\ 0.883 & 2.26 & 13.20 \\ 0.855 & 4.17 & 7.50 \\ 0.912 & 6.36 & 5.27 \\ 0.883 & 7.31 & 5.27\end{array}$




\begin{tabular}{|c|c|c|c|c|c|c|c|c|c|c|c|c|c|c|c|}
\hline $\begin{array}{l}\text { Core, section, } \\
\text { interval }(\mathrm{cm})\end{array}$ & $\begin{array}{l}\text { ODP } \\
\text { depth } \\
\text { (mbsf) }\end{array}$ & $\begin{array}{l}\text { Composite } \\
\text { depth } \\
\text { (m) }\end{array}$ & $\begin{array}{c}\text { Magnetic } \\
\text { age } \\
\text { (m.y.) }\end{array}$ & $\begin{array}{c}\text { Magnetic } \\
\text { sedimentation } \\
\text { rate } \\
(\mathrm{m} / \mathrm{m} . \mathrm{y} .)\end{array}$ & $\begin{array}{l}\delta^{18} \mathrm{O} \\
\text { age } \\
\text { (m.y.) }\end{array}$ & $\begin{array}{c}\delta^{18} \mathrm{O} \\
\text { sedimentation } \\
\text { rate } \\
(\mathrm{m} / \mathrm{m} . \mathrm{y} .)\end{array}$ & $\begin{array}{c}\text { Mean } \\
\left(w t \% \mathrm{CaCO}_{3}\right)\end{array}$ & $\begin{array}{c}\text { Magnetic } \\
\mathrm{CaCO}_{3} \text { MAR } \\
\left(\mathrm{g} / \mathrm{cm}^{2} / \mathrm{k} . \mathrm{y} .\right)\end{array}$ & $\begin{array}{l}\delta^{13} \mathrm{C} \\
\%_{0} \text { to } \\
\text { (PDB) }\end{array}$ & $\begin{array}{l}\delta^{18} \mathrm{O} \\
\%_{0} \text { to } \\
\text { (PDB) }\end{array}$ & $\begin{array}{l}\text { Dry-bulk } \\
\text { density } \\
\left(\mathrm{g} / \mathrm{cm}^{3}\right)\end{array}$ & $\begin{array}{c}\text { Coarse } \\
\text { fraction } \\
\text { (wt \% }>150 \mu \mathrm{m})\end{array}$ & $\begin{array}{c}\text { Interpolated MS } \\
\text { K (10-6) } \\
\text { (cgs) }\end{array}$ & & Comment \\
\hline \multicolumn{16}{|l|}{ 121-758A-(Cont.) } \\
\hline $7 \mathrm{H}-3,111$ & 58.11 & 67.30 & 4.20914 & 17.5 & & & 72.00 & 1.12 & & & 0.890 & 7.56 & 5.70 & & \\
\hline $7 \mathrm{H}-3,121$ & 58.21 & 67.40 & 4.21486 & 17.5 & & & 71.76 & 1.09 & & & 0.869 & 6.85 & 5.97 & & \\
\hline $7 \mathrm{H}-3,13 \mathrm{I}$ & 58.31 & 67.50 & 4.22057 & 17.5 & & & 73.85 & 1.25 & & & 0.969 & 3.48 & 6.30 & & \\
\hline $7 \mathrm{H}-3,141$ & 58.41 & 67.60 & 4.22629 & 17.5 & & & 69.36 & 1.17 & & & 0.962 & 4.29 & 7.70 & & \\
\hline $7 \mathrm{H}-4,1$ & 58.51 & 67.70 & 4.23200 & 17.5 & & & 72.98 & 1.14 & & & 0.890 & 4.59 & 6.63 & & \\
\hline $7 \mathrm{H}-4,11$ & 58.61 & 67.80 & 4.23771 & 17.5 & & & 78.75 & 1.19 & & & 0.862 & 6.37 & 5.77 & & \\
\hline $7 \mathrm{H}-4,21$ & 58.71 & 67.90 & 4.24337 & 17.7 & & & 74.27 & 1.18 & & & 0.898 & 7.48 & 6.00 & & \\
\hline $7 \mathrm{H}-4,31$ & 58.81 & 68.00 & 4.24898 & 17.8 & & & 64.11 & 1.10 & & & 0.962 & 5.43 & 9.47 & & \\
\hline $7 \mathrm{H}-4,41$ & 58.91 & 68.10 & 4.25460 & 17.8 & & & 50.11 & 0.89 & & & 0.997 & 4.97 & 9.40 & Ash & \\
\hline $7 \mathrm{H}-4,51$ & 59.01 & 68.20 & 4.26021 & 17.8 & & & 79.30 & 1.33 & & & 0.940 & 4.67 & 5.30 & & \\
\hline $7 \mathrm{H}-4,61$ & 59.11 & 68.30 & 4.26582 & 17.8 & & & 79.65 & 1.40 & & & 0.983 & 3.14 & 5.03 & & \\
\hline $7 \mathrm{H}-4,71$ & 59.21 & 68.40 & 4.27144 & 17.8 & & & 77.34 & 1.27 & & & 0.926 & 1.40 & 5.93 & & \\
\hline $7 \mathrm{H}-4,81$ & 59.31 & 68.50 & 4.27705 & 17.8 & & & 73.26 & 1.20 & & & 0.919 & 2.08 & 6.20 & & \\
\hline $7 \mathrm{H}-4,91$ & 59.41 & 68.60 & 4.28267 & 17.8 & & & 76.42 & 1.26 & & & 0.926 & 3.61 & 5.83 & & \\
\hline $7 \mathrm{H}-4,101$ & 59.51 & 68.70 & 4.28828 & 17.8 & & & 79.74 & 1.28 & & & 0.898 & 5.16 & 4.50 & & \\
\hline $7 \mathrm{H}-4,111$ & 59.61 & 68.80 & 4.29389 & 17.8 & & & 76.51 & 1.24 & & & 0.912 & 4.05 & 4.00 & & \\
\hline $7 \mathrm{H}-4,121$ & 59.71 & 68.90 & 4.29951 & 17.8 & & & 73.02 & 1.22 & & & 0.940 & 2.81 & 6.43 & & \\
\hline $7 \mathrm{H}-4,131$ & 59.81 & 69.00 & 4.30512 & 17.8 & & & 71.29 & 1.13 & & & 0.890 & 2.34 & 7.63 & & \\
\hline $7 \mathrm{H}-4,141$ & 59.91 & 69.10 & 4.31074 & 17.8 & & & 73.66 & 1.20 & & & 0.912 & 2.61 & 7.00 & & \\
\hline $7 \mathrm{H}-5,1$ & 60.01 & 69.20 & 4.31635 & 17.8 & & & 73.42 & 1.29 & & & 0.983 & 2.69 & 6.73 & & \\
\hline $7 \mathrm{H}-5,11$ & 60.11 & 69.30 & 4.32197 & 17.8 & & & 74.83 & 1.26 & & & 0.947 & 4.12 & 6.33 & & \\
\hline $7 \mathrm{H}-5,2 \mathrm{I}$ & 60.21 & 69.40 & 4.32758 & 17.8 & & & 77.45 & 1.34 & & & 0.969 & 3.73 & 5.30 & & \\
\hline $7 \mathrm{H}-5,31$ & 60.31 & 69.50 & 4.33319 & 17.8 & & & 75.27 & 1.25 & & & 0.933 & 2.71 & 7.07 & & \\
\hline $7 \mathrm{H}-5,41$ & 60.41 & 69.60 & 4.33881 & 17.8 & & & 71.48 & 1.14 & & & 0.898 & 1.35 & 10.27 & & \\
\hline $7 \mathrm{H}-5,51$ & 60.51 & 69.70 & 4.34442 & 17.8 & & & 71.20 & 1.27 & & & 0.997 & 1.96 & 12.60 & & \\
\hline $7 \mathrm{H}-5,61$ & 60.61 & 69.80 & 4.35004 & 17.8 & & & 69.91 & 1.24 & & & 0.997 & 2.55 & 9.63 & & \\
\hline $7 \mathrm{H}-5,71$ & 60.71 & 69.90 & 4.35565 & 17.8 & & & 71.27 & 1.21 & & & 0.955 & 3.77 & 10.13 & & \\
\hline $7 \mathrm{H}-5,81$ & 60.81 & 70.00 & 4.36126 & 17.8 & & & 76.81 & 1.23 & & & 0.898 & 4.67 & 9.00 & & \\
\hline $7 \mathrm{H}-5,91$ & 60.91 & 70.10 & 4.36688 & 17.8 & & & 75.97 & 1.29 & & & 0.955 & 4.33 & 5.10 & & \\
\hline $7 \mathrm{H}-5,101$ & 61.01 & 70.20 & 4.37249 & 17.8 & & & 77.33 & 1.28 & & & 0.926 & 4.28 & 4.03 & & \\
\hline $7 \mathrm{H}-5,111$ & 61.11 & 70.30 & 4.37811 & 17.8 & & & 73.79 & 1.26 & & & 0.962 & 1.59 & 5.70 & & \\
\hline $7 \mathrm{H}-5,12 \mathrm{I}$ & 61.21 & 70.40 & 4.38372 & 17.8 & & & 76.57 & 1.34 & & & 0.983 & 1.97 & 5.97 & & \\
\hline $7 \mathrm{H}-5,131$ & 61.31 & 70.50 & 4.38933 & 17.8 & & & 76.67 & 1.25 & & & 0.912 & 3.39 & 4.53 & & \\
\hline $7 \mathrm{H}-5,141$ & 61.41 & 70.60 & 4.39495 & 17.8 & & & 77.77 & 1.24 & & & 0.898 & 4.04 & 4.60 & & \\
\hline $7 \mathrm{H}-6,1$ & 61.51 & 70.70 & 4.40045 & 18.2 & & & 77.31 & 1.18 & & & 0.841 & 3.20 & 6.27 & & \\
\hline $7 \mathrm{H}-6,11$ & 61.61 & 70.80 & 4.40497 & 22.1 & & & 78.03 & 1.65 & & & 0.955 & 2.96 & 6.57 & & \\
\hline $7 \mathrm{H}-6,21$ & 61.71 & 70.90 & 4.40948 & 22.2 & & & 74.71 & 1.58 & & & 0.955 & 2.43 & 6.80 & & \\
\hline $7 \mathrm{H}-6,31$ & 61.81 & 71.00 & 4.41400 & 22.1 & & & 79.61 & 1.69 & & & 0.962 & 3.73 & 6.20 & & \\
\hline $7 \mathrm{H}-6,41$ & 61.91 & 71.10 & 4.41852 & 22.1 & & & 80.90 & 1.63 & & & 0.912 & 3.92 & 5.33 & & \\
\hline $7 \mathrm{H}-6,51$ & 62.01 & 71.20 & 4.42303 & 22.2 & & & 80.33 & 1.75 & & & 0.983 & 4.23 & 4.70 & & \\
\hline $7 \mathrm{H}-6,61$ & 62.11 & 71.30 & 4.42755 & 22.1 & & & 77.98 & 1.65 & & & 0.955 & 3.53 & 6.10 & & \\
\hline $7 \mathrm{H}-6,71$ & 62.21 & 71.40 & 4.43206 & 22.2 & & & 76.94 & 1.58 & & & 0.926 & 2.17 & 7.77 & & \\
\hline $7 \mathrm{H}-6,81$ & 62.31 & 71.50 & 4.43658 & 22.1 & & & 74.70 & 1.60 & & & 0.969 & 1.94 & 9.10 & & \\
\hline $7 \mathrm{H}-6,91$ & 62.41 & 71.60 & 4.44110 & 22.1 & & & 75.90 & 1.72 & & & 1.026 & 2.31 & 7.33 & & \\
\hline $7 \mathrm{H}-6,101$ & 62.51 & 71.70 & 4.44561 & 22.2 & & & 78.81 & 1.77 & & & 1.012 & 2.73 & 5.03 & & \\
\hline $7 \mathrm{H}-6,111$ & 62.61 & 71.80 & 4.45013 & 22.1 & & & 79.75 & 1.63 & & & 0.926 & 3.44 & 4.60 & & \\
\hline $7 \mathrm{H}-6,121$ & 62.71 & 71.90 & 4.45465 & 22.1 & & & 76.16 & 1.71 & & & 1.012 & 2.88 & 4.73 & & \\
\hline $7 \mathrm{H}-6,131$ & 62.81 & 72.00 & 4.45916 & 22.2 & & & 77.65 & 1.69 & & & 0.983 & 2.80 & 4.30 & & \\
\hline $7 \mathrm{H}-6,141$ & 62.91 & 72.10 & 4.46368 & 22.1 & & & 74.94 & 1.56 & & & 0.940 & 2.68 & 4.80 & & \\
\hline $7 \mathrm{H}-7,1$ & 63.01 & 72.20 & 4.46819 & 22.2 & & & 73.28 & 1.61 & & & 0.990 & 2.62 & 5.60 & & \\
\hline $7 \mathrm{H}-7,11$ & 63.11 & 72.30 & 4.47790 & 10.3 & & & 70.83 & 0.73 & & & 0.997 & 1.80 & 6.43 & & \\
\hline $7 \mathrm{H}-7,21$ & 63.21 & 72.40 & 4.49105 & 7.6 & & & 77.00 & 0.59 & & & 1.012 & 2.60 & 5.50 & & \\
\hline $7 \mathrm{H}-7,31$ & 63.31 & 72.50 & 4.50421 & 7.6 & & & 80.49 & 0.60 & & & 0.983 & 3.47 & 4.60 & & \\
\hline $7 \mathrm{H}-7,41$ & 63.41 & 72.60 & 4.51737 & 7.6 & & & 75.99 & 0.55 & & & 0.955 & 2.20 & 5.30 & & \\
\hline
\end{tabular}




$\begin{array}{ccccr}7 \mathrm{H}-7,51 & 63.51 & 72.70 & 4.53053 & 7.6 \\ 7 \mathrm{H}-7,61 & 63.61 & 72.80 & 4.54368 & 7.6 \\ \text { 121-758B- } & & & & \\ 7 \mathrm{H}-4,121 & 63.01 & 72.81 & 4.54500 & 7.6 \\ 7 \mathrm{H}-4,131 & 63.11 & 72.91 & 4.55816 & 7.6 \\ 7 \mathrm{H}-4,141 & 63.21 & 73.01 & 4.57049 & 8.1 \\ 7 \mathrm{H}-5,1 & 63.31 & 73.11 & 4.57535 & 20.6 \\ 7 \mathrm{H}-5,11 & 63.41 & 73.21 & 4.58022 & 20.5 \\ 7 \mathrm{H}-5,21 & 63.51 & 73.31 & 4.58508 & 20.6 \\ 7 \mathrm{H}-5,31 & 63.61 & 73.41 & 4.58995 & 20.5 \\ 7 \mathrm{H}-5,41 & 63.71 & 73.51 & 4.59482 & 20.5 \\ 7 \mathrm{H}-5,51 & 63.81 & 73.61 & 4.59968 & 20.6 \\ 7 \mathrm{H}-5,61 & 63.91 & 73.71 & 4.60455 & 20.5 \\ 7 \mathrm{H}-5,71 & 64.01 & 73.81 & 4.60942 & 20.5 \\ 7 \mathrm{H}-5,81 & 64.11 & 73.91 & 4.61428 & 20.6 \\ 7 \mathrm{H}-5,91 & 64.21 & 74.01 & 4.61915 & 20.5\end{array}$

$\begin{array}{ll}73.97 & 0.53 \\ 74.46 & 0.55 \\ & \\ & \\ 71.91 & 0.53 \\ 42.71 & 0.34 \\ 77.08 & 0.58 \\ 75.12 & 1.56 \\ 78.35 & 1.55 \\ 75.11 & 1.50 \\ 75.37 & 1.49 \\ 78.58 & 1.54 \\ 80.91 & 1.61 \\ 79.64 & 1.58 \\ 78.25 & 1.44 \\ 77.91 & 1.53 \\ 74.12 & 1.52\end{array}$

$\begin{array}{llr}0.940 & 1.75 & 5.30 \\ 0.969 & 2.78 & 6.65 \\ & & \\ & & \\ 0.969 & 2.80 & 7.10 \\ 1.047 & 0.92 & 13.43 \\ 0.926 & 1.70 & 5.10 \\ 1.012 & 2.37 & 4.00 \\ 0.962 & 3.79 & 4.83 \\ 0.969 & 1.67 & 5.80 \\ 0.962 & 1.18 & 5.07 \\ 0.955 & 2.54 & 5.17 \\ 0.969 & 3.78 & 4.30 \\ 0.969 & 4.54 & 3.43 \\ 0.898 & 4.42 & 5.07 \\ 0.955 & 4.17 & 5.10 \\ 0.997 & 2.49 & 5.65\end{array}$

121-758A-

$\begin{array}{lllll}8 \mathrm{H}-1,1 & 63.71 & 74.02 & 4.61963 & 20.8\end{array}$

$\begin{array}{lllll}8 \mathrm{H}-1,11 & 63.81 & 74.12 & 4.62450 & 20.5\end{array}$

$\begin{array}{lllll}8 \mathrm{H}-1,21 & 63.91 & 74.22 & 4.62937 & 20.5 \\ 8 \mathrm{H}-1.31 & 64.01 & 74.32 & 4.63423 & 20.6\end{array}$

$\begin{array}{lllll}8 \mathrm{H}-1,31 & 64.01 & 74.32 & 4.63423 & 20.6 \\ 8 \mathrm{H}-1,41 & 64.11 & 74.42 & 4.63910 & 20.5\end{array}$

$\begin{array}{lllll}8 \mathrm{H}-1,51 & 64.11 & 74.42 & 4.63910 & 20.5 \\ 84.21 & 74.52 & 4.64397 & 20.5\end{array}$

$\begin{array}{lllll}8 \mathrm{H}-1,61 & 64.31 & 74.62 & 4.64883 & 20.6\end{array}$

$\begin{array}{lllll}8 \mathrm{H}-1,71 & 64.41 & 74.72 & 4.65370 & 20.5 \\ & & \end{array}$

$\begin{array}{lllll}8 \mathrm{H}-1,81 & 64.51 & 74.82 & 4.65856 & 20.6 \\ \mathrm{H}-1,91 & 64.61 & 74.92 & 4.66343 & 20.5\end{array}$

$\begin{array}{lllll}8 \mathrm{H}-1,101 & 64.71 & 75.02 & 4.66830 & 20.5\end{array}$

$\begin{array}{lllll}8 \mathrm{H}-1,111 & 64.81 & 75.12 & 4.67316 & 20.6\end{array}$

$\begin{array}{lllll} & \\ \mathrm{H}-1,121 & 64.91 & 75.22 & 4.67803 & 20.5 \\ \mathrm{H}-1,131 & 65.01 & 75.32 & 4.68290 & 20.5\end{array}$

$\begin{array}{lllll}8 \mathrm{H}-1,141 & 65.11 & 75.42 & 4.68776 & 20.6\end{array}$

$\begin{array}{lllll}8 \mathrm{H}-2,1 & 65.21 & 75.52 & 4.69263 & 20.5 \\ 8 \mathrm{H}-2,11 & 65.31 & 75.62 & 4.69749 & 20.6\end{array}$

\begin{tabular}{lllll}
$8 \mathrm{H}-2,21$ & 65.41 & 75.72 & 4.70236 & 20.5 \\
\hline
\end{tabular}

$\begin{array}{lllll}8 \mathrm{H}-2,31 & 65.51 & 75.82 & 4.70723 & 20.5 \\ 8 \mathrm{H}-2.41 & 65.61 & 75.92 & 4.71209 & 20.6\end{array}$

$\begin{array}{lllll}8 \mathrm{H}-2,51 & 65.71 & 76.02 & 4.71696 & 20.5\end{array}$

\begin{tabular}{lllll}
$8 \mathrm{H}-2,61$ & 65.81 & 76.12 & 4.72182 & 20.6 \\
\hline
\end{tabular}

$\begin{array}{lllll}8 \mathrm{H}-2,71 & 65.91 & 76.22 & 4.72669 & 20.5 \\ 8 \mathrm{H}-2,81 & 66.01 & 76.32 & 4.73156 & 20.5\end{array}$

$\begin{array}{lllll}\mathrm{H}-2,91 & 66.11 & 76.42 & 4.73642 & 20.6\end{array}$

\begin{tabular}{lllll}
$8 \mathrm{H}-2,101$ & 66.21 & 76.52 & 4.74129 & 20.5 \\
\hline
\end{tabular}

\begin{tabular}{lllll}
$8 \mathrm{H}-2,111$ & 66.31 & 76.62 & 4.74616 & 20.5 \\
\hline
\end{tabular}

$\begin{array}{lllll}8 \mathrm{H}-2,121 & 66.41 & 76.72 & 4.75102 & 20.6 \\ 8 \mathrm{H}-2,131 & 66.51 & 76.82 & 4.75589 & 20.5\end{array}$

$\begin{array}{lllll}8 \mathrm{H}-2,141 & 66.61 & 76.92 & 4.76075 & 20.6\end{array}$

$\begin{array}{lllll}8 \mathrm{H}-3,1 & 66.71 & 77.02 & 4.76562 & 20.5\end{array}$

$\begin{array}{lllll}8 \mathrm{H}-3,11 & 66.81 & 77.12 & 4.77059 & 20.1 \\ 8 \mathrm{H}-3,21 & 66.91 & 77.22 & 4.77646 & 17.0\end{array}$

$\begin{array}{lllll}8 \mathrm{H}-3,21 & 66.91 & 77.22 & 4.77646 & 17.0 \\ 8 \mathrm{H}-3,31 & 67.01 & 77.32 & 4.78234 & 17.0\end{array}$

$\begin{array}{lllll}\mathrm{H}-3,41 & 67.11 & 77.42 & 4.78822 & 17.0\end{array}$

$\begin{array}{lllll}8 \mathrm{H}-3,51 & 67.21 & 77.52 & 4.79409 & 17.0\end{array}$

$\begin{array}{lllll}8 \mathrm{H}-3,61 & 67.31 & 77.62 & 4.79997 & 17.0 \\ 8 \mathrm{H}-3,71 & 67.41 & 77.72 & 4.80585 & 17.0\end{array}$

$\begin{array}{lllll}8 \mathrm{H}-3,81 & 67.41 & 77.72 & 4.80585 & 17.0 \\ 8 \mathrm{H}-3,81 & 67.51 & 77.82 & 4.81172 & 17.0\end{array}$

$\begin{array}{lllll}8 \mathrm{H}-3,91 & 67.61 & 77.92 & 4.81760 & 17.0\end{array}$

$\begin{array}{lllll}8 \mathrm{H}-3,101 & 67.71 & 78.02 & 4.82347 & 17.0 \\ 8 \mathrm{H}-3,111 & 67.81 & 78.12 & 4.82935 & 17.0\end{array}$

$8 \mathrm{H}-3,121$

$\begin{array}{lll}67.91 & 78.22 & 4.82935 \\ 67.22 & 4.83523\end{array}$

17.0

$\begin{array}{ll}75.51 & 1.35 \\ 63.18 & 1.11 \\ 71.97 & 1.35 \\ 78.03 & 1.45 \\ 79.85 & 1.54 \\ 79.05 & 1.50 \\ 76.80 & 1.49 \\ 76.81 & 1.44 \\ 79.36 & 1.59 \\ 74.12 & 1.56 \\ 73.17 & 1.47 \\ 76.04 & 1.52 \\ 78.53 & 1.52 \\ 77.14 & 1.43 \\ 74.92 & 1.47 \\ 74.67 & 1.52 \\ 73.98 & 1.39 \\ 75.87 & 1.51 \\ 78.00 & 1.46 \\ 76.77 & 1.46 \\ 73.48 & 1.50 \\ 77.51 & 1.52 \\ 77.62 & 1.50 \\ 73.45 & 1.44 \\ 71.50 & 1.43 \\ 71.13 & 1.46 \\ 60.85 & 1.18 \\ 66.56 & 1.33 \\ 73.28 & 1.45 \\ 63.57 & 1.19 \\ 65.87 & 1.29 \\ 72.74 & 1.33 \\ 74.10 & 1.13 \\ 74.48 & 1.24 \\ 72.02 & 1.15 \\ 72.53 & 1.23 \\ 74.25 & 1.19 \\ 76.66 & 1.26 \\ 74.54 & 1.19 \\ 75.45 & 1.15 \\ 75.27 & 1.21 \\ 77.21 & 1.16 \\ 79.40 & 1.27\end{array}$

$\begin{array}{llr}0.858 & 3.01 & 5.80 \\ 0.858 & 2.33 & 7.17 \\ 0.912 & 2.04 & 7.00 \\ 0.905 & 4.72 & 5.10 \\ 0.940 & 5.52 & 4.20 \\ 0.926 & 7.85 & 4.70 \\ 0.940 & 6.37 & 4.47 \\ 0.912 & 6.89 & 4.43 \\ 0.976 & 5.94 & 4.00 \\ 1.026 & 2.70 & 4.83 \\ 0.976 & 1.99 & 5.77 \\ 0.969 & 2.58 & 5.40 \\ 0.940 & 6.66 & 4.07 \\ 0.905 & 6.33 & 4.20 \\ 0.955 & 5.74 & 5.40 \\ 0.993 & 4.13 & 5.97 \\ 0.912 & 2.03 & 7.33 \\ 0.969 & 3.43 & 6.90 \\ 0.912 & 4.73 & 5.73 \\ 0.926 & 4.55 & 4.13 \\ 0.997 & 3.14 & 6.20 \\ 0.955 & 3.30 & 6.60 \\ 0.940 & 3.74 & 6.37 \\ 0.955 & 4.19 & 7.60 \\ 0.969 & 3.98 & 11.53 \\ 0.997 & 2.99 & 19.50 \\ 0.947 & 1.63 & 40.10 \\ 0.969 & 2.43 & 20.40 \\ 0.962 & 4.75 & 10.53 \\ 0.912 & 3.44 & 18.80 \\ 0.955 & 2.61 & 6.90 \\ 0.912 & 2.81 & 10.77 \\ 0.898 & 4.31 & 8.10 \\ 0.976 & 3.30 & 6.83 \\ 0.940 & 3.19 & 7.07 \\ 0.997 & 2.93 & 7.10 \\ 0.940 & 4.52 & 6.70 \\ 0.969 & 6.55 & 5.40 \\ 0.940 & 5.06 & 6.10 \\ 0.898 & 4.97 & 5.90 \\ 0.940 & 4.29 & 5.87 \\ 0.883 & 5.92 & 5.50 \\ 0.940 & 7.66 & 4.43\end{array}$

Ash J, and below

Ash $\mathrm{K}$, and below

Ash $\mathrm{L}$, and below 


\begin{tabular}{|c|c|c|c|c|c|c|c|c|c|c|c|c|c|c|}
\hline $\begin{array}{l}\text { Core, section, } \\
\text { interval }(\mathrm{cm})\end{array}$ & $\begin{array}{l}\text { ODP } \\
\text { depth } \\
\text { (mbsf) }\end{array}$ & $\begin{array}{l}\text { Composite } \\
\text { depth } \\
\text { (m) }\end{array}$ & $\begin{array}{c}\text { Magnetic } \\
\text { age } \\
\text { (m.y.) }\end{array}$ & $\begin{array}{c}\text { Magnetic } \\
\text { sedimentation } \\
\text { rate } \\
(\mathrm{m} / \mathrm{m} . \mathrm{y} .)\end{array}$ & $\begin{array}{c}\delta^{18} \mathrm{O} \\
\text { age } \\
(\mathrm{m} . \mathrm{y} .)\end{array}$ & $\begin{array}{c}\delta^{18} \mathrm{O} \\
\text { sedimentation } \\
\text { rate } \\
(\mathrm{m} / \mathrm{m} . \mathrm{y} .)\end{array}$ & $\begin{array}{c}\text { Mean } \\
\left(\mathrm{wt} \% \mathrm{CaCO}_{3}\right)\end{array}$ & $\begin{array}{c}\text { Magnetic } \\
\mathrm{CaCO}_{3} \text { MAR } \\
\left(\mathrm{g} / \mathrm{cm}^{2} / \mathrm{k} . \mathrm{y} .\right)\end{array}$ & $\begin{array}{l}\delta^{13} \mathrm{C} \\
\%_{0} \text { to } \\
\text { (PDB) }\end{array}$ & $\begin{array}{l}\delta^{18} \mathrm{O} \\
\%_{0} \text { to } \\
\text { (PDB) }\end{array}$ & $\begin{array}{c}\begin{array}{c}\text { Dry-bulk } \\
\text { density } \\
\left(\mathrm{g} / \mathrm{cm}^{3}\right)\end{array}\end{array}$ & $\begin{array}{c}\text { Coarse } \\
\text { fraction } \\
\text { (wt } \%>150 \mu \mathrm{m})\end{array}$ & $\begin{array}{c}\text { Interpolated MS } \\
\text { K (10-6) } \\
\text { (cgs) }\end{array}$ & Comment \\
\hline \multicolumn{15}{|l|}{ 121-758A-(Cont.) } \\
\hline $8 \mathrm{H}-3,131$ & 68.01 & 78.32 & 4.84110 & 17.0 & & & 74.59 & 1.15 & & & 0.905 & 6.84 & 5.53 & \\
\hline $8 \mathrm{H}-3,141$ & 68.11 & 78.42 & 4.84698 & 17.0 & & & 69.72 & 1.00 & & & 0.841 & 3.73 & 8.70 & \\
\hline $8 \mathrm{H}-4,1$ & 68.21 & 78.52 & 4.85286 & 17.0 & & & 68.17 & 1.05 & & & 0.905 & 2.64 & 9.97 & \\
\hline $8 \mathrm{H}-4,11$ & 68.31 & 78.62 & 4.85873 & 17.0 & & & 69.03 & 1.09 & & & 0.926 & 3.48 & 10.43 & \\
\hline $8 \mathrm{H}-4,21$ & 68.41 & 78.72 & 4.86461 & 17.0 & & & 67.83 & 1.08 & & & 0.940 & 3.21 & 12.10 & \\
\hline $8 \mathrm{H}-4,31$ & 68.51 & 78.82 & 4.87049 & 17.0 & & & 71.19 & 1.13 & & & 0.933 & 3.81 & 9.20 & \\
\hline $8 \mathrm{H}-4,41$ & 68.61 & 78.92 & 4.87636 & 17.0 & & & 67.41 & 1.06 & & & 0.926 & 3.36 & 8.63 & \\
\hline $8 \mathrm{H}-4,51$ & 68.71 & 79.02 & 4.88224 & 17.0 & & & 72.49 & 1.23 & & & 0.997 & 3.74 & 8.20 & \\
\hline $8 \mathrm{H}-4,61$ & 68.81 & 79.12 & 4.88811 & 17.0 & & & 73.99 & 1.20 & & & 0.955 & 5.24 & 6.43 & \\
\hline $8 \mathrm{H}-4,71$ & 68.91 & 79.22 & 4.89399 & 17.0 & & & 75.15 & 1.24 & & & 0.969 & 4.46 & 6.73 & \\
\hline $8 \mathrm{H}-4,81$ & 69.01 & 79.32 & 4.89987 & 17.0 & & & 75.51 & 1.24 & & & 0.962 & 3.18 & 7.60 & \\
\hline $8 \mathrm{H}-4,91$ & 69.11 & 79.42 & 4.90574 & 17.0 & & & 71.07 & 1.23 & & & 1.012 & 1.96 & 9.23 & \\
\hline $8 \mathrm{H}-4,101$ & 69.21 & 79.52 & 4.91162 & 17.0 & & & 63.77 & 1.00 & & & 0.926 & 4.40 & 11.20 & \\
\hline $8 \mathrm{H}-4,111$ & 69.31 & 79.62 & 4.91750 & 17.0 & & & 72.55 & 1.13 & & & 0.912 & 4.19 & 7.10 & \\
\hline $8 \mathrm{H}-4,121$ & 69.41 & 79.72 & 4.92337 & 17.0 & & & 74.53 & 1.25 & & & 0.983 & 3.00 & 6.87 & \\
\hline $8 \mathrm{H}-4,131$ & 69.51 & 79.82 & 4.92925 & 17.0 & & & 72.34 & 1.11 & & & 0.905 & 2.80 & 6.43 & \\
\hline $8 \mathrm{H}-4,141$ & 69.61 & 79.92 & 4.93513 & 17.0 & & & 72.14 & 1.15 & & & 0.940 & 3.35 & 6.30 & \\
\hline $8 \mathrm{H}-5,1$ & 69.71 & 80.02 & 4.94100 & 17.0 & & & 73.30 & 1.17 & & & 0.940 & 2.96 & 6.33 & \\
\hline $8 \mathrm{H}-5,11$ & 69.81 & 80.12 & 4.94688 & 17.0 & & & 73.87 & 1.23 & & & 0.983 & 2.54 & 8.20 & \\
\hline $8 \mathrm{H}-5,21$ & 69.91 & 80.22 & 4.95276 & 17.0 & & & 72.12 & 1.17 & & & 0.955 & 3.02 & 8.10 & \\
\hline $8 \mathrm{H}-5,31$ & 70.01 & 80.32 & 4.95863 & 17.0 & & & 76.98 & 1.32 & & & 1.004 & 3.37 & 8.00 & \\
\hline $8 \mathrm{H}-5,41$ & 70.11 & 80.42 & 4.96451 & 17.0 & & & 77.08 & 1.23 & & & 0.940 & 4.01 & 6.50 & \\
\hline $8 \mathrm{H}-5,51$ & 70.21 & 80.52 & 4.97038 & 17.0 & & & 75.89 & 1.29 & & & 0.997 & 3.10 & 7.00 & \\
\hline $8 \mathrm{H}-5,61$ & 70.31 & 80.62 & 4.97626 & 17.0 & & & 75.89 & 1.32 & & & 1.026 & 2.83 & 6.97 & \\
\hline $8 \mathrm{H}-5,71$ & 70.41 & 80.72 & 4.98214 & 17.0 & & & 75.40 & 1.21 & & & 0.940 & 2.11 & 6.83 & \\
\hline $8 \mathrm{H}-5,81$ & 70.51 & 80.82 & 4.98801 & 17.0 & & & 77.10 & 1.19 & & & 0.905 & 3.48 & 5.90 & \\
\hline $8 \mathrm{H}-5,91$ & 70.61 & 80.92 & 4.99389 & 17.0 & & & 78.84 & 1.41 & & & 1.054 & 3.13 & 4.67 & \\
\hline $8 \mathrm{H}-5,101$ & 70.71 & 81.02 & 4.99977 & 17.0 & & & 76.22 & 1.27 & & & 0.983 & 2.46 & 5.37 & \\
\hline $8 \mathrm{H}-5,111$ & 70.81 & 81.12 & 5.00564 & 17.0 & & & 76.01 & 1.24 & & & 0.955 & 2.45 & 5.90 & \\
\hline $8 \mathrm{H}-5,121$ & 70.91 & 81.22 & 5.01152 & 17.0 & & & 71.69 & 1.16 & & & 0.955 & 1.06 & 6.83 & \\
\hline $8 \mathrm{H}-5,131$ & 71.01 & 81.32 & 5.01740 & 17.0 & & & 77.14 & 1.27 & & & 0.969 & 1.26 & 5.20 & \\
\hline $8 \mathrm{H}-6, \mathrm{I}$ & 71.21 & 81.52 & 5.02915 & 17.0 & & & 81.12 & 1.27 & & & 0.919 & 2.13 & 4.54 & \\
\hline $8 \mathrm{H}-6,11$ & 71.31 & 81.62 & 5.03503 & 17.0 & & & 79.23 & 1.26 & & & 0.933 & 1.58 & 5.67 & \\
\hline $8 \mathrm{H}-6,21$ & 71.41 & 81.72 & 5.04090 & 17.0 & & & 77.67 & 1.30 & & & 0.983 & 0.97 & 6.40 & \\
\hline $8 \mathrm{H}-6,31$ & 71.51 & 81.82 & 5.04678 & 17.0 & & & 80.77 & 1.28 & & & 0.933 & 1.82 & 5.10 & \\
\hline $8 \mathrm{H}-6,41$ & 71.61 & 81.92 & 5.05265 & 17.0 & & & 77.64 & 1.22 & & & 0.926 & 1.84 & 4.70 & \\
\hline $8 \mathrm{H}-6,51$ & 71.71 & 82.02 & 5.05853 & 17.0 & & & 77.15 & 1.27 & & & 0.969 & 2.08 & 5.20 & \\
\hline $8 \mathrm{H}-6,61$ & 71.81 & 82.12 & 5.06441 & 17.0 & & & 79.25 & 1.34 & & & 0.997 & 1.71 & 5.33 & \\
\hline $8 \mathrm{H}-6,71$ & 71.91 & 82.22 & 5.07028 & 17.0 & & & 79.24 & 1.33 & & & 0.983 & 1.03 & 5.90 & \\
\hline $8 \mathrm{H}-6,81$ & 72.01 & 82.32 & 5.07616 & 17.0 & & & 79.19 & 1.33 & & & 0.990 & 1.00 & 5.70 & \\
\hline $8 \mathrm{H}-6,91$ & 72.11 & 82.42 & 5.08204 & 17.0 & & & 77.79 & 1.21 & & & 0.912 & 1.09 & 5.67 & \\
\hline $8 \mathrm{H}-6,101$ & 72.21 & 82.52 & 5.08791 & 17.0 & & & 73.92 & 1.20 & & & 0.955 & 0.93 & 6.53 & \\
\hline $8 \mathrm{H}-6,111$ & 72.31 & 82.62 & 5.09379 & 17.0 & & & 73.58 & 1.12 & & & 0.898 & 1.11 & 6.50 & \\
\hline $8 \mathrm{H}-6,121$ & 72.41 & 82.72 & 5.09967 & 17.0 & & & 69.21 & 1.14 & & & 0.969 & 1.21 & 7.83 & \\
\hline $8 \mathrm{H}-6,131$ & 72.51 & 82.82 & 5.10554 & 17.0 & & & 64.42 & 1.07 & & & 0.976 & 1.02 & 10.30 & \\
\hline $8 \mathrm{H}-6,141$ & 72.61 & 82.92 & 5.11142 & 17.0 & & & 37.42 & 0.64 & & & 1.012 & 0.79 & 10.20 & Ash \\
\hline $8 \mathrm{H}-7,1$ & 72.71 & 83.02 & 5.11729 & 17.0 & & & 71.23 & 1.13 & & & 0.933 & 1.98 & 6.77 & \\
\hline $8 \mathrm{H}-7,11$ & 72.81 & 83.12 & 5.12317 & 17.0 & & & 75.18 & 1.15 & & & 0.898 & 2.36 & 6.93 & \\
\hline $8 \mathrm{H}-7,21$ & 72.91 & 83.22 & 5.12905 & 17.0 & & & 72.41 & 1.13 & & & 0.919 & 2.31 & 6.60 & \\
\hline $8 \mathrm{H}-7,31$ & 73.01 & 83.32 & 5.13492 & 17.0 & & & 65.99 & 1.11 & & & 0.983 & 1.16 & 7.10 & \\
\hline $8 \mathrm{H}-7,41$ & 73.11 & 83.42 & 5.14080 & 17.0 & & & 64.57 & 1.01 & & & 0.919 & 1.63 & 8.00 & \\
\hline
\end{tabular}


121-758B-

\begin{tabular}{|c|c|c|c|c|c|c|c|c|c|}
\hline $8 \mathrm{H}-5,11$ & 73.11 & 83.43 & 5.14139 & 16.9 & 70.06 & 1.13 & 0.947 & 2.18 & 7.80 \\
\hline $8 \mathrm{H}-5,21$ & 73.21 & 83.53 & 5.14726 & 17.0 & 72.97 & 1.20 & 0.969 & 2.49 & 7.40 \\
\hline $8 \mathrm{H}-5,31$ & 73.31 & 83.63 & 5.15314 & 17.0 & 72.85 & 1.17 & 0.947 & 3.47 & 7.43 \\
\hline $8 \mathrm{H}-5,41$ & 73.41 & 83.73 & 5.15902 & 17.0 & 71.61 & 1.09 & 0.898 & 3.66 & 8.87 \\
\hline $8 \mathrm{H}-5,51$ & 73.51 & 83.83 & 5.16489 & 17.0 & 62.22 & 1.04 & 0.983 & 1.62 & 12.10 \\
\hline $8 \mathrm{H}-5,61$ & 73.61 & 83.93 & 5.17077 & 17.0 & 74.82 & 1.20 & 0.940 & 1.35 & 6.07 \\
\hline $8 \mathrm{H}-5,71$ & 73.71 & 84.03 & 5.17665 & 17.0 & 79.03 & 1.34 & 0.997 & 2.84 & 5.53 \\
\hline $8 \mathrm{H}-5,81$ & 73.81 & 84.13 & 5.18252 & 17.0 & 78.64 & 1.30 & 0.969 & 3.02 & 4.70 \\
\hline
\end{tabular}

Note: Magnetic ages have been estimated to 5 decimal places to differentiate between closely spaced samples, not to reflect the accuracy of the age estimates. 